\title{
NATURAL SCIENCES AND MODERN TECHNOLOGICAL SOLUTIONS: KNOWLEDGE INTEGRATION IN THE XXI CENTURY
}

Collective monograph

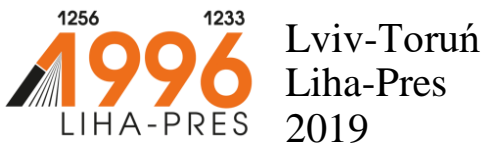




\section{Reviewers:}

Prof. nadzw., dr hab. Stanistaw Kunikowski, Rektor of Cuiavian University in Wloclawek (Republic of Poland);

Prof. $d r$ hab. Joanna Marszałek-Kawa, Uniwersytet Mikołaja Kopernika $w$ Toruniu / Nicolaus Copernicus University (Republic of Poland).

Natural sciences and modern technological solutions: knowledge integration in the XXI century : collective monograph / O. V. Averchev, H. S. Balashova, I. M. Biliaieva, S. P. Holoborodko, etc. - Lviv-Toruń : Liha-Pres, 2019. - 236 p.

ISBN 978-966-397-154-4

Liha-Pres is an international publishing house which belongs to the category "C" according to the classification of Research School for Socio-Economic and Natural Sciences of the Environment (SENSE) [isn: 3943, 1705, 1704, 1703, 1702, 1701; prefixMetCode: 978966397]. Official website www.sense.nl. 


\section{CONTENTS}

\section{CURRENT SITUATION AND PROSPECTS \\ OF CEREAL CROPS GROWING IN UKRAINE}

Averchev O. V.

THE INFLUENCE OF PHYSICAL CULTIVATION FACTORS

ON MICROCLONAL REPRODUCTION OF SANITIZED

IN THE CULTURE OF MERISTEMS IN VITRO PRIMARY

MATERIAL OF POTATO

Balashova H. S.

SYSTEMS OF BASIC TILLAGE IN THE CROP ROTATIONS

ON THE IRRIGATED LANDS OF SOUTHERN STEPPE

OF UKRAINE

Biliaieva I. M.

GLOBAL CHANGE IN CLIMATE AND ITS EFFECT

ON THE FORMATION OF CROPS IN SOUTHERN

TEPPE OF UKRAINE

Holoborodko S. P.

IRRIGATION - A KEY TOOL OF AGRICULTURAL

DEVELOPMENT AND MINIMIZATION OF THE EFFECT

OF CHANGES IN CLIMATE ON SOCIO-ECONOMIC

DEVELOPMENT OF UKRAINE

Hranovska L. M.

MODELING THE YIELD OF WINTER WHEAT AND CORN

TAKING INTO ACCOUNT HYDROTHERMAL FACTORS

IN THE CONDITIONS OF IRRIGATION OF THE SOUTH

OF UKRAINE

Kokovikhin S. V

BREEDING HERITAGE AND ITS ROLE IN STABILIZING PRODUCTION OF CORN GRAIN IN UKRAINE

Lavrynenko Yu. $\mathrm{O}$. 103 
WATER AND ENERGY SAVING TECHNOLOGIES OF TILLAGE IN THE CONDITIONS OF SOUTHERN ARID AND DRY STEPPE OF UKRAINE

Maliarchuk M. P. 120

INNOVATIVE ELEMENTS OF CULTIVATION TECHNOLOGY

OF CORN HYBRIDS OF DIFFERENT FAO GROUPS

IN THE CONDITIONS OF IRRIGATION

Marchenko T. Yu.

OPTIMIZATION OF CULTIVATION TECHNOLOGY

OF SUNFLOWER HYBRIDS IN THE CONDITIONS

OF THE SOUTH OF UKRAINE

Nesterchuk V. V

YEARLY AND OPERATION PLANNING

OF THE IRRIGATION REGIMES OF THE MAIN CROPS

Pysarenko P. V

PECULIARITIES OF THE IMPLEMENTATION

OF THE BASIN PRINCIPLE IN THE MANAGEMENT

OF WATER RESOURCES IN UKRAINE

Stashuk V. A.

SCIENTIFIC AND PRACTICAL ASPECTS OF THE FORMATION OF ECOLOGICALLY SAFE SYSTEMS OF IRRIGATED AGRICULTURE IN THE CONDITIONS OF THE SOUTH OF UKRAINE

Vozhegova R. A.

PHYTOSANITARY CONDITIONS OF WINTER CEREAL CROPS ON THE IRRIGATED LANDS OF THE SOUTH OF UKRAINE DEPENDING ON THE AGROMETEOROLOGICAL CONDITIONS OF THE YEAR

Zaiets S. O. 216 


\section{CURRENT SITUATION AND PROSPECTS OF CEREAL CROPS GROWING IN UKRAINE}

\section{Averchev O. V.}

\section{INTRODUCTION}

Under the auspices of the United Nations Food and Agriculture Organization (FAO), world leaders have adopted the agenda for Sustainable Development of Humanity until 2030, which was supported at the national level by Presidential Decree No. 722/2019 of 30.09.2019 «On Sustainable Development Goals of Ukraine for the period up to 2030 ». One of the primary goals of sustainable development is to eliminate the deficit of food, to recover from hunger, malnutrition and poverty. However, it is not only a duty to end hunger on the Earth, but also a complex and comprehensive concept that includes improving nutrition, achieving food security and improving sustainable development of agriculture and nutrition, sustainable use and management of natural resources, and the protection of genetic resources. The main goal of achieving food security for the population is to increase the yielding of cereal crops, which provide more than half of the daily calories that people need for their development and daily living activities ${ }^{1}$.

Increasing grain yielding is a strategically important task. However, it is known that there has not been a significant increase in the yield of cereal crops in recent years. In addition, the inefficient use of irrigated soils actualizes the problem of reducing the shortage of crop products. Therefore, at the present stage of resolving these issues is particularly acute.

To solve these complex problems, it is necessary to use new perspective cereal crops, their varieties (hybrids) with high genetic potential of productivity, and also to apply a complex of agrotechnical measures corresponding to the area of cultivation in each agro-ecological zone. Cereal crops are one of such prospects ${ }^{2}$.

The economic efficiency of cereal crops growing in southern Ukraine has not been sufficiently studied, and at the present stage, output of products

\footnotetext{
1 Постанова № 15/01 Президії національної академії аграрних наук України (протокол № 15 від 23 жовтня 2019 року).

2 Аверчев О.В. Організаційно - економічні аспекти інтенсифікації виробництва круп'яних культур. [навчальний посібник] / Аверчев О.В. - Херсон: ФОП Грінь Д.С., 2011.- 202 c.
} 
which requires less use of resources while maximizing use of potential of cultivated crops and regional features is a priority area.

The issues of increasing the economic efficiency of cereal crop yielding require further scientific justification and practical solution.

The status of problem study. Numerous scientific developments of such national scientists as V. Andriychuk, V. Boyko, P. Gaydutsky, P. Sabluk, O. Averchev and many others are devoted to studying various aspects of increasing the economic efficiency of crops growing, including cereal crops. However, the important aspects of improving yielding efficiency by improving cultivation technology, taking into account regional conditions, need more discussions. Solution of these questions will help to complement the theoretical, methodological and applied aspects of the formation of regional grain markets. This, in turn, will increase the level of application orientation of the problem and give the practice appropriate economic mechanism for the formation of market relations on the principles of supply and demand, restoring the competitiveness of grain yielding and the effective functioning of the market as a whole.

\section{Economic significance of cereal crops}

Agriculture has long become a business. In addition, the main task for farmers is to maximize profits by increasing revenues and reducing costs. Therefore, each agricultural crop is viewed through an economic prism, that is, how much money eventually can be obtained when it is grown on 1 ha.

Buckwheat, Panicum and rice are among the promising high-yielding cereal crops ${ }^{3}$.

In modern conditions of market relations, when the expediency of growing crops depends not only on the value of yield and quality of yielding, but also on demand, stable and high prices, buckwheat is one of the crops that can provide sustainable and high profits. Therefore, the most important task of agricultural production is to increase the buckwheat grain yielding ${ }^{4}$.

Buckwheat is a major cereal crop. Buckwheat has good taste, nutritional and dietary qualities and it is on first place according to the composition of the protein complex and nutritional value among other cereals. By physiological value, the buckwheat proteins are close to proteins of chicken eggs and milk. In the context of updating the issues of environmental yielding, it is important that the technological process of buckwheat growing

3 Постанова № 15/01 Президії національної академії аграрних наук України (протокол № 15 від 23 жовтня 2019 року).

4 Динаміка обсягів виробництва круп'яних культур в Херсонській області. / О.В. Аверчев, // Таврійський науковий вісник: збірник наукових праць. - Вип. 87. Херсон: Айлант, 2001. - С. 57-61. 
does not include the use of pesticides, which makes it possible to obtain completely environmentally friendly foodstuff.

The national economic importance of buckwheat is also lies in the fact that it is a valuable medicinal plant, one of the best honey plants, by-products of its production (chaff, straw) is a valuable feed in animal agriculture. Agrotechnical value of buckwheat is that it reduces the weediness of the fields, improves the physical properties of the soil, increases its fertility, and improves phytosanitary status. It is a good forecrop because it absorbs hard phosphorus and potassium compounds for self-feeding and leaves them in soil with plant residues. Buckwheat is also a replacement crop for the sowing of winter crops. In the southern region, it is grown in post-harvested sowings, as well as for green fodder and green fertilizer. Buckwheat intensively increases the green mass and can produce yields up to $20000 \mathrm{~kg} /$ ha in 50-60 days of vegetation. Buckwheat is a crop of waste-free growing technology ${ }^{5}$. In this regard, the problem of increasing the volume of buckwheat yielding in modern conditions is of particular importance.

Much attention is paid to the growing of buckwheat by farms that have constant orders from the producers of cereals, because it does not belong to the leading crops. This crop is considered as a valuable honey plant and a good forecrop to crop rotation for other crops.

Most farms grow buckwheat to support their own beekeeping, and grain is more commonly sold and processed in the region where it is grown. In areas where buckwheat sowings are located, buckwheat honey is a most popular kind of honey. The most characteristic is that every fourth part of the collected in CIS honey is buckwheat honey. One hectare of buckwheat sowing covers in general of 40-60 kg of honey, and under more favorable weather conditions $90-100 \mathrm{~kg}$, according to the Institute of Beekeeping. The importance of buckwheat as a honey plant is further enhanced by the fact that with the cultivation of fields, and most importantly with the development of new technologies, the honey flora is increasingly disappearing.

It is also used in fodder production, namely small grain, as well as offal, which are obtained during grain processing. Small, shrinked grain, as well as mill offal and flour dust, which are formed during the processing of grain, is used for feeding of livestock and poultry. Buckwheat chaff (50 feed units contains $100 \mathrm{~kg}$ of chaff) and silage from the green mass of buckwheat is a nutritious animal feed. Husk with the content of $40 \%$ of potassium oxide in

5 Аверчев О.В. Організаційно - економічні аспекти інтенсифікації виробництва круп'яних культур. [навчальний посібник] / Аверчев О.В. - Херсон: ФОП Грінь Д.С., 2011.- $202 \mathrm{c}$. 
ash remain during the processing of buckwheat at the peeling mills. It is used as valuable local potash manure and as raw material for potash production.

The most important argument in favor of the wide introduction of buckwheat to the agriculture in the Southern steppe of Ukraine is the resowing of buckwheat on irrigated areas. Buckwheat is one of the most promising crops for these purposes. A great reserve for increasing the yielding of this crop is resowing. The sowing area of the main crops has stabilized, and expanding the buckwheat and Panicum sowing areas at the expense of the spring-sown field is economically inexpedient.

It should be noted that buckwheat in economic terms is very profitable crop. With the yield of 500-700 kg / ha, all costs for its growing are paid off, and with the yield of $1500-2000 \mathrm{~kg} / \mathrm{ha}$, buckwheat becomes the most profitable crop. Moreover, the greater the area of its sowing is, the higher profitability of buckwheat is.

Earlier, buckwheat was considered a strategically important food product that had an impact on food security in the country. In recent years, many alternative types of cereals that can replace buckwheat have appeared in the domestic market of Ukraine, which is why this type of product affects the general food situation in the country. Price controls the level of consumption. So now, there is the following price situation: buckwheat costs $10 \%$ more than rice $^{6}$.

Consumer basket in Ukraine is calculated in such a way that consumption of buckwheat per year is $2 \mathrm{~kg} /$ person, of rice $-2.5 \mathrm{~kg} /$ person, and of Panicum it is $1 \mathrm{~kg} /$ person. In comparison with the European countries (Poland), the consumption of buckwheat is $75 \%$ and of rice is $65 \%$ lower than in Ukraine ${ }^{7}$.

Rice is the most important, most productive, most ancient and most caloric crop among all the cereals. It is grown on all continents of the world. The largest areas are given to rice, as to wheat and maize. The area of rice sowing has tripled in the last 100 years and now amounts to more than 150 million hectares. Rice has a higher potential yield compared to wheat of $800-1000 \mathrm{~kg} / \mathrm{ha}$, which provides an annual gross yield of almost 600 million tons. There are about 30 species of rice, but common rice (O. Sativa) is the most widespread. It is an annual plant with a height of $50-200 \mathrm{~cm}$, in Ukraine $-80-140 \mathrm{~cm}$.

${ }^{6}$ Аверчев О.В. Організаційно - економічні аспекти інтенсифікації виробництва круп'яних культур. [навчальний посібник] / Аверчев О.В. - Херсон: ФОП Грінь Д.С., 2011.- $202 \mathrm{c}$.

7 Динаміка обсягів виробництва круп'яних культур в Херсонській області. / О.В. Аверчев, // Таврійський науковий вісник: збірник наукових праць. - Вип. 87. Херсон: Айлант, 2001. - С. 57-61. 
The rice systems are located near the sea coasts and are in close proximity to the resort areas not only in Ukraine, but in most rice sowing countries of the world. In the early years, the technology of rice cultivation did not meet the requirements of ensuring ecological balance. Therefore, the scientists of the Institute of Rice of the National Academy of Agrarian Sciences of Ukraine (NAAS) carried out the important research and created a new environmentally friendly technology, taking into account all the requirements of environmental protection, which received positive conclusions of state expertise. The experience of the Rice Institute on addressing environmental issues has attracted the attention of foreign colleagues.

The main task of modern agricultural productivity, including rice yielding, is to obtain a high economically viable grain yield, which is largely facilitated by the cultivar. Rice growing as an intensive industry requires new varieties with high productivity, adapted to biotic and abiotic environmental factors, which in different agro-ecological conditions could give maximum profit ${ }^{8}$.

Nowadays, such valuable cereal crop as the Panicum are receiving insufficient attention, although it is characterized by high drought tolerance, which is quite positive with the gradual change of the climate over the last decade. And this crop, unlike buckwheat, provides fairly stable yields on the South Ukraine area, regardless of weather conditions ${ }^{9}$.

Panicum is one of the major crops in the world. This spring cereal is appreciated for its high taste qualities of the grain (millet). It is resistant to drought, it is a crop of short daylight, has a fast growing season. Due to these properties, it is often sown as a nutrimental.

However, Panicum has never held a leading role among crops in the agricultural sector of Ukraine. It is one of the major cereals of Ukraine, the value of which is determined by the almost waste-free use of processing products in the food, feed, pharmaceutical and microbiological industries, as well as the by the possibility of growing in post-harvested sowings, which ensures two yields and increase the yield per hectare. Unprocessed Panicum is used as a very valuable animal feed. The by-products that are received during the processing of grain into groats (flour, husk) are also feed. Straw and chaff are close to meadow hay by their qualities. Panicum is widely used as a replacement crop in the event of resowing of fallen winter and early spring crops, which is especially important for yield formation and income during a year. Panicum consist of $12 \%$ of

${ }^{8}$ Динаміка обсягів виробництва круп'яних культур в Херсонській області. / О.В. Аверчев, // Таврійський науковий вісник: збірник наукових праць. - Вип. 87. - Херсон: Айлант, 2001. - С. 57-61.

9 Кернасюк Ю.В. Зернові культури: тенденції і прогнози ринку / Агробізнес сьогодні. - 2017 р. - № 17(360) - С. 12-19. 
protein, $81 \%$ of starch, $3.5 \%$ of fat and $1-2 \%$ of fiber. The grain is rich with minerals, micro-elements, vitamins B1, B2, B5, B6, C, carotenoids and other physiologically active elements. Also, the crop contains a large amount of starch, so it is used for the production of alcohol ${ }^{10}$.

The underestimation of the value of Panicum growing is erroneous. Panicum is a high-yielding cereal crop. By adhering to the technology of growing, it yields grains over $5000 \mathrm{~kg} / \mathrm{ha}$. Yields are often higher than other cereals.

\section{Dynamics of cereal crops growing in Ukraine}

According to the State Statistics Service of Ukraine, the area of cereal crops during the research period was undulating, except for rice sowings, which is related to the specificity of the technology of the crop growing (Table 1).

Table 1

Yielding of buckwheat, Panicum and rice in Ukraine for 2015-2018

\begin{tabular}{|c|c|c|c|}
\hline Crop & $\begin{array}{c}\text { Harvested area, } \\
\text { tons of ha }\end{array}$ & $\begin{array}{l}\text { Gross output in weight after } \\
\text { processing, thousand tons }\end{array}$ & $\begin{array}{c}\text { Yield, } \\
\text { kg per ha }\end{array}$ \\
\hline \multicolumn{4}{|c|}{2015} \\
\hline Buckwheat & 127,7 & 128,1 & 1000 \\
\hline Panicum & 112,8 & 213,2 & 1890 \\
\hline Rice & 11,7 & 62,5 & 5340 \\
\hline \multicolumn{4}{|c|}{2016} \\
\hline Buckwheat & 153,7 & 176,4 & 1150 \\
\hline Panicum & 107,7 & 189,7 & 1760 \\
\hline Rice & 12,0 & 64,7 & 5390 \\
\hline \multicolumn{4}{|c|}{2017} \\
\hline Buckwheat & 185,3 & 180,4 & 970 \\
\hline Panicum & 56,1 & 84,4 & 1500 \\
\hline Rice & 12,7 & 63,9 & 5050 \\
\hline \multicolumn{4}{|c|}{2018} \\
\hline Buckwheat & 113,3 & 137,0 & 1260 \\
\hline Panicum & 54,8 & 80,5 & 1460 \\
\hline Rice & 12,6 & 69,2 & 5490 \\
\hline
\end{tabular}

Buckwheat occupies the largest areas among the major studied cereal crops. Buckwheat crop area was larger than the harvested area of Panicum from $11.7 \%$ in 2015 to $70 \%$ in 2017 and larger than the sowing area of rice from $109.2 \%$ in 2015 to $106.9 \%$ in 2017.

10 Аверчев О.В. Організаційно - економічні аспекти інтенсифікації виробництва круп'яних культур. [навчальний посібник] / Аверчев О.В. - Херсон: ФОП Грінь Д.С., 2011.- 202 c. 
Rice crop areas have remained virtually unchanged over the years as they are linked to the check system of growing, and rice growing under drip irrigation is only gaining momentum. Gross output after processing during 2015 and 2016 was the highest during Panicum growing and amounted to 213.2 thousand tons and 189.7 thousand tons respectively, which is $70.7 \%$ more than the gross output of rice after processing in 2015 and $66.3 \%$ more in 2016.

Due to the sharply reduced sowing area by $49.9 \%$ in 2017 and $48.6 \%$ in 2018 compared to 2015, the large difference in gross output in weight after processing between rice and Panicum was practically leveled. The gross output of Panicum was the highest for all years of research in 2015 and 2016 and in the same years, it was the highest among all the studied crops. From 2017, the maximum gross output was received from buckwheat growing at 137.0 thousand tons in 2018 and 180.4 thousand tons in 2018. Among the studied cereal crops, traditionally the most productive is rice that is connected with its biological potential. The maximum yield of rice was obtained in 2018 at the level of $5490 \mathrm{~kg} / \mathrm{ha}$, which is 3.7 times higher than the average Panicum yield and 4.4 times higher than the average buckwheat yield in Ukraine.

According to official statistics, the buckwheat harvested area in Ukraine in 2018 decreased, depending on the studied year from 14.4 thousand hectares to 72 thousand hectares. The maximum area of sowings which was harvested was in 2018. At the same time, the average yield increased by $290 \mathrm{~kg} / \mathrm{ha}$ and amounted to $1260 \mathrm{~kg} / \mathrm{ha}$, the gross output exceeded 137.0 thousand tons, which is more than in 2015 by $7.0 \%$.

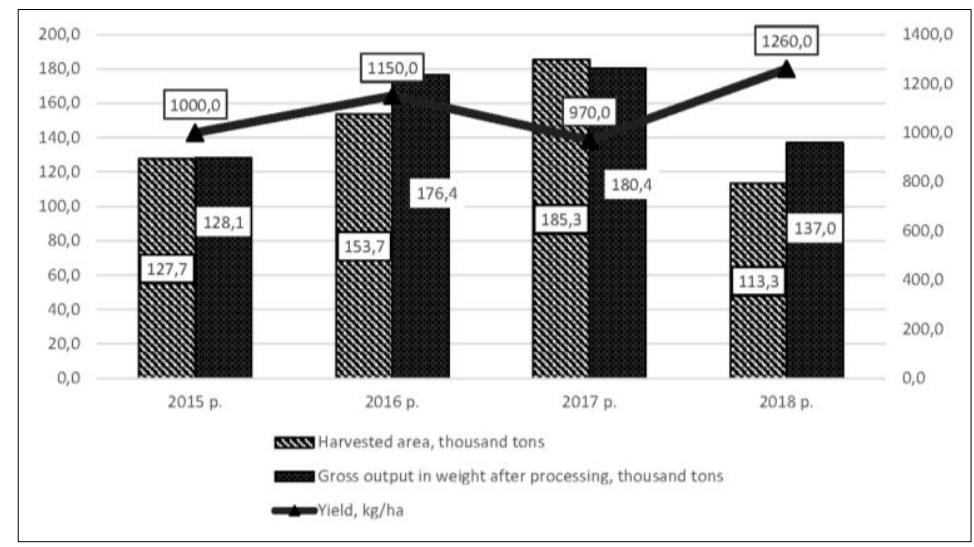

Fig. 1. Indicators of buckwheat yielding in Ukraine 
The dynamics of buckwheat grain yielding in Ukraine can be described as undulating. The main reasons for the decrease in the gross output of buckwheat are unfavorable climatic conditions (drought), high costs for its growing relative to other crops, non-compliance of agro-technology and lack of financial investments in crop growing and, as a consequence, decrease of its productivity. Thus, the largest gross output of buckwheat in mass after processing reached in 2017 and amounted to 180.4 thousand tons.

It should be noted that Ukraine is on the third place in the world for buckwheat growing (9\%) after China (39\%) and Russia $(22 \%)^{11}$.

The situation is better with rice. The harvested area in 2018 was 12.6 thousand hectares, which is more by 0.6 thousand hectares in 2016 and by 0.9 thousand hectares in 2015. At the same time, the yield increased by $490 \mathrm{~kg} / \mathrm{ha}$ in comparison with 2017 and is $5490 \mathrm{~kg} / \mathrm{ha}$ at a gross output of 69.2 thousand tons. (Fig. 3).

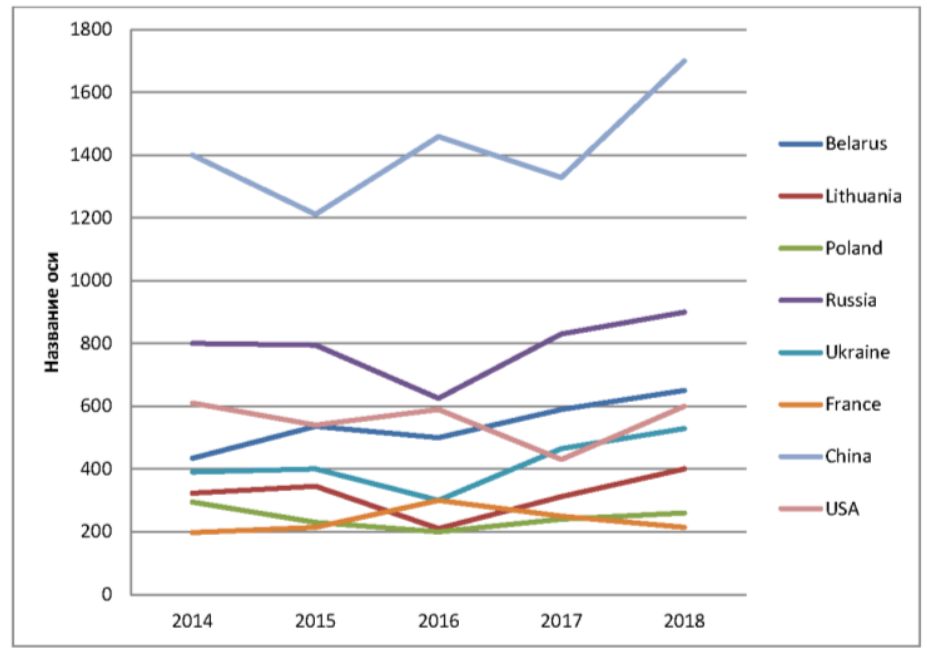

Fig 2. The main producers of buckwheat in the world

11 Кернасюк Ю.В. Зернові культури: тенденції і прогнози ринку / Агробізнес сьогодні. - 2017 р. - № 17(360) - С. 12-19. 


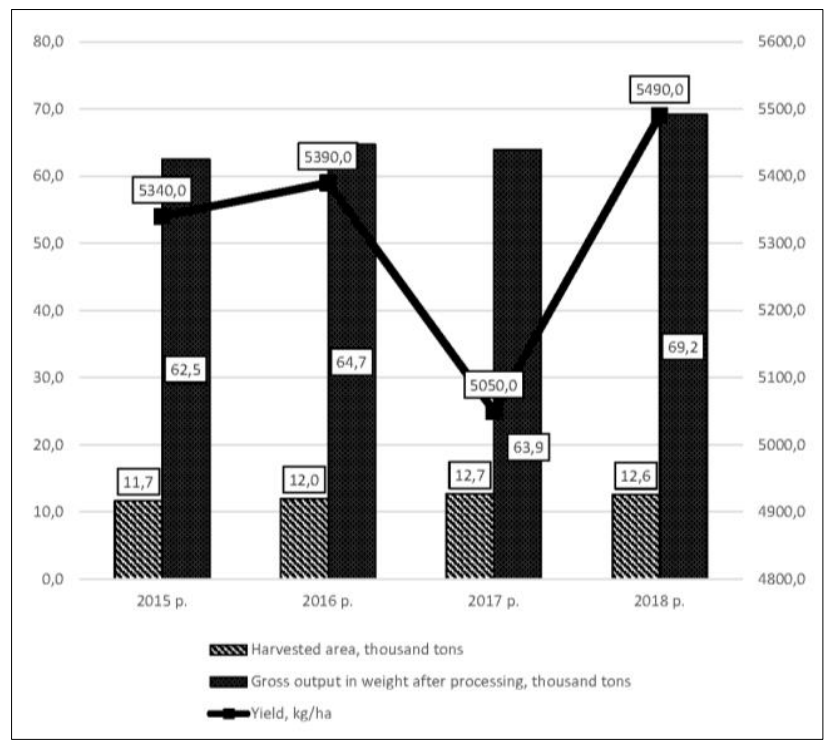

Fig. 3. Indicators of rice yielding in Ukraine

Rice, along with buckwheat, is the leader of cereals consumption among the population of Ukraine. The overall level of domestic rice yielding accounts for only $35 \%$ of the market's needs, so this market is now importdependent (Fig. 4). As a result of rice imports, there was a significant increase in 2014, amounting to 84.0 thousand tons. And the lowest exports in 2015-2016 was 43980 thousand tons. The average export value in relation to 2016/17 is 45790 thousand tons. Analyzing, it is seen that rice imports have unstable indicators. The largest importers are India, Pakistan, Kazakhstan, and Vietnam.

Although by 2014, the situation was somewhat different: rice checks located in the Crimea made it possible to grow a larger share of what was needed on the territory of the country.

In 2018, Ukrainian agrarians harvested 80.5 thousand tons of Panicum, which is $4.6 \%$ less than in the previous year (Table 4). In particular, agricultural enterprises harvested 52.0 thousand tons of Panicum, which is $5.9 \%$ more than in 2017, and households harvested 28.5 thousand tons $(-20.2 \%)$. 
Table 2

Rice import to Ukraine

\begin{tabular}{|c|c|c|c|}
\hline $\begin{array}{c}\mathbf{2 0 1 4} \\
\text { 84 thousand tons }\end{array}$ & $\begin{array}{c}\mathbf{2 0 1 5 / 2 0 1 6} \\
\mathbf{4 3} 980 \text { thousand } \\
\text { tons }\end{array}$ & $\begin{array}{c}\mathbf{2 0 1 6 / 2 0 1 7} \\
\mathbf{4 5} \mathbf{7 9 0} \text { thousand } \\
\text { tons }\end{array}$ & $\begin{array}{c}\mathbf{2 0 1 7 / 2 0 1 8} \\
\mathbf{5 3 ~ 4 5 6} \\
\text { thousand tons }\end{array}$ \\
\hline India $32450 \mathrm{t}$ & $\begin{array}{c}\text { India } 16345 \\
\mathrm{t}, 43,3 \%\end{array}$ & $\begin{array}{c}\text { India } 16426 \\
\mathrm{t}, 35,9 \%\end{array}$ & India \\
\hline Pakistan $21569 \mathrm{t}$ & $\begin{array}{c}\text { Pakistan } 13245 \\
\mathrm{t}, 35,5 \%\end{array}$ & $\begin{array}{c}\text { Pakistan } 14626 \\
\mathrm{t}, 31,9 \%\end{array}$ & Pakistan \\
\hline Vietnam $13450 \mathrm{t}$ & $\begin{array}{c}\text { Kazakhstan } 5900 \\
\mathrm{t}, 9,5 \%\end{array}$ & $\begin{array}{c}\text { Kazakhstan } 6052 \\
\mathrm{t}, 13,2 \%\end{array}$ & Kazakhstan \\
\hline & $\begin{array}{c}\text { Thailand } 4320 \\
\mathrm{t}, 3,9 \%\end{array}$ & $\begin{array}{c}\text { Vietnam } 4449 \\
\mathrm{t}, 9,7 \%\end{array}$ & Thailand \\
\hline & $\begin{array}{c}\text { Vietnam } 2100 \\
\mathrm{t}, 3,5 \%\end{array}$ & $\begin{array}{c}\text { Thailand } 2174 \\
\mathrm{t}, 4,7 \%\end{array}$ & \\
\hline & Russia $809 \mathrm{t}, 1,6 \%$ & Russia $899 \mathrm{t}, 2,0 \%$ & \\
\hline & Italy $435 \mathrm{t}, 1,3 \%$ & Italy $535 \mathrm{t}, 1,2 \%$ & \\
\hline & & USA $440 \mathrm{t}, 1,0 \%$ & \\
\hline
\end{tabular}

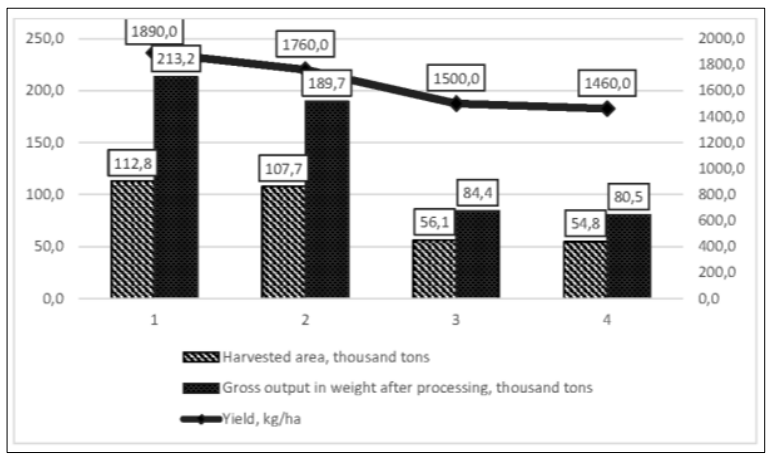

Fig. 4. Indicators of Panicum yielding in Ukraine

The decrease in the volume of Panicum yielding is due to both the reduction of acreage under it and the decrease in the average crop yield. Last year, 54.8 thousand hectares were sown with Panicum, which is $2.3 \%$ less than in 2017. The average yield decreased by $2.7 \%$ and amounted to $1460 \mathrm{~kg} / \mathrm{ha}$.

It should be noted that the Panicum yielding in Ukraine (for 2005-2018 $1260 \mathrm{~kg} / \mathrm{ha})$ significantly exceeds the world average yielding $(850 \mathrm{~kg} / \mathrm{ha})$ of 
this grain, as well as the yielding in India $(91 \mathrm{~kg} / \mathrm{ha})$ - the world leader of Panicum yielding ${ }^{12}$.

The structure of domestic consumption of Panicum consists of $20 \%$ of food and $72 \%$ fodder use of it.

According to the estimates of grain market experts, it is planned to reduce the area under buckwheat in Ukraine, because buckwheat growing technology provides certain specific features. It is necessary to take into account the norms of buckwheat sowings, biology of nutrition, growth and flowering for high yields. That is why it was given the status of a capricious crop.

In total, there are currently 30000 ha of rice irrigation systems in Ukraine. In recent years, rice has been sown on an area of about 13000 hectares, and when restoring such systems, especially in the Odessa region, it is possible to increase the area under rice by another 2000 hectares. The general climatic conditions and water resources of Ukraine allow growing rice on an area of more than 100000 hectares.

Experts say that at this stage it is necessary to increase the area of rice crops. The culture itself is not easy to grow; it requires a special climate heat and humidity. In Ukraine, farmers buy seeds at the only rice institute in Ukraine (Antonovka village, Skadovsk).

Rice cereals of domestic production are made exclusively from grown grain, since there are no state stocks of rice in Ukraine. It contains the required range of valuable indicators of quality, which is not inferior to the imported ones, but far exceeds them by some, including culinary ones. However, under market conditions, it has to be equated with price of lowcalorie crop. The cheapest third-grade cereals produced from the grain of state stocks of exporting countries after long-term storage or from its mixture with freshly-produced grain come from abroad to Ukraine in large quantities. Quality of such grain is much worse than quality of domestic grain, both in terms of biochemical parameters, look and smell, but due to the cheap and low purchasing power of the population, it dictates a general decrease in prices in the market ${ }^{13}$.

Growing of cereal crops is concentrated in certain regions of Ukraine, where the climatic conditions, soil composition, etc. are the best for them.

In Ukraine, the forest-steppe and Polissya zones are the most favorable for the buckwheat growing, where natural and climatic conditions allow protecting crops from arid winds, which allows plants to grow better during vegetation and have higher yields.

Soils and conditions of other regions are also suitable for growing buckwheat, but because of low yields the sowing areas of this crop are insignificant. According to the results of 2018, the largest gross buckwheat

\footnotetext{
12 Офіційний сайт Держкомстату України [Електронний ресурс]. - Режим доступу : http://www.ukrstat.gov.ua/

13 Динаміка обсягів виробництва круп'яних культур в Херсонській області. / О.В. Аверчев, // Таврійський науковий вісник: збірник наукових праць. - Вип. 87. Херсон: Айлант, 2001. - С. 57-61.
} 
harvests were received in Zhytomyr (28.0 thousand tons), Khmelnitsky (18.6 thousand tons), Sumy (11.6 thousand tons), Kyiv (10.7 thousand tons), Kharkiv (10.4 thousand tons) and Vinnitsa (10.1 thousand tons) oblasts. Transcarpathian farmers $(1920 \mathrm{~kg} / \mathrm{ha})$, Kyiv and Khmelnytskyi $(1560 \mathrm{~kg} / \mathrm{ha})$ received the highest yields. For comparison, the yield of this crop in the Kherson region is $980 \mathrm{~kg} / \mathrm{ha}$ with a gross output of 0.5 thousand tons.

About $52.0 \%$ of the sowing areas of Panicum are concentrated in the Southern region (Zaporizhzhya, Kherson, Mykolaiv, Dnipropetrovsk and Odessa regions), the main producers of this crop are Kharkiv (12.6\%), Zaporizhzhia (10.9\%), Dnipropetrovsk and Donetsk (9.5\%), Mykolaiv $(9.0 \%)$ regions. The highest average annual yield indicators have Cherkasy (2350 kg/ha), Poltava (2280 kg/ha), Kharkiv (2010 kg/ha), Vinnytsia (1910 kg/ha) and Lviv (1900 kg/ha). Buckwheat crops are mainly located in 10 regions of the North, West and Central regions) $-75.3 \%$ of the total area, $48.8 \%$ of which are the farms of Sumy, Khmelnytsky, Kharkiv, Vinnytsia and Chernihiv regions. The main producers of this crop are: Khmelnytskyi $12.9 \%$, Sumy $-12.8 \%$, Kharkiv $-10.2 \%$, Vinnytsia $-9.0 \%$ and Kiev oblast $-8.2 \%$, and the highest average annual buckwheat yield indicators have Kyiv (1260 kg/ha), Vinnytsia (1100 kg/ha), Kharkiv (1090 kg/ha), Khmelnitsky (1040 kg/ha), Sumy and Cherkasy (1020 kg/ha) 3. Therefore, those regions that have larger areas are not always the largest producers of cereals (rice, Panicum and buckwheat) and the highest average annual yield indicators doesn't have farms where larger areas occupied by the crop, which means that the structure of sowings areas, production and yields do not match, although these indicators are interdependent.

\section{CONCLUSIONS}

Analysis of the dynamics of buckwheat, Panicum and rice growing in Ukraine showed that the situation is not stable. Sowings areas of cereal crops during the study period were undulating, except for rice crop that is related to the specificity of cultivation technology. A similar situation was observed in the analysis of yielding of the studied crops, which in turn was reflected in the gross output of crops.

Experts estimate that the low level of economic efficiency of the industry was the result of a number of factors, including deterioration of socio-economic conditions of the farms, lack of a state program of development and support of cereal crops growing, insufficient provision of means of growing and in this regard, non-compliance of the requirements of the technology of crops growing, and also increase of production prime cost (increase of prices for pesticides, mineral fertilizers, fuel and lubricants, seeds, etc.).

In order to obtain high and sustainable yields of buckwheat, Panicum and rice and increase economic efficiency, it is recommended to introduce not only the latest growing technologies, but also to deepen specialization, concentration of cereal crops growing and to develop ways of improving the 
economic relations between enterprises of the production and processing of grain of cereal crops.

The problems of development of the grain economy and the market of cereal crops can be solved on the basis of the relevant law of Ukraine, according to which the state restores the contract system for grain in terms of rational needs and strategic stocks, implements the mechanism of intervention procurement, and creates the appropriate infrastructure in the grain market. Under this scheme, the State Directorate for Production and Sale of Grain and Grain Processing, subordinated to the Government, should be established in Ukraine, the activity of which will be controlled by representatives of producers and organizations within its administrative council.

\section{SUMMARY}

The economic efficiency of cereal crops growing in southern Ukraine has not been sufficiently studied, and at the present stage, a priority area in crop growing is yielding of grain, which requires less use of resources while maximizing use of the potential of grown crops and regional features.

The article deals with the dynamics of growing of buckwheat, Panicum and rice. It is established that among studied crops buckwheat occupies the largest areas. Buckwheat crop area was larger than the harvested area of Panicum from $11.7 \%$ in 2015 to $70 \%$ in 2017 and larger than the sowing area of rice from $109.2 \%$ in 2015 to $106.9 \%$ in 2017.

Gross output in weight after processing during 2015 and 2016 was the highest during Panicum growing and amounted to 213.2 thousand tons and 189.7 thousand tons respectively, which is $70.7 \%$ more than the gross output of rice after processing in 2015 and $66.3 \%$ more in 2016.

Due to the sharply reduced sowing area by $49.9 \%$ in 2017 and $48.6 \%$ in 2018 compared to 2015, the large difference in gross output in weight after processing between rice and Panicum was practically leveled. The gross output of Panicum was the highest for all years of research in 2015 and 2016 and in the same years, it was the highest among all the studied crops. From 2017, the maximum gross output was received from buckwheat growing at 137.0 thousand tons in 2018 and 180.4 thousand tons in 2018. Among the studied cereal crops, traditionally the most productive is rice that is connected with its biological potential. The maximum yield of rice was obtained in 2018 at the level of $5490 \mathrm{~kg} / \mathrm{ha}$, which is 3.7 times higher than the average Panicum yield and 4.4 times higher than the average buckwheat yield in Ukraine.

\section{REFERENCES}

1. Постанова № 15/01 Президії національної академії аграрних наук України (протокол № 15 від 23 жовтня 2019 року).

2. Аверчев О.В. Організаційно - економічні аспекти інтенсифікації виробництва круп'яних культур. [навчальний посібник] / Аверчев О.В. Херсон: ФОП Грінь Д.С., 2011.- 202 с. 
3. Динаміка обсягів виробництва круп'яних культур в Херсонській області. / О.В. Аверчев, // Таврійський науковий вісник: збірник наукових праць. - Вип. 87. - Херсон: Айлант, 2001. - С. 57-61.

4. Сільське господарство України у 2017 р.: Статистичний збірник К.: Державна служба статистики України, Статистичний збірник.

5. Сільське господарство України у 2018 р.: Статистичний збірник К.: Державна служба статистики України, Статистичний збірник

6. Сільське господарство України у 2019 р.: Статистичний збірник К.: Державна служба статистики України, Статистичний збірник

7. https://graintrade.com.ua/ru/novosti/zakupivelni-tcini-na-zernov-ukraini-na-14-veresnya-2018-roku.html

8. Офіційний сайт Держкомстату України [Електронний ресурс]. Режим доступу : http://www.ukrstat.gov.ua/

9. Кернасюк Ю.В. Зернові культури: тенденції і прогнози ринку / Агробізнес сьогодні. - 2017 р. - № 17(360) - С. 12-19.

\section{Information about the author:} Averchev O. V.,

Doctor of Agricultural Science, Professor, Prorector for Scientific Work and International Activity, State Higher Educational Institution "Kherson State Agricultural University" 23, Stritenskaya str., Kherson, Ukraine 


\section{THE INFLUENCE OF PHYSICAL CULTIVATION FACTORS ON MICROCLONAL REPRODUCTION OF SANITIZED IN THE CULTURE OF MERISTEMS IN VITRO PRIMARY MATERIAL OF POTATO}

\section{Balashova H. S.}

\section{INTRODUCTION}

For a long time, seed growing of potato was based on the selection of healthy plants in general plantings. Clonal, bush, cluster, tuberous and a negative selection with the assessment of the material selected for the presence of viral infection were used.

A feature of modern seed growing of potato is the use for reproduction of the elite primary material, sanitized by methods of active treatment of contaminated potato varieties: by thermotherapy and meristem tissue culture, in combination with microclonal reproduction, which is intended to provide a disease-free primary material of potato in the volumes sufficient for the first links of seed growing ${ }^{1,2,3}$.

By changing the environmental factors in the cultivation of plants in vitro under controlled conditions on artificial nutrient media, it is possible to regulate the process of organogenesis, in particular to induce the formation of tubers. This process is influenced by the varietal characteristics of plants: most varieties (95\%) form micro tubers in 55-60 days, in others - the tuber formation lasts for a longer period. This process can be accelerated by the optimal interaction of the main factors that stimulate it: the content of carbohydrates and biologically active substances in the nutrient medium, the values of the photoperiod and temperature ${ }^{4}$.

For the induction of microtubers in plants in vitro, a number of factors are used: mineral-enriched medium, higher sugar (4-8\%) and kinetin (up to $1 \mathrm{mg} / \mathrm{l}$ ) content, reduced photoperiod at a certain stage of plant growth, biologically active substances. The optimal ratio of these factors allows to obtain microtubers of full value with a diameter of $7-8 \mathrm{~mm}$ in $80-85 \%$ of planted culm segments.

\footnotetext{
${ }^{1}$ Бугаєва І. П., Сніговий В. С. Культура картоплі на півдні України : монографія. Херсон, 2002. $176 \mathrm{c}$.

${ }^{2}$ Коновалова Г. И., Бобрик А. О., Семенова 3. А. Производство исходного семенного материала. Картофелеводство: науч. тр. БНИИКХ, 2000. Вып. 10. С. 215-221.

${ }^{3}$ Cassels A. C. In vitro induction of virus - free potatoes by chemotherapy. Biotechnology in Agriculture and Forestry (3). Potato. Berlin, 1987. P. 40-50.

${ }_{4}$ Бондарчук А. А. Наукові основи насінництва картоплі в Україні : монографія. Біла Церква, 2010. 400 c.
} 
Taking into account the considerable cost of in vitro-derived seed material, the improvement of micro-reproduction techniques of the sanitized material is of particular relevance5. Therefore, a number of experiments were conducted at the Institute of Irrigated Agriculture of NAAS with the aim of developing new and improving existing ways and methods for the intensification of the process of microclonal reproduction of healthy primary material in the culture of meristems in vitro ${ }^{6}$.

\section{Tuberization of potato in vitro at different light intensities and cultivation temperatures}

Light intensity and temperature are considered to be among the most important factors in the growing of microtubers in vitro. The Potato Biotechnology Laboratory of the Institute of Irrigated Agriculture of NAAS conducted a research considering the ratio of temperature and light intensity on the growth, development and productivity of plants of early-ripening potato variety $\mathrm{Kobza}^{7}$. Plants in vitro were grown at temperature conditions $14-16 ; 20-22 ; 24-26^{\circ} \mathrm{C}$ and lighting 500; 1500; 2000; 3000 lux (further lx).

The results of the studies showed a direct correlation of plant height in vitro with temperature. So, on the 20th day of observation, this index at a temperature of $24-26^{\circ} \mathrm{C}$ was higher, on average, by $2.7 \mathrm{~cm}$ than at a temperature of $14-16^{\circ} \mathrm{C}$ and by $0.5 \mathrm{~cm}$ than at $20-22^{\circ} \mathrm{C}$ (Table 1 ).

On the day 40 of the observations, this dependence was maintained and the difference was 3.8 and $1.5 \mathrm{~cm}$, respectively. Besides, in vitro plants grown at an illumination intensity of $1500 \mathrm{~lx}$ were $9.4 \%$ higher than in the illumination of $500 \mathrm{~lx}$ and 26.0 and $22.8 \%$, respectively, than in 2000 and $3000 \mathrm{~lx}$.

As the temperature of cultivation increased, the formation of stolons by plants was inhibited. On the 20th day of the observation, the number of plants that formed stolons at a temperature of $24-26^{\circ} \mathrm{C}$, on average, was by 30.2 and 21.4 relative percent less than at a temperature of 14-16 and 20$22^{\circ} \mathrm{C}$, respectively. Microtubers on the 20th day of the observation were formed at $7.3 ; 8.7$ and $2.0 \%$ of plants, respectively, according to the growing temperatures of $14-16,20-22$ and $24-26^{\circ} \mathrm{C}$. On the 40th day of the observations, the largest number of stolons, on average, was obtained at a temperature of $24-26^{\circ} \mathrm{C}-63.6 \%$, and microtubers - at $14-16^{\circ} \mathrm{C}-69.5 \%$.

\footnotetext{
${ }^{5}$ Куценко В. С., Осипчук А. А., Подгаєцький А. А. [та ін.].Методичні рекомендації щодо проведення досліджень з картоплею. Немішаєве : Ін-т картопл., 2002. 183 с.

${ }^{6}$ Вожегова Р. А., Лавриненко Ю. О., Балашова Г. С. [та ін.]. Оздоровлення картоплі в культурі in vitro: науково-методичні рекомендації. Херсон, Ін-т зрош. землероб., 2013. 20 с.

Лавриненко Ю. А., Балашова Г. С., Котова Е. И. Продуктивность растений картофеля в культуре меристем in vitro. Оралдын гылым жаршысы (Уральский научный вестник). 2015. № 12(143). C. 34-38.
} 
Table 1

The influence of temperature and light intensity on the growth and development of plants of early-ripening potato variety Kobza in vitro

\begin{tabular}{|c|c|c|c|c|c|c|c|c|c|c|c|}
\hline \multirow{4}{*}{ 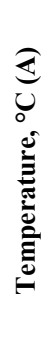 } & \multirow{4}{*}{ 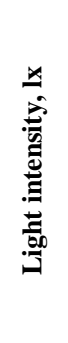 } & \multicolumn{10}{|c|}{ Day of growing } \\
\hline & & \multicolumn{4}{|c|}{ 20th } & \multicolumn{4}{|c|}{ 40th } & 60th & 80th \\
\hline & & \multirow{2}{*}{ 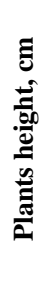 } & \multirow{2}{*}{ 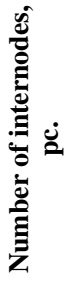 } & \multicolumn{2}{|c|}{$\begin{array}{l}\% \text { of plants } \\
\text { that formed }\end{array}$} & \multirow{2}{*}{ 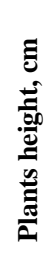 } & \multirow{2}{*}{ 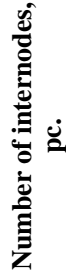 } & \multicolumn{4}{|c|}{$\%$ of plants that formed } \\
\hline & & & & $\frac{\mathscr{a}}{\frac{a}{o}}$ & 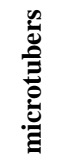 & & & $\frac{\tilde{a}}{\frac{0}{0}}$ & 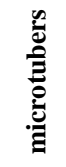 & 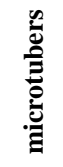 & 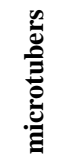 \\
\hline \multirow{4}{*}{$\frac{0}{ \pm}$} & 500 & 1.4 & 1.3 & 82.5 & 11.1 & 2.0 & 1.8 & 11.1 & 87.9 & 96.9 & 100.0 \\
\hline & 1500 & 1.5 & 1.4 & 87.0 & 4.9 & 2.2 & 1.9 & 21.5 & 78.5 & 91.5 & 100.0 \\
\hline & 2000 & 1.8 & 1.7 & 81.5 & 7.7 & 3.7 & 3.2 & 36.4 & 57.3 & 90.0 & 100.0 \\
\hline & 3000 & 1.5 & 1.3 & 82.9 & 5.3 & 3.4 & 2.5 & 45.1 & 54.2 & 87.8 & 99.6 \\
\hline \multirow{4}{*}{ ते } & 500 & 3.6 & 3.1 & 72.3 & 9.4 & 4.3 & 3.9 & 32.6 & 54.7 & 70.8 & 84.8 \\
\hline & 1500 & 3.8 & 3.3 & 79.5 & 5.9 & 4.6 & 4.1 & 44.4 & 48.0 & 69.8 & 91.7 \\
\hline & 2000 & 3.9 & 3.4 & 73.4 & 11.8 & 5.7 & 4.8 & 40.7 & 50.8 & $\begin{array}{l}77.8 \\
\end{array}$ & 96.9 \\
\hline & 3000 & 3.7 & 3.3 & 73.4 & 7.6 & 5.9 & 5.4 & 58.4 & 32.4 & 63.2 & 89.8 \\
\hline \multirow{4}{*}{$\begin{array}{l}\stackrel{+}{\sim} \\
\dot{I}\end{array}$} & 500 & 4.4 & 3.4 & 49.6 & 2.6 & $\begin{array}{l}6.4 \\
\end{array}$ & 5.3 & 60.1 & 12.4 & 26.9 & 53.2 \\
\hline & 1500 & 4.4 & 4.2 & 48.4 & 2.0 & 7.1 & 5.9 & 62.3 & 10.5 & 34.6 & 62.3 \\
\hline & 2000 & 4.2 & 4.0 & 59.2 & 1.2 & 6.6 & 5.7 & 66.9 & 11.7 & 38.6 & 62.7 \\
\hline & 3000 & 4.1 & 3.8 & 56.0 & 2.1 & 6.3 & 5.5 & 64.9 & 12.1 & 43.7 & 69.4 \\
\hline
\end{tabular}

The correlation between the total number of microtubers that were formed by the plants in vitro, the output of microtubers with weight of more than $350 \mathrm{mg}$ and the interaction of the studied factors is strong ( $R=0.878$ and 0.895). A strong inverse pair relationship was found between growing temperature and plant productivity in vitro: the number and mass of microtubers formed, the mass of the average microtuber. The pair correlation coefficients are, respectively, $\mathrm{r}=-0.895+0.141 ;-0.895 \pm 0.141 ;-0.801 \pm 0.189$ (Table 2$)$.

Table 2

\section{Correlation coefficients ( $r)$ of the plant productivity in vitro of early-ripening potato variety Kobza depending on temperature and light intensity}

\begin{tabular}{|c|c|c|}
\hline Index & $\begin{array}{c}\text { Temperature, }^{\circ} \mathbf{C}, \\
\text { factor A }^{-}\end{array}$ & $\begin{array}{c}\text { Light intensity, lx, } \\
\text { factor B }\end{array}$ \\
\hline $\begin{array}{c}\text { The mass of the average } \\
\text { microtuber, mg }\end{array}$ & $-0.801 \pm 0.189$ & $0.512 \pm 0.272$ \\
\hline $\begin{array}{c}\text { The mass of microtubers } \\
\text { per plant, mg }\end{array}$ & $-0.895 \pm 0.141$ & $0.377 \pm 0.293$ \\
\hline $\begin{array}{c}\text { The output of microtubers with } \\
\text { the mass of more than 350 mg, } \%\end{array}$ & $-0.673 \pm 0.234$ & $0.590 \pm 0.255$ \\
\hline $\begin{array}{c}\text { The number of microtubers } \\
\text { per plant, pc. }\end{array}$ & $-0.895 \pm 0.141$ & $0.089 \pm 0.315$ \\
\hline
\end{tabular}


There is a mean inverse correlation $(r=-0.673 \pm 0.234)$ between temperature conditions and the output of microtubers weighing more than $350 \mathrm{mg}$. On the 60th day of the observation, most microtubers were formed by the plants at a temperature of $14-16^{\circ} \mathrm{C}, 91.6 \%$ of their total number, at $20-22^{\circ} \mathrm{C}-70.4 \%$ at $24-26^{\circ} \mathrm{C}$ with only $36.0 \%$, and on the 80 th day according to the specified temperature regimes, the index was $99.9 ; 90.8$ and $61.9 \%$, respectively.

On the day 20 ofgrowing, the light intensity had little effect on the induction of tuber formation and only $4.3-7.7 \%$ of the plants in vitro formed microtubers. The number of plants that formed stolons was also not affected by this factor during the mentioned period. On the 40th day of the observation, the highest quantity of the plants $(51.7 \%)$ that formed microtubers were (on average, by factor) at a light intensity of $500 \mathrm{~lx}$. On the 60th day of the observation, the number of microtuber-forming plants under illumination modes of 500,1500, 2000, and $3000 \mathrm{~lx}$, on average by factor, was $64.9 ; 65.3 ; 68.8$ and $64.9 \%$, respectively.

On the 80th day of the plant growing (Fig. 1), the percentage of microtubers was evened, on average by factor, a;most through all the variants of the experiment in exception of the variants with light intensity of $5001 x$.

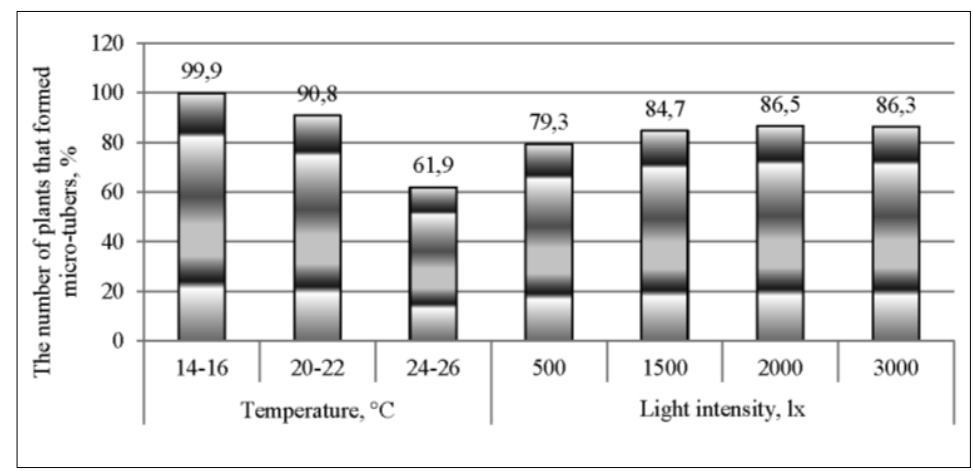

Fig. 1. Influence of temperature and light intensity on the processes of tuberization of the plants of early-ripening variety Kobza in vitro

This indicator was at light $1500-3000 \mathrm{~lx} 84.7-86.5 \%$, and at $500 \mathrm{~lx}-$ $79.3 \%$, i.e., the intensity of illumination almost did not affect the formation of microtubers by the plants in vitro of early-ripening potato variety Kobza. 
Regarding the interaction of factors, it was found that the largest number of plants with microtubers was formed on the 80th day of growing at a temperature of $14-16^{\circ} \mathrm{C}$ and light intensity of 500-3000 lx $-99.6-100 \%$. The multiple correlation index $\mathrm{R}$ was 0.878 .

The interaction of growing temperature and light intensity had a very strong effect on the plant productivity in vitro (Table 3 ).

Table 3

Productivity of early-ripening potato variety Kobza plants in vitro depending on temperature and light intensity

\begin{tabular}{|c|c|c|c|c|c|}
\hline $\begin{array}{c}\text { Temperature, } \\
{ }^{\circ} \mathrm{C} \text { (A) }\end{array}$ & $\begin{array}{c}\text { Light } \\
\text { intensity, } \\
\text { lx (B) }\end{array}$ & $\begin{array}{l}\text { The mass } \\
\text { of } \\
\text { microtuber, } \\
\text { mg }\end{array}$ & $\begin{array}{c}\text { The mass of } \\
\text { microtubers, } \\
\text { mg/plant }\end{array}$ & $\begin{array}{c}\text { The output } \\
\text { of } \\
\text { microtubers } \\
\text { with the } \\
\text { mass of } \\
\text { more than } \\
350 \mathrm{mg}, \%\end{array}$ & $\begin{array}{c}\text { The number } \\
\text { of } \\
\text { microtubers, } \\
\text { pc./plant }\end{array}$ \\
\hline \multirow{4}{*}{$14-16$} & 500 & 163.8 & 224.6 & 6.8 & 1.2 \\
\hline & 1500 & 210.9 & 266.4 & 15.8 & 1.2 \\
\hline & 2000 & 263.8 & 369.1 & 24.3 & 1.1 \\
\hline & 3000 & 262.0 & 363.7 & 20.9 & 1.2 \\
\hline \multirow{4}{*}{$20-22$} & 500 & 95.0 & 82.3 & 0.4 & 0.9 \\
\hline & 1500 & 138.8 & 143.0 & 6.0 & 1.1 \\
\hline & 2000 & 140.7 & 154.1 & 6.2 & 1.1 \\
\hline & 3000 & 174.0 & 186.1 & 11.4 & 0.9 \\
\hline \multirow{4}{*}{$24-26$} & 500 & 60.5 & 42.8 & 0.0 & 0.6 \\
\hline & 1500 & 128.9 & 81.4 & 6.8 & 0.6 \\
\hline & 2000 & 132.1 & 82.4 & 7.2 & 0.6 \\
\hline & 3000 & 132.2 & 119.1 & 9.4 & 0.8 \\
\hline \multicolumn{2}{|c|}{$\begin{array}{c}\text { The index of multiple } \\
\text { correlation }(\mathrm{R})\end{array}$} & 0.951 & 0.971 & 0.895 & 0.878 \\
\hline \multicolumn{2}{|c|}{$\mathrm{LSD}_{05}, \mathrm{mg} \mathrm{A}$} & 14.6 & 8.6 & & \\
\hline \multicolumn{2}{|l|}{ B } & 12.1 & 13.9 & & \\
\hline
\end{tabular}

The average microtuber mass and the microtuber mass per plant were maximal at a temperature of $14-16^{\circ} \mathrm{C}$ and illumination of 2000 and $3000 \mathrm{~lx}$ and were, respectively, 263.8; 369.1 and $262.0 ; 363.7 \mathrm{mg}$. Also, in these variants, the highest yield of microtubers weighing $350 \mathrm{mg}$ and more was observed -24.3 and $20.9 \%$ (Fig. 2). The correlation between the mean microtuber mass, the microtuber mass per plant and the factors studied was very close: $R=0.951$ and 0.971 , respectively. 


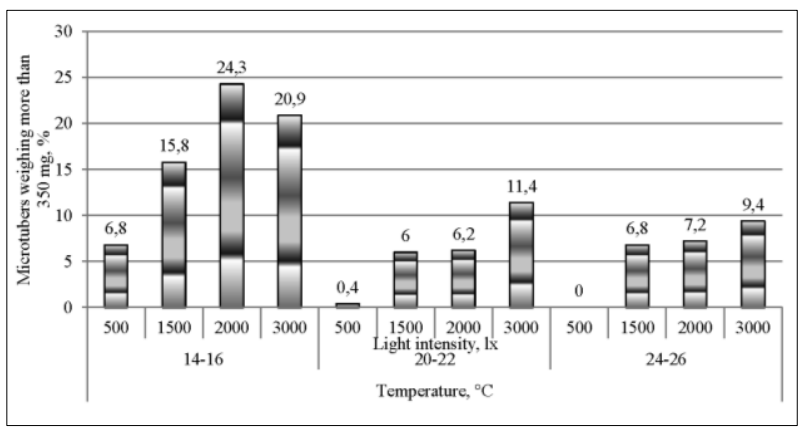

Fig. 2. In vitro productivity of early-ripening variety Kobza depending on temperature and light intensity

With the increase of growing temperature, the compensatory effect of the intensity of illumination on the performance of the plants in vitro is engaged: the total mass of microtubers per plant $(\mathrm{r}=0,377 \pm 0,293)$, the average mass of microtubers $(\mathrm{r}=0,512 \pm 0,272)$, and the output of microtubers weighing more than $350 \mathrm{mg}(\mathrm{r}=0,590 \pm 0,255)$. At a temperature of $20-22^{\circ} \mathrm{C}$ the productivity of plants was lower than at a temperature of $14-16^{\circ} \mathrm{C}$. The lack of productivity is compensated at the highest level of illumination - $3000 \mathrm{~lx}$ : the mass of the average microtuber is increased by $83.2 \%$, and the mass of microtubers per plant is increased 1.3 times in comparison to the illumination of $500 \mathrm{~lx}$. At a temperature of $24-26^{\circ} \mathrm{C}$, the highest productivity was obtained under the illumination of $3000 \mathrm{~lx}$.

By the results of ANOVA, on average for 3 years, the greatest effect on the mass of microtubers per plant had the temperature regime (factor A), much less - the illumination (factor B) (Fig. 3).

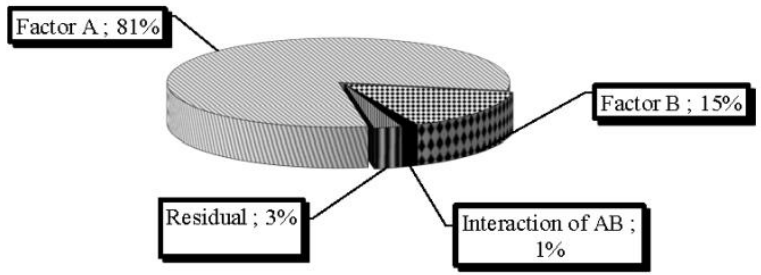

Fig. 3. The share of the effect of temperature and light intensity on the formation of microtuber mass per plant in vitro of early-ripening potato variety Kobza 
The regression analysis of the obtained data allowed to obtain linear mathematical models of the dependence of productivity of the potato plants of early-ripening variety Kobza in vitro depending on the interaction of growing temperature and light intensity (Table 4).

Table 4

Regression equation of the dependence of productivity indexes of the potato plants of early-ripening variety Kobza in vitro on temperature $\left(X_{1}\right)$ and light intensity $\left(X_{2}\right)$

\begin{tabular}{|c|c|}
\hline Index & Equation \\
\hline The mass of average microtuber, $\mathrm{mg}$ & $Y=321.4-11.45 X_{1}+0.0334 X_{2}$ \\
\hline The mass of microtubers per plant, mg & $Y=541.16-22.85 X_{1}+0.0439 X_{2}$ \\
\hline $\begin{array}{c}\text { The output of microtubers with the mass } \\
\text { of more than } 350 \mathrm{mg}, \%\end{array}$ & $Y=24.0-1.17 X_{1}+0.00466 X_{2}$ \\
\hline The number of microtubers per plant, pc. & $Y=1.88-0.0507 X_{1}+2.3 E-5 X_{2}$ \\
\hline
\end{tabular}

It is determined that the decisive factor in the process of plant morphogenesis in vitro of the plants of early-ripening potato variety Kobza and the formation of their productivity are growing temperature conditions, light intensity affects much less. The maximum performance of the plants in vitro was obtained through the usage of a temperature regime of $14-16^{\circ} \mathrm{C}$ and illumination of 2000-3000 lx.

At the growing temperature of $14-16^{\circ} \mathrm{C}$, the cost of a unit of product was 5.21 UAH, and its increase to $20-22$ and $24-26^{\circ} \mathrm{C}$ caused the increase of the cost of microtuber 1.2 and 1.9 times and the decrease of profitability - by 54 and $147 \%$, respectively (Table 5).

Light intensity had no significant impact on the economic indexes. The lowest cost of a microtuber and the maximum profitability of production are formed at a growing temperature of $14-16^{\circ} \mathrm{C}$ and light intensity of $500 \mathrm{~lx}$ : UAH 4.93 and $224 \%$, respectively.

In the conditions of southern arid climate, it is important to select microtubers with the possibly largest mass, which in the future will allow obtaining the maximum number of healthy potato minitubers and will help to increase the yields of pre-basic and basic seeds. Taking this into account during determination of the optimal elements of the technology of growing microtubers of early-ripening potato variety Kobza in vitro, it was established that the optimal productivity and economic indexes of growing laboratory plants are at a growing temperature of $14-16^{\circ} \mathrm{C}$ and light intensity of 3000 lx. Herewith, the number of microtubers per plant was $1.2 \mathrm{pc}$., the average microtuber mass was $262.0 \mathrm{mg}$, the microtubers mass per plant was $363.7 \mathrm{mg}$, and the number of microtubers with the mass of $350.0 \mathrm{mg}$ and 
more was $20.9 \%$; the production cost of a microtuber was $5.31 \mathrm{UAH}$ at the profitability of $201 \%$.

Table 5

Economic efficiency of growing microtubers of early-ripening potato variety Kobza in vitro depending on temperature and light intensity

\begin{tabular}{|c|c|c|c|c|c|c|}
\hline $\begin{array}{c}\text { Temperature, } \\
{ }^{\circ} \mathrm{C} \text { (A) }\end{array}$ & 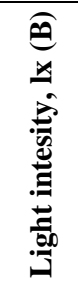 & 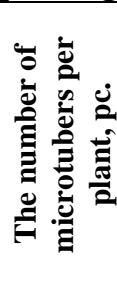 & 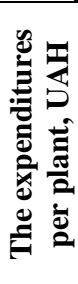 & 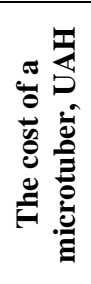 & 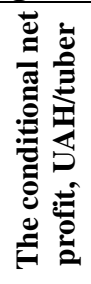 & 这 \\
\hline \multirow{4}{*}{$14-16$} & 500 & 1.2 & 5.92 & 4.93 & 11.07 & 224 \\
\hline & 1500 & 1.2 & 6.01 & 5.01 & 10.99 & 219 \\
\hline & 2000 & 1.1 & 6.15 & 5.59 & 10.41 & 186 \\
\hline & 3000 & 1.2 & 6.37 & 5.31 & 10.69 & 201 \\
\hline \multirow{4}{*}{$20-22$} & 500 & $\begin{array}{l}0.9 \\
\end{array}$ & 5.97 & 6.63 & 9.37 & 141 \\
\hline & 1500 & 1.1 & 6.28 & 5.71 & 10.29 & 180 \\
\hline & 2000 & 1.1 & 6.41 & 5.83 & 10.17 & 174 \\
\hline & 3000 & 0.9 & 6.55 & 7.28 & 8.72 & 121 \\
\hline \multirow{4}{*}{$24-26$} & 500 & 0.6 & 6.11 & 10.18 & 5.82 & 57 \\
\hline & 1500 & 0.6 & 6.43 & 10.72 & 5.28 & 49 \\
\hline & 2000 & 0.6 & 6.62 & 11.03 & 4.97 & 45 \\
\hline & 3000 & 0.8 & 6.70 & 8.38 & 7.62 & 91 \\
\hline
\end{tabular}

2. The intensity of potato tuberization in vitro depending on the duration of the photoperiod, temperature, level of nitrogen nutrition and the period of substitution of the nutrient medium

A four-factor experiment was conducted by microclonal laboratory of the Institute of Irrigated Agriculture of NAAS to determine the most optimal regime of the middle-ripening potato variety Nevska tuberization in vitro. The following factors were put to the study: A - duration of photoperiod (10 and 16 hours); $\mathrm{B}$ - temperature regimes $\left(18-20\right.$ and $\left.23-25^{\circ} \mathrm{C}\right)$; $\mathrm{C}$ - nitrogen content in the nutrient medium (full and half norm, no nitrogen); D - medium substitution times (on the 10th and 20th day).

Cuttings of the plants of the middle-ripening potato variety Nevska were grown on a complete liquid nutrient medium of Murashige, Skoog (MS) at 10 and 16 hours of illumination per day at temperatures of $18-20$ and $23-25^{\circ} \mathrm{C}$. On the 10th day, the cuttings of one group were transferred from a complete nutrient solution with a nitrogen content of $868 \mathrm{mg} / \mathrm{L}$ to the solution with $1 / 2$ nitrogen $(434 \mathrm{mg} / \mathrm{L})$ and with no nitrogen. In the second group of the plants 
the nutrient medium was changed after 20 days. The photoperiod and temperatures were maintained as before.

Observations on the plant growth and tuberization intensity showed that in vitro plants were $10.8 \%$ higher under the repacement of the nutrient medium on the 10th day of growing at the background of 10-hour illumination than those exposed to 16-hour illumination (Table 6). There was no difference in the number of internodes. The number of plants with microtubers on the twentieth day of the observation at thethe background of the ten-hour photoperiod was $1.7 \%$, and at the sixteenth hour $-0.5 \%$. But on the 40th day, this index was, respectively, 17.9 and $11.3 \%$, and on the 60th -39.4 and $39.1 \%$. The total number of microtubers during the entire vegetation period was $83.4 \%$ at the tenhour photoperiod, and $73.9 \%$ at the sixteenth hour.

Table 6

Influence of growing conditions on growth, in vitro development of the plants of the middle-early potato variety Nevska at changing the medium on the 10th day of cultivation

\begin{tabular}{|c|c|c|c|c|c|c|c|c|c|c|c|c|}
\hline \multirow[b]{3}{*}{ 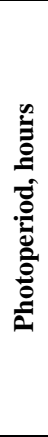 } & \multirow[b]{3}{*}{ 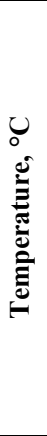 } & \multirow[b]{3}{*}{$\begin{array}{l}\text { Nitrogen } \\
\text { content }\end{array}$} & \multicolumn{9}{|c|}{ The indexes on the day of cutting } & \multirow{3}{*}{ 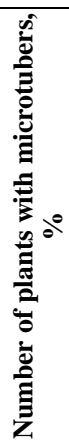 } \\
\hline & & & \multicolumn{3}{|c|}{20 th } & \multicolumn{3}{|c|}{ 40th } & \multicolumn{3}{|c|}{ 60th } & \\
\hline & & & 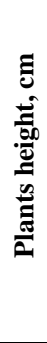 & 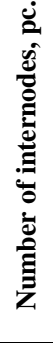 & 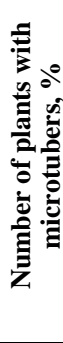 & 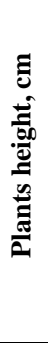 & 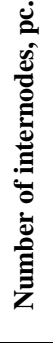 & 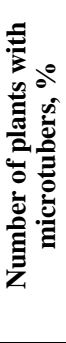 & 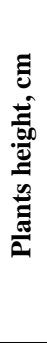 & 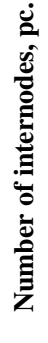 & 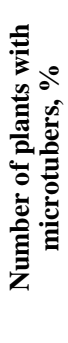 & \\
\hline \multirow{6}{*}{ 은 } & \multirow{3}{*}{$\begin{array}{l}\text { तิ } \\
\infty \\
\infty\end{array}$} & Full norm & 3.6 & 3.2 & 5.5 & 5.0 & 4.5 & 43.0 & 5.5 & 5.8 & 71.9 & 95.0 \\
\hline & & $1 / 2$ norm & 3.7 & 2.9 & 1.3 & 4.4 & 3.8 & 21.2 & 4.7 & 4.1 & 42.5 & 94.5 \\
\hline & & $\begin{array}{c}\text { No } \\
\text { nitrogen }\end{array}$ & 3.5 & 3.0 & 1.7 & 4.2 & 3.6 & 25.4 & 4.7 & 4.3 & 45.4 & 98.1 \\
\hline & \multirow{3}{*}{ 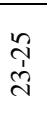 } & Full norm & 4.7 & 3.7 & 0.0 & 6.0 & 4.8 & 5.8 & 6.6 & 5.8 & 18.4 & 52.1 \\
\hline & & $1 / 2$ norm & 4.2 & 3.1 & 0.7 & 5.9 & 4.1 & 7.5 & 6.8 & 5.4 & 30.5 & 72.5 \\
\hline & & $\begin{array}{c}\text { No } \\
\text { nitrogen }\end{array}$ & 4.6 & 3.5 & 0.7 & 5.4 & 4.2 & 4.2 & 6.7 & 5.7 & 27.5 & 88.1 \\
\hline \multirow{6}{*}{$\underline{0}$} & \multirow{3}{*}{$\begin{array}{l}\text { तิ } \\
\infty \\
\infty\end{array}$} & Full norm & 3.5 & 3.2 & 1.2 & 5.4 & 4.9 & 24.3 & 6.1 & 5.8 & 47.5 & 92.6 \\
\hline & & $1 / 2$ norm & 3.1 & 3.0 & 0.5 & 3.7 & 3.6 & 13.6 & 4.4 & 4.1 & 40.6 & 87.5 \\
\hline & & $\begin{array}{c}\text { No } \\
\text { nitrogen }\end{array}$ & 2.8 & 2.6 & 0.8 & 3.3 & 3.3 & 14.2 & 3.6 & 3.7 & 38.7 & 97.0 \\
\hline & \multirow{3}{*}{ 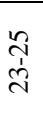 } & Full norm & 4.6 & 3.8 & 0.0 & 5.9 & 5.4 & 5.8 & 6.5 & 6.2 & 37.9 & 46.4 \\
\hline & & $1 / 2$ norm & 4.2 & 3.7 & 0.3 & 5.5 & 4.7 & 7.8 & 6.2 & 5.6 & 23.5 & 54.2 \\
\hline & & $\begin{array}{c}\text { No } \\
\text { nitrogen }\end{array}$ & 4.2 & 3.5 & 0.0 & 5.1 & 4.2 & 2.0 & 5.9 & 5.2 & 9.4 & 65.9 \\
\hline
\end{tabular}


It was found that the increase in the temperature of growing to $23-25^{\circ} \mathrm{C}$ provided the increase in the number of internodes of the plants in vitro during the first 20 days of growth and development by $19.0 \%$, on the 60th and 80th day - by 15.6 and $29.9 \%$, respectively. Plants height under the maintaining of the temperature regime at the level of $23-25^{\circ} \mathrm{C}$ was $30.0-33.4 \%$ higher during the whole cultivation period than at $18-20^{\circ} \mathrm{C}$. On the 40th day of cultivation at the temperature of $18-20^{\circ} \mathrm{C}$ the number of plants with microtubers was $23.6 \%$ that was 4.3 times higher than at the temperature of $23-25^{\circ} \mathrm{C}$. In general, for the entire cultivation period, at $18-20^{\circ} \mathrm{C}$ the microtubers were formed on $94.1 \%$ of the plants in vitro and at $23-25^{\circ} \mathrm{C}-$ on $63.2 \%$.

It was determined that replacing of the nutrient medium on the 20th day of cultivation resulted in more intensive process of tuberization than at replacing it on the 10th day (Table 7). Overall, $82.8 \%$ and $78.7 \%$ of the plants formed microtubers, respectively.

Table 7

Influence of growing conditions on growth, in vitro development of the plants of the middle-early potato variety Nevska at changing the medium on the 20th day of cultivation

\begin{tabular}{|c|c|c|c|c|c|c|c|c|c|c|c|c|}
\hline \multirow[b]{3}{*}{ 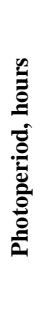 } & \multirow[b]{3}{*}{ 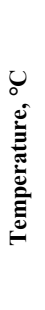 } & \multirow[b]{3}{*}{$\begin{array}{c}\text { Nitrogen } \\
\text { content }\end{array}$} & \multicolumn{9}{|c|}{ The indexes on the day of cutting } & \multirow[b]{3}{*}{ 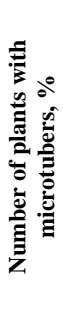 } \\
\hline & & & \multicolumn{3}{|c|}{ 20th } & \multicolumn{3}{|c|}{ 40th } & \multicolumn{3}{|c|}{ 60th } & \\
\hline & & & 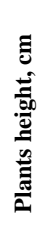 & 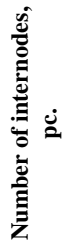 & 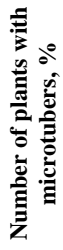 & 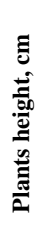 & 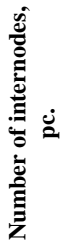 & 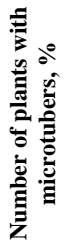 & 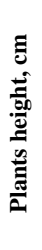 & 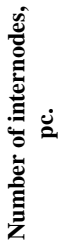 & 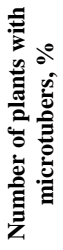 & \\
\hline \multirow{6}{*}{ 은 } & \multirow{3}{*}{$\begin{array}{l}\text { तิ } \\
\infty \\
\infty\end{array}$} & Full norm & 4.1 & 3.4 & 4.4 & 5.5 & 5.0 & 39.4 & 6.2 & 5.6 & 73.0 & 94.3 \\
\hline & & $1 / 2$ norm & 3.5 & 3.0 & 3.4 & 4.3 & 4.0 & 37.1 & 5.1 & 4.9 & 71.5 & 98.7 \\
\hline & & $\begin{array}{c}\text { No } \\
\text { nitrogen }\end{array}$ & 3.1 & 2.8 & 0.8 & 4.0 & 3.5 & 27.8 & 4.4 & 4.5 & 75.4 & 98.3 \\
\hline & \multirow{3}{*}{$\begin{array}{l}\text { â } \\
\text { तें } \\
\text { ते }\end{array}$} & Full norm & 4.7 & 3.9 & 0.0 & 6.2 & 5.2 & 5.6 & 6.9 & 6.4 & 12.1 & 52.1 \\
\hline & & $1 / 2$ norm & 4.9 & 3.8 & 0.0 & 6.9 & 5.2 & 4.7 & 7.5 & 6.0 & 37.7 & 79.6 \\
\hline & & $\begin{array}{c}\text { No } \\
\text { nitrogen }\end{array}$ & 5.2 & 4.2 & 0.0 & 6.7 & 5.6 & 2.5 & 7.6 & 6.8 & 25.1 & 87.6 \\
\hline \multirow{6}{*}{$\stackrel{ }{2}$} & \multirow{3}{*}{$\begin{array}{l}\stackrel{\overbrace{}}{1} \\
\infty \\
\infty\end{array}$} & Full norm & 3.9 & 3.6 & 1.1 & 6.0 & 5.4 & 16.1 & 6.2 & 6.0 & 52.1 & 92.7 \\
\hline & & $1 / 2$ norm & 4.2 & 3.8 & 0.0 & 5.9 & 5.4 & 10.9 & 6.1 & 5.6 & 56.1 & 100.0 \\
\hline & & $\begin{array}{c}\text { No } \\
\text { nitrogen }\end{array}$ & 4.0 & 3.6 & 0.0 & 5.5 & 5.0 & 10.6 & 6.1 & 5.7 & 53.7 & 99.2 \\
\hline & \multirow{3}{*}{ 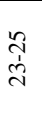 } & Full norm & 4.4 & 3.7 & 0.0 & 6.1 & 5.6 & 4.4 & 6.7 & 6.3 & 26.2 & 46.5 \\
\hline & & $1 / 2$ norm & 4.8 & 3.7 & 0.0 & 6.1 & 5.3 & 4.8 & 6.6 & 6.0 & 38.7 & 69.4 \\
\hline & & $\begin{array}{c}\text { No } \\
\text { nitrogen }\end{array}$ & 4.8 & 4.1 & 0.0 & 5.9 & 5.3 & 6.0 & 6.4 & 5.7 & 39.9 & 75.3 \\
\hline
\end{tabular}


At transferring of the plants in vitro on the day 10 from full nutrient medium to medium containing $1 / 2$ amount of nitrogen and medium without nitrogen, on the 40th day of cultivation the plants height decreased by 12.6 and $19.3 \%$ and the number of internodes - by 17,3 and $21.9 \%$, respectively. On the 60th day of cultivation, the plants height and the number of internodes in the medium with a half norm of nitrogen were lower by 10.5 and $18.6 \%$, respectively, than at the background with the full norm, and in the medium without nitrogen - by 15.4 and $19.9 \%$, respectively. However, without the use of nitrogen and at the application of the half of its norm for the whole period of cultivation, the total number of plants with microtubers increased by 15.8 and 5.7 percent, respectively. When transferring the plants in vitro on the 20th day of cultivation, these rates were 18.7 and 15.5 percent, respectively.

There was a strong correlation dependence between the number of generated microtubers per plant and the interaction of the studied factors $(\mathrm{R}=0.863)$ (Table 8).

Table 8

Coefficients ( $r$ ) of correlation dependence of the plants productivity in vitro of the middle-early potato variety Nevska in regard

to the duration of the photoperiod, temperature, level of nitrogen nutrition and substitution period of the nutrient medium

\begin{tabular}{|c|c|c|c|}
\hline Studied factors & $\begin{array}{c}\text { Mass of } \\
\text { average } \\
\text { microtuber, } \\
\text { mg }\end{array}$ & $\begin{array}{c}\text { Mass of } \\
\text { microtubers per } \\
\text { plant, mg }\end{array}$ & $\begin{array}{c}\text { Number of } \\
\text { microtubers } \\
\text { per plant, pc. }\end{array}$ \\
\hline Photoperiod, hours, factor A & $0.365 \pm 0.198$ & $0.184 \pm 0.210$ & $-0.097 \pm 0.212$ \\
\hline Temperature, ${ }^{\circ} \mathrm{C}$, factor B & $-0.818 \pm 0.123$ & $-0.852 \pm 0.112$ & $-0.830 \pm 0.119$ \\
\hline $\begin{array}{c}\text { Content of nitrogen in the nutrient } \\
\text { medium, mg/L, factor C }\end{array}$ & $0.034 \pm 0.213$ & $0.038 \pm 0.213$ & $0.055 \pm 0.213$ \\
\hline Substitution period, days, factor D & $0.283 \pm 0.204$ & $0.288 \pm 0.204$ & $0.212 \pm 0.208$ \\
\hline
\end{tabular}

The temperature conditions of cultivation have a greater influence (pair correlation coefficient $\mathrm{r}=-0.830 \pm 0.119$ ) than the photoperiod $(\mathrm{r}=-0.097 \pm 0.212)$, the terms of substitution of the nutrient medium $(r=0.212 \pm 0.208)$ and the nitrogen content in it $(r=0.055 \pm 0.213)$.

The analysis of the data shows that at sixteen-hour illumination in comparison with the ten-hour one, on average, the mass of the micro-tuber increased by $17.8 \%$, and the mass of tubers per plant - by $19.8 \%$ (Table 9 ). 
Table 9

Influence of the level of nitrogen nutrition, temperatures, photoperiod duration and the time of substitution of the nutrient medium on the productivity of potatoes of the middle-early variety Nevska in vitro

\begin{tabular}{|c|c|c|c|c|c|c|}
\hline \multirow[b]{2}{*}{ 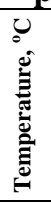 } & \multirow[b]{2}{*}{$\begin{array}{c}\text { Photoperiod, } \\
\text { hours }\end{array}$} & \multirow[b]{2}{*}{$\begin{array}{l}\text { Substitution } \\
\text { of the } \\
\text { medium, } \\
\text { day }\end{array}$} & \multirow[b]{2}{*}{$\begin{array}{c}\text { Nitrogen } \\
\text { content }\end{array}$} & \multirow[b]{2}{*}{$\begin{array}{l}\text { Mass of } \\
\text { microtuber, } \\
\text { mg }\end{array}$} & \multirow[b]{2}{*}{$\begin{array}{c}\text { Mass of } \\
\text { microtubers, } \\
\text { mg/plant }\end{array}$} & \multirow[b]{2}{*}{$\begin{array}{c}\text { Number of } \\
\text { microtubers, } \\
\text { pc./plant }\end{array}$} \\
\hline & & & & & & \\
\hline \multirow{12}{*}{$\begin{array}{l}\stackrel{1}{1} \\
\infty \\
\infty\end{array}$} & \multirow{6}{*}{10} & \multirow{3}{*}{10} & Full & 172.7 & 163.9 & 0.9 \\
\hline & & & $1 / 2$ norm & 139.0 & 133.7 & 1.0 \\
\hline & & & No & 160.3 & 153.8 & 1.0 \\
\hline & & \multirow{3}{*}{20} & Full & 172.7 & 163.9 & 0.9 \\
\hline & & & $1 / 2$ norm & 204.8 & 211.8 & 1.0 \\
\hline & & & No & 201.3 & 213.7 & 1.1 \\
\hline & \multirow{6}{*}{16} & \multirow{3}{*}{10} & Full & 226.7 & 227.0 & 1.0 \\
\hline & & & $1 / 2$ norm & 183.4 & 152.9 & 0.8 \\
\hline & & & No & 179.9 & 174.5 & 1.0 \\
\hline & & \multirow{3}{*}{20} & Full & 226.7 & 227.0 & 1.0 \\
\hline & & & $1 / 2$ norm & 247.6 & 283.2 & 1.2 \\
\hline & & & $\mathrm{No}$ & 259.0 & 286.4 & 1.1 \\
\hline \multirow{6}{*}{$\begin{array}{l}\text { â } \\
\text { ஸे }\end{array}$} & \multirow{6}{*}{10} & \multirow{3}{*}{10} & Full & 81.5 & 48.9 & 0.5 \\
\hline & & & $1 / 2$ norm & 89.6 & 60.0 & 0.7 \\
\hline & & & No & 101.8 & 88.8 & 0.8 \\
\hline & & \multirow{3}{*}{20} & Full & 81.5 & 48.9 & 0.5 \\
\hline & & & $1 / 2$ norm & 108.4 & 86.2 & 0.8 \\
\hline & & & No & 128.8 & 115.0 & 0.9 \\
\hline & \multirow{6}{*}{16} & \multirow{3}{*}{10} & Full & 111.1 & 52.8 & 0.5 \\
\hline & & & $1 / 2$ norm & 139.5 & 71.4 & 0.5 \\
\hline & & & No & 107.5 & 69.4 & 0.6 \\
\hline & & \multirow{3}{*}{20} & Full & 111.1 & 52.8 & 0.5 \\
\hline & & & $1 / 2$ norm & 153.2 & 99.9 & 0.7 \\
\hline & & & No & 148.6 & 111.3 & 0.7 \\
\hline \multicolumn{4}{|c|}{ Multiple correlation index (R) } & 0.94 & 0.918 & 0.863 \\
\hline \multirow{4}{*}{\multicolumn{3}{|c|}{$\mathrm{LSD}_{05}, \mathrm{mg}$}} & A & 11.3 & 9.7 & \\
\hline & & & $\mathrm{B}$ & 10.9 & 8.8 & \\
\hline & & & $\mathrm{C}$ & 8.2 & 9.0 & \\
\hline & & & $\mathrm{D}$ & 7.7 & 6.0 & \\
\hline
\end{tabular}

A very strong correlation was found between the mass of the average microtuber $(R=0.94)$, the mass of microtubers per plant $(R=0.918)$ and the studied factors. At $18-20^{\circ} \mathrm{C}$ temperature, the average microtuber mass was $68.8 \%$ higher than in the $23-25^{\circ} \mathrm{C}$ regime, and the microtubers mass per plant was 2.5 times higher. This is confirmed by the strong inverse pair relationship between the temperature and plant productivity, i.e., with the increase of cultivation temperature, the mass of the average microtuber $(\mathrm{r}=-0.818 \pm 0.123)$, the mass of microtubers per plant $(\mathrm{r}=0.852 \pm 0.112)$ and the number of microtubers formed decrease $(\mathrm{r}=-0.830 \pm 0.119)$. 
At transferring of the cultivated plants from the nutrient medium with a full nitrogen rate to the medium with a half of the norm the mass of the average microtuber increased by $6.9 \%$, the mass of microtubers per plantby $11.6 \%$, and in the medium without nitrogen, these indexes were higher by $8.7 \%$ and $23.1 \%$, respectively.

The mass of an average microtuber and the microtubers mass per plant were higher at the replacing of the nutrient medium on the day 20 than on the day 10 by 31.9 and $49.7 \%$, respectively. So, 20 days of cultivation completely satisfied the requirements in nitrogen, and the subsequent vegetation, the presence of this element did not affect the process of tuberization.

Regression analysis of the gathered data allowed obtaining linear mathematical models of the potato plants productivity of the middle-early ripening variety Nevska in vitro depending on the level of nitrogen nutrition, growing temperature, duration of photoperiod and term of substitution of the nutrient medium (Table 10).

Calculations of the economic efficiency of growing microtubers of middle-early variety of potato Nevska in vitro, depending on the studied factors, showed that the production cost per microtuber, on average, at the cultivation temperatures of $18-20^{\circ} \mathrm{C}$ was 1.8 times lower than at $23-25^{\circ} \mathrm{C}$.

Table 10

Equations of regression depending on the productivity indexes of the plants in vitro of middle-early potato variety Nevska at different temperature of growing $\left(X_{1}\right)$, photoperiod $\left(X_{2}\right)$, term of the nutrient medium substitution $\left(X_{3}\right)$ and level of nitrogen supply $\left(X_{4}\right)$

\begin{tabular}{|c|c|}
\hline Index & Equation \\
\hline Mass of average microtuber, $\mathrm{mg}$ & $Y=374.62-16.86 X 1+6.28 X_{2}+2.92 X_{3}+0.0198 X_{4}$ \\
\hline Mass of microtubers per plant, $\mathrm{mg}$ & $Y=524.58-24.77 X_{1}+4.44 X_{2}+4.19 X_{3}+3.3 E-5 X_{4}$ \\
\hline Number of microtubers & $Y=2.23-0.0717 X_{1}-0.00694 X_{2}+0.00917 X_{3}+$ \\
per plant, pc. & $+0.000132 X_{4}$ \\
\hline
\end{tabular}

The production cost of microtuber at the use of a sixteen-hour photoperiod increased by $13.2 \%$, compared to ten hours of illumination, on average by the factor (Table 11). substitution of the nutrient medium on the 20 th day of cultivation reduced the production cost by $8.7 \%$; owing to the transfer of the cultivated plants from a nutrient medium with a full nitrogen rate to a medium with a half of the norm, the production cost of a microtuber is reduced by $17.6 \%$, for a medium without nitrogen - by $25.7 \%$.

The maximum productivity and the outpay of investments at the determination of the optimum elements of technology for growing microtubers 
of the middle-early potato variety Nevska in vitro, taking into account such a significant factor as the size of the obtained microtubers, was got under the combination of the factors: 16 hours illumination, $18-20^{\circ} \mathrm{C}$ cultivation temperature, the substitution of the nutrient medium on the 20th day of cultivation on the medium with a half of the norm of nitrogen. Herewith, the number of microtubers per plant is $1.2 \mathrm{pc}$, the mass of an average microtuber is $247.6 \mathrm{mg}$, the microtuber mass per plant is $283.2 \mathrm{mg}$; the production cost of a microtuber is $5.24 \mathrm{UAH}$ at the profitability of production at $205 \%$.

Table 11

Economic efficiency of potato microtubers production of the middle-early variety Nevska in vitro depending on the cultivation temperature, photoperiod, nutrient medium substitution term and nitrogen supply level

\begin{tabular}{|c|c|c|c|c|c|c|c|c|}
\hline 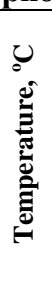 & 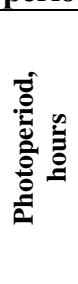 & 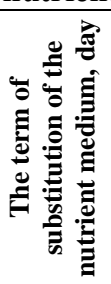 & $\begin{array}{c}\text { Nitrogen } \\
\text { content }\end{array}$ & 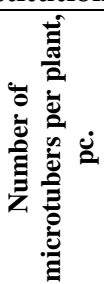 & 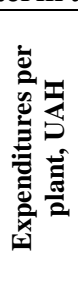 & 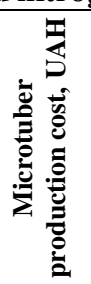 & 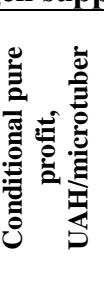 & 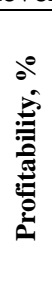 \\
\hline \multirow{12}{*}{ 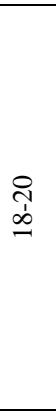 } & \multirow{6}{*}{10} & \multirow{3}{*}{10} & Full norm & 0.9 & 6.00 & 6.67 & 9.33 & 140 \\
\hline & & & $1 / 2$ norm & 1.0 & 5.95 & 5.95 & 10.05 & 169 \\
\hline & & & No nitrogen & 1.0 & 5.90 & 5.90 & 10.10 & 171 \\
\hline & & \multirow{3}{*}{20} & Full norm & 0.9 & 6.12 & 6.80 & 9.20 & 135 \\
\hline & & & $1 / 2$ norm & 1.0 & 6.07 & 6.07 & 9.93 & 164 \\
\hline & & & No nitrogen & 1.1 & 6.02 & 5.47 & 10.53 & 192 \\
\hline & \multirow{6}{*}{16} & \multirow{3}{*}{10} & Full norm & 1.0 & 6.22 & 6.22 & 9.78 & 157 \\
\hline & & & $1 / 2$ norm & 0.8 & 6.17 & 7.71 & 8.29 & 107 \\
\hline & & & No nitrogen & 1.0 & 6.12 & 6.12 & 9.88 & 161 \\
\hline & & \multirow{3}{*}{20} & Full norm & 1.0 & 6.34 & 6.34 & 9.66 & 152 \\
\hline & & & $1 / 2$ norm & 1.2 & 6.29 & 5.24 & 10.76 & 205 \\
\hline & & & No nitrogen & 1.1 & 6.24 & 5.67 & 10.33 & 182 \\
\hline \multirow{12}{*}{$\begin{array}{l}\text { ते } \\
\text { ते }\end{array}$} & \multirow{6}{*}{10} & \multirow{3}{*}{10} & Full norm & 0.5 & 6.60 & 13.20 & 2.80 & 21 \\
\hline & & & $1 / 2$ norm & 0.7 & 6.55 & 9.35 & 6.65 & 71 \\
\hline & & & No nitrogen & 0.8 & 6.49 & 8.11 & 7.89 & 97 \\
\hline & & \multirow{3}{*}{20} & Full norm & 0.5 & 6.73 & 13.46 & 2.54 & 19 \\
\hline & & & $1 / 2$ norm & 0.8 & 6.68 & 8.35 & 7.65 & 92 \\
\hline & & & No nitrogen & 0.9 & 6.62 & 7.36 & 8.64 & 117 \\
\hline & \multirow{6}{*}{16} & \multirow{3}{*}{10} & Full norm & 0.5 & 6.84 & 13.68 & 2.32 & 17 \\
\hline & & & $1 / 2$ norm & 0.5 & 6.79 & 13.57 & 2.43 & 18 \\
\hline & & & No nitrogen & 0.6 & 6.73 & 11.22 & 4.78 & 43 \\
\hline & & \multirow{3}{*}{20} & Full norm & 0.5 & 6.97 & 13.95 & 2.05 & 15 \\
\hline & & & $1 / 2$ norm & 0.7 & 6.92 & 9.88 & 6.12 & 62 \\
\hline & & & No nitrogen & 0.7 & 6.86 & 9.81 & 6.19 & 63 \\
\hline
\end{tabular}




\section{CONCLUSIONS}

1. A strong and average inverse pair relationship between the temperature and the plant productivity during in vitro cultivation of earlyripening potato variety Kobza $(r=-0.801 ;-0.895 ;-0.673 ;-0.895)$ has been established, i.e., by increasing the cultivation temperature, the mass of the average microtuber decreases, the mass of the microtubers per plant decreases, the output of microtubers weighing more than $350 \mathrm{mg}$ and the number of microtubers formed decreases, respectively.

2. It was found that the decisive factor in the process of the plant morphogenesis in vitro of the early-ripening potato variety Kobza and the formation of its productivity were the cultivation temperature conditions, and the light intensity affected much less.

3. In the conditions of southern arid climate, it is of particular importance to obtain in vitro microtubers with bigger mass, which have an increased capacity to produce the maximum number of healthy potato minitubers that further will be favorable for getting high yields of pre-basic and basic seed material. Therefore, taking into account this factor, at the determination of the optimum elements of growing technology of the early-ripening potato variety Kobza microtubers in the meristem in vitro culture, it was determined that optimal productivity indexes and economic efficiency of the in vitro plants cultivation are provided at the temperature of $14-16^{\circ} \mathrm{C}$ and light intensity $3000 \mathrm{~lx}$. The number of microtubers per plant $-1.2 \mathrm{pc}$., the mass of an average microtuber $262.0 \mathrm{mg}$, the mass of the microtubers per plant $-363.7 \mathrm{mg}$, the number of microtubers weighing more than $350.0 \mathrm{mg}-20.9 \%$; production cost of the microtuber - 5.31 UAH at the profitability of $201 \%$.

4. The maximum productivity and outpay of the investments at the determination of the optimum elements of growing technology of microtubers of the middle-ripening potato variety Nevska in vitro culture was obtained at the combination of the factors: illumination of 16 hours, cultivation temperature $18-20^{\circ} \mathrm{C}$, substitution of the full nutrient medium Murashige, Skoog (MS) on the medium with a half of the norm of nitrogen on the 20th day of the cultivation. The number of microtubers per plant $1.2 \mathrm{pc}$., the mass of an average microtuber $-247.6 \mathrm{mg}$, the mass of the microtubers per plant $-283.2 \mathrm{mg}$; the production cost of the microtuber $5.24 \mathrm{UAH}$ at the profitability of production of $205 \%$.

\section{SUMMARY}

Taking under consideration a considerable cost of the seed material obtained in vitro, the development and improvement of new techniques and methods for intensifying of the process of microclonal reproduction of sanitized potato primary seed material is of a particular relevance. It is established that the maximum productivity and outpay of the investments is provided by the cultivation of the early-ripening potato variety Kobza at the 
temperature of $14-16^{\circ} \mathrm{C}$ and the light intensity of $30001 \mathrm{x}$; of the middle-early potato variety Nevska: with the illumination of 16 hours, the cultivation temperature of $18-200 \mathrm{C}$, the substitution of the full nutrient medium Murashige, Skoog (MS) on the 20th day of the cultivation on the medium with a half of the norm of nitrogen. The number of microtubers per plant is 1.2 and $1.2 \mathrm{pc}$., the mass of an average microtuber is 262.0 and $247.6 \mathrm{mg}$, and the microtubers mass per plant is 363.7 and $283.2 \mathrm{mg}$, respectively.

\section{REFERENCES}

1. Бугаєва I. П., Сніговий В. С. Культура картоплі на півдні України : монографія. Херсон, 2002. 176 с.

2. Коновалова Г. И., Бобрик А. О., Семенова 3. А. Производство исходного семенного материала. Картофелеводство: науч. тр. БНИИКХ, 2000. Вып. 10. С. 215-221.

3. Cassels A. C. In vitro induction of virus - free potatoes by chemotherapy. Biotechnology in Agriculture and Forestry (3). Potato. Berlin, 1987. P. 40-50.

4. Бондарчук А. А. Наукові основи насінництва картоплі в Україні : монографія. Біла Церква, 2010. 400 с.

5. Куценко В. С., Осипчук А. А., Подгаєцький А. А. [та ін.]. Методичні рекомендації щодо проведення досліджень 3 картоплею. Немішаєве : Ін-т картопл., 2002. 183 с.

6. Вожегова Р. А., Лавриненко Ю. О., Балашова Г. С. [та ін.]. Оздоровлення картоплі в культурі in vitro: науково-методичні рекомендації. Херсон, Ін-т зрош. землероб., 2013. 20 с.

7. Лавриненко Ю. А., Балашова Г. С., Котова Е. И. Продуктивность растений картофеля в культуре меристем in vitro. Оралдын гылым жаршысы (Уральский научный вестник). 2015. № 12(143). С. 34-38.

\section{Information about the author:} Balashova H. S., Doctor of Agricultural Sciences, Senior Researcher, Head of Potato Biotechnology Laboratory, Institute of Irrigated Agriculture of the National Academy of Agrarian Sciences of Ukraine Kherson, Naddnipryanske, 73483, Ukraine 


\section{SYSTEMS OF BASIC TILLAGE \\ IN THE CROP ROTATIONS ON THE IRRIGATED LANDS OF SOUTHERN STEPPE OF UKRAINE}

\section{Biliaieva I. M.}

\section{INTRODUCTION}

The Steppe zone occupies southern part of the territory of Ukraine. The area of agricultural land is 17.617 million ha, of which 14.848 million ha of arable land.

Southern arid and Dry Steppe soil and ecological subzones of the Steppe zone occupy 5 million 761 thousand agricultural lands in five regions of Ukraine and Crimea, of which arable land occupies 4 million 507 thousand ha or $78.2 \%$. The soil cover is represented by chernozem southern and chestnut soils. The main area of chernozem southern $-62.6 \%$ is occupied by model subtypes, $22.2 \%$ - micelle-carbonate, $15.1 \%$ - alkaline, $25 \%$ eroded. The soils of the chestnut zone are divided into dark-chestnut and chestnut. The latter occupy a narrow strip along the Sivash with a total area of 219.4 thousand ha. To the north of the chestnut soils are dark-chestnut soils with a total area of 1270 thousand ha ${ }^{1}$.

Experimental studies were carried out in the Bilozerka naturalagricultural district of Kherson region.

The soil cover of the district is represented by dark-chestnut soils and their complexes with solonetz. They occupy $69.7 \%$ of arable land. The soils are characterized by a developed humus profile with a thickness of $52-58 \mathrm{~cm}$, a low content of humus $(1.9-2.7 \%)$, medium and heavy-loamy granulometric composition, deflation-safe, chemical and physical properties are satisfactory. On the lands irrigated from the Dnipro estuary and the Ingulets river, secondary alkalination, places of salinization and flooding of the soils are manifested ${ }^{2,3,4,5}$.

\footnotetext{
${ }_{1}^{1}$ Класифікація грунтів України. К.: Аграрна наука, 2005. 299 с.

${ }^{2}$ Система ведення сільського господарства Херсонської області. Херсон: «Айлант», 2004. $164 \mathrm{c}$.

${ }^{3}$ Балюк С. А., Ромащенко М. І., Трускавецький Р. С. Меліорація грунтів систематика, перспективи, інновації. Херсон, 2015. 667 с.

${ }_{4}^{4}$ Коваленко П. І. Інтегроване управління водними і земельними ресурсами на меліорованих територіях. Київ: Аграрна наука, 2009. 783 с.

5 Ромащенко М. І., Вожегова Р. А., Шатковський А. П. Наукові засади розвитку аграрного сектора економіки південного регіону. Херсон: Олді- плюс, 2017. 437 с.
} 
The territory of the district is located in the northern part of the Black Sea lowland on the right bank of the Dnipro River within the Upper Pliocene terrace.

Geologically, the upper terraces are composed of four horizons of loessloam thickness of $25-30 \mathrm{~m}$, dissected by 2-3 horizons of buried soils. The forests are covered by red-brown clays that lie on Neogene Pontic lime stones. Sandy and clay deposits occur between lime stones and clays ${ }^{6,7}$.

The lands of the Central experimental base of the Institute of Irrigated Agriculture of NAAS are located in eastern part of the Bilozerka district of Kherson region in the area of Ingulets irrigation system.

The soil of the experimental plot is a dark-chestnut middle-loamy secondary-alkaline silt-stone one. The granulometric composition of the studied soil is mainly represented by the large dust fraction $(38.1 \%$ in the arable layer), so they are easily susceptible to erosion processes (Table 1).

Table 1

Granulometric composition of the dark-chestnut soil of the experimental field of the Institute of Irrigated Agriculture of NAAS

\begin{tabular}{|c|c|c|c|c|c|c|c|c|c|c|}
\hline \multirow{2}{*}{$\begin{array}{l}\text { Genetic } \\
\text { horizon }\end{array}$} & \multirow{2}{*}{$\begin{array}{l}\text { Depth } \\
\text { of } \\
\text { sample } \\
\text { taking, } \\
\text { cm }\end{array}$} & \multirow{2}{*}{$\begin{array}{l}\text { Hygroscopic } \\
\text { humidity, \% }\end{array}$} & \multicolumn{6}{|c|}{ Fractions, $\mathbf{m m}$} & \multicolumn{2}{|c|}{$\begin{array}{c}\text { Sum of } \\
\text { particles, } \mathrm{mm}\end{array}$} \\
\hline & & & $\begin{array}{c}1- \\
0.25\end{array}$ & $\begin{array}{c}0.25- \\
0.05\end{array}$ & $\begin{array}{l}0.05- \\
0.01\end{array}$ & $\begin{array}{l}0.01- \\
0.005\end{array}$ & $\begin{array}{l}0.005- \\
0.001\end{array}$ & $<0.001$ & $<0.01$ & $>0.01$ \\
\hline $\begin{array}{l}\mathrm{H}(\mathrm{e}) \\
\text { arable }\end{array}$ & $10-20$ & 1.06 & 0.80 & 21.44 & 38.10 & 13.95 & 4.89 & 20.82 & 39.66 & 60.34 \\
\hline Hpi & $35-45$ & 1.10 & 0.16 & 17.74 & 41.84 & 11.59 & 5.85 & 22.82 & 40.26 & 59.74 \\
\hline $\mathrm{Phi} / \mathrm{K}$ & $48-52$ & 1.08 & 0.25 & 7.94 & 40.59 & 14.26 & 10.07 & 26.89 & 51.22 & 48.78 \\
\hline $\mathrm{Pi} / \mathrm{K}$ & $55-65$ & 1.08 & 0.32 & $\begin{array}{l}8.74 \\
\end{array}$ & 30.72 & 15.90 & 11.60 & 32.72 & 60.22 & 39.78 \\
\hline $\mathrm{P} / \mathrm{\kappa}$ & $70-80$ & 1.07 & 0.40 & 7.10 & 31.20 & 16.20 & 12.20 & 32.90 & 61.30 & 38.70 \\
\hline
\end{tabular}

Due to the fact that irrigation of the experimental plot was carried out by the waters of low mineralization with an unfavorable ratio of one - and divalent cations (irrigation waters of the Ingulets irrigation system according to the DSTU-2730-94 belong to the 2nd class - «limited suitable for irrigation»), there was observed an increased content of exchangeable sodium in the soil absorption complex of the arable layer in comparison to the non-irrigated soil.

Soil alkalinity determines unsatisfactory water-physical properties of the arable layer. The low content of water-resistant aggregates in the arable layer of the soil complicates its cultivation in the dry conditions. Under irrigation,

${ }^{6}$ Бурзі К. Е., Красутська Н. В., Синицина Н. П., Сафонова О. П.Сольовий режим грунтів Інгулецького зрошуваного масиву. Зрошуване землеробство. 1971. Вин. 12. С. 63-67.

${ }_{7}^{7}$ Балюк С. А., Ромащенко М. І., Сташук В. А. Наукові основи охорони та раціонального використання зрошуваних земель України. Київ: Аграрна наука, 2009. 620 с. 
the surface layer over-crusts, which impedes the penetration of water into the deeper horizons of the soil. The condition of the physical maturity of the alkaline soil, which determines its suitability for cultivation in the spring, is delayed, and after cultivation - lumpy surface is formed. The clods in the dry state are strong, difficult to cultivate, in addition, in such soils at the depth of 30-35 cm, a compacted illuvial layer is formed, which impedes the penetration into the deeper layers not only for water but also for the root system of plants. Thus, dark-chestnut soils under the irrigation with the waters of the Ingulets Irrigation System require anti-erosion measures and the development and improvement of their tillage with accordance to the certain conditions of the area.

The development of the system of basic tillage of the secondary-gleied irrigated, on the background of closed horizontal drainage, lands was carried out on meadow-chestnut medium-solod gley on the gleied loess soils. Their general characteristics correspond to the soils described above. Agrochemical composition of the general forms of nitrogen, phosphorus and potassium, they are close to the dark-chestnut soils.

Thus, the dark-chestnut secondary-alkaline and chernozem southern moderately-washed soils by physical, chemical and physic-chemical properties are typical soils of the meliorated agro-landscapes of Southern Steppe of Ukraine.

On the central experimental base of the Institute of Irrigated Agriculture of NAAS, a study devoted to the determination of the impact of basic tillage systems on agro physical, chemical and biological soil properties, phytosanitary conditions of crops, yields and productivity of various types of irrigated and non-irrigated crop rotations have been started since 1966.

The results of the studies, obtained in the first rotation (1966-1976) of fruit-changing crop rotation on the dark-chestnut irrigated middle-loamy soil, indicate that for 10 years of irrigation with the use of five tillage systems with a rotation of the slice to the depth of $20-22$ to $38-40 \mathrm{~cm}$ there was an increase in the content of organic matter in the soil layer of $0-40 \mathrm{~cm}$ to $111.4-111.8$ t/ha with the content of $1.97 \%$, i.e. the average annual increase averaged to $0.71-0.75 \mathrm{t} / \mathrm{ha}$.

\section{Tillage systems in the crop rotations for enterprises with developed dairy and beef cattle}

Irrigation is the most effective measure to counteract the increasing aridity of climate, especially in southern part of the Steppe zone. Approaches to tillage in crop rotations on the irrigated lands differ significantly from those on the non-irrigated ones, and they are directed to the improvement of the water regime and ensuring ecological safety at the realization of the 
natural and climatic potential of the region and genetically determined productivity of varieties and hybrids of crops ${ }^{8,9}$.

Combination for a long time in fruit-changing crop rotation with the coefficient of use of irrigated arable land of 1.25 of the deep plow tillage under the row crops - corn for grain and silage, sugar and forage beetroots, soybean, vegetable crops and alfalfa, with shallow $(12-14 \mathrm{~cm})$ disk loosening under the cereals - winter wheat, winter barley, winter rye and surface $(6-8 \mathrm{~cm})$ or sowing in the previously untilled soil in the post-harvest and post-mowing terms promoted nitrogen mobilization to a greater extent than the long-termed plowless tillage. At the differentiated system of tillage in crop rotation in comparison to the plowless shallow single-depth one $(12-14 \mathrm{~cm})$ the bulk density decreased by $6.3 \%$, the water permeability increased from 1.68 to $2.28 \mathrm{~mm} / \mathrm{min}$. (35.7\%), the content of waterproof units increased by $9.2 \%$.

Wrapping of plant residues or manure under plowing into the lower part of the cultivated layer in this crop rotation provided a higher level of humification process than introducing fresh organic matter into the top $(0-15 \mathrm{~cm})$ soil layer under plowless tillage systems, as evidenced by the results of the long-term experimental researches.

In the 8-field grain-herb-row crop rotation on the background of generally accepted irrigation regimes and organo-mineral fertilization system with the application of N180P120 and 15 tons of semi-rotten manure per 1 ha of the crop rotation contributed to the average annual increase of humus at the level of 1.28-1.57 t/ha, whereas at the long-term use (1976-2006) of the system of single-depth shallow tillage in the crop rotation the accumulation was only $0.85 \mathrm{t} / \mathrm{ha}^{10,11,12}$.

During the fifth rotation (2007-2016), alfalfa and multicomponent herb mixtures for green manure in the post-harvest period were excluded from the crop rotation, and the entire leaf-stem mass of the crop rotation was used for fertilization. As a result, the tempo of humus accumulation over this 10-year

${ }^{8}$ Вожегова Р. А., Сташук В. А., Заришняк А. С. Системи землеробства на зрошуваних землях. Київ: Аграрна наука, 2014. 359 с.

${ }_{9}^{9}$ Малярчук М. П., Нижеголенко В. М., Резніченко Н. Д., Воронюк Л. А. Системи землеробства в умовах південного посушливого та сухого степу. Збірник матеріалів Міжнародної науково-практичної конференції «Наукові засади ефективного ведення степового землеробства в умовах змін клімату» 28-29 травня 2015 р. Херсон: Грінь Д.С., 2015. C. 141-145.

${ }^{10}$ Малярчук М. П., Вожегова Р. А., Марковська О. Є. Формування систем основного обробітку грунту в агробіоценозах на меліорованих землях південної посушливої та сухо степової грунтово-екологічних підзон України. Навчальний посібник. Херсон: Айлант, 2012. $180 \mathrm{c}$.

${ }^{11}$ Малярчук М. П., Писаренко П. В., Мишукова Л. С., Малярчук А. С Котельников Д. І., Нижеголенко В. М. Ефективність мінімізованих способів основного обробітку і сівби в попередньо-необроблений грунт при вирощуванні кукурудзи на зрошуваних землях. Зрошуване землеробство: збірник наукових праць. Херсон: Айлант, 2013. Вип. 59. С. 36-38.

12 Малярчук М. П. Система обробітку грунту. Наукові основи охорони та раціонального використання зрошуваних земель України. Київ: Аграрна наука, 2009. C. 299-313. 
time span decreased in all the variants of the experiment and averaged to 0.1-0.3 t/ha, with the highest rate in the variant of the differentiated basic tillage system, where differentiated by depth plowless methods are interchanged with one slotting for the crop rotation on the depth of $38-40 \mathrm{~cm}$ during the rotation (Fig. 1).

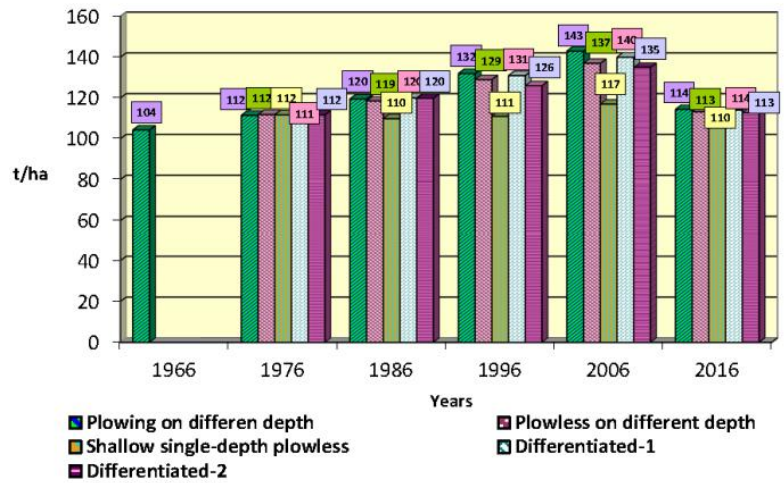

Fig. 1. Dynamics of the humus content in the $0-40 \mathrm{~cm}$ layer of dark-chestnut soil under different systems of basic tillage in 8-field fruit-changing irrigated crop rotation for the period of 1966-2016, $t / \mathrm{ha}$

In general, experimental studies of the efficiency of different systems of basic tillage of dark-chestnut soil provided the possibility to find out that the highest productivity of the eight-crop fruit-changing rotation is provided by the differentiated system of basic tillage, in which the plowing to the depth of 20-22 to 30-32 cm under the row crops inter-changes with plowless tillage to the depth of 12-16 cm under winter wheat and spring barley on the background of one slotting $(38-40 \mathrm{~cm})$ for the rotation under barley with alfalfa.

The use of the differentiated basic tillage system increased the cost recovery by $9.4 \%$ due to the increase in the crop rotation productivity up to $13.0 \mathrm{t} / \mathrm{ha}$ of forage units against $11.5 \mathrm{t} / \mathrm{ha}$ of forage units at the plowless single-depth shallow $(12-14 \mathrm{~cm})$ system of basic tillage (Table 2). 
Table 2

\section{Productivity of 8-field fruit-changing crop rotation at irrigation under the different systems of basic tillage of dark-chestnut soil of the experimental field of the Institute of Irrigated Agriculture of NAAS}

\begin{tabular}{|c|c|c|c|c|c|}
\hline \multirow{2}{*}{ Crop of the rotation } & \multicolumn{5}{|c|}{ Productivity by the systems, $t / h a$ of forage units } \\
\hline & 1 & 2 & 3 & 4 & 5 \\
\hline $\begin{array}{c}\text { Annual crops } \\
\text { for green forage }+ \text { alfalfa (hay) }\end{array}$ & 13.6 & 13.1 & 12.3 & 13.6 & 13.2 \\
\hline Alfalfa of the $2^{\text {nd }}$ year (hay) & 12.1 & 12.1 & 12.2 & 12.0 & 12.1 \\
\hline Alfalfa of the $3^{\text {nd }}$ year (hay) & 9.8 & 8.4 & 8.4 & 9.7 & 8.3 \\
\hline Winter wheat + post-harvest & 6,9 & 71,5 & 70,8 & 71,2 & 70,3 \\
\hline (grain + green mass) & $\overline{39,2}$ & $\overline{402}$ & $\overline{376}$ & $\overline{400}$ & $\overline{399}$ \\
\hline Sugar-beet & 6.6 & 5.9 & 5.5 & 6.9 & 6.6 \\
\hline Corn for silage & 45.6 & 42.3 & 38.3 & 46.6 & 47.1 \\
\hline Winter wheat + post-harvest & 65,9 & 70,2 & 72,9 & 68,3 & 67,1 \\
\hline (grain + green mass $)$ & $\overline{492}$ & $\overline{517}$ & $\overline{505}$ & $\overline{499}$ & $\overline{482}$ \\
\hline Grain corn & 8.9 & 7.7 & 7.5 & 9.1 & 8.7 \\
\hline $\begin{array}{l}\text { Crop rotation productivity, } \\
\text { forage units }\end{array}$ & 12.8 & 11.8 & 11.5 & 13.0 & 12.6 \\
\hline
\end{tabular}

Note: 1-plowing at different depth, 2-plowless at different depth, 3-shallow single-depth plowless, 4-differentiated-1 with plowing under the row crops and one slotting per rotation, 5-differentiated-2 with plowing under the row crops

The increase of the coefficient of arable land use in the irrigated crop rotations up to 1.75 at the expense of inter-crops in early spring, post-mowing and post-harvest periods makes it possible to increase the efficiency of irrigated hectare and to obtain more products at the same costs for the construction of irrigation network and its exploitation, as well as provides additional accumulation of organic matter, which improves the physical and chemical properties of the soil and activates beneficial microorganisms activity. Owing to inter-crops of leguminous and cabbage crops, nitrogen reserves are increasing, and the weediness of the following crops is reduced ${ }^{3}$.

In the arable soil layer, after sowing of the inter-crops, where the recommended irrigation regime has been maintained, there is sufficient water for its qualitative preparation to sowing. The decisive value for the crops cultivation in the post-mowing and post-harvest periods is not the depth, but the quality of pre-sowing tillage, that is, good seed wrapping and sufficient compaction of the seed bed for better provision with water of the crops with large seeds.

Taking into account that their growth and development is limited in time, it is advisable to observe these conditions. Compliance with the necessary agrotechnical requirements enables the use of combined tillage aggregates for simultaneous tillage, sowing and rolling.

${ }_{13}$ Малярчук М. П. Формування систем обробітку грунту в сівозмінах на меліорованих землях Південного Степу України. Посібник Українського хлібороба. 2014. 
As a result of the introduction of differentiated system of basic tillage in the 4-field row crop rotation with the coefficient of use of irrigated arable land of 1.75 , the high efficiency of its saturation with early spring, postmowing and post-harvest crops has been established.

The loosening effect of the root system, the protective effect of the vegetative mass of plants in the spring and summer period and the effect of post-harvest residues of inter-crops, directed to the soil improvement, contributed to the reduction of the bulk density of dark-chestnut soil in the layer of $0-30 \mathrm{~cm}$ from 1.28 to $1.14-1.19 \mathrm{~g} / \mathrm{cm}^{3}$, or $11.0-8.0 \%$ to the optimum values for cereals and row crops.

The highest yield, and correspondingly, the productivity of the crop rotation, was provided by the differentiated tillage, in which the deep plowing under sugar-beet inter-changes with the plowless shallow and surface tillage for intermediate early spring mixtures, winter barley, postmowing crops of grain corn and sunflower, with sowing of corn for forage in the previously unprepared soil after winter barley (Table 3 ).

Table 3

Productivity of 4-field row forage crop rotation at irrigation under the different methods of basic tillage of dark-chestnut soil of the experimental field of the Institute of Irrigated Agriculture of NAAS

\begin{tabular}{|c|c|c|c|c|c|c|}
\hline \multirow{2}{*}{ Field } & \multirow{2}{*}{ Crop } & \multicolumn{4}{|c|}{ Productivity by the systems, $t /$ ha } & \multirow{2}{*}{$\begin{array}{c}\mathbf{L S D}_{05}, \\
\text { t/ha }\end{array}$} \\
\hline & & 1 & 2 & 3 & 4 & \\
\hline \multirow[b]{2}{*}{1} & Annual herb mixtures & 32.4 & 33.9 & 33.9 & 34.5 & 2.9 \\
\hline & Post-mowing sunflower (seed) & 3.0 & 2.8 & 3.0 & 3.2 & 0.24 \\
\hline \multirow{2}{*}{2} & Annual herb mixtures & 31.1 & 31.4 & 32.3 & 32.5 & 2.6 \\
\hline & Post-mowing corn for forage & 38.9 & 40.6 & 42.6 & 40.9 & 3.0 \\
\hline \multirow[b]{2}{*}{3} & Winter barley (grain) & 4.2 & 4.4 & 4.4 & 4.2 & 0.3 \\
\hline & $\begin{array}{l}\text { Post-harvest corn for green } \\
\text { forage }\end{array}$ & 37.5 & 41.1 & 40.8 & 39.3 & 3.0 \\
\hline \multirow[t]{2}{*}{4} & Sugar-beet & 52.0 & 53.3 & 56.1 & 55.8 & 3.6 \\
\hline & $\begin{array}{l}\text { Crop rotation productivity, t/ha } \\
\text { of forage units }\end{array}$ & 13.8 & 14.24 & 14.7 & 14.6 & - \\
\hline
\end{tabular}

Note: 1-plowing at different depth, 2-plowless at different depth, 3-differentiated with slotting, 4-differentiated with plowing under the row crops.

\section{Systems of tillage in the crop rotation}

\section{for the enterprises working for the industrial processing}

During 2007-2018, on the background of continuous application of five basic tillage systems and three organo-mineral fertilizer systems, using as the fertilizer of leaf-stem mass of the crops of the crop rotation, the least experimentally studied and scientifically substantiated row crop rotations were investigated, which were found at the enterprises specializing in the production of cereals and industrial crops for industrial processing. Today, among the total are of the irrigated lands of 510 thousand ha, 265 thousand ha are covered by the row crops, which is $52.0 \%$. 
In these newly established large-scale enterprises, where there is no livestock industry, short crop rotations with soybean, corn for grain and sunflower have the priority. Cereal and perennial herbs occupy $10-15 \%$ of the croplands.

Crops, which are the part of row crop rotations, have different requirements for agro-physical properties and nutritional regimes, which are formed mainly under the influence of basic tillage and fertilization systems.

Nowadays, leaf-stem and root post-harvest residues of crops are the main source of fresh organic matter for the soil, which under the activity of microorganisms; oxidation and polymerization processes are transformed into new substances that are contained neither in the input organic residues, nor in microorganisms. According to the results of the research, it is established that on the non-fertilized background every year 4.0 to 4.8 tons of post-harvest residues are incorporated into the soil per 1 ha of the crop rotation area, on the background $-\mathrm{N}_{82.5} \mathrm{P}_{60}$ from 7.4 to 8.3 tons, and on the background of $\mathrm{N}_{120} \mathrm{P}_{60}$ application from 7.5 to $9.4 \mathrm{t} / \mathrm{ha}$.

Calculations of humus income into the soil from incorporated postharvest residues under the different basic tillage systems and nutrition background indicate that a negative humus balance is formed for all tillage systems, while the highest values were at plowless single-depth shallow $0.33 \mathrm{t} / \mathrm{ha}$ and the smallest $-0.16 \mathrm{t} / \mathrm{ha}$ for the differentiated-1 tillage with slotting on the depth of $38-40 \mathrm{~cm}$ once per rotation.

On the fertilized backgrounds with the application of $\mathrm{N}_{82.5} \mathrm{P}_{60}$ and $\mathrm{N}_{120} \mathrm{P}_{60}$ there was an increase in humus content. In the variants of multi-depth plow and differentiated-1 systems of the basic tillage, the increase of humus content was $+0.78 \mathrm{t} / \mathrm{ha}$, while under the plowless on different depth it was lower by $14.1 \%$ and was $+0.68 \mathrm{t} / \mathrm{ha}$.

At the systems of single-depth shallow plowless tillage and the differentiated-2, the humus content increase was also positive, while it was lower in comparison to the control by 51.3 and $38.5 \%$, respectively, at +0.38 and $+0.48 \mathrm{t} / \mathrm{ha}$.

To compensate the uptake of mineral nutrients with the crops, there was an input of total nitrogen, phosphorus and potassium into the soil with root and leaf residues. Thus, on a non-fertilized background, with basic plow tillage on the different depth (control), there was an income to the soil of $\mathrm{N}-21.8 ; \mathrm{P}_{2} \mathrm{O}_{5}-10.9 ; \mathrm{K}_{2} \mathrm{O}-26.7 \mathrm{~kg}$, and for the differentiated -1 with one slotting on $38-40 \mathrm{~cm}$ for the rotation $-\mathrm{N}-22 \mathrm{~kg} ; \mathrm{P}_{2} \mathrm{O}_{5}-11.0 ; \mathrm{K}_{2} \mathrm{O}-$ $26.4 \mathrm{~kg}$ per hectare of the crop rotation area. A similar tendency was observed on the fertilized backgrounds, while at the same time the indexes of mineral nutrition income were significantly higher.

At the application of the dose of $\mathrm{N}_{82.5} \mathrm{P}_{60}$, the income of nitrogen, phosphorus and potassium into the soil with plant residues was $70-80 \%$ higher than on the non-fertilized background.

Nitrogen, phosphorus and potassium income into the soil at the doses of $\mathrm{N}_{120} \mathrm{P}_{60}$ application averaged at the plow tillage on different depth to, 
respectively: $\mathrm{N}-42.6 \mathrm{~kg} / \mathrm{ha} ; \mathrm{P}_{2} \mathrm{O}_{5}-21.3$ and $\mathrm{K}_{2} \mathrm{O}-51.1 \mathrm{~kg} / \mathrm{ha}$, that is 91.4-95.4\% more than in the non-fertilized background (control).

At the multi-depth plowless and differentiated-1 systems of the basic tillage, the reduction of mineral nutrition inputs in comparison to the control was not significant and averaged to $1.8 \%, 1.5$ and $1.7 \%$.

Only under the system of single-depth shallow plowless tillage with its long application in the crop rotation and on all the fertilization backgrounds, there was a significant decrease in the income of all mineral nutrients in comparison to the system of plow tillage on different depth.

In general, the application of mineral fertilizers and the use of postharvest (leaf and stem) residues as fertilizers contributed to the creation of different levels of content of available forms of mineral nutrients at the beginning of the spring regrowth of winter crops and emergence of spring cereals and industrial crops seedlings.

At the non-fertilized background with the use of post-harvest residues as a fertilizer at the beginning of vegetation of the crops of the crop rotation, the highest content of mobile mineral nutrition compounds was in the variant of the plowing basic tillage system: nitrates $29.8 \mathrm{mg} / \mathrm{kg}$ of soil, mobile phosphorus of 31.8 and exchangeable potassium of $289 \mathrm{mg} / \mathrm{kg}$ of soil.

The application of mineral fertilizers with the dose of $\mathrm{N}_{82.5} \mathrm{P}_{60}$ ensured the increase in the content of all the elements of mineral nutrition, while at the same time the advantage remained at the system of differentiated by the depth plowing.

The highest nitrate content of $68.4 \mathrm{mg} / \mathrm{kg}$ of soil, mobile phosphorus of 46.4 and exchangeable potassium of $358 \mathrm{mg} / \mathrm{kg}$ of soil was formed under the application of mineral fertilizers with the dose of $\mathrm{N}_{120} \mathrm{P}_{60}$ per hectare of the crop rotation area under the multi-depth plow system of tillage.

Multi-depth plowless and differentiated tillage systems provided close performance with the multi-depth plow tillage system, and only the single-depth shallow plowless loosening system led to a significant decrease in the content of available mineral nutrients in the soil layer of $0-40 \mathrm{~cm}$ at the beginning of the spring vegetation of the crops of the rotation.

Before the harvesting, the nitrate content of the soil decreased on all the nutritional backgrounds, while at the same time the smallest indexes were on the non-fertilized background.

It should be mentioned that the basic tillage affected the content of mobile phosphorus and exchangeable potassium. It was the lowest at the plowless shallow single-depth tillage and reached $27.9-38.3$ and $259-315 \mathrm{mg} / \mathrm{kg}$ at the beginning of the growing season and 18.7-21.9 and $214-254 \mathrm{mg} / \mathrm{kg}$ of the soil, respectively, before the harvesting. Before the harvesting, their content reduced and remained within the range of moderate supply.

Analyzing the crop productivity data in the crop rotation on the non-fertilized background it was found that its highest values, expressed in the grain units per $1 \mathrm{ha}$ of the crop rotation area, were obtained at the plowing tillage on the different depth -3.95 , and differentiated- $1-4.11 \mathrm{t} / \mathrm{ha}$ of grain units. 
Under the use of the different-depth plowless tillage and the differentiated-2 basic tillage, slightly lower yields of grain units of 3.56 and $3.47 \mathrm{t} / \mathrm{ha}$ were obtained. A significant decrease in productivity by $27.8 \%$ in comparison to the control was observed in the variant of shallow singledepth plowless tillage (table. 4).

Table 4

Crop yields and productivity of 4-field crop rotation at irrigation at different fertilizer doses and basic tillage systems

\begin{tabular}{|c|c|c|c|c|c|c|}
\hline \multirow[b]{2}{*}{$\begin{array}{c}\text { Basic tillage } \\
\text { system } \\
\text { (factor A) }\end{array}$} & \multirow[b]{2}{*}{$\begin{array}{l}\text { Fertilizers dose } \\
\quad \text { (factor B) }\end{array}$} & \multicolumn{4}{|c|}{ Yield, t/ha } & \multirow[b]{2}{*}{$\begin{array}{c}\text { Productivity } \\
\text { in grain units, } \\
\text { t/ha }\end{array}$} \\
\hline & & $\begin{array}{l}\text { winter } \\
\text { wheat }\end{array}$ & $\begin{array}{c}\text { grain } \\
\text { corn }\end{array}$ & soybean & $\begin{array}{c}\text { grain } \\
\text { sorghu } \\
\text { m }\end{array}$ & \\
\hline \multirow{3}{*}{$\begin{array}{c}\text { Plow } \\
\text { (control) }\end{array}$} & $\begin{array}{c}\text { no fertilizers } \\
\text { (control) }\end{array}$ & 3.15 & 4.26 & 2.76 & 2.89 & 3.95 \\
\hline & $\mathrm{N}_{82.5} \mathrm{P}_{60}$ & 6.01 & 11.43 & 3.68 & 6.90 & 8.05 \\
\hline & $\mathrm{N}_{120} \mathrm{P}_{60}$ & 6.81 & 14.44 & 4.34 & 7.09 & 9.36 \\
\hline \multirow{3}{*}{$\begin{array}{l}\text { Plowless on } \\
\text { different depth }\end{array}$} & $\begin{array}{c}\text { no fertilizers } \\
\text { (control) }\end{array}$ & 3.01 & 3.81 & 2.48 & 2.51 & 3.56 \\
\hline & $\mathrm{N}_{82.5} \mathrm{P}_{60}$ & 5.53 & 10.81 & 3.34 & 6.58 & 7.55 \\
\hline & $\mathrm{N}_{120} \mathrm{P}_{60}$ & 6.25 & 13.64 & 3.98 & 6.81 & 8.78 \\
\hline \multirow{3}{*}{$\begin{array}{c}\text { Plowless } \\
\text { single-depth }\end{array}$} & $\begin{array}{c}\text { no fertilizers } \\
\text { (control) }\end{array}$ & 2.70 & 3.05 & 1.77 & 2.04 & 2.85 \\
\hline & $\mathrm{N}_{82.5} \mathrm{P}_{60}$ & 5.26 & 8.16 & 2.41 & 4.59 & 5.82 \\
\hline & $\mathrm{N}_{120} \mathrm{P}_{60}$ & 5.91 & 10.08 & 2.83 & 4.76 & 6.70 \\
\hline \multirow{3}{*}{ Differentiated-1 } & $\begin{array}{c}\text { no fertilizers } \\
\text { (control) }\end{array}$ & 3.24 & 4.46 & 2.81 & 3.03 & 4.11 \\
\hline & $\mathrm{N}_{82.5} \mathrm{P}_{60}$ & 6.08 & 11.81 & 3.79 & 7.51 & 8.50 \\
\hline & $\mathrm{N}_{120} \mathrm{P}_{60}$ & 6.90 & 14.82 & 4.31 & 7.70 & 9.75 \\
\hline \multirow{3}{*}{ Differentiated-2 } & $\begin{array}{l}\text { no fertilizers } \\
\text { (control) }\end{array}$ & 2.89 & 3.73 & 2.40 & 2.54 & 3.47 \\
\hline & $\mathrm{N}_{82.5} \mathrm{P}_{60}$ & 5.34 & 10.28 & 3.37 & 6.28 & 7.28 \\
\hline & $\mathrm{N}_{120} \mathrm{P}_{60}$ & 6.13 & 13.01 & 3.94 & 6.43 & 8.46 \\
\hline
\end{tabular}

The productivity of the crops by the variants of the ways and depth of the basic tillage at the application of mineral fertilizers with the dose of $\mathrm{N}_{82.5} \mathrm{P}_{60}$ increased to $112.1 \%$, and the increase of the dose of fertilizers to $\mathrm{N}_{120} \mathrm{P}_{60}$ ensured its raise to $146.6 \%$, compared to the non-fertilized backgrounds.

The increase of the dose of mineral fertilizers on the background with the application of N120P60 was favorable for the growth of productivity by $14.7-16.3 \%$ in comparison to the N82.5P60 nutritive background.

In the structure of the expenditures for cultivation its share varies from 2 to $10 \%$, while at the same time it largely depends on the productivity of most crops on irrigated lands. Assessing the effectiveness of low-cost, shallow and multidepth soil tillage systems in the crop rotation, it should be noted that having provided significant cost savings for their implementation, they have little impact on the overall expenditures for crop production on the whole. So, if on a non-fertilized background at the systems of different-depth plowing basic tillage (control), the expenditures for cultivation technology averaged to 10.47 thousand 
UAH per hectare of the crop rotation area, then for the systems of different-depth plowless tillage and differentiated-1 with one slotting per the rotation and differentiated-2 with one plowing per the rotation (variants $2,4,5$ ), they were less by $1.5,2.1$ and $2.3 \%$, respectively.

At the single-depth shallow plowless tillage system (variant 3), expenditures have decreased by $3.0 \%$. The cost of gross production per hectare of the crop rotation area for various plowing systems on the nonfertilized background was 17.74 thousand UAH. In the variant of the differentiated-1 basic tillage system, it was higher and averaged to 18.61 thousand UAH, or increased by $4.9 \%$ with a profitability level of 71.4 and $82.9 \%$, respectively.

The lowest payback of crop cultivation technology in the irrigated crop rotation was on the unfavorable background of the single-depth shallow plowless tillage system, with a gross output of 12.65 thousand UAH, which is lower than the control by $28.7 \%$ with a profitability level of $26.4 \%$ (Table 5).

Table 5

Economic efficiency of crop cultivation technologies under different tillage and fertilizer systems

\begin{tabular}{|c|c|c|c|c|c|c|}
\hline № & $\begin{array}{l}\text { Basic tillage } \\
\text { system in the } \\
\text { crop rotation }\end{array}$ & $\begin{array}{c}\text { Fertilizers } \\
\text { dose }\end{array}$ & $\begin{array}{c}\text { Gross } \\
\text { product } \\
\text { value }\end{array}$ & $\begin{array}{l}\text { Expendit } \\
\text { ures, } \\
\text { UAH }\end{array}$ & $\begin{array}{l}\text { Profit, } \\
\text { UAH/ha }\end{array}$ & $\begin{array}{c}\text { Profitabilit } \\
\text { y, \% }\end{array}$ \\
\hline \multirow[t]{3}{*}{1} & \multirow{3}{*}{$\begin{array}{c}\text { Plow } \\
\text { (control) }\end{array}$} & $\begin{array}{c}\text { no } \\
\text { fertilizers } \\
\text { (control) }\end{array}$ & $17,743.0$ & $10,470.7$ & $7,272.3$ & 71.4 \\
\hline & & $\mathrm{N}_{82.5} \mathrm{P}_{60}$ & $34,984.3$ & $13,827.3$ & $21,157.0$ & 152.7 \\
\hline & & $\mathrm{N}_{120} \mathrm{P}_{60}$ & $40,752.7$ & $15,016.3$ & $25,736.0$ & 170.5 \\
\hline \multirow[t]{3}{*}{2} & \multirow{3}{*}{$\begin{array}{l}\text { Plowless on } \\
\text { different depth }\end{array}$} & $\begin{array}{c}\text { no } \\
\text { fertilizers } \\
\text { (control) }\end{array}$ & $16,119.0$ & $10,312.3$ & $5,806.7$ & 57.9 \\
\hline & & $\mathrm{N}_{82.5} \mathrm{P}_{60}$ & $32,757.0$ & $13,631.7$ & $19,125.3$ & 140.3 \\
\hline & & $\mathrm{N}_{120} \mathrm{P}_{60}$ & $38,285.3$ & $14,832.7$ & $23,452.7$ & 157.5 \\
\hline \multirow[t]{3}{*}{3} & \multirow{3}{*}{$\begin{array}{l}\text { Plowless single- } \\
\text { depth }\end{array}$} & $\begin{array}{c}\text { no } \\
\text { fertilizers } \\
\text { (control) }\end{array}$ & $12,654.0$ & $10,155.7$ & $2,498.3$ & 26.4 \\
\hline & & $\mathrm{N}_{82.5} \mathrm{P}_{60}$ & $25,479.3$ & $13,494.3$ & $11,985.0$ & 89.4 \\
\hline & & $\mathrm{N}_{120} \mathrm{P}_{60}$ & $29,008.3$ & $14,701.3$ & $14,307.0$ & 97.1 \\
\hline \multirow[t]{3}{*}{4} & \multirow[t]{3}{*}{ Differentiated-1 } & $\begin{array}{c}\text { no } \\
\text { fertilizers } \\
\text { (control) }\end{array}$ & $18,606.0$ & $10,248.7$ & $8,357.3$ & 82.9 \\
\hline & & $\mathrm{N}_{82.5} \mathrm{P}_{60}$ & $36,860.7$ & $13,494.3$ & $23,366.3$ & 172.6 \\
\hline & & $\mathrm{N}_{120} \mathrm{P}_{60}$ & $42,397.7$ & $14,794.0$ & $27,602.3$ & 185.0 \\
\hline \multirow[t]{3}{*}{5} & \multirow[t]{3}{*}{ Differentiated-2 } & $\begin{array}{c}\text { no } \\
\text { fertilizers } \\
\text { (control) } \\
\end{array}$ & $15,697.3$ & $10,224.7$ & $5,472.7$ & 55.6 \\
\hline & & $\mathrm{N}_{82.5} \mathrm{P}_{60}$ & $32,083.3$ & $13,537.0$ & $18,546.3$ & 136.2 \\
\hline & & $\mathrm{N}_{120} \mathrm{P}_{60}$ & $37,488.3$ & $14,750.0$ & $22,738.3$ & 152.7 \\
\hline
\end{tabular}




\section{Efficiency of minimized systems of basic tillage and sowing in previously unprepared soil in grain-row crop rotation}

Mastering of soil-protective resource-saving and zero systems of basic tillage with wide use of high-performance tools of the plow, chisel, disk type and drills that combine tillage with sowing have been conducted at Askanian Research Station of the Institute of Irrigated Agriculture of NAAS since 2008.

With this purpose, the efficiency of long-term use of systems was studied in the stationary irrigated field in short crop rotation with soybean, winter wheat, corn and barley: differentiated tillage, where during the rotation plowing on the depth of $28-30 \mathrm{~cm}$ under row crops was changed by the shallow $(12-14 \mathrm{~cm})$ disk loosening under winter cereals; single-depth shallow $(12-14 \mathrm{~cm})$ disking for all the crops of the rotation; different-depth chisel $(23-25-28-30 \mathrm{~cm})$ loosening during the crop rotation; and the constant use of zero tillage, which combines cultivation with the sowing of the crop in one aggregate without previous tillage.

To evaluate the efficiency of the application of minimized and zero systems of basic tillage, the studies of agro-physical properties, water and nutrient regime of the soil and productivity of the crops were conducted.

Determination of the bulk density of the soil before the experiment setting (2008) showed that it was the highest in the soil layer of $0-40 \mathrm{~cm}$ at the use of sowing crops into the previously untreated soil and was $1.42 \mathrm{~g} / \mathrm{cm}^{3}$.

A very significant compaction was also observed under the use of shallow plowless tillage on the depth of $12-14 \mathrm{~cm}-1.41 \mathrm{~g} / \mathrm{cm}^{3}$. At these tillage systems, the most compacted soil layer was $10-20 \mathrm{~cm}$ and was respectively $1.44 \mathrm{~g} / \mathrm{cm}^{3}$ and $1.46 \mathrm{~g} / \mathrm{cm}^{3}$.

In general, changes in agro physical conditions, water and nutrient regime under the different systems of basic tillage and fertilizer doses had a significant impact on the crop production and the crop rotation productivity (Table 7).

Table 7

Crop yields and crop rotation productivity under different tillage systems and fertilizer doses, average for 2009-2018

\begin{tabular}{|c|c|c|c|c|c|}
\hline \multirow[b]{2}{*}{ Basic tillage system } & \multicolumn{4}{|c|}{ Crop yields of the crop rotation, $t / h a$} & \multirow[b]{2}{*}{$\begin{array}{l}\text { Productivity of } \\
\text { crop rotation, } \\
\text { (the grain } \\
\text { units) }\end{array}$} \\
\hline & $\begin{array}{c}\text { winter } \\
\text { wheat } \\
+ \\
\text { mustard } \\
\text { for } \\
\text { green } \\
\text { manure } \\
\end{array}$ & $\begin{array}{l}\text { grain } \\
\text { corn }\end{array}$ & $\begin{array}{c}\text { winter } \\
\text { barley }+ \\
\text { mustard } \\
\text { for } \\
\text { green } \\
\text { manure }\end{array}$ & soybean & \\
\hline \multicolumn{6}{|c|}{ fertilizers dose of $\mathrm{N}_{60} \mathrm{P}_{40}$} \\
\hline Differentiated & 6.19 & 9.32 & 5.37 & 3.34 & 6.59 \\
\hline Plowless shallow & 5.85 & 7.94 & 5.32 & 3.28 & 6.12 \\
\hline $\begin{array}{c}\text { Different-depth } \\
\text { plowless }\end{array}$ & 6.01 & 8.69 & 5.42 & 3.35 & 6.40 \\
\hline Zero & 5.28 & 6.56 & 4.52 & 2.90 & 5.28 \\
\hline
\end{tabular}




\begin{tabular}{|c|c|c|c|c|c|}
\hline \multicolumn{7}{|c|}{ fertilizers dose of $\mathbf{N}_{\mathbf{9 7 . 5}} \mathbf{P}_{\mathbf{4 0}}$} \\
\hline Differentiated & 6.68 & 10.34 & 5.84 & 3.73 & 7.25 \\
\hline Plowless shallow & 6.36 & 9.30 & 5.86 & 3.76 & 6.92 \\
\hline $\begin{array}{c}\text { Different-depth } \\
\text { plowless }\end{array}$ & 6.40 & 10.26 & 5.94 & 3.85 & 7.23 \\
\hline Zero & 5.67 & 7.56 & 4.88 & 3.28 & 5.88 \\
\hline \multicolumn{7}{|c|}{ fertilizers dose of $\mathbf{N}_{\mathbf{1 3 5}} \mathbf{P}_{\mathbf{4 0}}$} \\
\hline Differentiated & 6.92 & 11.08 & 6.30 & 3.87 & 7.66 \\
\hline Plowless shallow & 6.78 & 9.95 & 6.32 & 3.82 & 7.33 \\
\hline $\begin{array}{c}\text { Different-depth } \\
\text { plowless }\end{array}$ & 6.83 & 11.02 & 6.34 & 3.99 & 7.69 \\
\hline Zero & 6.14 & 8.09 & 5.28 & 3.27 & 6.22 \\
\hline
\end{tabular}

\section{CONCLUSIONS}

The basic tillage in the arid conditions of Southern moderately dry, Drysteppe and very Dry soil-ecological subzones of the Steppe zone should ensure, first of all, rational use of land, water and material resources, high crop yields, productivity of crop rotations, preservation of soil fertility and improvement of the ameliorative conditions of irrigated lands.

Prolonged use of differentiated systems of basic tillage in crop rotation at irrigation has ensured, on the background of application of different doses of mineral fertilizers, the formation of the highest level of productivity. Not significant decrease was observed in the variants of different-depth chisel and single-depth shallow disk loosening, mainly due to the yield of corn grain.

Sowing in untreated soil over 10 years of the research has led to a significant decrease in the crop yields and the crop rotation productivity in general.

\section{SUMMARY}

The article reflects the results of the study on the effect of basic tillage and fertilization on the productivity of the irrigated crop rotations.

The aim of the study was the determination of the effect of basic tillage and fertilization on the productivity of the irrigated crop rotations of the South of Ukraine. The task of the study was to determine the impact of the studied factors on the yielding indexes, and energy efficiency of the crops cultivation technologies at irrigation.

Field experiments were carried out with accordance to the methodology of research work. Cultivation technologies of the crops in the irrigated crop rotations were generally accepted for the conditions of the South of Ukraine.

The regulations of the impact of basic tillage on the agro physical properties, nutritive regime of the soil, which contributed to the creation of 
favorable conditions for growth, development and productivity of the studied crops, were established. It was proved that application of the plowless basic tillage provides the increase of winter wheat grain yield within $0.1-0.6 \mathrm{t} / \mathrm{ha}$. At the same time, row crops react negatively on the plowless tillage that was evident by the decrease in the yield of soybean by $0.4-0.5$; corn - by 1.0-1.4 t/ha. The increase of fertilization to $\mathrm{N}_{97,5} \mathrm{P}_{60} \mathrm{~kg}$ of the active substances per 1 ha of the cropland provided the increase in the yields of all the crops within the crop rotation with the maximum productivity indexes $124.4 \mathrm{GJ} / \mathrm{ha}$ on the variants with plowing different-depth and differentiated systems of tillage in the crop rotation. The ANOVA proved that grain yields of winter barley and corn were mostly affected by nitrogen fertilizers, by 74.9 and $54.9 \%$ respectively from the whole share of the weight of these crop productivity formation, and different schemes of basic tillage had such strength of the impact: on barley $-21.1 \%$; on corn $-36.1 \%$.

\section{REFERENCES}

1. Класифікація грунтів України. К.: Аграрна наука, 2005. 299 с.

2. Система ведення сільського господарства Херсонської області. Херсон: «Айлант», 2004. 164 с.

3. Балюк С. А., Ромащенко М. І., Трускавецький Р. С. Меліорація грунтів систематика, перспективи, інновації. Херсон, 2015. 667 с.

4. Коваленко П. І. Інтегроване управління водними і земельними ресурсами на меліорованих територіях. Київ: Аграрна наука, 2009. 783 с.

5. Ромащенко М. І., Вожегова Р. А., Шатковський А. П. Наукові засади розвитку аграрного сектора економіки південного регіону. Херсон: Олді- плюс, 2017. 437 с.

6. Бурзі К. Е., Красутська Н. В., Синицина Н. П., Сафонова О. П. Сольовий режим грунтів Інгулецького зрошуваного масиву. Зрошуване землеробство. 1971. Вин. 12. С. 63-67.

7. Балюк С. А., Ромащенко М. І., Сташук В. А. Наукові основи охорони та раціонального використання зрошуваних земель України. Київ: Аграрна наука, 2009. 620 с.

8. Вожегова Р. А., Сташук В. А., Заришняк А. С. Системи землеробства на зрошуваних землях. Київ: Аграрна наука, 2014. 359 с.

9. Малярчук М. П., Нижеголенко В. М., Резніченко Н. Д., Воронюк Л. А. Системи землеробства в умовах південного посушливого та сухого степу. Збірник матеріалів Міжнародної науково-практичної конференції «Наукові засади ефективного ведення степового землеробства в умовах змін клімату» 28-29 травня 2015 р. Херсон: Грінь Д.С., 2015. С. 141-145. 
10. Малярчук М. П., Вожегова Р. А., Марковська О. С. Формування систем основного обробітку грунту в агробіоценозах на меліорованих землях південної посушливої та сухо степової грунтовоекологічних підзон України. Навчальний посібник. Херсон: Айлант, 2012. $180 \mathrm{c}$.

11. Малярчук М. П., Писаренко П. В., Мишукова Л. С., Малярчук А. С. Котельников Д. І., Нижеголенко В. М. Ефективність мінімізованих способів основного обробітку і сівби в попередньонеоброблений грунт при вирощуванні кукурудзи на зрошуваних землях. Зрошуване землеробство: збірник наукових праць. Херсон: Айлант, 2013. Вип. 59. С. 36-38.

12. Малярчук М. П. Система обробітку грунту. Наукові основи охорони та раціонального використання зрошуваних земель України. Київ: Аграрна наука, 2009. С. 299-313.

13. Малярчук М. П. Формування систем обробітку грунту в сівозмінах на меліорованих землях Південного Степу України. Посібник Українського хлібороба. 2014.

\section{Information about the author:} Biliaieva I. M., Doctor of Agricultural Sciences, Senior Researcher, Institute of Irrigated Agriculture of the National Academy of Agrarian Sciences of Ukraine Kherson, Naddniprianske, 73483, Ukraine 
DOI https://doi.org/10.36059/978-966-397-154-4/46-66

\section{GLOBAL CHANGE IN CLIMATE AND ITS EFFECT ON THE FORMATION OF CROPS IN SOUTHERN STEPPE OF UKRAINE}

\section{Holoborodko S. P.}

\section{INTRODUCTION}

The study of the Intergovernmental Panel on Climate Change (IPCC) under the UNO, which was proved by the national academies of the countries of the Group of Seven, determined that in comparison to the year of the start of industrial revolution (1850) the average temperature of the Earth increased $0.7^{\circ} \mathrm{C}$ and it is within $+15^{\circ} \mathrm{C}$ that supports the existence of sustainable biogeocenosis on the planet ${ }^{1}$. It was determined by the assessment of the climatic models of IPCC that in XXI century the average temperature of the Earth can possibly rise up by $1.1-6.4^{\circ} \mathrm{C}$, which will lead to the warming and elevation of the World Ocean level through a thousand years. The increase of the global temperature on the Earth will lead to the change in amounts and distribution of precipitation and more frequent occurrence of natural disasters such as flooding, drought, hurricane, etc., that will cause the decrease or complete destruction of the crops and to the extinction of many biological species of plants and animals. Herewith, global change in climate will be favorable for the increase of frequency and scale of the above-mentioned phenomena ${ }^{2}$.

The reason of the global change in climate on the Earth is studied by many countries at the moment; however, in most cases they are fragmental and often are in a contrary to each other but are also the same in many things. The paleontological studies of IPCC in the change of the water level in the World Ocean for the last 0.5 million years and in the determination of the Oxygen isotope concentration in the sea water $\left({ }^{18} \mathrm{O}\right)$ and Carbon dioxide $\left(\mathrm{CO}_{2}\right)$ in the Antarctic ice revealed the presence of long-term climatic cycles, which in the Quarternary period took the form of periodical frozen and

1 Исследования межгосударственной группы экспертов при ООН. [Электронный pecypc]. Начало повышения температуры на планете. Режим доступа: Internet resources: http://ru.wikipedia.org/wiki/.

2 Влияние парниковых газов на глобальное изменение климата. [Электронный pecypc]. Причины нагревания поверхности Земли. Режим доступа: Internet resources: http://www.referatik.com.ua/subject/97/41350/?page=2. 
coincide with inter-ice temperature maximums. The main reasons of the above-mentioned changes in climate in time are still studied insufficiently, however, there are several ones with accordance to present scientific models: change of the Earth orbit around the Sun (the cycles of Milankovich), volcanic dust, change of the sun activity and greenhouse effect ${ }^{3}$. For the first time greenhouse effect has been defined by Joseph Fourier in 1824, and it was quantitatively determined by Svante Arrhenius in 1896. The latter is determined by considerable emissions of Carbon dioxide $\left(\mathrm{CO}_{2}\right)$, methane $\left(\mathrm{CH}_{4}\right)$ and Nitrous oxide $\left(\mathrm{N}_{2} \mathrm{O}\right)$ in the atmosphere, at the absorption of which infrared emanation takes place that causes heating both of the atmosphere and the surface of the planet. The main greenhouse gases on the Earth are: water vapor (36-70 Carbon dioxide $\left(\mathrm{CO}_{2}\right)$ (9-26\%), methane $\left(\mathrm{CH}_{4}\right)$ (4-9\%) and tropospheric ozone $\left(\mathrm{O}_{3}\right)$ (3-7\%). All the mentioned gases, including Fluor and Chloral hydrates, are called greenhouse in general. In comparison to the beginning of the industrial revolution in the middle of XVIII century (1850 p.), since the beginning of which more than 150 years have passed, concentration of $\mathrm{CO}_{2}$ in the atmosphere of the Earth increased by $31 \%$, and $\mathrm{CH}_{4}$ by $149 \%{ }^{4}$. At the same time, all the pollution sources of the atmospheric space (coal electricity stations, the tubes of metallurgic plants, car outlets, etc.) emit up to 22 milliard tons of greenhouse gases each year ${ }^{5}$. Besides, at the application of fertilizers, burning of coal, natural gas and oil, changes of agrolandscapes, firstly, disforesting and plowing of natural meadows, up to 250 million tons of $\left(\mathrm{CH}_{4}\right)$ emit to the atmosphere each year. This is caused by the fact that the surface of the land without plants, comparatively to the plant-settled one, is heated stronger that causes the increase of water vapor condensation of precipitation and leads to the decrease of their amounts, the occurrence of drought.

The effect of greenhouse gases, first of all, Carbon dioxide of his stable isotopes $\left({ }^{12} \mathrm{C}\right.$ and $\left.{ }^{13} \mathrm{C}\right)$ and a radioactive one $\left({ }^{14} \mathrm{C}\right)$ with a half-life of 5730 years, on the global change in climate consists in that they absorb and transfer to all the directions the part of infrared radiation, coming to the surface of the Earth. This is the reason of the increase of their concentration in the atmosphere, which is absorbed by greenhouse gases, in consequence

\footnotetext{
${ }^{3}$ Гидрологический словарь. Под ред. В.М. Котлякова. Л.: Гидрометиздат, 1984. 527 с.

${ }^{4}$ Концентрация углекислого газа в атмосфере. [Электронный ресурс]. Изменение структуры агроландшафтов. Режим доступа: Internet resources: http://enrin.grida.no/ htmls/tadjik/ntalgraphics/rus/html/climate.htm.

5 Источники загрязнения атмосферы. [Электронный ресурс]. Ежегодные выбросы парниковых газов. Режим доступа: Internet resources: http://www.ukragroconsult.com/ contentview/46301/61/.
} 
of the heating of the lower layers of troposphere and the surface of the Earth happens ${ }^{6}$.

The history of the Carbon cycle on the Earth is currently studied sufficiently by the isotopes of Carbon and its relative distribution in sedimentary rocks. It stems from the data that Carbon cycle had long periodical changes that correlated with the ages of soil formation. At the time of tectonic moves activation, the sediments of Carbonate rocks strengthened and its isotopic content became heavier that corresponded to the increase of Carbon drift from the core source, which mainly contains enriched Oxygen. Therefore it is believed that the main measurements of the Carbon cycle were through the strengthening of the erosion of the continents as a result of mountains formation.

\section{State of the problem study}

Nowadays, the history of the change of Carbon dioxide $\left(\mathrm{CO}_{2}\right)$ and methane $\left(\mathrm{CH}_{4}\right)$ content in the atmosphere in the Quarternary period is relatively well studied from the surface glaciers of Greenland and Antarctica. The Quarternary period is distinguished from other geological periods by the cyclic epochs of ice and inter-ice ages when the changes in climate distinctly correlated with the changes of the Carbon cycle. At the same time, even in this most studied period there is no sufficient clarity about the reasons of cyclic changes on the Earth and the connection of geochemical changes with climatic ones. It is determined that the Quartenary period was characterized with four frozen, which with the period up to 100 thousand years took place one by one. Herewith, atmospheric content of $\mathrm{CO}_{2}$ and $\mathrm{CH}_{4}$ changed with the accordance to the variations of temperature that resulted in the determination of the following statements:

1. All the Quartenary frozen took place with the period of nearly 100 thousand years.

2. Each ice age was accompanied by the decrease of the concentration of Carbon dioxide $\left(\mathrm{CO}_{2}\right)$ and methane $\left(\mathrm{CH}_{4}\right)$ in the atmosphere.

3. Inter-ice ages began with the sharp, momentarily in the geological scale, increase of the concentration of $\mathrm{CO}_{2}$ and $\mathrm{CH}_{4}$.

4. At the time of inter-ice ages there was a gradient of the methane $\left(\mathrm{CH}_{4}\right)$ concentration between Northern and Southern hemispheres that is proved by the content of the air got form the glaciers of Greenland that were significantly higher than Antarctic ones. During the ice ages the

\footnotetext{
${ }^{6}$ Поглощение инфракрасной радиации. [Електронний ресурс]. Причины увеличения концентрации парникових газов. Режим доступу: www.un.org/ru/documents/decl_conv/ conventions/agenda21_ch12b.shtml.
} 
concentration of methane $\left(\mathrm{CH}_{4}\right)$ in the both hemispheres decreased and gradually evened.

5. During the ice ages the content of light Carbon isotope decreased.

The development of frozen led to the decrease of the biomass of surface biosphere, and as all plants selectively absorbed the light Carbon isotope from the atmosphere, at the coming of ice ages all the light Carbon emitted to the atmosphere, and through it to the Ocean. Based on the modern biosphere, its average isotopic content and analogical data of the Ocean, and knowing the changes of isotopic content from the remnants of sea organisms at the time of ice ages it was calculated the change of the surface biomass of the previous ice ages. Such estimations were conducted and reached 400 tons in comparison to the modern mass. In this way, the change of isotopic content of Carbon in the nature of the Earth were defined.

All the Quartenary frozen were developed in Northern hemisphere where there are greater continental landscapes. There were mostly oceans in Southern hemisphere and there were almost no big marshes - the sources of methane, because marshes are concentrated only in Northern boreal belts ${ }^{7}$.

The development of frozen led to the decrease of the size of Northern marshes - one of the main sources of methane $\left(\mathrm{CH}_{4}\right)$ and at the same time absorbents of Carbon dioxidei $\left(\mathrm{CO}_{2}\right)$. Therefore, during the inter-ice ages, when the area of marshes was the maximum in Northern hemisphere, the concentration of methane in the atmosphere was always higher that is explained by the presence of methane concentration gradient between the hemispheres in the inter-ice ages ${ }^{8}$.

Anthropogenic activity of humankind made new inputs in the cycle of Carbon. With the beginning of industrial era, people began to burn the mineral fuels: coal, oil and gas, which were stored for the million years of the Earth existence. Human activity caused significant changes in land-use: disforesting, plowing of the herbage of natural grasslands, marshes drainage, flooding of the previously dry lands, etc. Because the history of the planet consists of grandiose events, talking about the change of the Carbon cycle by the man we have to adjust the scales and duration of these effects with the events of the past. Some of these facts are found out but the reason-cause connections still have no response. A number of researchers state that the change in climate on the Earth occurs within the boards of its own natural variability and is caused by the repetitive processes that take place in the

\footnotetext{
${ }_{8}^{7}$ Мачерет Ю.П. Радиозондирование ледников. М.: Науч. мир, 2006. 392 с.

8 Причины увеличения метана в атмосфере. [Электронный ресурс]. Наличие градиента концентрации метана в межледниковые периоды. Режим доступа: Internet resources: http://www/lib/ua-ru/net/inode/p-2/14290.html.
} 
system Earth - the Sun - Space. By the existent in climatology classification of the cycles of climate there are four groups of them: super long - 150300 million years, longi - 10-50 million years, short - hundreds and thousands years, and ultra-short connected with the activity of the Sun and are measured within $2400,200,90$, and 11 years ${ }^{9}$. The existing models of global climatic change testify that the determined rhythms of the Sun at the time are determinative in the increase of the temperature on the Earth and in the World Ocean. At the same time, global increase of the average temperature of the Earth and the World Ocean does not mean warming of climate everywhere and in any time. According to one of the IPCC models, global warming on the Earth will lead to partial weakening or, perhaps, will completely stop the Gulf Stream that will affect on considerable decrease of the average temperature in Europe. IPCC also related to the negative changes in climate of Europe in 2001 in Shanghai the increase of temperatures and drought periods in the South, shortening of snow cover and recession of mountain glaciers, increase of strong floods and high waters on the rivers; the increase in Central and Eastern Europe of summer precipitation, forest and peat fire occurrence, diminishing of forest productivity, increase in soil erosion in Northern Europe. In Arctic catastrophic decrease of the area of full ice cover, diminishing of the areas of sea ice, increased erosion of the banks ${ }^{10}$.

In the historical aspect of the Earth, slowing down of the Gulf Stream is connected with ice ages - relatively long stages in the geological history of the planet, during which on the arena of general relative cooling of climate there were many times during which the interchange of sharp cooling periods, accompanied with the intensive ice-covering, and relative warming during which continental ices diminished in their sizes that is observed at the moment in Arctic and Antarctica. The coming of small ice age was connected with slowing down of the Gulf Stream, which had begun after 1300. Beginning from 1300, Western Europe, as it was determined, survived an ecological catastrophe. Intensive rainfall in the summer and severe winters resulted in the ruin of crops for several consequent years, because of this, orchards and vineyards were destroyed by frost in England, Scotland, Northern France and Germany. The consequence of the first stage of the small ice age in the first half of XIV century was starvation in the countries of Europe, which partially finished just after 1370. Relative warming of the

\footnotetext{
${ }^{9}$ Природная изменчивость процесса Солнце-Земля. [Электронный ресурс]. Циклы изменения климата. Режим доступа: Internet resources: http://www.ukrindustrial.com./news/ index.php.?newsid=219087.

${ }_{10}$ Уменьшение площади ледников Арктики. [Электронный ресурс]. Усиление эрозии морских берегов. Режим доступа: Internet resources: http://www.zn.ua/3000/3320/63430/.
} 
climate in the countries of Western and Central Europe was just in the second stage of the small ice age in the beginning and middle of XVI century, when the maximum activity of the Sun partially extinguished the negative process of the Gulf Stream slowing down. The coldest period of the small ice age was its third stage, which lasted during the end of XVI beginning of XIX century, when the decreased activity of the Gulf Stream coincided in time with the lowest level of the sun activity. In the countries of Southern Europe in this period almost every year severe and long winters repeated, during which in 1621-1629 the Bosporus was frozen, and in 1709 the Adriatic Sea was frozen near the banks ${ }^{11}$.

The coldest year was 1665, when in the winter of 1664-1665 birds were frozen during the flight in the air in Germany and France. High mortality was observed in all the European countries, the population of Scotland and Estonia decreased by $30 \%$ and of Finland - by 50\%. The anomalous wave of cooling in the countries of Europe also took place in 1740-1784, when stable cold weather with snow and ice cover was observed in Germany, Swiss and France with the air temperature $-7-10^{\circ} \mathrm{C}$ that lasted to the end of April ${ }^{12}$.

Therefore, the admirers of the theory of small ice age state that current warming on the Earth is the natural escape from the ice age of XIVXIX centuries that will lead to the renovation of the temperatures of the Atlantic optimum.

Together with the cold geological period, there was a manifestation of sudden warming that was nearly 55-65 million years ago, and was accompanied by significant change of the atmosphere and extinction of a number of plants and animals ${ }^{13}$. With accordance to paleoclimatic investigations, the temperature on all the continents of the Earth at the time of thermal maximum reached $20^{\circ} \mathrm{C}$ that is by $1,5^{\circ} \mathrm{C}$ more than the current value, and in the seas of Arctic warming happened in larger dimensions than nowadays. Duration of the late-paleocenic thermal maximum lasted for more than 200 thousand years, and it is impossible to reliably determine the reason of this geological event till now. One of the models for this phenomenon could be dramatic increase of Carbon dioxide $\left(\mathrm{CO}_{2}\right)$ in the atmosphere that reached $2-3 \%$ (the current is $0.038 \%$ ) and, especially, methane $\left(\mathrm{CH}_{4}\right)$, the

${ }^{11}$ Фазы ледниковых периодов. [Электронный ресурс]. Продолжительность зимних периодов в Европе. Режим доступа: Internet resources: http://www.podrobnosti.ua.health/ 2008.08.22/548886.html.

12 Аномальне похолодання в Европе. [Электронный ресурс]. величение продолжительности зимного периода. Режим доступа: Internet resources: http://www.grida.no/climate/ipec_tor/vol14/russian/083.htm

13 Палеонтологические исследования. [Электронный ресурс]. Причины вымерания отдельных видов растений и животных. Режим доступа: Internet resources: http://imm.org.ua/se/news/index.php?action=show\&nid=4163 
increase of the concentration of which in the atmosphere dominated in the early history of the Earth and could cause global warming.

During the largest thermal maximum that took place on the Earth more than 65 million years ago, there took place a global change in the biosphere, which resulted in the extinction of many species of mammals, and they were replaced by the species of modern type. Duration of natural Carbon abnormality and its complete disappearance lasted for 150 thousand years, after which the Earth returned to its normal state.

The analysis of the extreme situation, which occurred in nature and agricultural production of different countries of the world this time, certifies about the fact that the reason of the change in climate of the Earth and its catastrophic consequence is still insufficiently studied because the first reason of the phenomenon is not clarified.

One of the reasons that caused the change of geochemical cycle in the nature of greenhouse gases, first of all, Carbon dioxide $\left(\mathrm{CO}_{2}\right)$ and methane $\left(\mathrm{CH}_{4}\right)$, is the disturbance of the regular process of continuous energy exchange of the space system the Earth-the Sun, by the human activity connected with the mining of oil from interior of the Earth ${ }^{14}$. The world oil consumption at the beginning of XXI century (2004-2005) reached 3031 milliard barrels per year, and the opened new storages during these years do not overcome 8 milliard barrels and exceeding of the mining over the consumption was only 2 million barrels a day. That is why because in XXI century the search for the replacement energy sources for oil, but as the search for the alternative energy sources is difficult, long and expensive, the oil mining from the interior of the Earth is going on all the time. By the data of scientific works of the National Academy of Sciences of Ukraine, the oil formation on the planet Earth has inorganic origin and gets through consequent geocosmoplasmochemical processes performing donor-acceptor function between the movements of electrons from the surface of the Earth to its core. Based on the physic-chemical properties of Carbon, $87 \%$ of which is in the composition of oil, the process of core synthesis on the surface of the planet core is provided, and therefore geocosmoplasmochemical process of new substance. Therefore, in the regions of intensive oil mining the sustainably existent link is destroyed resulting in the increase of electric conductivity with ionosphere that causes the increase of greenhouse effect and the acceleration of the climate change on the Earth. The latter causes storms, typhoons, tornadoes, intensive melting of the icecover firstly of Arctic and Antarctic. Therefore, the increase of the average

\footnotetext{
${ }^{14}$ Bentley R. W. Global oil and gas depletion: an overview. Energy Pochy. 2002. № 30. P. 189-205.
} 
temperature of the Earth during the last 50 years was found to be twice bigger than at the last 100 years. Herewith, it is warming two times faster in Arctic than in other climatic zones because of the zone of spreading the ice just in the last 30 years by every decade decreased by $2.7 \%$. If greenhouse gases in XXI century will emit to the atmosphere in the same amount as now then the average temperature on the planet will reach $2-4^{\circ} \mathrm{C}$ that might cause the extinction of $20-30 \%$ species of existent animals and plants in different biocenosis. At the same time, the level of water in the World Ocean is rising, which became $17 \mathrm{~cm}$ higher during the last $\mathrm{XX}$ ccentury or higher than during the previous 2000 years.

At the same time, Danish ecologist Bjorn Lomborg considers that the process of global warming on the Earth is connected not only with anthropogenic activity but with the internal processes that take place inside the planet and are connected with the continents movement. At the moment, there were discovered on the bottom of oceans thousands of hydrothermal sources "black smokers" with the height of up to 120 meters and up to 200 meters in diameter, which are continuously emitting tons of greenhouse gases in the atmosphere, such as Carbon dioxide $\left(\mathrm{CO}_{2}\right)$, methane $\left(\mathrm{CH}_{4}\right)$ and Hydrogen sulphide $\left(\mathrm{H}_{2} \mathrm{~S}\right)$. At the same time, only one such a hydrothermal source emits Carbon dioxide and methane 30 times more than all the industrial factories of the World. The emitted gases are not kept in pure sea water, and come into the natural circulation. Hence the bottom of oceans has thousands of the mentioned hydrothermal sources, even the limitation of greenhouse gas emission with accordance to Kyoto agreement or even stopping all the industry will not reduce the process of global warming on the planet ${ }^{15}$.

\section{Results of the study}

The problem of agricultural production in connection with the intensive tempo of global and local change in climate at the moment is sharpened that is manifested through the increase of average annual air temperature, intensive natural disasters, including drought, occupying up to $50-70 \%$ of the territory of Ukraine. The analysis of long-term observations on the weather conditions conducted by Kherson meteorological station in Southern part of the Steppe zone allowed determination and absolute value of hydrothermal indexes in different by humidification years. On average for 65 years of

15 Киотский протокол. [Электронный ресурс]. Ограничение выбросов парникових газов на планете. Режим доступа: Internet resources: http: // echo. msk.ru/news/511753echo.html. 
observations (1945-2010) evapotranspiration was $722.0 \mathrm{~m}$, and moisture deficit did not surpass $487.4 \mathrm{~mm}$ (Fig. 1).

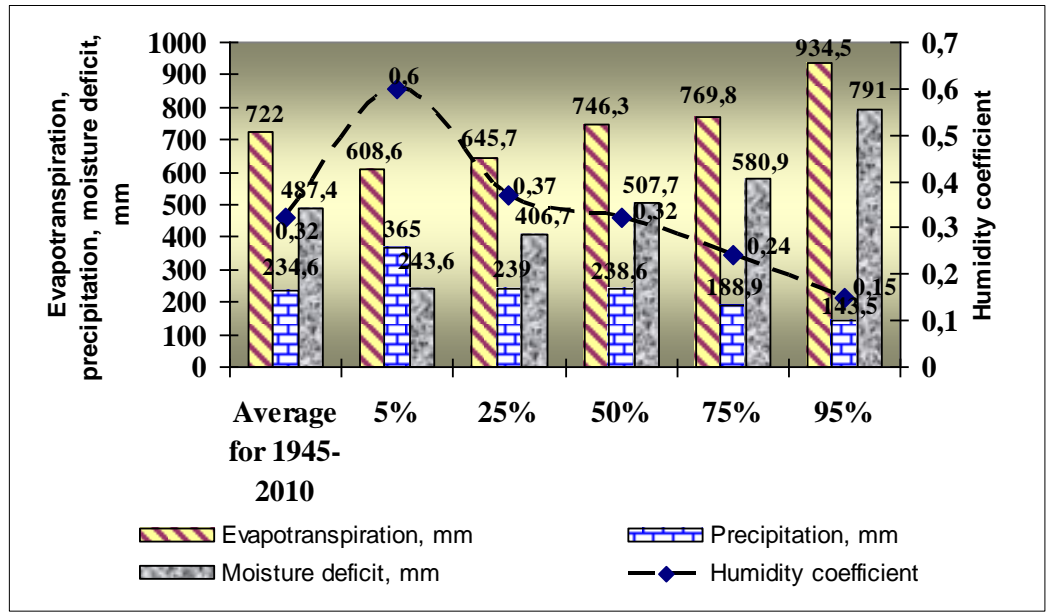

Fig. 1. Hydrothermal indexes of vegetation period of crops in different years by the precipitation supply (by the data of Kherson meteorological station)

In the humid (5\%) years evapotranspiration did not overscore $608.6 \mathrm{~mm}$, respectively, moisture deficit decreased to $243.6 \mathrm{~mm}$. In the moderately humid $(25 \%)$ and moderate $(50 \%)$ years evapotranspiration increases to 645.7-746.3 mm, and moisture deficit increases to 406.7-507.7 $\mathrm{mm}$. In the moderately dry (75\%) and dry (95\%) years evapotranspiration increases to 769.8-934.5 mm, and moisture deficit - to 580.9-791.0 $\mathrm{mm}$.

Humidity coefficient calculated by the indexes of Kherson and Askanian meteorological stations during the vegetation period of crops coincide in general. On average for 1945-2010 humidity coefficient in April was 0.390.43; May - 0.39; June - 0.37; July - 0.26; August - 0.19-0.22 and September $-0.29-0.37$. The highest indexes of humidity coefficient were revealed in April - 0.39-0.43 and September - 0.29-0.37, and the lowest ones were in July -0.26 and August 0.19-0.22 (Fig. 2). 


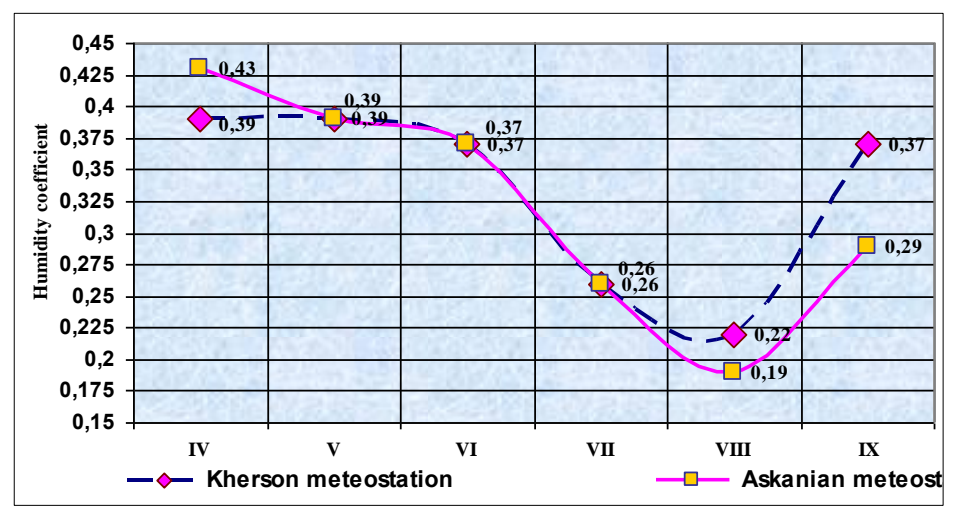

Fig. 2. Humidity coefficient during the vegetation period of perennial herbs (April-September) (by the data of Kherson and Askanian meteorological stations, average for 1945-2010)

The decrease of humidity coefficient during the last years takes place together with significant increase in average month temperature and decrease of relative air humidity. The increase of average month temperature testifies about significant change of heat, air and radiation regimes in the sub-zone of Southern Steppe during the vegetation period of dry (95\%) 2017 year (Fig. 3).

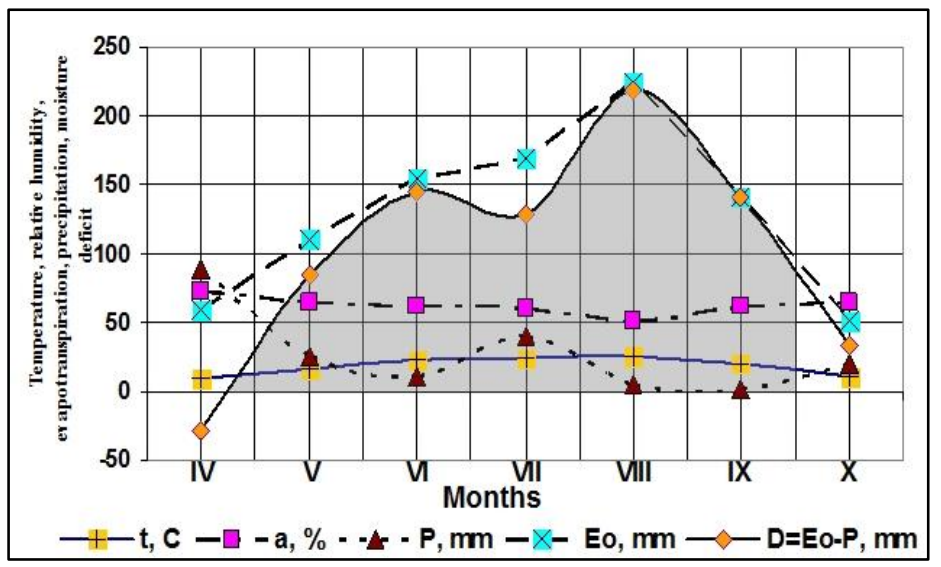

Fig. 3. Hydrothermal indexes of the vegetation period of crops in dry (95\%) 2017 year (the zone colored grey is the area equaling the moisture deficit of crops) 
On the whole, moisture deficit during the vegetation period of crops was $690.0 \mathrm{~mm}$ and, compared to the perennial indexes, it was higher by $81.2 \mathrm{~mm}$ or $16.0 \%$. At the same time, it reached in May $84.9 \mathrm{~mm}$; in June - 144.8; in July - 128.9; in August - 219.2 and in September - $140.8 \mathrm{~mm}$. Humidity coefficient in dry (95\%) 2017 year on average for the vegetation period was 0.20 including: in April - 1.48; in May - 0.23; in June - 0.07; in July - 0.24; in August - 0.02 and in September - 0.01 (Fig. 4).

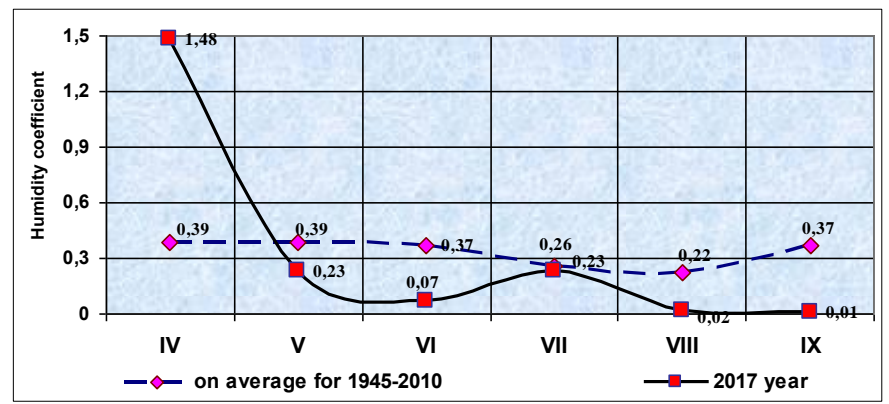

\section{Fig. 4. Humidity coefficient during the vegetation period of crops in dry $(95 \%) 2017$ year and on average for 1945-2010 (by the data of Kherson meteorological station)}

According to N.N. Ivanov ${ }^{16}$ the indexes presented testify about the fact that the territory of Southern part of the Steppe zone by the humidity coefficient during May-September in dry (95\%) 2017 year belonged to semi-arid and arid zone. On average for 65 years of observation (1945-2010) precipitation amount in winter (XII-II months) did not over score $93.0 \mathrm{~mm}$, respectively, in spring (III-V) - 93.7; summer (VI-VIII) - 126.3 and autumn (IX-XI months) $102.7 \mathrm{~mm}$. During the vegetation period (April-September) precipitation amount on average for 1945-2010 was $232.7 \mathrm{~mm}$, respectively, in $2011-185.5 \mathrm{~mm}$; 2012 - 186.6; 2013 - 154.2; 2014 - 218.5; 2015 - 315.2; 2016 - 277.7 and in $2017-169.1 \mathrm{~mm}$.

Precipitation amount, which has fallen during 2011-2017, in moderately dry (75\%) and dry (95\%) years testifies that in comparison to the average long-term one in 1945-2010 it was significantly lower and did not exceed 47.2-63.6 mm. If on average for 1945-2010 precipitation amount was $232.7 \mathrm{~mm}$, then in 2011 its amount was $185.5 \mathrm{~mm}$, respectively, in 2012 - 186.6; 2013 - 154.2; 2014 218.5; 2015 - 315.3; 2016 - 277.7 and in 2017 - $169.1 \mathrm{~mm}$ (Fig. 5).

16 Иванов Н. Н. Показатель биологической эффективности климата. Известия Всесоюзного географического общества. 1962. Т. 94. Вып. 1. С. 65-70. 


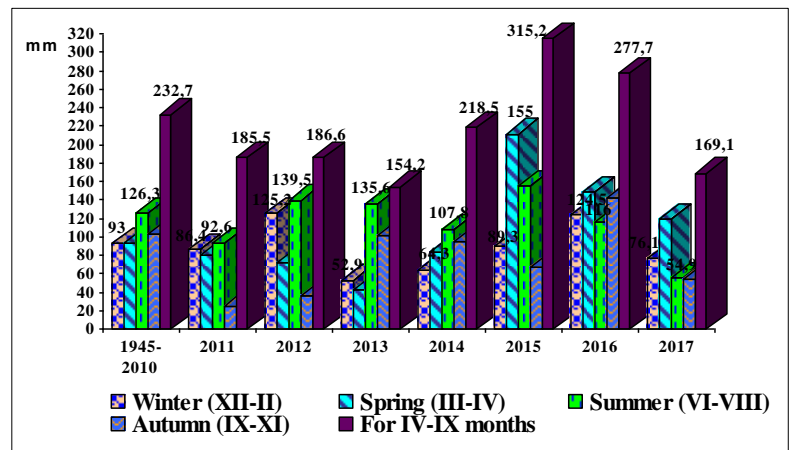

Fig. 5. Precipitation amount in different years during the vegetation period of crops (April-September) and by the seasons in the sub-zone of Southern Steppe Of Ukraine (by the data of Kherson meteorological station)

The decrease of precipitation in the spring period in dry (95\%) 2012 year, in comparison to 1945-2010, by $22.6 \mathrm{~mm}(24.1 \%)$ and in the autumn - by $66.4 \mathrm{~mm}$ $(64.6 \%)$ at the simultaneous increase of the air temperature in the mentioned periods of the year by $2.7^{\circ} \mathrm{C}$ and $2,8^{\circ} \mathrm{C}$ in general for the vegetation period (IV-IX months) led to the increase of evapotranspiration by $217.5 \mathrm{~mm}(29.9 \%)$ and moisture by $263.6 \mathrm{~mm}$, or by $53.4 \%$.

Evapotranspiration and moisture deficit during 2011-2017 significantly changed and depended on the average month temperature and relative air humidity and precipitation amount (Fig. 6).

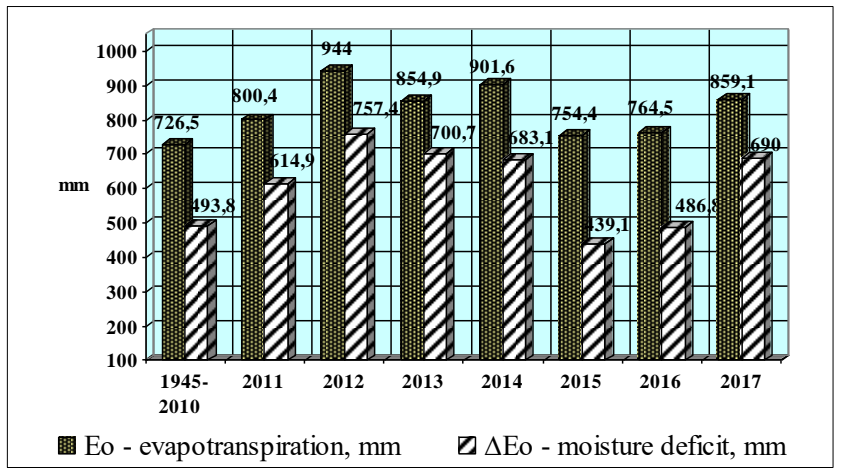

Fig. 6. Evapotranspiration (Eo) and moisture deficit ( $\Delta$ Eo) during the vegetation period (IV-IX months) of crops in the sub-zone of Southern Steppe (by the data of Kherson meteorological station) 
Under such weather conditions, which were during 2011-2017, there was an intensive spreading of the most harmful quarantine weed - ragweed (Ambrosia artemisifolia) - in Kherson region ${ }^{17}$ that caused significant decrease of the cultivated crops.

Together with significant effect on the crop formation, regional changes in climate at the end of XX and at the beginning of XXI century were also favorable for intensive development of agriculture in Southern part of the Steppe zone that is connected with high plowing rate of the agricultural land and their degradation ${ }^{18}$.

Systematic enlargement of the plow-lands in Ukraine during XX century resulted in unstable state of agricultural landscapes, plowing rate of which at the beginning of XXI century reached in the Steppe zone 81.3\%, and in a number of regions it is the highest in the world scale: Kherson $-90.2 \%$, Kirovohrad - 86.8; Mykolaiv - 84.6; Zaporizhzhia - 84.2; Dnipropetrovsk 84.0; Donetsk - 81.0; Odesa - 80.2 and Luhansk - 72.0\% (Fig.7).

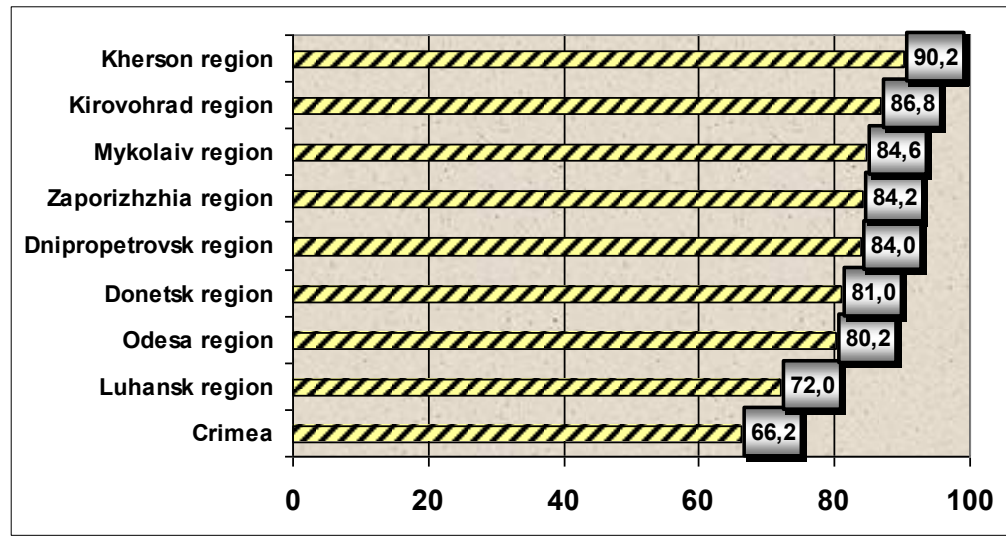

Fig. 7. Ratio of the arable land that is used in agriculture (arable land + perennial plantings) to the total agricultural land area in the regions of the Steppe zone of Ukraine, \%

In a number of districts of Kherson region plowed lands areas were much higher: Hornostaivka - 97.9\%; Nyzhni Sirohozy - 96.3; Velykolepetykha 96.0; Novovorontsovka - 94.6; Chaplynka - 94.0; Henichesk - 93.6;

${ }^{17}$ Косолапов Н., Андерсон Р. Как обуздать амброзию. Зерно. 2008. № 7. С. 60-66.

${ }^{18}$ Статистичний щорічник Херсонської області за 2006 рік. Херсон, 2007. С. 119-120. 
Kakhovka - 92.3; Verkhni Rohachyk - 92.0; Bilozerka - 91,5; Velykooleksandrivka -91.1 and Beryslav - 90.6\%.

The main reason of soil degradation as a complex of a number of negative processes that lead to significant decrease of fertility in the subzone of Southern Steppe of Ukraine are wind and water erosion, salinization, swamping, land use and pollution with radioactive elements.

Long-term use in Southern part of the Steppe zone of scientifically not proved systems of agriculture led to exceeded plowing of the soil surface, and, correspondingly, to the intensive soil erosion and irrational use of land resources in general.

At the total area of arable land of 15,528.7 thousand ha in connection with the excluded from the croplands forage crops, leguminous ones and perennial cereal herbs firstly, the area of eroded lands in the Steppe zone increased during the last years up to $8,636.8$ thousand ha, or $55.6 \%$ of the total arable land area (Table1).

Table 1

Areas of the eroded lands in the regions of the Steppe zone and in Ukraine on the whole, thousand ha ${ }^{19}$

\begin{tabular}{|c|c|c|c|c|c|c|}
\hline \multirow{2}{*}{ Region } & \multirow{2}{*}{$\begin{array}{c}\text { Agricultu } \\
\text { ral land }\end{array}$} & \multirow{2}{*}{$\begin{array}{c}\text { Arable } \\
\text { land }\end{array}$} & \multicolumn{4}{|c|}{ Eroded lands } \\
\cline { 4 - 7 } & & & \multicolumn{2}{|c|}{ Agricultural land } & \multicolumn{2}{|c|}{ Arable land } \\
\cline { 4 - 7 } & $1,798.4$ & $1,265.6$ & 999.3 & 55.6 & 919.3 & 72.6 \\
\hline Crimea & $2,514.3$ & $2,125.0$ & $1,104.8$ & 43.9 & 914.7 & 43.0 \\
\hline Dnipropetrovsk & $2,045.2$ & $1,656.0$ & $1,757.4$ & 85.9 & $1,080.0$ & 65.2 \\
\hline Donetsk & $2,247.7$ & $1,906.7$ & $1,212.5$ & 53.9 & 640.8 & 33.6 \\
\hline Zaporizhzhia & $2,039.9$ & $1,762.4$ & $1,102.4$ & 54.0 & 886.7 & 50.3 \\
\hline Kirovohrad & $1,911.1$ & $1,269.7$ & $1,372.3$ & 71.8 & $1,237.9$ & 97.5 \\
\hline Luhansk & $2,010.0$ & $1,698.1$ & 964.5 & 48.0 & 914.8 & 53.9 \\
\hline Mykolaiv & $2,593.4$ & $2,067.6$ & $1,214.0$ & 46.8 & $1,081.6$ & 52.3 \\
\hline Odesa & $1,971.1$ & $1,777.6$ & 686.2 & 34.8 & 961.0 & 54.1 \\
\hline Kherson & $\mathbf{1 9 , 1 3 1 . 1}$ & $\mathbf{1 5 , 5 2 8 . 7}$ & $\mathbf{1 0 , 4 1 3 . 4}$ & $\mathbf{5 4 . 4}$ & $\mathbf{8 , 6 3 6 . 8}$ & $\mathbf{5 5 . 6}$ \\
\hline Total & $\mathbf{4 1 , 5 9 5 . 1}$ & $\mathbf{3 2 , 4 6 1 . 4}$ & $\mathbf{1 5 , 9 5 3 . 9}$ & $\mathbf{3 8 . 4}$ & $\mathbf{1 2 , 9 4 0 . 3}$ & $\mathbf{3 9 . 9}$ \\
\hline $\begin{array}{c}\text { On the whole in } \\
\text { Ukraine }\end{array}$ & & & & & & \\
\hline
\end{tabular}

The consequent of the use in modern farming conditions of scientifically not proven system of agriculture is yearly increase of the areas with moderately and heavy washed out, deflation dangerous soils and the loss of land resources in general, where the degraded landscapes began to form. The latter is connected with disforesting of forest belts and forests.

${ }^{19}$ Балюк С. А., Медведєв В. В., Тараріко О. Г. та ін. Національна доповідь "Про стан родючості грунтів України”. Посібник украӥнського хлібороба. Київ, 2011. С. 41-69. 
As a consequent of intensive arable land use during the last years significant decrease of water interchange between the surface and subsurface waters occurred that is connected with the manifestation of water and wind erosion of soil causing the changes in the ratio of income and expenses shares of water balance. Due to the mentioned natural changes, in the recent years most regions of Southern part of the Steppe zone suffer from severe soil moisture deficit that is an obstacle for obtaining high crops ${ }^{20}$.

Together with high area of plowed land and not taking into account scientifically proven systems of agriculture, a significant effect on agricultural industry in the sub-zone of Southern Steppe regional change in climate occurred, especially in dry (95\%) years (Fig. 8).

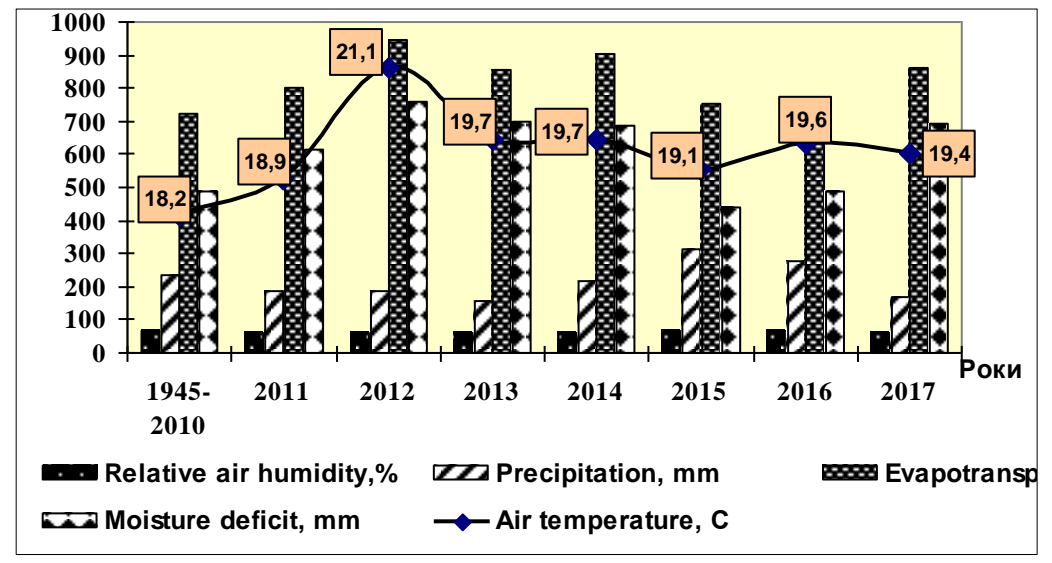

Fig. 8. Change of hydrothermal indexes during the vegetation period of crops in the sub-zone of Southern Steppe, on average for 1945-2010 and 2011-2017 (by the data of Kherson meteorological station)

The analysis of the average daily air temperature, conducted during the vegetation period of crops over the last 70 years in Southern part of the Steppe zone, shows that during 2011-2017, compared to the average of 65 years (1945-2010), it was significantly different. Herewith, the increase in average monthly air temperature occurred in the spring, summer and autumn. In the spring months (III-V), the air temperature was higher by $2.7^{\circ} \mathrm{C}$ or $28.4 \%$, respectively, in summer (VI-VIII, compared to the average

20 Комплексна галузева програма "Розвиток зерновиробництва в Україні до 2015 року” [Електронний ресурс]. Режим доступу: http://www.agro-business.com. ua/component/content / article/878.html?ed=55. 
long-term over the 65 years $(1945-2010)$. ) $-2.8^{\circ} \mathrm{C}$, or $12.9 \%$, and autumn (IX-XI) $-3.3^{\circ} \mathrm{C}$, or $32.3 \%$. Simultaneously with the increase in air temperature in the summer period of the year, the higher duration of the air temperature above $30^{\circ} \mathrm{C}$ increased significantly.

Thus, in the conditions of Kherson region in 2011, due to the amount of precipitation that fell during the autumn vegetation period of winter wheat equaled to only $25.1 \mathrm{~mm}$, the humidity coefficient did not exceed 0.07 that is usual for the desert. During the spring-summer period of its vegetation in 2012, with a rainfall of $65.6 \mathrm{~mm}$, there was also a significant shortage of moisture supply, resulting in extremely low winter wheat yields, and sometimes it completely died (Fig. 9).

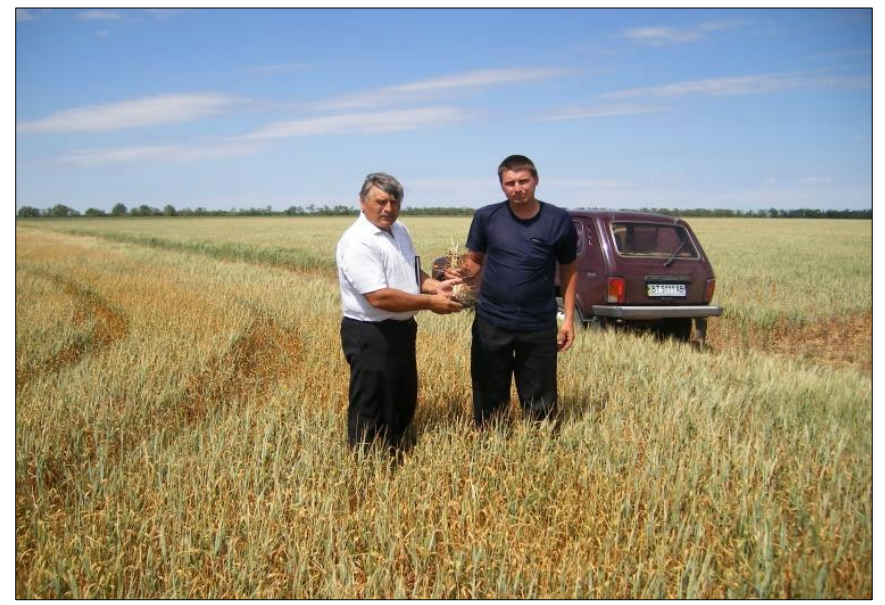

Fig. 9. Crops of winter wheat variety Kuialnik at the non-irrigated lands of State Enterprise Research Farm «Kopani» of the Institute of Irrigated Agriculture of NAAS in the conditions of air and soil drought in 2012

One of the maindirections that contribute in the current economic conditions to obtaining of high stable crops in Southern part of the Steppe zone is the optimization of the cropland structure and the increase of soil fertility. In developed countries of the world, this problem is solved by removing degraded and unproductive arable lan from intensive tillage, covering them with perennial leguminous herbs and legume-cereal herb mixtures and afforestation.

In this regard, long-term scientific research on the breeding of perennial leguminous herbs, the biological characteristics of which are most adapted to 
the natural and climatic conditions of the sub-zone of Southern steppe, have been carried out at the Institute of Irrigated Agriculture of NAAS. The studies showed that the accumulation of symbiotic nitrogen by alfalfa and sainfoins depended on the dry matter yield, nitrogen content in the plants, water supply deficits and the duration of the herbage use in years (Table 2).

Table 2

Accumulation of symbiotic nitrogen by alfalfa and sainfoins in Southern Steppe of Ukraine (average for the three years of the study)

\begin{tabular}{|c|c|c|c|c|c|c|}
\hline \multirow{2}{*}{ Indexes } & \multicolumn{3}{|c|}{ Alfalfa (Unitro) } & \multicolumn{3}{|c|}{ Sainfoins (Inhulskyi) } \\
\hline & $\mathbf{A}$ & $\mathbf{B i}$ & $\mathbf{A}+\mathbf{B i}$ & $\mathbf{C B}$ & & \\
\hline \multicolumn{7}{|c|}{ The first year of use } \\
\hline Nitrogen uptake by the crop: $\mathrm{kg} / \mathrm{ha}$ & 179 & 119 & 187 & 237 & 119 & 224 \\
\hline$\%$ & 150 & 100 & 157 & 199 & 100 & 188 \\
\hline Including biological, $\mathrm{kg} / \mathrm{ha}$ & 60 & - & 68 & 118 & - & 105 \\
\hline Nitrogen fixation coefficient, $\%$ & 33.5 & - & 36.4 & 49.8 & - & 46.9 \\
\hline Equivalent to mineral nitrogen: $\mathrm{kg} / \mathrm{ha}$ & 174 & - & 198 & 343 & - & 305 \\
\hline $\mathrm{GJ} / \mathrm{ha}$ & 15.1 & - & 17.2 & 29.7 & - & 26.5 \\
\hline \multicolumn{7}{|c|}{ The second year of use } \\
\hline Nitrogen uptake by the crop: kg/ha & 174 & 119 & 156 & 203 & 123 & 175 \\
\hline$\%$ & 146 & 100 & 131 & 165 & 100 & 142 \\
\hline Including biological, $\mathrm{kg} / \mathrm{ha}$ & 55 & - & 37 & 80 & - & 52 \\
\hline Nitrogen fixation coefficient, $\%$ & 31.6 & - & 23.7 & 39.4 & - & 29.7 \\
\hline Equivalent to mineral nitrogen: $\mathrm{kg} / \mathrm{ha}$ & 160 & - & 107 & 233 & - & 151 \\
\hline GJ/ha & 13.9 & - & 9.3 & 20.2 & - & 13.1 \\
\hline \multicolumn{7}{|c|}{ The third year of use } \\
\hline Nitrogen uptake by the crop: $\mathrm{kg} / \mathrm{ha}$ & 150 & 114 & 151 & 125 & 110 & 132 \\
\hline$\%$ & 132 & 100 & 132 & 114 & 100 & 120 \\
\hline Including biological, $\mathrm{kg} / \mathrm{ha}$ & 36 & - & 37 & 15 & - & 22 \\
\hline Nitrogen fixation coefficient, $\%$ & 24.0 & - & 24.5 & 12.0 & - & 16.7 \\
\hline Equivalent to mineral nitrogen: $\mathrm{kg} / \mathrm{ha}$ & 105 & - & 108 & 44 & - & 64 \\
\hline GJ/ha & 9.1 & - & 9.3 & 3.8 & - & 5.5 \\
\hline
\end{tabular}

Note: $A$-alfalfa; $B i$-bromus inermis; $A+B i$-alfalfa + bromus inermis; $S$-sainfoins; $S+B i-$ sainfoins + bromus inermis

The yield of absolutely dry matter of the herb mixtures of alfalfa + bromus inermis in the years of the study did not exceed 4.34-5.08 t/ha and sainfoins 3.86-6.12 t/ha. The nitrogen uptake by the crop depended on the species composition of plants and the year of use of the herbage and reached: alfalfa $-150-179 \mathrm{~kg} / \mathrm{ha}$, sainfoins $-125-237$; alfalfa herb mixture + bromus inermis - 151-187 and sainfoins + bromus inermis $-132-224 \mathrm{~kg} / \mathrm{ha}$.

In the first year of the herbage use, symbiotic nitrogen accumulation by the crops of single-species alfalfa reached $60 \mathrm{~kg} / \mathrm{ha}$ and $68 \mathrm{~kg} / \mathrm{ha}$ in the alfalfa herb mixture + bromus inermis, with a nitrogen fixation coefficient of $33.5 \%$ and $36.4 \%$, respectively. It was found that the accumulation of symbiotic nitrogen in the above-mentioned volumes by alfalfa and alfalfa herb mixture was equivalent to $174-198 \mathrm{~kg} / \mathrm{ha}$ of mineral nitrogen in the 
form of ammonium nitrate, or 15.1-17.2 GJ/ha of total energy. Sainfoins at a nitrogen fixation coefficient of $46.9-49.8 \%$ accumulated $105-118 \mathrm{~kg} / \mathrm{ha}$ of symbiotic nitrogen, equivalent to $305-343 \mathrm{~kg} / \mathrm{ha}$ of mineral nitrogen, or 26.5-29.7 GJ/ha of total energy.

In the second year of the use, symbiotic nitrogen accumulation in both alfalfa and sdainfoins was also high, reaching $37-55 \mathrm{~kg} / \mathrm{ha}$ in alfalfa and $52-80 \mathrm{~kg} / \mathrm{ha}$ in sainfoins, with a nitrogen fixation coefficient of $23.7-31.6 \%$, and $29.7-39.4 \%$, respectively. Symbiotic nitrogen accumulation of alfalfa in the mentioned volumes was equivalent to mineral within $107-160 \mathrm{~kg} / \mathrm{ha}$, or 9.3-13.9 $\mathrm{GJ} / \mathrm{ha}$ of total energy against $151-233 \mathrm{~kg} / \mathrm{ha}$ in sainfoins, or 13.1-20.2 GJ/ha of total energy.

In the third year of the perennial legumes herbage use, accumulation of symbiotic nitrogen by alfalfa decreased to $36-37 \mathrm{~kg} / \mathrm{ha}$ and to $15-22 \mathrm{~kg} / \mathrm{ha}$ at sainfoins, which is connected with the changes in the species botanical composition of the sown herbs. Due to a significant decrease of the part in the botanical composition of speciesboth in the single-species and herb mixtures of sainfoins, accumulation of symbiotic nitrogen in a mineral form equivalent in sainfoins was only $44-64 \mathrm{~kg} / \mathrm{ha}$ or $3.8-5.5 \mathrm{GJ} / \mathrm{ha}$, against $105-108 \mathrm{~kg} / \mathrm{ha}$ at alfalfa, or $9.1-9.3 \mathrm{GJ} / \mathrm{ha}$ of total energy.

\section{CONCLUSIONS}

The intensive pace of global and regional climate change in the sub-zone of Southern Steppe is now significantly exacerbated, which is manifested by the increase in average annual air temperatures, extreme weather phenomena, including droughts, which cover up to 50-70\% of its territory. Alongside with the significant impact of global climate change on the formation of high yields, the extremely high plowing of existing agrolandscapes also led to their degradation.

The cultivation of mono-species crops of alfalfa and sainfoins and their herb mixtures with bromus inermis in the three-year period of their use allowed obtaining green forage, balanced with digestible protein without mineral fertilizers, and having the best previous crops for cereals during the three years of their cultivation.

Creation of high-yielding mono-species crops of perennial leguminous herbs and binary legume-cereal herb mixtures contributed to a significant increase in the content of mineral and alkalinely hydrolyzed nitrogen compounds, the improvement of the physical and physico-chemical properties of soils and, first of all, the significant diminishing of the catastrophic effect of natural phenomena, connected with global and regional climate change. 
Therefore, increasing soil fertility and their protection at the moment in the sub-region of Southern Steppe, as well as in Ukraine on the whole, is one of the most important fundamental problems, solving of which will ensure long-term sustainable development and high productivity of agro-ecological systems under the preservation of agricultural agrolandscapes, their soil cover.

\section{SUMMARY}

The analysis of global climate change and its influence on the increase of hydrothermal indicators during the vegetation period of crops in Southern Steppe of Ukraine was carried out. It was found that the average rainfall during 2011-2017 in the moderately dry (75\%) and dry (95\%) years was significantly lower and averaged to $154.2-186.6 \mathrm{~mm}$ versus $232.7 \mathrm{~mm}$ in the average for the years 1945-2010. The decrease of precipitation amounts in the last years in the spring by $24-27 \%$ and in the autumn by $62-65 \%$, with a simultaneous increase in temperature and decrease in the relative humidity in these seasons by $2.7-2.8^{\circ} \mathrm{C}$, led to an increase in evapotranspiration by 30 $31 \%$ and a deficit in water supply by $53-55 \%$. It is proved that the increase of soil fertility in the sub-zone of Southern Steppe, as well as in Ukraine on the whole, is one of the most important fundamental problems, solving of which will ensure long-term sustainable development and high productivity of agro-ecological systems under the preservation of their agrolandscapes, and first of all, of their soil cover. The feasibility of the creation of monospecies crops of alfalfa and alfalfa-cereal herb mixtures has been substantiated, which will significantly increase the content of mineral compounds of nitrogen and reduce the catastrophic impact of natural phenomena associated with global climate change. Efficient use and further expansion of the cropland areas under alfalfa in the conditions of global climate changes will contribute to the enhancement of soil fertility, higher crops, which will provide stable food security for the population of Ukraine.

\section{REFERENCES}

1. Исследования межгосударственной группы экспертов при ООН. [Электронный ресурс]. Начало повышения температуры на планете. Режим доступа: Internet resources: http://ru.wikipedia.org/wiki/.

2. Влияние парниковых газов на глобальное изменение климата. [Электронный pecypc]. Причины нагревания поверхности Земли. Режим доступа: Internet resources: http://www.referatik.com.ua/subject/97/ $41350 /$ ?page $=2$. 
3. Гидрологический словарь. Под ред. В.М. Котлякова. Л. : Гидрометиздат, 1984. 527 с.

4. Концентрация углекислого газа в атмосфере. [Электронный pecypc]. Изменение структуры агроландшафтов. Режим доступа: Internet resources: http://enrin.grida.no/htmls/tadjik/ntalgraphics/rus/ html/climate.htm.

5. Источники загрязнения атмосферы. [Электронный ресурс]. Ежегодные выбросы парниковых газов. Режим доступа: Internet resources: http://www.ukragroconsult.com/contentview/46301/61/.

6. Поглощение инфракрасной радиации. [Електронний ресурс]. Причины увеличения концентрации парникових газов. Режим доступу: www.un.org/ru/documents/decl_conv/conventions/agenda21_ch12b.shtml.

7. Мачерет Ю.П. Радиозондирование ледников. М.: Науч. мир, 2006. $392 \mathrm{c}$.

8. Причины увеличения метана в атмосфере. [Электронный ресурс]. Наличие градиента концентрации метана в межледниковые периоды. Режим доступа: Internet resources: http://www/lib/ua-ru/net/inode/p2/14290.html.

9. Природная изменчивость процесса Солнце-Земля. [Электронный pecypc]. Циклы изменения климата. Режим доступа: Internet resources: http://www.ukrindustrial.com./news/index.php.?newsid=219087.

10. Уменьшение площади ледников Арктики. [Электронный pecypc]. Усиление эрозии морских берегов. Режим доступа: Internet resources: http://www.zn.ua/3000/3320/63430/.

11. Фазы ледниковых периодов. [Электронный ресурс]. Продолжительность зимних периодов в Европе. Режим доступа: Internet resources: http://www.podrobnosti.ua.health/2008.08.22/548886. html.

12. Аномальне похолодання в Европе. [Электронный ресурс]. величение продолжительности зимного периода. Режим доступа: Internet resources: http://www.grida.no/climate/ipec_tor/vol14/russian/ 083.htm

13. Палеонтологические исследования. [Электронный ресурс]. Причины вымерания отдельных видов растений и животных. Режим доступа: Internet resources: http://imm.org.ua/se/news/index.php? action $=$ show $\&$ nid $=4163$

14. Bentley R. W. «Глобальное истощение нефти и газа: обзор». Energy Pochy. 2002. № 30. C. 189-205. 
15. Киотский протокол. [Электронный ресурс]. Ограничение выбросов парникових газов на планете. Режим доступа: Internet resources: http: // echo. msk.ru/news/511753-echo.html.

16. Иванов Н. Н. Показатель биологической эффективности климата. Известия Всесоюзного географического общества. 1962. Т. 94. Вып. 1. С. 65-70.

17. Косолапов Н., Андерсон Р. Как обуздать амброзию. Зерно. 2008. №7. C. 60-66.

18. Статистичний щорічник Херсонської області за 2006 рік. Херсон, 2007. С. 119-120.

19. Балюк С. А., Медведєв В. В., Тараріко О. Г. та ін. Національна доповідь "Про стан родючості грунтів України". Посібник украӥнського хлібороба. Київ, 2011. С. 41-69.

20. Комплексна галузева програма "Розвиток зерновиробництва в Україні до 2015 року" [Електронний ресурс]. Режим доступу: http://www.agro-business.com.ua/component/content/article/ 878.html?ed=55.

\section{Information about the author:} Holoborodko S. P., Doctor of Agricultural Sciences, Professor, Chief Researcher, Institute of Irrigated Agriculture of the National Academy of Agrarian Sciences of Ukraine Kherson, Naddniprianske, 73483, Ukraine 
DOI https://doi.org/10.36059/978-966-397-154-4/67-83

\section{IRRIGATION - A KEY TOOL OF AGRICULTURAL DEVELOPMENT AND MINIMIZATION OF THE EFFECT OF CHANGES IN CLIMATE ON SOCIO-ECONOMIC DEVELOPMENT OF UKRAINE}

\section{Hranovska L. M.}

\section{INTRODUCTION}

Irrigation is one of the main ways of effective sustainable agriculture in Southern region of Ukraine and of reduction of its dependence on the influence of natural and climatic conditions. Irrigation contributes to the reduce or even complete elimination of water balance deficit, increases crop yields by almost 3-5 times and ensures food security of Ukraine. To ensure the development of irrigated agriculture and meet the needs in water resources, a powerful water-meliorative complex was built in Ukraine, which is one of the most powerful segments of the economy. It is represented by a large number of water, meliorative and engineering objects and the related infrastructure.

On the one hand, the development of irrigated melioration leads to significant changes in the intensity and orientation of natural processes, and on the other - irrigated melioration is one of the important factors of the economic efficiency of the agrarian sector and a condition for ensuring sustainable agricultural production, especially in years with unfavorable natural and climatic conditions. Food security, economic and social situation in the region and in the country on the whole depend to a large extent on the efficient use, conservation and reproduction of the fertility indexes of the irrigated lands. Therefore, the question of restoration and further development of irrigated agriculture is considered in the context of the modernization of the water sector and the improvement of institutional support for the development both of water-meliorative complex and the agrarian sector of the economy.

\section{Theoretical aspects of water management in irrigated agriculture}

During the 1950's and 1970's, a water-meliorative complex was created in Ukraine, which is represented by powerful, by its content, and extremely complicated, by its technical saturation, water and meliorative objects. The 
complex includes national and inter-farm systems, internal economic network, hydrotechnical objects and structures, has a complex engineering infrastructure and technological organization of process management, related to the abstraction and transportation of water from the irrigation source, conduction of irrigation, water divertion, artificial drainage of land.

Privatization processes in the system of land use and land ownership have caused an increase in the number of owners of irrigated areas, have led to the fragmentation of irrigation systems and breaking technological connections in the water supply and water divertion system. The conditions of exploitation of irrigation systems and the efficiency of farming at the irrigated agricultural land have significantly deteriorated. Besides, global climate change has been observed in recent years, which has a negative impact on the economic efficiency of the agrarian sector of the economy. At the same time, scientists note an increase in the area of agricultural land, which have a hydrothermal coefficient from 0.65 to 0.95 , which necessitates the construction of irrigation systems to eliminate the water balance deficit in these regions.

In recent years, EU countries have also been concerned about the scarcity of water resources in the conditions of global changes in climate, as these environmental conditions in many regions have led to increased degradation and desertification of agricultural land. In 2012, the European Commission carried out a general assessment of water policies in the countries in regard to water scarcity and increased droughts. The main work of the Commission is to analyze the integration issues of water scarcity and droughts in the world, which is negative for the agrarian sector of many countries. The analysis of the Commission gives all the reasons to assert that the issues of rational use, protection and reproduction of water resources are relevant for all countries of the world ${ }^{1}$. Such features are typical for Southern region of Ukraine.

Scientific developments of foreign scientists in the questions of the rational use of water resources, the need for reconstruction of irrigation in EU countries are directed to the improvement of the efficiency of agriculture conduction, the formation of a stable water policy and food security. Thus, the experience of Bulgaria, as noted by Hadzieva V. ${ }^{2}$, shows that it is

\footnotetext{
${ }^{1}$ Communication from the Commission to the European Parliament, the Council, the European Economic and Social - European Commission. Brussels, 16.4.2013.COM(2013) 216final.11p. Retrieved from http://ec.europa.eu/transparency/regdoc/ rep/1/2013/EN/1-2013-216-EN-F1-1.Pdf.

2 Hadzieva V. Condition, problems and opportunities of irrigated agriculture after / Bulgarians to the European union-Rural Economics and Management, 2007. Vol. 52. C. 85-89. https://jcea.agr.hr/articles/774129_Bulgarian_agriculture_in_the_conditions_of_the_EU_ Common_Agricultural_Policy_en.pdf.
} 
necessary to carry out institutional reform of the water sector in order to prevent the Bulgarian situation of declining in the irrigation sector. Chandra A. Madramootoo ${ }^{3}$ notes that the occurrence of problematic situations in the further functioning of water economy in the countries that have undergone stages of socio-economic transformation, are linked with the fact that institutional transformations of water economy and management systems did not occur in socio-economic transformations in water economy. And this has led to environmental, technological, meliorative and economic problems.

The questions of rationsl use and protection of water resources, especially in the conditions of global climate change and more frequent occurrence of droughts even in the countries where it was not typical, are becoming increasingly relevant. Important contribution to the solving of this problem was made by domestic and foreign scientists, their scientific developments are relevant and scientifically substantiated, for example, academician of NAAS Romashchenko ${ }^{4}$, academician of NAAS P.I. Kovalenko and Chandra A. Madramootoo ${ }^{3,5}$, scientists Reinders F.B. and Nimkale V.E. All these scientists scientifically substantiate the directions of increasing the efficiency of water resources use and provide practical recommendations on the rational use of water resources, the use of micro irrigation and drip irrigation as resource-saving ways of watering crops and improving water policy in general ${ }^{6,7}$. The European Commission is focusing the attention of scientists on the need to improve water policy in regard to the climate change. O. Zhovtonog, W. Dirksen, K. Roest analyze water reforms of different countries of the world and develop possible directions for the reformation of water policy in Ukraine ${ }^{8}$.

${ }^{3}$ Chandra A. Madramootoo. Water Management for Global Food Security/ McGill University, Macdonald Campus, 21,111 Lakeshore Road Ste. Anne de Bellevue QC H9X 3V9, Canada. (2011). 136 p. Retrieved from https://www.mcgill.ca/macdonald/ GFS_Seminar_ Cafiero

${ }^{4}$ Концепція відновлення та розвитку зрошення в Південному регіоні України / за редакцією д.т.Н., академіка НААН М.І. Ромащенка. К.: ЦП «Компринт», 2014. 30 с.

${ }^{5}$ Коваленко П.І. Актуальні проблеми використання водних ресурсів і меліорованих земель на сучасному етапі. Міжвідомчий тематичний науковий збірник «Меліорація $i$ водне господарство». Київ, 2011. Вип. 99. С. 5-16.

${ }^{6}$ Felix R. Reinders. Sustainable Micro Irrigation Principles and Practices / Edited by Megh R. Goyal, Vishal K. Chavan and Vinod K. Tripathi. Citation Information Principles and Management of Clogging in Micro Irrigation. Apple Academic Press, 2015. Pp. 21-30. https://www.crcpress.com/Sustainable-Micro-Irrigation-Principles-andPractices/Goyal/p/book/978177

${ }^{7}$ Ромащенко М. І., Жовтоног О. І., Сагайдак Р. В., Книш В. В. Управління процесом відновлення та сталого використання. Меліорація $i$ водне господарство. Київ, 2014. Вип. 101. С. 137-147.

${ }^{8}$ Zhovtonog O., Dirksen W., Roest K. Comparitive Assesment of Irrigation Sector Reform in Central and Eastern European Countries of transition. GTZ. 2003. Pp. 19-38. 
Scientific researches of domestic scientists are also directed to the solving of the tasks determined by the Cabinet of Ministers of Ukraine Decree No. 271-p dated March 30, 2016 "On Approval of the National Action Plan for Combating Land Degradation and Desertification" and to the developing of scientifically based proposals for the reconstruction and development of irrigation in Ukraine (paragraph 20), the ensuring of technological integrity of the engineering infrastructure of irrigation systems in accordance with the requirements of the Law of Ukraine «On Land Reclamation» (paragraph 22), the development and introduction of modern environmentally friendly, landscape-adaptive, soil-protecting, energy- and resource-saving technologies for the purpose of ecologically-balanced use, protection and regeneration of lands and soils, the prevention of their degradation (p. 25) .

Deficit of natural humidification is observed the last years, which are characterized by by the scientists as the years of global climate change. Under these conditions, sustainable development of the agrarian sector of the economy is impossible without taking steps in artificial regulation of the water regime of soils - irrigation. Food security at the national level is closely connected with the concept of food independence (self-sufficiency), the state of security of meeting food demands at the expense of the required level of own production. The system of national food security, according to the legislative and regulatory acts of Ukraine, is based on the following principles: self-sufficiency, independence, accessibility, quality. These principles are taken into account in the formulation of the state policy on food security, and also provide its directions such as the effective development of the agrarian sector of the economy, the formation of income of the population, the guarantee of balanced and qualitative food and the development of rural territories.

\section{Irrigation as a factor of economic development of agrarian sector of economy and rural territories}

Irrigation is one of the main directions of intensification of agricultural production in the regions with insufficient humidification. The system of irrigated agriculture includes a complex of measures such as: agro-technical, agro-meliorative and organizational. At irrigation, favorable conditions for crops cultivation at the lands of Southern region of Ukraine are created. Irrigation of land in the conditions of insufficient water supply allows increasing crop yields by several times. Properly designed irrigation systems

\footnotetext{
${ }^{9}$ Постанова Кабінету Міністрів «Про затвердження національного плану дій щодо боротьби 3 деградацією земель та опустелюванням. 2016. № 271-р.
} 
provide long-term stabilization of the water regime. Leaching saline lands with fresh water restores fertility and reduces degradation processes. However, there are negative environmental consequences of the use of meliorative measures in dependence on the quality of irrigation water, irrationality of irrigation regime and poor technical condition of engineering irrigation systems.

Irrigated meliorations, increasing soil productivity and providing conditions for obtaining guaranteed crops, transformed into a valuable factor of the stabilization of agricultural production. And from these positions, there is no alternative to irrigated agriculture in the South of Ukraine, especially in extreme weather conditions ${ }^{10,11}$.

A significant negative effect on agricultural development was made by food intervention, which led to the reduction of the livestock industry and, consequently, the need for forages, significantly changed the structure of croplands on the irrigated lands. The distribution of each irrigated land mass into small areas as a result of land splitting also led to a decrease in the efficiency of the use of meliorative systems.

An important economic factor that determines the need in restoration and increase of the area of irrigated lands is the demand for food in the country, the production of which without irrigation in the conditions of insufficient natural humidification is impossible. The solution of environmental problems in the use of agricultural land is at the same time the task of sustainable land use, a tool for economic growth, technological restructuring of the agrarian sector of the economy to meet the material and spiritual needs of the population.

An integral index of the ecological and meliorative status of irrigated soils and the optimality of their use in the system of irrigated agriculture is the yield of crops, and the compliance of agricultural products with ecological requirements to quality. The results of a comparative analysis of the efficiency of agricultural activities in cultivation of main crops at irrigation and without irrigation in the region show that irrigation is a factor of economic growth not only for agricultural enterprises, but also for rural areas and the rural region on the whole. The structure of the expenditures for crops cultivation in the irrigated conditions depends on the biological features of crops and their requirements for soil moisture. However, the decline in the efficiency of irrigated land was also due to the increase in the

\footnotetext{
${ }^{10}$ Проект Стратегії розвитку зрошення та дренажу. Київ, 2017. 56 с.

${ }_{11}$ Вожегова Р. А., Димов О. М., Грановська Л. М. Нормативи витрат матеріальнотехнічних ресурсів при вирощуванні основних сільськогосподарських культур: науковометодичне видання. Херсон: Грінь Д.С., 2014. 64 с.
} 
cost of electricity, natural and material resources, fertilizers, chemical plantprotecting agents, disparity in prices for agricultural products.

In order to increase the economic efficiency of agricultural production on irrigated lands and to take full account of environmental factors, it is desirable to envisage changes in the existing legislation governing economic activity on irrigated lands, namely: to justify state support for crop production on irrigated lands, it is necessary to take into account the existing ecological and meliorative state of the irrigated lands. The basis for this is a certificate given to water consumers by a hydrogeological-meliorative expedition.

Taking into account this requirement, the use of funds, provided in the state budget for the state support of crop production on irrigated lands, can be a factor of influence on agricultural producers not only in the form of state support for the use of irrigated land, but also theough the stimulation of water consumers to take steps for the improvement of the ecological and meliorative status of the irrigated lands, their rational use and protection.

\section{Institutional guarantee of rational water use in irrigated agriculture}

The efficiency of the water-meliorative complex and the development of the agrarian sector of the economy in the area of insufficient natural humidification depends on the institutional environment that regulates the system of water and land use. National scientists P.I. Kovalenko ${ }^{5}$ and M.I. Romashchenko ${ }^{12,13}$, M.A. Khvesik ${ }^{14}$, Doctors of Sciences O.I. Zhovtonoh ${ }^{8}$, V.A. Golyan ${ }^{14}$ has already formed the main directions of the research of meliorative and ecological-economic issues of rational use and management of water resources, and developed mechanisms for reforming the water management complex in accordance with modern economic conditions. Despite the large amount of researches and developments in this field, there are a lot of problems. The issues of transformation of property relations into land reclamation systems and objects, which were built at the expense of state capital investments, as well as the issues of institutional regulation of water management and irrigation complex and the system of irrigated agriculture, are unsolved.

According to the Law of Ukraine «On Land Reclamation», the subjects of property relations on the meliorated land in the modern economic

\footnotetext{
${ }^{12}$ Ромащенко М. І. Концептуальні засади відновлення зрошення у Південному регіоні України. Меліорація і водне господарство. Київ, 2013. Вип. 100. С. 7-17.

${ }_{13}^{13}$ Ромащенко М. І. Наукові засади розвитку зрошення земель в Україні. К.: Аграрна освіта, 2012. 28 с.

${ }^{14}$ Хвесик М. А., Голян В. А. Інституціональна модель природокористування в умовах глобальних викликів: монографія. К.: Кондор, 2007. 480 с.
} 
conditions are: the state, which owns a nationwide and inter-economic irrigation network; district offices on whose territory inter-economic irrigation systems are located; village and settlement councils to which the land reclamation network was transferred; agricultural enterprises and farms, as well as individuals who use the meliorated land and rent meliorative systems on these lands ${ }^{15}$.

However, the rights on command and use of the inter-farm meliorative network remain unsettled, as land users do not own the hydraulic structures and network elements, but only exploit them. Such a system of relations does not resolve the question of who should be responsible for the proper condition of domestic networks and structures. It is difficult for agricultural producers to exploit their meliorative systems on their own, due to a lack of funds and skilled personnel. The situation is complicated by the fact that the owner of the national and inter-economic network is the state, and the number and composition of water users on this network is constantly changing. Under such conditions, meliorative systems cannot fully fulfill their functions. Further development of irrigation and irrigated melioration requires the transition of the water economy branches and irrigated agriculture to an innovative model of development based on ecological and economic principles, first of all resource conservation, energy conservation and restoration of the potential of land and water resources, systematics, complexity, orientation on the satisfaction of needs and requirements of water consumers with taking into account environmental constraints. The innovative model of irrigated agriculture development envisages fundamentally new approaches of organizational, economic, technological, technical, regulatory direction regarding the nature of the use of irrigated land, water resources and irrigation systems.

Unlike technical and technological innovations, implementation of organizational and economic innovations requires changes in the institutional environment, transformations in the organizational structure of the water economy and meliorative complex, agricultural enterprises and the bodies of state authorities. The issue of consolidation of agricultural land within irrigated arrays remains of current importance. On March 22, 2017, a meeting of the Committee on Agrarian Policy and Land Relations of the Verkhovna Rada of Ukraine was held on the topic: "Consolidation of land plots located in arrays of agricultural land». The results of the committee's work have shown that today, due to the increase in the number of individual land users, the efficiency of agricultural land cultivation and reclamation is

\footnotetext{
15 Закон України «Про меліорацію земель» від 19.10.2016 р. [Електронний ресурс]. Режим доступу: http://zakon3.rada.gov.ua/laws/show/1389-14
} 
decreasing, and conflicts of interest between landowners and land users or tenants are constantly emerging. The causes of the conflicts are the sharing of agricultural land, the transfer of it to private property, the imperfect system of land rent and the imperfect system of legislative and normative regulation of these processes.

The Law of Ukraine «On Amendments to Certain Legislative Acts of Ukraine on Resolving the Issue of Collective Land Ownership, Improvement of Land Use Rules in Agricultural Land Arrays, Prevention of Raiding and Encouragement of Irrigation in Ukraine» provides for a number of actions aimed at consolidating agricultural land, ensuring proper ecological and meliorative state of agricultural land, irrigation water quality and biological requirements of crops, and also it is aimed at preventing the development of degradation processes of soils by setting land use standards, environmentally friendly irrigation, drainage and watering or water divertion management ${ }^{16}$. It is the first legisaltive document, which is directed to the improvement of institutional regulation of economic activity at the irrigated lands.

The first bases of the formation of institutionalism were laid in the economic theory of the German School of History (F. List, D. Knys, K. Blucher, M. Weber) ${ }^{14}$. Significant propagation institutionalism obtained in Anglo-American science. As a whole, institutionalism was more deeply conceived and explored in the United States as a protest form to the postulates of classical and neoclassical market economy theory, which was planned on the virge of XIX-XX centuries. Institutionalism is a complex formation both by the direction of investigations and in the achievements in the learning of economy and society. Institutionalism is a leading field of economic science that determines the factors of economic development, taking into account the spectrum of economic, political and social changes.

The category «Institutional environment» is interpreted by a number of scientists, and their interpretations are sometimes significantly different from each other. Some of them believe that the institutional environment consists of formal and informal rules, formal and informal constraints, mechanisms of compulsion that determine institutional changes, while others interpret the institutional environment as a system of norms and rules that is initiated in the economic sphere and admitted by society, that is it recognizes only fundamental institutions, accompanying the business process. We consider it to be necessary to interpret the term «institutional environment» as a set of institutes and institutions, which form the set of economic, environmental,

\footnotetext{
${ }^{16}$ Проект Закону України «Про внесення змін до деяких законодавчих актів України щодо вирішення питання колективної власності на землю» [Електронний ресурс]. Режим доступу: http://search.ligazakon.ua/__doc2.nsf/link1/JH4O11AA.html
} 
social, legal rules and norms on which production is based and the basic direction of economic systems development is determined ${ }^{17}$.

During the whole period of institutionalism development, there were many interpretations and concepts of the terms «institute» and «institution» arisen. A large number of scientists have combined these concepts, while others have given them different interpretations. The most faithful, in our opinion, is D. North's proposal to differentiate between two concepts: «institutions» should mean laws, rules, customs, norms, and «institutes»organizations, i.e. state bodies, political parties, trade unions, etc., which form, conduct and control these institutions. For D. North, the first is the rules that determine how to "play», the second is purely actors whose competence extends only to the formulation of development strategies and the skill and professionalism in applying the relevant institutions. For the main feature of institutions, D. North proposes to take their ability to determine and limit the set of choices of individuals, and for the main function - to reduce uncertainty by establishing a permanent structure of human interaction in a particular sphere ${ }^{18} 19$.

The contradictions, restraining the effective innovative development of agrarian enterprises of different organizational and legal forms in irrigated agriculture today, originate from the inefficient institutional support of irrigated agriculture. They can be formed as follows:

- the cost of production is growing at a much higher tempo than the price of selling agricultural products. The consequence is price disparity, which reduces the attractiveness of the agrarian sector for investment;

- decrease in quality of agricultural products and producers' incomes, low labor productivity and low competitiveness of products and branches of the agricultural sector of the economy;

- imperfect and unclear credit system for agricultural production;

- there is no legislative adaptation to market conditions for the functioning and further development of the agricultural sector of the economy;

- non-market institutional relations between landowners and enterprises - lack of trust, protection of peasant's rights and awareness of the

17 Грановська Л. М., Жужа П. В. Екологічний аудит земель, що зрошуються в контексті їх сталого використання. Зрошуване землеробство: міжвід. темат. наук. зб. Херсон: Грінь Д.С., 2017. Вип. 67. С. 24-27.

${ }^{18}$ North D., Thomas R.P. The Rise of the Western World: A New Economic History, Cambridge, Cambridge University Press. 1973. - Pp. 101-105.

19 Дж. Норт. Институты, институциональные изменения и функционирование экономики. Перевод с английского А.Н. Нестеренко. Предисловие и научное редактирование Б.З. Мильнера. Фонд экономической книги «НАЧАЛА». МОСКВА, 1997. C. 17. 
temporality of agricultural business, which is based and functions not on own but borrowed land and property assets.

Hence, the main directions of institutional transformations in irrigated agriculture, which will ensure the efficiency of functioning of agricultural enterprises of different organizational and legal forms of land and property management, are:

- increase of the efficiency of production in irrigated agriculture as a component of the country's economy and the conditions for ensuring food security;

- investing innovations directed to the resource conservation, rational environmental management and environmental safety in the agrarian sector of the economy of the irrigated zone;

- protection of the rights of the investors of innovative projects in the agrarian sphere in the conditions of different risk groups and uncertainties;

- ensuring extended reproduction of human capital;

- protection of the rights on land resources and property;

- organization of struggle against corruption and raiding in agrarian sphere;

- restoration and extension of the irrigated areas of agricultural lands and modernization of water economy and meliorative complex;

- provision of institutional transformations in the system of the agrarian sector of the economy and water-meliorative complex of Ukraine.

Adaptation of the institutional approach specifically to the system of irrigated agriculture includes the main institutes that ensure the rational use of nature and environmentally-friendly development of the industry are: institutes of power, economy, ecology, law and society. Besides, corresponding institutions, which largely depend on the activities of the institutes, are important, and they provide efficient organizational and functional links within the institutes and restrictive frameworks and the rules of the game, whic hare based on formal laws and regulations. The next element of the environment is informal institutions, which include values, traditions, related to the culture, education, mentality and mindset of society.

One of the important institutes that regulates the activities of agrarian enterprises and creates an appropriate environment for the innovative development of various agricultural enterprises is the institute of power. The Institute of power is the basic institute and includes the whole system of power relations: political power, which is formed on the relations of the owner of the means of production and subordinates; economic power as the subordination of the production process participants to the interests of the owner of the means of production; spiritual power, which is directed to the 
leading creative interests of society to the realization of socially significant values.

Depending on the sphere of social relations, there are economic institutes, which include, for example, ownership of natural resources and property; taxation of activities, use of natural resources, profit; cooperation and division of labor, lending, entrepreneurship and business; investment and innovative activity; market; banking and insurance, etc.

The Institute of ecology is not less important in the system of natural management, functions of which are regulation and control of the system of natural management through the following directions: use, reproduction and protection of natural resources; licensing and certification of environmental management; environmental safety of natural management; system of penalties and sanctions for irrational use of nature; monitoring of the state of the environment; measures for environmental protection, etc.

The institute of law is an external mechanism for the control of the activities of the institutes, and also for the formation and implementation of institutional norms in the system of agrarian natural management.

The social institute provides the development of scientific activity, the level of education, joint activity and living and health conditions of the population. The institute forms the labor and employment market; affects the processes of demographic regulation, and also ensures compliance with the requirements of social standards in the country. The social institute is necessarily involved in the transformational processes of institutional support of the sustainable development of the country and its regions.

The activity of the institutes at different levels of management of the agrarian sector (national, regional and local) is carried out, regulated and controlled with the help of legislative and regulatory support, which is developed and implemented in economic activity by various institutes. Besides, the activity of the institutes is ensured by organizational and functional links in the structures of each institute and between them, as well as through formal institutions. At the same time, informal institutions have a direct influence on the institutional environment and have to change in the process of improving the latter.

All the institutes function through an institutional mechanism, which is an integral part of the economic mechanism, which creates organizational, functional and legislative and regulatory conditions for stable work of economic entities.

Institutional support for the development of agrarian enterprises of different organizational and legal forms of economic activity, which develop on the basis of innovations, includes: institutional support for land use; 
institutional support for water use; institutional support for the development of the agrarian sector of the economy and rural areas in the zone of irrigation; institutional support of the state system of management of the agrarian sector of the economy and water-meliorative complex.

The efficiency of the activity of agrarian enterprises depends to a large extent on their provision with financial resources. In the conditions of inflationary processes, most agricultural enterprises do not have sufficient own funds for innovative development, and therefore are forced to attract financial resources from other sources, in particular in the form of loans.

The researches show that loans are predominantly unavailable for the enterprises of the agrarian sector. One of the main reasons for this is very high credit usage fees. Other limiting factors for obtaining credits are high requirements of banks for pledge, «short» credit payment, low level of creditworthiness of agricultural enterprises, etc. Economic activity of agrarian enterprises has a direct dependence on the natural and climatic conditions. The insurance system can to some extent reduce the influence of natural factors on the loss of funds of the enterprise. At the same time, studies show that the unavailability of insurance services for agricultural companies at their high cost, the small choice of insurance services and the reduction of insurance premiums restrict the development of the insurance market in the agrarian sphere.

Today, in the agrarian sphere it is impossible to refuse state support of separate sub-branches of plant growing and animal husbandry. The state should clearly identify the direct recipients of this assistance. This is how most countries in the world work.

In many countries, the tax system is not focused on collecting VAT on agricultural products, and agricultural products are virtually non-taxable: the principle is that value added tax should not be paid at every stage of product distribution, but at its final stage when the product obtains its final consumer cost. It is economically more fair and, at the same time, it is a regulation of consumption $^{20}$.

Studies show that today there is no stable and unified mechanism of taxation in the agrarian sphere of Ukraine. For almost twenty years, the search for a system of taxation of agricultural producers has been taking place, which leads to constant changes in the system of taxation. However, it is undebatable that there is a need to apply a single approach to taxation for agricultural enterprises, regardless of their legal form and size of land plots, and the object of taxation has to be profit. Differentiated income tax rates

20 Фінансова політика в аграрному секторі економіки: стан та перспективи / За ред. проф. Д.І. Деми. Житомир: ЖНАЕУ, 2015. 364 с. 
prevent most controversies and discussions about the taxation system in the agrarian sector of the economy.

Financial resources are one of the most important factors in the economic recovery and growth of an enterprise. They ensure the continuity of the process of reproduction by financing the running costs of the enterprise and fulfilling obligations to the state, employees and other economic entities; capital insurance against possible financial risks through diversification of forms of financial resources; stable development and business reputation of the enterprise; stimulation of profitability improvement; social development of the enterprise as a whole and its employees.

State regulation of the agrarian sector of the economy in foreign countries is one of the levers of agrarian and financial policy in agriculture. An EU country with a high level of state support for agriculture and its diversity is Poland. Here the laws of the market are combined with a considered state agrarian policy directed to supporting and assisting agricultural producers by setting a certain level of storing prices, export delivery dates, limiting the production of certain types of agricultural products, stimulating the development of rural areas, etc.

Based on the presented analysis, it is possible to form powerful blocks of state support for agricultural enterprises of different organizational and legal forms, which, with the help of an institutional mechanism and an appropriate environment, will allow: exemption of agricultural producers from VAT; receipt of direct subsidies and general government services; introduction of a fixed agricultural tax.

The proposed directions of institutional support have direct connection to all agrarian enterprises with different organizational and legal forms, which are functioning in the zone of irrigation. All this is possible only through well-formed institutions and creation of conditions for the efficient activity of the institutes by introducing legislative and regulatory support for the development of irrigated agriculture and agrarian sector, as well as the activity of the water-meliorative complex.

Traditions in the development of the agrarian sector of the economy, which historically have developed in the zone of insufficient humidification of Ukraine, should be preserved and protected by stable rules and norms of economic activity that have developed over many years, and the developed standards of the behavior of the society in this zone should be improved in the context of existing national legislation and the directions of its transformation with accordance to the requirements of EU countries.

In the process of the development of economic cooperation between Ukraine and the European Union, and preparation to fulfillment the 
obligations under the Association Agreement with the EU, an important prerequisite is the adaptation of Ukraine's economy to functioning according to European rules and principles of state support. Non-use of such support will put domestic enterprises on an unequal basis (compared to competitors from EU countries), and, in its turn, the modernization of the system of state support of economic entities is necessary in the context of the tasks of market economy development.

\section{CONCLUSIONS}

Irrigation is an important factor in ensuring food security in the zone of insufficient natural humidification. During the 60-70 years of the last century, a complicated and powerful water complex was built in Ukraine. The objectives of this complex were to provide the population with drinking water resources, water resources for the economy and utilities. The agrarian sector of the economy has always been a powerful water user. However, the transformation processes in the country's economy have affected not only land and water use, but also the activities of the water-meliorative complex.

The development of irrigated agriculture is closely connected with the efficiency of the water-meliorative complex of Southern region of Ukraine, so the question of restoration, effective use of existing irrigation potential and its further development has to be included into the priority tasks of development of the agrarian sector of the Ukrainian economy.

For the efficient development of both the water sector and irrigated agriculture, it is necessary to improve the system of institutional regulation and to create an appropriate institutional environment. Adaptation of the institutional approach to the system of irrigated agriculture includes the main institutions that ensure the rational use of nature and environmentallyfriendly development of the industry are: institutions of power, economy, ecology, law and society. In addition, correspondent institutions, which largely depend on the activities of the institutes, are important, and they provide efficient organizational and functional links within the institutions and limiting frameworks and rules of the game, based on formal laws and regulations. The next element of the environment is informal institutions, which include values, traditions, connected with the culture, education, mentality and mindset of the society.

\section{SUMMARY}

The article provides a proof that irrigation is one of the main ways of efficient sustainable agriculture in the South of Ukraine, especially in the conditions of regional climate changes. It diminishes dependence of the 
agrarian sector on the influence of natural and climatic factors, and provides for efficient agricultural activity in the conditions of lack of natural humidification. Irrigation favors for the decrease, or complete elimination of the deficit in water balance, the increase in yields of crops. Watermeliorative complex was built in Ukraine to support development of irrigated agriculture and to satisfy the needs in water resiurces.. The complex is one of the most powerful segments of economy and it is represented by a considerable number of water economy, meliorative, engineering objects, and corresponding infrastructure. However, transformations in the economy of the state and in the land use led to the corruption of the unity of meliorative systems, decrease in the irrigated areas, and deterioration of ecological and meliorative conditions of the lands. All these determines the necessity for reconstruction of water-meliorative complex through the modernization of meliorative systems and objects of water economy, and increase in the irrigated areas. An important economic factor that determines the necessity for the increase on the areas of irrigated lands is a need of the state in food products, production of which without irrigation in the conditions of insufficient natural humidification is impossible. An important role is played by institutional support of development both of the agrarian sector and sector of irrigation. Contradictions and conflicts, which occur due to the inefficient institutional support, restrain efficient innovative development of agricultural enterprises, including those in irrigated agriculture. It is proved that adaptation of institutional approach to the system of irrigated agriculture should include directions of formation of efficient institutional environment through the improvement of work of corresponding institutions and establishments. Proposed directions of institutional support are directly related to all agrarian enterprises with different organizational and legal forms, which are functioning in the zone of irrigation and allow increasing the efficiency of water economy activity on the irrigated lands in the South of Ukraine.

\section{REFERENCES}

1. Communication from the Commission to the European Parliament, the Council, the European Economic and Social - European Commission. Brussels, 16.4.2013.COM(2013)216final.11p. Retrieved from http://ec.europa.eu/ transparency/regdoc/rep/1/2013/EN/1-2013-216-EN-F1-1.Pdf.

2. Hadzieva V. Condition, problems and opportunities of irrigated agriculture after /Bulgarians to the European union-Rural Economics and Management, 2007. Vol. 52. C. 85-89. https://jcea.agr.hr/articles/774129_ 
Bulgarian_agriculture_in_the_conditions_of_the_EU_Common_Agricultural_ Policy_en.pdf.

3. Chandra A. Madramootoo. Water Management for Global Food Security/ McGill University, Macdonald Campus, 21,111 Lakeshore Road Ste. Anne de Bellevue QC H9X 3V9, Canada. (2011). 136 p. Retrieved from https://www.mcgill.ca/macdonald/GFS_Seminar_Cafiero

4. Концепція відновлення та розвитку зрошення в Південному регіоні України / за редакцією д.т.н., академіка НААН М.І. Ромащенка. К.: ЦП «Компринт», 2014. 30 с.

5. Коваленко П.І. Актуальні проблеми використання водних ресурсів і меліорованих земель на сучасному етапі. Міжвідомчий тематичний науковий збірник «Меліораиія і водне господарство». Київ, 2011. Вип. 99. C. 5-16.

6. Felix R. Reinders. Sustainable Micro Irrigation Principles and Practices / Edited by Megh R. Goyal, Vishal K. Chavan and Vinod K. Tripathi. Citation Information Principles and Management of Clogging in Micro Irrigation. Apple Academic Press, 2015. Pp. 21-30. https://www.crcpress.com/Sustainable-MicroIrrigation-Principles-and-Practices/Goyal/p/book/978177

7. Ромащенко М. І., Жовтоног О. І., Сагайдак Р. В., Книш В. В. Управління процесом відновлення та сталого використання. Меліорація $i$ водне господарство. Київ, 2014. Вип. 101. С. 137-147.

8. Zhovtonog O., Dirksen W., Roest K. Comparitive Assesment of Irrigation Sector Reform in Central and Eastern European Countries of transition. GTZ. 2003. Pp. 19-38.

9. Постанова Кабінету Міністрів «Про затвердження національного плану дій щодо боротьби з деградацією земель та опустелюванням. 2016. № 271-p.

10. Проект Стратегії розвитку зрошення та дренажу. Київ, 2017. 56 с.

11. Вожегова Р. А., Димов О. М., Грановська Л. М. Нормативи витрат матеріально-технічних ресурсів при вирощуванні основних сільськогосподарських культур: науково-методичне видання. Херсон: Грінь Д.С., 2014. 64 с.

12. Ромащенко М. І. Концептуальні засади відновлення зрошення у Південному регіоні України. Меліорація і водне господарство. Київ, 2013. Вип. 100. С. 7-17.

13. Ромащенко М. I. Наукові засади розвитку зрошення земель в Україні. К.: Аграрна освіта, 2012. 28 с.

14. Хвесик М. А., Голян В. А. Інституціональна модель природокористування в умовах глобальних викликів: монографія. К.: Кондор, 2007. $480 \mathrm{c}$. 
15. Закон України «Про меліорацію земель» від 19.10.2016 р. [Електронний ресурс]. Режим доступу: http://zakon3.rada.gov.ua/ laws/show/1389-14

16. Проект Закону України «Про внесення змін до деяких законодавчих актів України щодо вирішення питання колективної власності на землю» [Електронний ресурс]. Режим доступу: http://search.ligazakon.ua/__doc2.nsf/link1/JH4O11AA.html

17. Грановська Л. М., Жужа П. В. Екологічний аудит земель, що зрошуються в контексті їх сталого використання. Зрошуване землеробство: міжвід. темат. наук. зб. Херсон: Грінь Д.С., 2017. Вип. 67. C. 24-27.

18. D.North, R.P.Thomas. The Rise of the Western World: A New Economic History, Cambridge, Cambridge University Press. 1973. Pp. 101-105.

19. Дж. Норт. Институты, институциональные изменения и функционирование экономики. Перевод с английского А.Н. Нестеренко. Предисловие и научное редактирование Б.3. Мильнера. Фонд экономической книги «НАЧАЛА». МОСКВА, 1997. С. 17.

20. Фінансова політика в аграрному секторі економіки: стан та перспективи / За ред. проф. Д.І. Деми. Житомир: ЖНАЕУ, 2015. 364 с.

Information about the author: Hranovska L. M.,

Doctor of Economics Sciences, Professor,

Institute of Irrigated Agriculture of the National Academy of Agrarian Sciences of Ukraine Kherson, Naddniprianske, 73483, Ukraine 
DOI https://doi.org/10.36059/978-966-397-154-4/84-102

\title{
MODELING THE YIELD OF WINTER WHEAT AND CORN TAKING INTO ACCOUNT HYDROTHERMAL FACTORS IN THE CONDITIONS OF IRRIGATION OF THE SOUTH OF UKRAINE
}

\author{
Kokovikhin S. V.
}

\section{INTRODUCTION}

The main factors that determine the productivity of a plant organism are divided into three constituent groups: climatic - light, heat, water, gas composition of air; edaphysical - soil structure, its chemical composition; biological - a variety of microorganisms, plant and animal organisms, both useful and harmful. The certain plant species have a specific requirement for each of the factors of life, as well as the optimum their combination ${ }^{1}$.

The consideration of indicators of the crop production process is of a great importance in the directions of increasing the efficiency of the agricultural branch and the agrarian sector of the economy. The study of the impact of the PAR indexes on the yield level allows optimizing the action of agrotechnical factors and economic conditions in which agricultural production is carried out, as well as to increase the efficiency of organizational and economic activities of each enterprise. However, in recent years, there were almost no analytical studies on the evaluation of the PAR indexes influence on plant productivity, taking into account their impact on the yields, qualitative and other indexes ${ }^{2}$. In addition, the energy balance allows determining quantitative and qualitative changes in a comparison with past periods and levels; disclosing through the analysis the causes of dynamics and the factors that led to differences in the yield levels between zones, districts, groups of farms; assessment of the effectiveness of different factors on plant productivity; finding out unused reserves for the yields increase, etc. ${ }^{3}$.

Many experiments proved that $90-95 \%$ of a crop yield is formed by the receipt of solar energy and carbon dioxide of the atmosphere. In general

${ }^{1}$ Гойса Н. И., Олейник Р. Н., Рогаченко А. Д. Гидрометеорологический режим и продуктивность орошаемой кукурузы. Ленинград: Гидрометеоиздат, 1983. 230 с.

${ }_{2}^{2}$ Яблоков А. В. Популяционная биология. Москва: Высшая школа, 1987. 303 с.

${ }^{3}$ Григор'єв В. І. Водокористування в умовах недостатнього енергопостачання. Водне господарство Украӥни. Київ. 1997. № 1. С. 6-9. 
terms, all agrotechnical measures (irrigation, fertilization, soil tillage, etc.) should be directed to promote plants with the maximal use of solar energy and produce the highest amount of organic matter ${ }^{4}$.

One of the main tasks of the crop industry is to increase the coefficient of efficiency $(\mathrm{CE})$ of the use of solar energy $\left(\mathrm{k}_{\mathrm{Q}}\right)$, which reflects the ratio of the amount of the energy accumulated in the products of photosynthesis or was formed in biomass of a crop to the amount of the used radiation. According to the research of A. A. Nychyporovych, the maximum theoretically possible PAR efficiency per one molecule of $\mathrm{CO}_{2}$ absorption during photosynthesis requires the range of 8-10 quantum of sunlight ${ }^{5}$.

Current agricultural production uses only $0.7-2.0 \%$ of the PAR for the formation of yield. In this case, the coefficient of use of the PAR in normal production conditions is: winter wheat $-0.74-1.12 \%$, grain corn $-0.69-1.63$, green forage corn $-1.23-1.47$, sugar beet $-1.34-1.84 \%$, respectively. According to the researches, the average value of the PAR use is: in normal production conditions $-0.5-1.5 \%$, in favorable $-1.0-3.0 \%$, at the maximum optimization of cultivation conditions - 3.5-5.0\%, and theoretically possible $-6.0-8.0 \%^{6}$. Consequently, the use of the PAR by plants is an integral indicator of the impact of all other factors on the productivity of a crop, as any yield increase leads to an increase in its use ${ }^{7}$.

At the same time, along with the intensity of solar radiation, plant productivity is significantly affected by the temperature of air and soil. The impact of thermal factors on the growth and development of crops has a versatile character: thermal factors in the form of temperature serve as indicator of energy conditions; the level of thermal regime is determined by the intensity of biochemical processes in a plant organism, which affects the speed of growth and development of plants. The requirements of plants for heat at this point of view is divided into three gradations: biological minimum temperature ( $\mathrm{min}$ ), if lower than plants stop vegetation; temperature optimum (opt), the greatest productivity of the photosynthetic activity of plants is provided; biological

4 Григоров М. С. Водосберегающие технологии выращивания с.-г. культур. Волгоград: ВГСХА, 2001. 169 с.

${ }^{5}$ Ничипорович А. А. Энергетическая эффективность и продуктивность фотосинтезирующих систем как интегральная проблема. Физиология растений. 1978. Т. 25. Вып. 5. C. $922-937$.

${ }^{6}$ Ничипорович А. А. Фотосинтетическая деятельность растений в посевах. Москва: Издательство АН СССР, 1961. 133 с.

7 Лисогоров К.С., Писаренко В.А. Наукові основи використання зрошуваних земель у степовому регіоні на засадах інтегрального управління природними і технологічними процесами. Таврійський науковий вісник. 2007. Вип. 49. С 49-52. 
maximum temperature $(\max )$ - plants stop biochemical processes due to overheating, and if higher they $\mathrm{die}^{8}$.

\section{Winter wheat productivity depending on hydrothermal indicators}

Winter wheat is one of the most important crops of modern agriculture. It is one of the most important constituent elements of the world market of agricultural products, the basis of Ukraine's food security. World economic crisis adversely affected the development of grain farming and, in particular, the production of wheat, which significantly affected the export opportunities of the state. Trends in recent years show that by the present time the problems of ensuring sustainability of grain production, the satisfaction of national demand in the high-quality food grain, the insurance of a high level of the industry competitiveness and profitability have not been solved ${ }^{9}$.

There are a number of difficulties occurring at the implementation of forecasts, which are arisen both due to the natural and economic factors. The first are manifested in the high amplitude of fluctuations and unpredictability of weather conditions, which significantly affect the level of yield, even at a high level of agrotechnology. The second negative factors of plant productivity prediction are explained by the presence in Ukraine, as well as in many other countries, of agricultural enterprises of different sizes and specialization (small farmers, large-scale commercial farms, state farms, farmers with partial specialization in agriculture, etc.), which have very different technological and economic opportunities of the systems for information collection, database processing, access to the Internet, etc. ${ }^{10}$.

However, the efficiency of irrigation regimes depends significantly on the peculiarities of the current meteorological conditions, which determines the need for adjusting artificial humidification considering these factors through the forecasting and modeling of the conditions of agrocenosis and plants productivity.

8 Розробка грунтозахисних ресурсо- та енергозберігаючих систем ведення сільськогосподарського виробництва 3 використанням комп’ютерного програмного комплексу: метод. реком. / розроб. Ю. О. Тараріко; УААН, Ін-т агроекології та біотехнології. Київ: Нора-Друк, 2002. 122 с.

${ }_{9}^{9}$ Меліоровані агроекосистеми. Оцінка та раціональне використання агроресурсного потенціалу України. Зони зрошення і осушення: [колект. монографія] / за ред. акад. HАAМ М. І. Ромащенка, чл.-кор. НААН Ю. О. Тараріко ; Нац. акад. аграр. наук України, Ін-т вод. проблем і меліорації. Київ; Ніжин: Лисенко М. М., 2017. 695 с.

10 Писаренко В.А., Мішукова Л.С., Коковіхін С.В., Присяжний Ю.І. Ефективність різних схем режимів зрошення пшениці озимої в умовах південного Степу України. Зрошуване землеробство. 2008. Вип. 50. С. 31-37. 
The aim of the study was to determine the influence of agrometeorological factors on the productivity of winter wheat under the conditions of use of biologically optimal irrigation regime using variational, correlation-regression and index analysis. of perennial experimental data.

The input materials for modeling and forecasting were the experimental data of the field experiments with winter wheat conducted at the Institute of Irrigated Agriculture of NAAS for the period of 1970-2018. Agrotechnology used in the study was common for the irrigated zone of southern Ukraine. To establish statistical models and perform index analysis the indicators of Kherson agrometeorological station located nearby the experimental field of the Institute were used. The study on this direction was conducted using special methodology for the use of information technologies in agriculture ${ }^{11}$.

Generalization of long-term thermal air regime testifies about a steady trend of annual increase in positive temperatures over the last 48 years.

According to the temperature regime, the difference between the amplitude of fluctuations is set in temperatures of ten-twenty-year periods, especially in terms of the sums above $10^{\circ} \mathrm{C}$. Thus, the period from 1970 to 1985 years was characterized by significant fluctuations, which averaged to $57-349^{\circ} \mathrm{C}$, and the period from 1990 to 2000 years differed by stability with deviations from the average level of only $12.3-72.8^{\circ} \mathrm{C}$. Since 2000 till nowadays it has also been observed the increase in the amplitude of deviation of the temperatures above 5 and $10^{\circ} \mathrm{C}$, which is similar to the trend for 1970-1985.

Analysis of the obtained data on the sum of atmospheric precipitation during the vegetative period of winter wheat testifies about a decrease in their amounts during the studied period and for the predicted until 2020 period.

Our calculations proved that the process of gradual aridization and the reduction of humidity coefficient is taking place in southern sub-zone of the Steppe zone of Ukraine.

On average for the studied period, the $\mathrm{HC}$ for the vegetation of winter wheat was 0.61 with the range of the confidence interval from 0.505 to 0.695. In addition, as it is depicted in the figure, $\mathrm{HC}$ has a very large discrepancy by the individual years (the coefficient of variation in the investigated period is $49.7 \%$ ). Prediction by the linear regression equation indicates reduction of the humidity coefficient in 2010 to 0.39 , and in 2015 to 0.35 , respectively.

11 Лавриненко Ю.О. Наукове обгрунтування технології вирощування кукурудзи при краплинному способі поливу: Монографія / Ю.О. Лавриненко, В.Б. Рубан, В.Б. Михайленко. Херсон: Айлант, 2014. 198 с. 
According to the settled tasks, we conducted the collection, systematization and synthesis of experimental data of the field and laboratory experiments, which were conducted in the zone of irrigation of the South of Ukraine on southern chernozems and dark-chestnut middleloamy soil under the deep level of groundwater by the laboratories of irrigation, agrochemistry and meliorative soil science, as well as in other scientific divisions of the Institute of Irrigated Agriculture of NAAS ${ }^{12}$.

According to the results of the mathematical modelling, the correlationregression relations between the productivity of winter wheat and amounts of precipitation, individually or in the sum with the irrigation norm, were determined. In addition, the patterns of the influence on yields, differentiation of nitrogen and phosphoric fertilizers doses were determined. All the obtained mathematical models are characterized by the moderate and high degree of closeness of relations with the fluctuations of the correlation coefficients (R) from 0.6740 to 0.9345 .

According to the reports of the laboratory of irrigation of the Institute of Irrigated Agriculture of NAAS, it was accumulated the information on the dynamics of winter wheat yields during the period of 1971-2018, with taking into account the pre-sowing and vegetation watering that were carried out using the water of the Ingulets irrigation system.

Dependence of the level of agrometeorological conditions of the vegetation period was defined as the ratio of the actual crop level of a certain year to its trend value by the formula $(1.1)^{13}$.

$$
\mathrm{I}=\mathrm{Y}_{\text {fact }} / \mathrm{Y}_{\text {trend }} \text {, }
$$

Where I - Index of evaluation of agrometeorological conditions of vegetative

period;

$\mathrm{Y}_{\text {fact }}-$ actual yields, $\mathrm{t} / \mathrm{ha}$;

$\mathrm{Y}_{\text {trend }}$ - annual yield by a trend, $\mathrm{t} / \mathrm{ha}$, which is

calculated by the mathematical equation of linear

regression for the zone of Southern Steppe of Ukraine (formula (1.2):

Where $\mathrm{X}$ - years.

$$
\mathrm{y}=-0,527 x+1104
$$

Through the calculations by the specified methodology, it was proved that the level of agrometeorological favorable conditions for the winter

12 Ушкаренко В. О., Нікішенко В. Л., Голобородько С. П., Коковіхін С. В. Дисперсійний і кореляційний аналіз результатів польових дослідів: монографія. Херсон: Айлант, 2009. 372 с.

${ }_{13}$ Можаев Н. И., Серикпаев Н. А., Стыбаев Г. Ж. Программирование урожаев сельскохозяйственных культур: учебное пособие. Астана: Высшее образование, 2013. $158 \mathrm{c}$. 
wheat yield fluctuates during the studied period from 0.42 to 1.36 with the average perennial value of 0.98 .

A large interval of fluctuations in the level of agrometeorological conditions, expressed by the index, was caused by significant fluctuations in individual meteorological indexes.

Theoretically justified plant requirements to the environment gave the opportunity to use the inertial method to simulate the impact of agrometeorological conditions on the formation of winter wheat yields during the vegetation period.

The model for estimation of the index of the favorable agrometeorological conditions during spring-summer vegetation of winter wheat consists of the complex of equations of second order multiple regression (formula (1.3):

$$
I_{n}=Z_{n}+a_{n} T_{n}+b_{n} T_{n}^{2}+c_{n} R_{n}+d_{n} R_{n}{ }^{2}+e_{n} T_{n} R_{n}
$$

where $\mathrm{n}$ is the sequence number of the month from 3-7, each year.

$\mathrm{Z}_{\mathrm{n}}$ - independent argument;

$a_{n}, b_{n}, c_{n}, d_{n}, e_{n}-$ model coefficients calculated through the regression of the surface response per month;

$\mathrm{T}_{\mathrm{n}}$ - average monthly air temperature per month, ${ }^{\circ} \mathrm{C}$;

$\mathrm{R}_{\mathrm{n}}$ - month sum of precipitation by months of vegetation, $\mathrm{mm}$;

We calculate the annual index of agrometeorological conditions as the sum of the influences of each individual month with the corresponding coefficients. And then we determine the projected yield levels by the formula (1.4):

Where $Y_{\text {pr }}$ - the predicted yield, $t / h a$;

$$
\mathrm{Y}_{\mathrm{pr}}=\mathrm{I} \times \mathrm{Y}_{\text {trend }} \text {, }
$$

I - index of evaluation of agrometeorological conditions of vegetation period;

$\mathrm{Y}_{\text {trend }}$ - annual yield by a trend, $\mathrm{t} / \mathrm{ha}$

The mathematical model obtained allows getting indexes, which are close to the actual ones, however, as we can see, it looks somewhat smoothed (Fig. 1).

The accuracy of the predictive models greatly depends on the stability of the weather conditions, therefore, it was determined that for the zone of the risky agriculture, to which the South of Ukraine belongs, at the expense of unstable and insufficient humidification, a large amplitude of daily temperatures, the models provided slightly less values of grain productivity for wheat. These features of the developed models require the expansion of the number of ascending indexes in the selection of the most important factors influencing the yield during the vegetation period of the studied crop. 


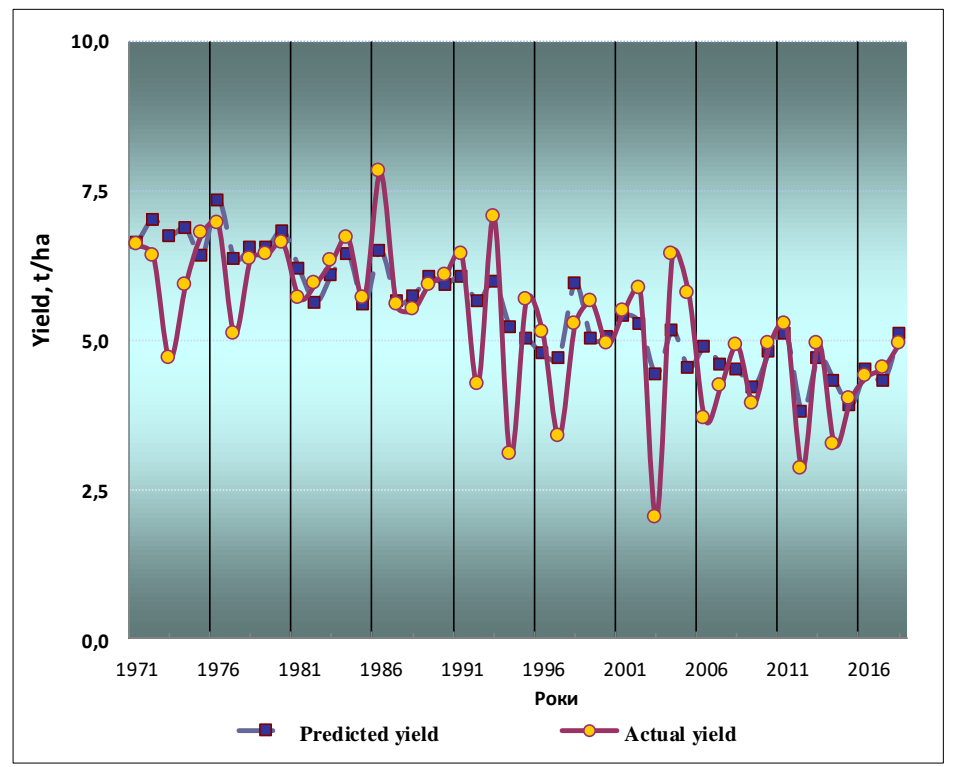

Fig. 1. Actual and predicted (modeled) yields of winter wheat under the optimum irrigation regime

\section{Identification of the patterns of productivity processes in corn plants depending on the thermal energy conditions in the conditions of the South of Ukraine}

The relationship of the heat supply for agrocenosis on the dynamics of solar radiation is proved experimentally. Taking into account that these factors are provided in sufficient quantity for the major crops of Southern Steppe of Ukraine, there is a need for their maximal usage by the means of adjustment of elements of cultivation technologies. It should be remembered that according to the law of interaction of factors, the potential of solar radiation and thermal regime is used more fully if plants are better supplied with other factors and, first of all, with water and nutrients. The degree of use of the PAR and thermal resources strongly depends on the cultivation conditions of a crop.

The comparison of the duration of the vegetation period and the sum of biologically active temperatures above $10^{\circ} \mathrm{C}$ and excluding temperatures below $10^{\circ} \mathrm{C}$ revealed a clear correlation dependence between these indexes.

The obtained statistical models allow to carry out the calculations of the duration of vegetation period based on the actual indexes of the sum of 
biologically active temperatures with the help of the developed linear regression equations. We must note that the greatest impact on the vegetation period have the temperatures above $10^{\circ} \mathrm{C}$ that was confirmed by the developed correlation-regression models.

In the United States and Canada, the systems of classifying the terms of ripeness of different hybrids of corn by the units of heat accumulation are accepted: in the U.S. by the index of the HU (Heat Units); In Canada-CHU (Crop Heat Units). A Canadian system of determining the ripeness of corn has a certain scientific and practical interest for the South of Ukraine, because it was developed by the climatologist Andre Butzman. The investigations of this scientist proved that climatic factors for Canada and Ukraine are almost identical, therefore the system of Crop Heat Units can be used for local determination of ripeness of corn. This system is also suitable for soybean ${ }^{14}$.

The results of our studies allowed to identify the significant amplitude in fluctuations in the level of corn yield by some years, its increase in moderately humid and wet years and a significant decrease in the moderately dry and dry. And the smallest fluctuations in the yield were fixed in the middle-ripening hybrids, and the highest - in the early-ripening ones.

Systematization and grouping of perennial agrometeorological indicators, total water consumption and irrigation regime during the growing season of grain corn indicate that they are changing in a very wide range depending on the hydrothermal conditions of the vegetation period.

Statistical analysis determined a very high difference in variability of both meteorological and agronomic indexes. Thus, the sum of air temperature above $5^{\circ} \mathrm{C}$ for the studied period was characterized by the minimum range of variation ( $V$ was only $7.4 \%$ ) at the confidence interval from 1900 to $1999^{\circ} \mathrm{C}$.

The variability of the sum of effective temperatures above $10^{\circ} \mathrm{C}$ slightly increased - the coefficient of variation increased to $11.2 \%$ at the average perennial value of this index of $1302 \pm 23.3^{\circ} \mathrm{C}$. In regard to the income of precipitation, a very high degree of variation ( $V$ is $34.7 \%$ at the confidence range of $1730-2198 \mathrm{~m}^{3} / \mathrm{ha}$ ) was determined. This indicates a significant irregularity of natural humidification and substantiates the use of irrigation in the conditions of Southern Steppe of Ukraine.

Significant variability in atmospheric precipitation income caused a significant variation $(25.2 \%)$ in the volumes of irrigation norms, which equaled, on average for $1970-2018$, to $1924 \pm 77.7 \mathrm{~m}^{3} /$ ha. However, taking

${ }^{14}$ Андриевский С. Как выбрать гибрид кукурузы и сэкономить при этом немалые деньги. Зерно. 2006. № 4. С. 36-39. 
into account the interconnected effect of precipitation and irrigation norms on the total water consumption, this index was characterized by the moderate degree of variability (11.5\%) in the confidence interval of $4275-4627 \mathrm{~m}^{3} / \mathrm{ha}$.

Yield of grain corn, according to the analysis of the long-term dataset, fluctuated from $3.83 \mathrm{t} / \mathrm{ha}$ (in the severely arid 1996) to $13.4 \mathrm{t} / \mathrm{ha}$ (in the humid 1981) at the average value of $8.49 \pm 0.31 \mathrm{t} / \mathrm{ha}$. The variation analysis proved a high degree of variability $(V=23.0 \%)$ of the productivity indexes of corn under the influence of meteorological factors, even under the use of optimal irrigation regime, justifying the need to improve the cultivation technology at irrigated lands in order to increase the adaptability of hybrids to the irregular precipitation and changes in thermal regime.

Multifactoral experiments, conducted in different soil and climatic zones, allowed to establish an index link between the crop productivity and meteorological parameters. The assessment of the level of agrometeorological favorable conditions of the growing period for certain types of crops, including grain corn, is defined as the ratio of an actual level of yield of an individual year to its trend value.

Our estimates determined that under the optimum regime of irrigation, the level of agrometeorological favorable conditions for the growth and development of grain corn fluctuates during the period of 1970-2008 from 0.42 to 1.49 , at the average perennial value of 1.0 (Fig. 2).

Significant fluctuations in the index of agrometeorological conditions assessment are caused by the yearly fluctuations of individual meteorological indexes. Statistical modeling shows that the most favorable weather conditions were in the periods of 1980-1983, 1991-1993, 1997 and 2004. In the specified years, there was observed an increased precipitation and moderate thermal regime.

On the contrary, in 1994-1996, 1998-1999 and 2006-2007 we discovered a critical decrease in the productivity of corn due to the extremely high air temperatures, severe deficit of natural humidification, dry winds, etc. In recent years (2014-2018), due to favorable weather conditions - corn productivity - rises.

Statistical analysis of meteorological data for individual months for the period of 1970-2008 indicates that as on the whole for a year, the temperature regime is marked with stability ( $V$ ranges from 3.0 to $4.8 \%$ ), and precipitation - with a significant variation (Table 1 ). The highest variability (the coefficient of variation - 42.9\%) was observed in the precipitation income in August, from 0 to $120.2 \mathrm{~mm}$, which indicates the need for careful observance of irrigation regime during this period. Using the index method, 
it is possible to simulate the influence of agrometeorological conditions on the formation of corn crop during the growing season.

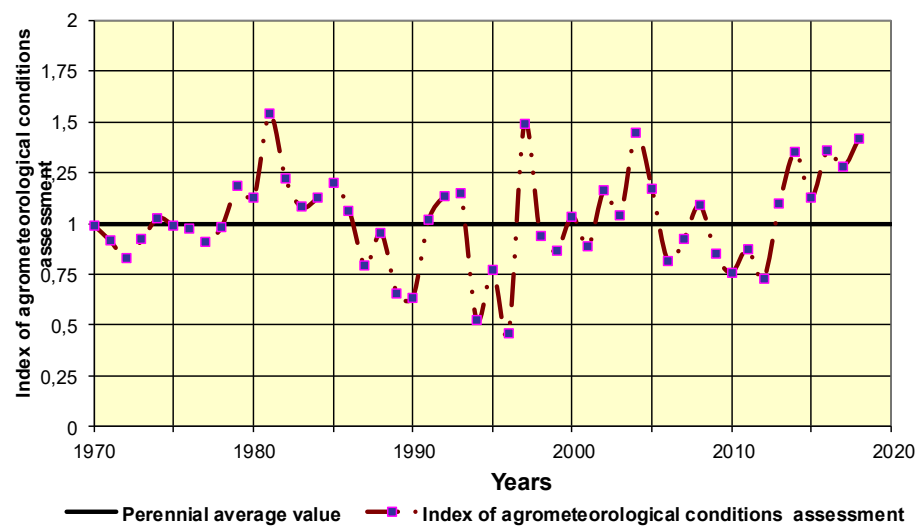

Fig. 2. The index of agrometeorological vegetation conditions assessment for Grain corn

Table 1

Statistical characteristics of average monthly air temperature and monthly precipitation during the growing season of grain corn (the average for 1970-2018)

\begin{tabular}{|c|c|c|c|c|c|c|}
\hline \multirow{3}{*}{ Months } & \multicolumn{6}{|c|}{ Indexes } \\
\cline { 2 - 7 } & \multicolumn{3}{|c|}{ Temperature } & \multicolumn{3}{c|}{ Precipitation } \\
\cline { 2 - 7 } & $\begin{array}{c}\text { Min, } \\
{ }^{\circ} \mathbf{C}\end{array}$ & $\begin{array}{c}\text { Max } \\
{ }^{\circ} \mathbf{C}\end{array}$ & $\begin{array}{c}\text { Factor } \\
\text { Variations } \\
(\boldsymbol{V}), \boldsymbol{\%}\end{array}$ & $\begin{array}{c}\text { Min, } \\
\mathbf{~ m m}\end{array}$ & $\begin{array}{c}\text { Max, } \\
\mathbf{M M}\end{array}$ & $\begin{array}{c}\text { Factor } \\
\text { Variations }(\boldsymbol{V}), \\
\mathbf{\%}\end{array}$ \\
\hline May & 13.42 & 19.47 & 3.9 & 6.3 & 143.3 & 22.0 \\
\hline June & 18.21 & 23.66 & 4.8 & 4.1 & 99.5 & 17.5 \\
\hline July & 19.93 & 26.63 & 3.0 & 1.0 & 138.9 & 26.7 \\
\hline August & 18.46 & 25.51 & 3.9 & 0 & 120.2 & 42.9 \\
\hline September & 13.51 & 20.75 & 3.7 & 0.8 & 120.2 & 33.5 \\
\hline
\end{tabular}

At the same time, it is necessary to calculate the index of favorability of agrometeorological conditions during the entire growing season, which is based on the evaluation of the indexes of each month by defining the regression coefficients of their impact on corn grain yields. The statistical model of the estimation of the index of agrometeorological conditions for 
the growing season of grain corn consists of the complex of equations of the multiple regression:

$$
\begin{aligned}
& \mathrm{I}_{5}=\mathrm{Z}_{5}+\mathrm{a}_{5} \mathrm{~T}_{5}+\mathrm{b}_{5} \mathrm{~T}_{5}{ }^{2}+\mathrm{c}_{5} \mathrm{R}_{5}+\mathrm{d}_{5} \mathrm{R}_{5}{ }^{2}+\mathrm{e}_{5} \mathrm{~T}_{5} \mathrm{R}_{5} ; \\
& \mathrm{I}_{6}=\mathrm{Z}_{6}+\mathrm{a}_{6} \mathrm{~T}_{6}+\mathrm{b}_{6} \mathrm{~T}_{6}{ }^{2}+\mathrm{c}_{6} \mathrm{R}_{6}+\mathrm{d}_{6} \mathrm{R}_{6}{ }^{2}+\mathrm{e}_{6} \mathrm{~T}_{6} \mathrm{R}_{6} ; \\
& \mathrm{I}_{7}=\mathrm{Z}_{7}+\mathrm{a}_{7} \mathrm{~T}_{7}+\mathrm{b}_{7} \mathrm{~T}_{7}{ }^{2}+\mathrm{c}_{7} \mathrm{R}_{7}+\mathrm{d}_{7} \mathrm{R}_{7}{ }^{2}+\mathrm{e}_{7} \mathrm{~T}_{7} \mathrm{R}_{7} ; \\
& \mathrm{I}_{8}=\mathrm{Z}_{8}+\mathrm{a}_{8} \mathrm{~T}_{8}+\mathrm{b}_{8} \mathrm{~T}_{8}{ }^{2}+\mathrm{c}_{8} \mathrm{R}_{8}+\mathrm{d}_{8} \mathrm{R}_{8}{ }^{2}+\mathrm{e}_{8} \mathrm{~T}_{8} \mathrm{R}_{8} ; \\
& \mathrm{I}_{9}=\mathrm{Z}_{9}+\mathrm{a}_{9} \mathrm{~T}_{9}+\mathrm{b}_{9} \mathrm{~T}_{9}{ }^{2}+\mathrm{c}_{9} \mathrm{R}_{9}+\mathrm{d}_{9} \mathrm{R}_{9}{ }^{2}+\mathrm{e}_{9} \mathrm{~T}_{9} \mathrm{R}_{9},
\end{aligned}
$$

where $\mathrm{I}_{5-} \mathrm{I}_{9}-$ indexes of the evaluation of agrometeorological conditions during

grain corn cultivation, (5-7 sequential number of the month);

$\mathrm{Z}_{5} \mathrm{Z}_{9}$ - independent argument of the equation;

$\mathrm{a}_{5-} \mathrm{a}_{9}, \mathrm{~b}_{5}-\mathrm{b}_{9}, \mathrm{c}_{5}-\mathrm{c}_{9}, \mathrm{~d}_{5}-\mathrm{d}_{9}, \mathrm{e}_{5}-\mathrm{e}_{9}-$ model coefficients;

$\mathrm{T}_{5}-\mathrm{T}_{9}-$ average monthly air temperature, ${ }^{\circ} \mathrm{C}$ by the months of the vegetation;

$\mathrm{R}_{5}-\mathrm{R}_{9}-$ monthly amount of precipitation by the months of the vegetation, $\mathrm{mm}$

To assess the index of the favorability of agrometeorological conditions of the growing season of grain corn on the whole during the vegetation period, you can use the sum of the effect of each individual month with the relevant coefficients of the influence. In addition, the calculated indexes of agrometeorological conditions of the vegetation of grain corn can be used to forecast yields using the actual parameters of the average daily air temperature and precipitation.

The results of our calculations of the projected yield of grain corn and comparison of it with the actual productivity of the plants testify to nonsignificant errors $( \pm 2.2-3.7 \%)$ and the possibility of using the abovementioned method for setting the grain yield level in both scientific and production purposes.

The highest consumption of thermal resources per ton of corn $\left(T_{u}=677.8\right)$ were in dry 2002 year in the late-ripening hybrids, and in this variant the minimum efficiency of the PAR use $\left(\eta_{f}=0.87 \%\right)$ was fixed. This is explained by very unfavorable weather conditions of this year (high temperature and low relative humidity of air) during the grain filling stage of hybrids of the late-ripening group. The most optimal use of thermal resources $\left(T_{u}=201.6\right)$ and the income of photosynthetic active radiation $\left(\eta_{f}=3.20 \%\right)$ was observed in the late-ripening hybrids in moderately-dry 2006 year. 
The generalization of the obtained fifteen-year results of the field experiments in the blocks of years by the natural humidification and ripeness groups allowed to identify the difference in the dynamics of yielding data of corn in the direction of its sustainable growth from dry years to humid ones (Table 2).

The highest yield (10.3-12.6 t/ha) of the hybrids of all the ripeness groups was formed in humid years, and the lowest (5.9-7.0 t/ha) - in dry ones. The same tendencies were found in the estimation of the temperature index indicators and the coefficient of the efficiency of the PAR use.

On average for the years of the study, it was established that the heat energy factors are used best by the early and middle-ripening hybrids, which have indicators of temperature index of 304.1 and 305.1, and the coefficient of efficiency of the PAR use $-2.15 \%$. In the late-ripening hybrids, the increase of $T_{u}$ by 5.1 and $5.4 \%$ was observed under the decrease in $\eta_{f}$ by $2.4 \%$, respectively.

Variation and correlation analysis allowed to define the different by force and direction interactions between the yield of corn and the main heat energy factors (Table 3). Variation analysis of the yielding data showed their stability in humid, moderate and moderately humid years, since the variation factor fluctuates within 9.2-10.4\%. However, in the moderately-dry and dry years there has been an increase in productivity indexes of corn grain in 2.52.9 times ( $V$ was 25.8 and $26.6 \%$ ).

The evaluation of the variation of thermal resources proved the stability of the sum of temperature during the vegetation period, but also significant difference in the temperature index, which in humid years has low variability $(V=5.1 \%)$, medium $(V=18.6$ and $12.4 \%)$ - in moderately humid and moderate years, significant $(V=23.2$ and $33.5 \%)$ - in moderately-dry and dry years. This phenomenon indicates a positive effect of the increased air temperature in humid years on the intensity of production processes of the plants. 
Table 2

Grain yield of different by the ripening groups corn hybrids depending on the natural humidification and thermal energy indexes

\begin{tabular}{|c|c|c|c|c|c|c|c|c|}
\hline \multirow{2}{*}{$\begin{array}{l}\text { Humidification } \\
\text { conditions by } \\
\text { the years }\end{array}$} & \multirow{2}{*}{$\begin{array}{c}\text { Group } \\
\text { ripeness } \\
\text { Hybrids }\end{array}$} & \multicolumn{7}{|c|}{ Indexes } \\
\hline & & $\begin{array}{c}\bar{x}, \\
\text { t/ha }\end{array}$ & $\Sigma T,{ }^{\circ} \mathbf{C}$ & $T_{u}$ & $\begin{array}{c}E_{v}, \\
\text { GJ/ha }\end{array}$ & $\begin{array}{c}Q, \\
\text { GJ/ha }\end{array}$ & $\underset{\mathbf{G J} / \mathbf{h a}}{Q_{F}}$ & $\begin{array}{l}\eta_{f}, \\
\%\end{array}$ \\
\hline \multirow{3}{*}{ Humid } & $\begin{array}{c}\text { Early } \\
\text { ripening }\end{array}$ & 10.3 & $2,318.1$ & 226.4 & 330.1 & 22,245 & 11,345 & 2.91 \\
\hline & $\begin{array}{c}\text { Middle } \\
\text { ripening }\end{array}$ & 11.5 & $2,697.4$ & 234.9 & 370.4 & 26,889 & 13,714 & 2.72 \\
\hline & $\begin{array}{l}\text { Late } \\
\text { riping }\end{array}$ & 12.6 & $2,914.7$ & 232.6 & 403.9 & 29,630 & 15,112 & 2.68 \\
\hline \multirow{3}{*}{$\begin{array}{l}\text { Moderately } \\
\text { humid }\end{array}$} & $\begin{array}{c}\text { Early } \\
\text { ripening }\end{array}$ & 7.7 & $2,292.5$ & 302.6 & 248.9 & 24,590 & 12,541 & 2.08 \\
\hline & $\begin{array}{c}\text { Middle } \\
\text { ripening }\end{array}$ & 9.1 & $2,586.6$ & 291.6 & 293.6 & 27,541 & 14,045 & 2.19 \\
\hline & $\begin{array}{l}\text { Late } \\
\text { riping }\end{array}$ & 10.6 & $2,956.9$ & 285.2 & 342.9 & 31,847 & 16,242 & 2.20 \\
\hline \multirow{3}{*}{ Moderate } & $\begin{array}{c}\text { Early } \\
\text { ripening }\end{array}$ & 7.4 & $2,156.3$ & 293.9 & 239.7 & 21,897 & 11,168 & 2.15 \\
\hline & $\begin{array}{c}\text { Middle } \\
\text { ripening }\end{array}$ & 8.0 & $2,509.4$ & 317.2 & 256.2 & 25,115 & 12,809 & 2.00 \\
\hline & $\begin{array}{l}\text { Late } \\
\text { riping }\end{array}$ & 8.1 & $2,839.5$ & 351.8 & 261.1 & 29,141 & 14,862 & 1.76 \\
\hline \multirow{3}{*}{ Moderately dry } & $\begin{array}{c}\text { Early } \\
\text { ripening }\end{array}$ & 7.4 & $2,092.0$ & 296.2 & 237.0 & 21,222 & 10,824 & 2.21 \\
\hline & $\begin{array}{c}\text { Middle } \\
\text { ripening }\end{array}$ & 8.7 & $2,416.1$ & 293.8 & 280.4 & 24,506 & 12,498 & 2.27 \\
\hline & $\begin{array}{l}\text { Late } \\
\text { riping }\end{array}$ & 10.1 & $2,706.9$ & 281.4 & 324.1 & 27,169 & 13,857 & 2.37 \\
\hline \multirow{3}{*}{ Dry } & $\begin{array}{c}\text { Early } \\
\text { ripening }\end{array}$ & 5.9 & $2,124.9$ & 378.2 & 190.9 & 22,732 & 11,593 & 1.65 \\
\hline & $\begin{array}{c}\text { Middle } \\
\text { ripening }\end{array}$ & 7.0 & $2,474.3$ & 368.2 & 225.4 & 25,785 & 13,150 & 1.73 \\
\hline & $\begin{array}{c}\text { Late } \\
\text { riping }\end{array}$ & 7.0 & $2,759.5$ & 441.0 & 226.9 & 28,554 & 14,563 & 1.58 \\
\hline \multirow{3}{*}{$\begin{array}{l}\text { Average for the } \\
\text { years of the } \\
\text { study }\end{array}$} & $\begin{array}{c}\text { Early } \\
\text { ripening }\end{array}$ & 7.5 & $2,181.7$ & 304.1 & 243.1 & 22,469 & 11,459 & 2.15 \\
\hline & $\begin{array}{c}\text { Middle } \\
\text { ripening }\end{array}$ & 8.7 & $2,518.0$ & 305.1 & 279.2 & 25,808 & 13,162 & 2.15 \\
\hline & $\begin{array}{l}\text { Late } \\
\text { riping }\end{array}$ & 9.5 & $2,821.6$ & 321.6 & 306.5 & 29,104 & 14,843 & 2.10 \\
\hline
\end{tabular}


Table 3

Results of statistical analysis of variability and interrelations between the heat energy factors and the yield of grain corn

\begin{tabular}{|c|c|c|c|c|c|c|}
\hline \multirow{2}{*}{$\begin{array}{c}\text { Humidification } \\
\text { conditions by the } \\
\text { years }\end{array}$} & \multirow[b]{2}{*}{ Coefficients } & \multicolumn{5}{|c|}{ Indexes } \\
\hline & & $\begin{array}{l}\bar{x}, \\
\text { t/ha }\end{array}$ & $\begin{array}{c}\Sigma T, \\
{ }^{\circ} \mathrm{C}\end{array}$ & $T_{u}$ & $\underset{\text { GJ/ha }}{Q_{f},}$ & $\begin{array}{l}\boldsymbol{\eta}_{f} \\
\%\end{array}$ \\
\hline \multirow{3}{*}{ Humid } & Variation, $V, \%$ & 9.2 & 11.4 & 5.1 & 13.5 & 6.5 \\
\hline & Correlation, $R$ & - & 0.90 & 0.23 & 0.91 & 0.49 \\
\hline & $\begin{array}{c}\text { Determination, } \\
R^{2}\end{array}$ & - & 0.81 & 0.05 & 0.82 & 0.24 \\
\hline \multirow{3}{*}{ Moderately humid } & Variation, $V, \%$ & 10.4 & 12.4 & 18.6 & 19.7 & 31.6 \\
\hline & Correlation, $R$ & - & 0.31 & -0.80 & -0.17 & 0.77 \\
\hline & $\begin{array}{c}\text { Determination, } \\
R^{2}\end{array}$ & - & 0.10 & 0.64 & 0.03 & 0.59 \\
\hline \multirow{3}{*}{ Moderate } & Variation, $V, \%$ & 9.2 & 12.3 & 12.4 & 12.6 & 12.8 \\
\hline & Correlation, $R$ & - & 0.36 & -0.41 & 0.34 & 0.40 \\
\hline & $\begin{array}{c}\text { Determination, } \\
R^{2}\end{array}$ & - & 0.13 & 0.17 & 0.11 & 0.16 \\
\hline \multirow{3}{*}{ Moderately dry } & Variation, $V, \%$ & 25.8 & 11.7 & 23.2 & 11.5 & 26.2 \\
\hline & Correlation, $R$ & - & 0.41 & -0.89 & 0.16 & 0.90 \\
\hline & $\begin{array}{c}\text { Determination, } \\
R^{2} \\
\end{array}$ & - & 0.17 & 0.78 & 0.03 & 0.81 \\
\hline \multirow{3}{*}{ Dry } & Variation, $V, \%$ & 26.6 & 12.1 & 33.5 & 11.2 & 26.7 \\
\hline & Correlation, $R$ & - & 0.20 & -0.86 & 0.03 & 0.92 \\
\hline & $\begin{array}{c}\text { Determination, } \\
R^{2}\end{array}$ & - & 0.04 & 0.73 & 0.00 & 0.85 \\
\hline
\end{tabular}

The indexes of the income of photosynthetic-active radiation $\left(Q_{F}\right)$ had an average variability with the variation degrees ranging from 11.2 to $19.7 \%$. The highest efficiency of the PAR use was observed in the humid years $(V=6.5 \%)$, medium level $(V=12.8 \%)$ - in moderate ones, while in other was distinguished by a high degree of variability $(V=26.2-31.6 \%)$.

Interesting results showed a correlation analysis of the natural heat supply indexes. In the humid years, a very high degree of connection between the air temperature and the yield of corn was determined with the correlation coefficient of 0.90 and the determination of the crop level by $81 \%$, which is due to a limiting effect of air temperature under the high water supply. There is a decrease in the degree of relations in 2.2-4.5 times in other by the evaporation deficit years.

Similar dependencies of corn productivity were determined in regard to the index of photosynthetic-active radiation, because only in the humid years there was a high degree of connection $(R=0.91)$ at $81 \%$ level of the influence on the grain yield of the studied crop. In other years, there was a weak positive and negative connection between these indexes at correlation 
coefficients from -0.17 to 0.34 , and in dry years - the connection was almost absent $(R=0.03)$. It should be noted that the increase in the efficiency of the PAR use positively affected the grain yield in all the years of the study, but the highest degree of the connections was determined in moderately-dry $(r=0.90)$ and dry $(r=0.92)$ years, when the effect of this factor determined the productivity of the plants by 81.0 and $85.0 \%$, respectively.

Correlation-regression simulation of corn yield indexes depending on the sum of air temperature during the vegetation proved that the best reaction on the improvement of thermal regime is provided by the middle-ripening hybrids (Fig. 3).

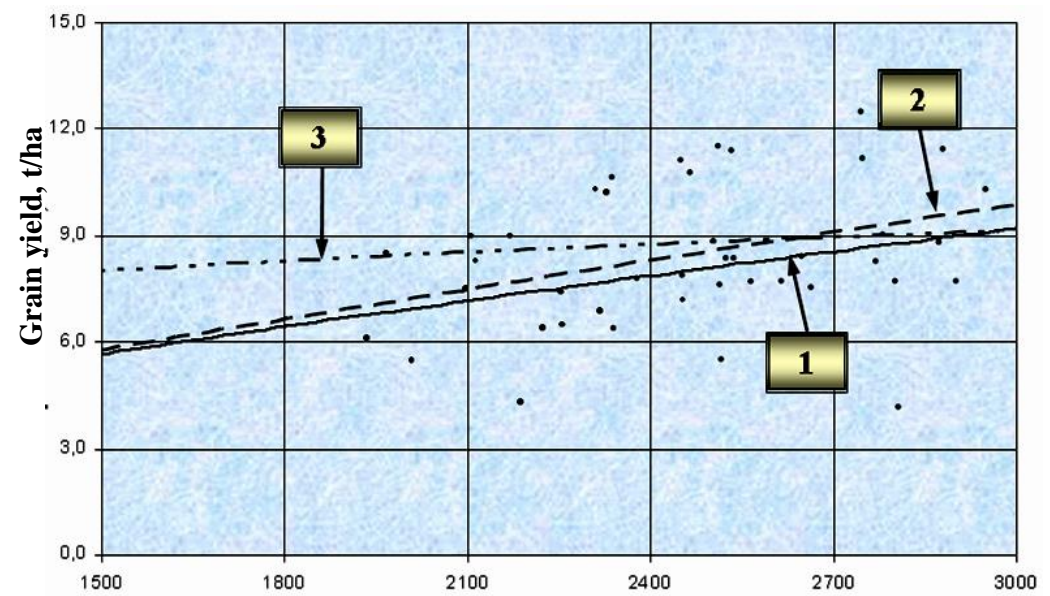

Sum of air temperature, ${ }^{\circ} \mathrm{C}$

Fig. 3. Correlation-regression dependence between the temperature in the period of vegetation and the grain yield of corn hybrids:

1 - Early-ripening $\left(\mathrm{y}=0.0336 \mathrm{x}^{0.7013}\right)$;

2 - Middle-ripening $\left(\mathrm{y}=0.0125 \mathrm{x}^{0.8327}\right)$;

3 - Late-ripening $\left(\mathrm{y}=2.0233 \mathrm{x}^{0.1895}\right)$

On the contrary, early-ripening hybrids require less sum of air temperatures and diminish the yield increase starting with $1500-1600^{\circ} \mathrm{C}$.

Late-ripening corn hybrids are distinguished by some stability of the increase in productivity with the increase in the sum of temperatures, due to a longer period of vegetation and the decrease of thermal regime at the end of summer and, especially, in autumn when the plants are in the final stages of development. 
A negative direction of the connection between the plant productivity and photosynthetic-active radiation was defined (Fig. 4). The calculations proved a slow decrease in the yield of hybrids of all the groups of ripeness under the increase in the income of the PAR, due to the peculiarities of climatic conditions of Southern Steppe of Ukraine, which is characterized by high resources of solar radiation and natural humidification deficiency.

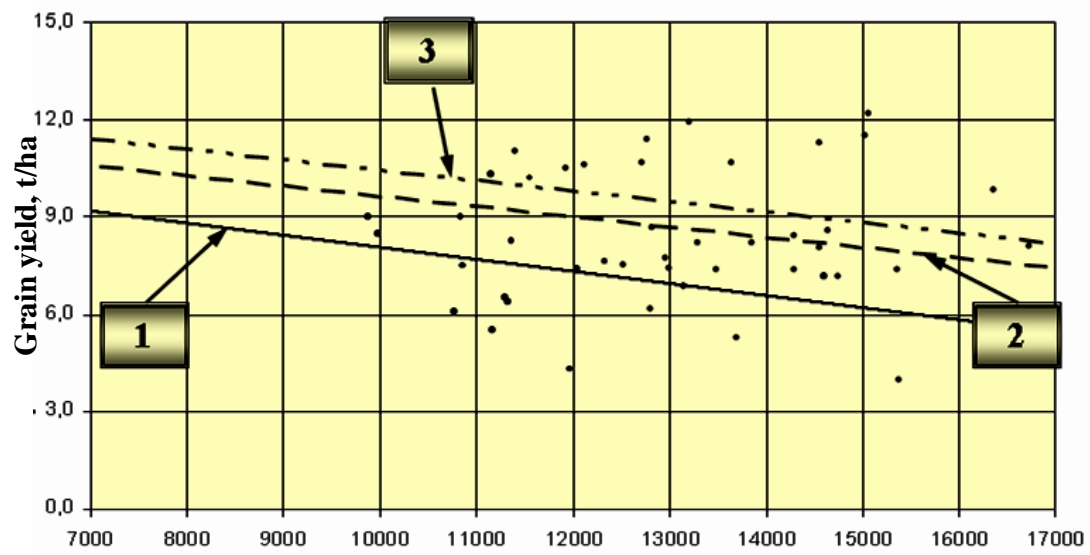

Photosynthetically active radiation, GJ/ha

Fig. 4. Statistical model between the parameters of photosynthetically active radiation and the grain yield of corn hybrids:

1 - Early-ripening $(\mathrm{y}=-0.0004 \mathrm{x}+11.809)$;

2 - Middle-ripening $(y=-0.0003 x+12.906)$;

3 - Late-ripening $(y=-0.0003 x+14.441)$

\section{CONCLUSIONS}

1. Determination of the indexes of photosynthetically active radiation (the PAR) is of great importance from the point of view of comparative assessment of the efficiency of the agricultural land use and the elements of cultivation technologies in different soil and climatic zones. Also, information on the PAR indexes is the basis for the programming of yield, studying the intensity of processes of photosynthesis, agrometeorology and other fields of agrarian science.

2. The highest grain yield of corn hybrids of all the ripening groups was formed in the humid years, and the lowest - in the dry ones, and the plants use the thermal potential of the zone of the South of Ukraine best in the humid and moderately humid years due to the highest intensity of production 
processes. At the corn cultivation for grain it is possible to simulate the duration of the vegetation period using different systems (European, American and Canadian). By the obtained regression equations it is possible to choose the most optimal hybrid composition for regional and local agroclimatic conditions. By the results of the study we determined different degrees of variability for meteorological and agronomic indexes. The use of statistical methods allowed to assess the years of the study by the favorability index of agrometeorological conditions and develop the regression equations of the plant productivity.

3. Statistical analysis of the yielding data of different by ripening groups hybrids of corn and thermal energy indexes allowed to determine different by the degrees and directions connections between the productivity of the plants in the various conditions of natural humidification by the years of the study. Using the created correlation-regression dependences, it is possible to simulate the level of yield of different corn hybrids by the actual parameters of the sum of air temperature and the income of photosynthetically active radiation during the vegetation period of the plants.

\section{SUMMARY}

The article contains the results of the study on the effect of hydrothermal conditions on the productivity of winter wheat and corn at their cultivation at the irrigated lands of Southern Steppe of Ukraine. It was determined that considering the indexes of photosynthetically active radiation income it is possible to develop the basis for the programming of the crop, to study the intensity of photosynthesis processes, improve the knowledge in agricultural meteorology and other fields of agrarian science. It was determined that the maximum grain productivity of corn hybrids of all the ripening groups was formed in the humid years, and the lowest one - in the dry ones, and the plants use the thermal potential of the zone of the South of Ukraine best in the humid and moderately humid years, which is explained by the highest intensity of the production processes. At the corn cultivation for grain it is possible to simulate the duration of the vegetation period using different systems (European, American and Canadian). By the obtained regression equations it is possible to choose the most optimal hybrid composition for regional and local agro-climatic conditions. By the results of the study we determined different degrees of variability for meteorological and agronomic indexes. Statistical analysis of the yielding data of different by ripening groups hybrids of corn and thermal energy indexes allowed to determine different by the degrees and directions connections between the productivity of the plants in the various conditions of natural humidification by the years 
of the study. Using the created correlation-regression dependences, it is possible to simulate the level of yield of different corn hybrids by the actual parameters of the sum of air temperature and the income of photosynthetically active radiation during the vegetation period of the plants.

\section{REFERENCES}

1. Гойса Н. И., Олейник Р. Н., Рогаченко А. Д. Гидрометеорологический режим и продуктивность орошаемой кукурузы. Ленинград: Гидрометеоиздат, 1983. $230 \mathrm{c}$.

2. Яблоков А. В. Популяционная биология. Москва: Высшая школа, 1987. $303 \mathrm{c}$.

3. Григор'єв В. ІВодокористування в умовах недостатнього енергопостачання. Водне господарство Украӥни. Київ. 1997. № 1. С. 6-9.

4. Григоров М. С. Водосберегающие технологии выращивания с.-г. культур. Волгоград: ВГСХА, 2001. 169 с.

5. Ничипорович A. A. Энергетическая эффективность и продуктивность фотосинтезирующих систем как интегральная проблема. Физиология растений. 1978. Т. 25. Вып. 5. С. 922-937.

6. Ничипорович А. А. Фотосинтетическая деятельность растений в посевах. Москва: Издательство АН СССР, 1961. 133 с.

7. Лисогоров К.С., Писаренко В.А. Наукові основи використання зрошуваних земель у степовому регіоні на засадах інтегрального управління природними і технологічними процесами. Таврійський науковий вісник. 2007. Вип. 49. С 49-52.

8. Розробка грунтозахисних ресурсо- та енергозберігаючих систем ведення сільськогосподарського виробництва 3 використанням комп'ютерного програмного комплексу: метод. реком. / розроб. Ю. О. Тараріко; УААН, Ін-т агроекології та біотехнології. Київ: Нора-Друк, 2002. 122 с.

9. Меліоровані агроекосистеми. Оцінка та раціональне використання агроресурсного потенціалу України. Зони зрошення і осушення: [колект. монографія] / за ред. акад. НААМ М. І. Ромащенка, чл.-кор. НААН Ю. О. Тараріко ; Нац. акад. аграр. наук України, Ін-т вод. проблем i меліорації. Київ; Ніжин: Лисенко М. М., 2017. 695 с.

10. Писаренко В.А., Мішукова Л.С., Коковіхін С.В., Присяжний Ю.І. Ефективність різних схем режимів зрошення пшениці озимої в умовах південного Степу України. Зрошуване землеробство. 2008. Вип. 50. C. 31-37.

11. Лавриненко Ю.О. Наукове обгрунтування технології вирощування кукурудзи при краплинному способі поливу: Монографія / 
Ю.О. Лавриненко, В.Б. Рубан, В.Б. Михайленко. Херсон: Айлант, 2014. $198 \mathrm{c}$.

12. Ушкаренко В. О., Нікішенко В. Л., Голобородько С. П., Коковіхін С. В. Дисперсійний і кореляційний аналіз результатів польових дослідів: монографія. Херсон: Айлант, 2009. 372 с.

13. Можаев Н. И., Серикпаев Н. А., Стыбаев Г. Ж. Программирование урожаев сельскохозяйственных культур: учебное пособие. Астана: Высшее образование, 2013. 158 с.

14. Андриевский С. Как выбрать гибрид кукурузы и сэкономить при этом немалые деньги. Зерно. 2006. № 4. С. 36-39.

\section{Information about the Author: Kokovikhin S. V.,}

Doctor of Agricultural Sciences, Professor, Institute of Irrigated Agriculture of the National Academy of Agrarian Sciences of Ukraine Kherson, Naddniprianske, 73483, Ukraine 


\section{BREEDING HERITAGE AND ITS ROLE IN STABILIZING PRODUCTION OF CORN GRAIN IN UKRAINE}

\section{Lavrynenko Yu. O.}

\section{INTRODUCTION}

Providing the Earth's population with food is one of the global problems of the XXI century. It should be noted that at the beginning of a New era population of the Earth was 250-300 million and the population increase was quite slow. At the beginning of the XX century, the population of the world was 1.6 billion people, in $2010-7.0$ billion. In the world scale, agriculture is forced to increase grain production - the main food product for human, concentrated forage and the main source of plant proteins, carbohydrates and fats. Scientific forecasts testify that at significant increase of the population on the Earth, the production of food will not be in pace with such a growth and, according to the existing dynamics, the food problem may be escalated into the deep international $\mathrm{crisis}^{1,2}$.

Fig. 1 shows that the production of grain per capita grew synchronously with the growth of the population from 1960 to 1990 year. Since 1990 the increase in the provision of grain stabilized and it remains almost at the same level. Calculations show that at the current rate of population increase, in the future, the world grain production per person will be reduced. Therefore, humanity should find a solution to the problem, as population increase rates remain very high.

The nominee of the Nobel Prize, the author of «green revolution» Norman Borlaug, in his Nobel lecture made an important warning: «The green revolution provided only temporary success in the war of human against hunger and begging, it gave a temporary rest for human. In the full volume, the revolution can provide a sufficient amount of food for the next three decades. However, the threatening strength of the human reproduction

\footnotetext{
1 Мелик-Саркисов С. Щ. Биотехнология в аграрном секторе США: Экономика развития. М.: Всероссийский НИИ с.-х. биотехнологии РАСХН, 2005. 288 с.

2 Федорук П. С., Федорук С. П., Миренков С. Н. Проблемы и перспективы производства продуктов питания для народонаселения планеты. Научные труды Краснодарского НИИСХ им. П.П. Лукьяненко. Майкоп: Адыгея, 1999. С. 3-15.
} 
should also be limited, otherwise the success of the green revolution will be only ephemeral» ${ }^{3}$.

Threatening are the forecasts of reducing arable land area per capita, as the possibility of expanding agricultural land has almost been exhausted (Fig. 2). If at the beginning of the 20th century the population of the Earth was 1.8 billion people and the arable land area averaged to 0.72 ha per 1 person, then at the beginning of the 21 st century the area of arable land per 1 person decreased to 0.19 ha. Today, almost all land resources have been exhausted and the decrease in agricultural land due to the urbanization of territories and degradation of soils is going on. This indicates that the provision of human food is possible only by increasing the yield of plant production $^{4,5,6,7,8}$.

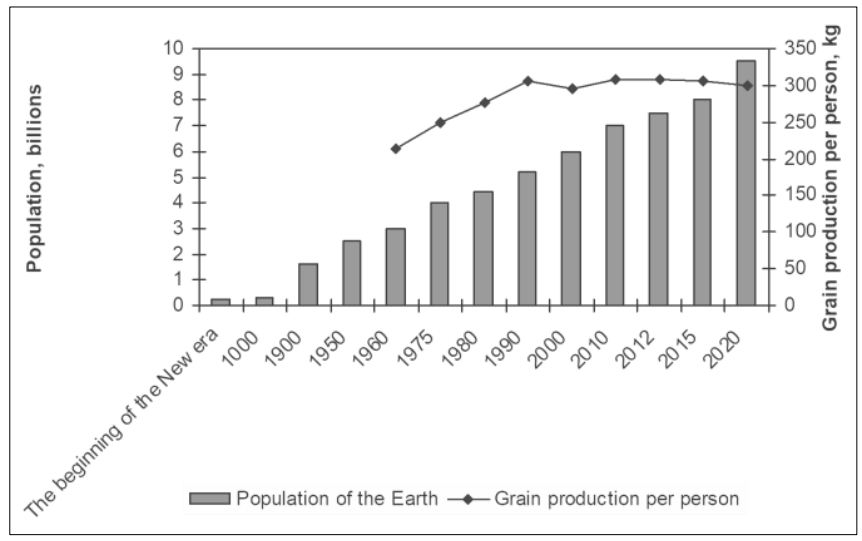

Fig. 1. World population dynamics on the Earth and grain production per person

${ }^{3}$ Nobel Lectures, Peace 1951-1970, Editor Frederick W. Haberman, Elsevier Publishing Company, Amsterdam, 1972 MLA style: «Norman Borlaug - Nobel Lecture: The Green Revolution, Peace, and Humanity».Nobelprize.org. Nobel Media AB 2013. Web. 9 Mar 2014. http://www.nobelprize.org/nobel_prizes/peace/laureates/1970/borlaug-lecture.html

${ }_{4}^{4}$ Джей Форрестер. Мировая динамика / Пер. с англ. А. Ворощука, С. Пегова. М.: ООО «Издательство АСТ; СПб.: Terra Fantastica, 2003. 379 с.

${ }^{5}$ Марфенин Н.Н. Устойчивое развитие человечества. М.: Изд-во МГУ, 2006. 612 с.

${ }^{6}$ Капица С. П. Демографическая революция и будущее человечества. В мире науки. 2004. №4. C. 82-91.

7 United Nations Population Division, World Health Organization (WHO), Food and Agriculture Organization (FAO), International Monetary Fund (IMF), and World Bank. http://www.worldometers.info/world-population/

${ }^{8}$ Народонаселение. Организация Объединенных Наций http://www.un.org/ru/sections/ issues-depth/population/ $\mathrm{OOH}$ 
Therefore, in the field of increasing productivity of grain crops (main source of foodstuffs), three main directions are possible: genetics-selection development; creation and improvement of agrotechnologies; optimization of allocation and specialization of production ${ }^{1,2}$.

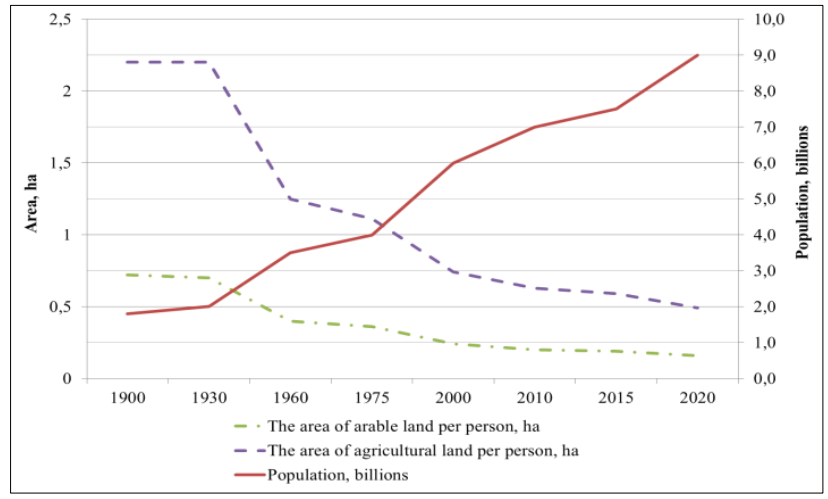

\section{Fig. 2. Projected area of arable land and agricultural lands, attributable to the population of the Earth}

For the whole thousand-years history of human civilization on the Earth, the main grains of mankind were wheat and rice. But at the beginning of the third millennium, the first place (by the gross harvest and yields) came to corn. For today, world corn production exceeds 1 billion tons of grain and in the coming years it is expected to increase of yields and gross harvest (Fig. 3).

As it is evident from the Figure 3, the gross harvest of rice and wheat have almost stabilized since the third millennium, but corn has a clear tendency to increase gross production. The main countries-producers are industrially developed, such the US, France, Italy or the dynamically developing countries - China, India, Romania, Brazil ${ }^{9} 10$.

The main increase of the world gross harvest of grain crops in 60-90-s was provided by the growth in yields (Fig. 4). This happened owing to the green revolution, which was launched by the Nobel Prize nominee Norman Borlaum for the introduction of new intensive wheat varieties and was spread in rice and corn.

\footnotetext{
${ }^{9}$ Food and Agriculture Organization of the United Nations http://www.fao.org/faostat/ en/\#data/QC ${ }^{9}$

${ }^{10}$ United States Department of Agriculture. Foreign Agricultural Service. http://www.usda crop explorer: global crop production analysis.
} 


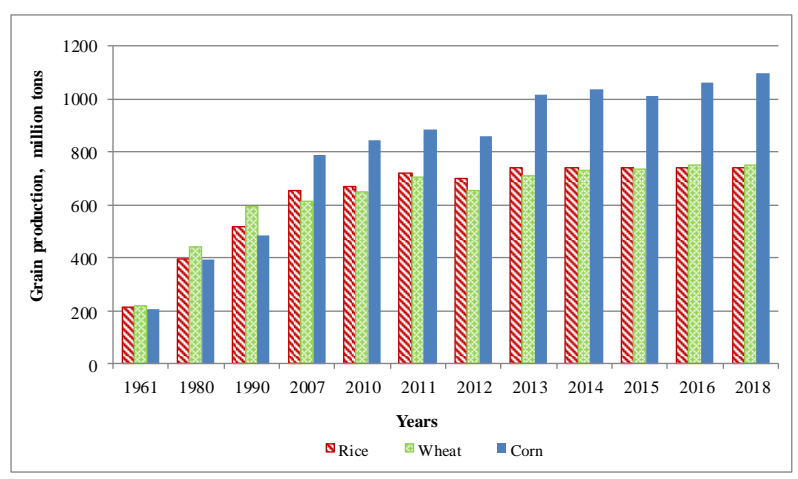

Fig. 3. The dynamics of the world's main grain crops production, million tons

This emphasizes the importance of the main direction in the productivity improvement - breeding and genetic development. By the testimony of the leading scientists, the increase in yield and gross harvest in recent years is possible owing to the breeding development by $50-80 \%{ }^{11} 12$.

That is why breeding developments of crops are actively engaged by scientists in the leading countries of the world.

The breeding of corn has made significant progress in the breeding centers of North America and European countries. This is evidenced by the fact that corn is consistently ahead by the yield for wheat and rice, which gave the impulse for increasing the sowing areas of these crops in the countries with dynamic development of agriculture.

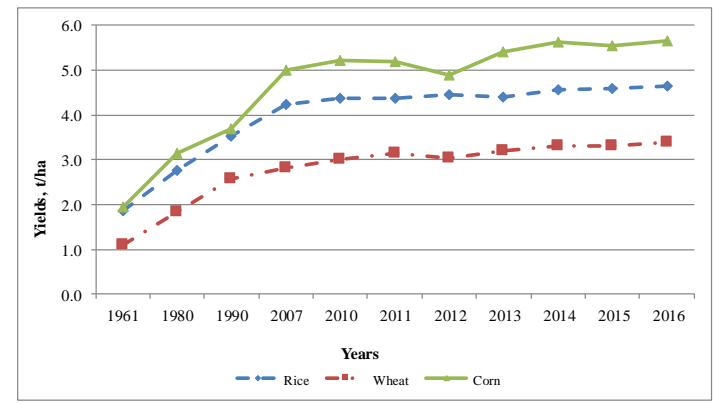

Fig. 4 The dynamics of the world yields of main grain crops, t/ha

\footnotetext{
${ }_{11}^{11}$ Созінов О. О. Нові рубежі в селекції рослин. Вісник аграрної науки. 2000. № 12. С. $22-24$.

${ }^{12}$ Рив М. Генетика и наследственность. М.: Мир, 1987. С. 251-276.
} 
Ukraine has intentions and opportunities to occupy an honorable place among the leading developed countries of the world by the economic indexes of the agrarian sector, and has already declared itself as a powerful producer and exporter of grain (Fig. 5). The rapid growth of corn production is due to the extremely high positive reactions to genetic shifts and technological developments. Breeders of Ukraine created corn hybrids with a certain level of adaptability to specific agro-ecological zones and technologies. The introduction of a new generation hybrids made it possible to increase the yield of grain over the past decade from 2.62 t/ha to 7.80 t/ha (Fig. 5).

By the yield of grain in 2018, Ukraine was ahead of the EU countries (Fig. 6). It should be noted that this crop is not yet in line with the potential capabilities of modern hybrids, but among the major global producers of corn, Ukraine takes the third position. Owing to the introduction of innovative hybrids, Ukraine entered into the six main producers of corn grain in the world and the top five exporters.

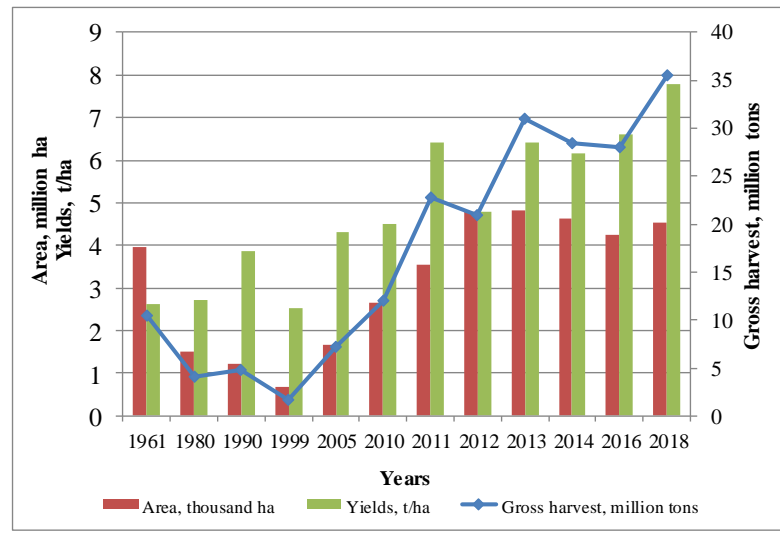

Fig. 5 Dynamics of corn grain production in Ukraine

Ukraine is one of the world's leading producers of corn grain, gross harvest exceeds 30 million tons ${ }^{9,10}$. The fundamental direction of the increase in corn yield is the introduction of hybrids of intensive type with low harvesting moisture that will provide an opportunity of spreading the areal of their use. 


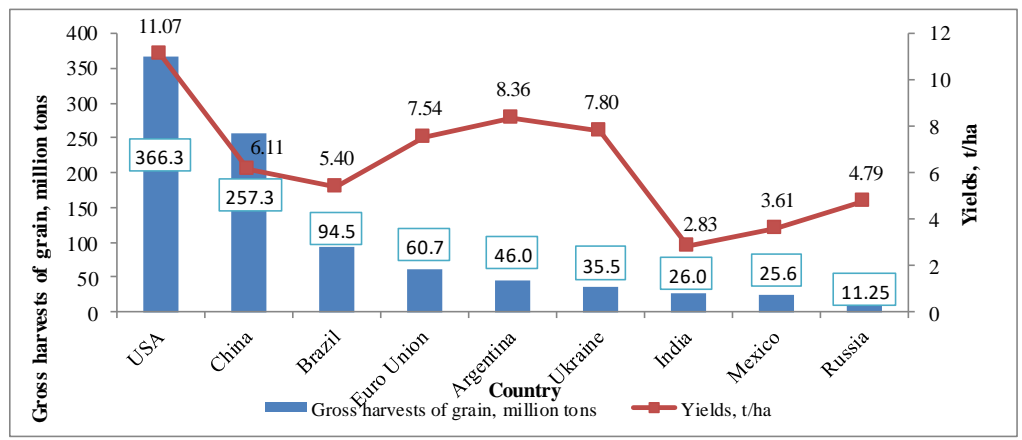

\section{Fig. 6 Gross harvest and yields of the world grain producers of corn (2018)}

The important role in the increase of yields and improvement of grain quality is played by the correct hybrids selection for cultivation. Highperformance hybrids uptake a large amount of nutrients from the soil, consume plenty of water, so such hybrids require appropriate agricultural technology. If such conditions are absent, the potentially more productive hybrid not only does not increase, but may provide a yield less than another less productive, but less demanding to the cultivation, hybrid ${ }^{13,14}$. So, we need differentiated approach to the selection of hybrids of the corresponding group of ripeness and purpose. To improve the implementation of the yield potential of modern hybrids, the development of morpho-physiological and heterobreeding models and hybrids selection on this basis with specific adaptability to agroecological factors is important ${ }^{15,16}$.

\section{Materials and methods of researches}

The accelerated obtaining of new varieties and hybrids, which are characterized by high and sustainable yields with the improved quality

\footnotetext{
${ }^{13}$ Munsch M. A., Stamp P., Christov N. K., Foueillassar X. M., Hüsken A., Camp K. H., Weider Ch. Grain Yield Increase and Pollen Containment by Plus-Hybrids Could Improve Acceptance of Transgenic Maize. Crop Science. 2010. Vol. 50, Iss. 3. P. 909-919.

${ }^{14}$ Vozhegova R. A., LavrinenkoYu. O., Hlushko T. V. Productivity of maize hybrids of different FAO groups depending on condition of irrigation and dosage of fertilizers in the southern steppe of Ukraine. Agricultural Science and Practice. 2014. Vol. 1. No. 3. P. 62-68.

${ }^{15}$ Troyer A. F. Background of U.S. hybrid corn: II. Breeding, climate and food. Crop Science. 2004. Vol. 44, Iss. 2. P. 370-380.

${ }^{16}$ Мустяца С. И., Мистрец С. И. Использование зародышевой плазмы гетерозисных групп БССС и Рейд Айодент в селекции скороспелой кукурузы. Кукуруза и сорго. 2007. № 6. С. $8-12$.
} 
indicators of grain, is assisted by the observance of a specific model of the crop in the process of creation and selection of appropriate genotypes. Model of variety includes both characteristics of productivity and characteristics indicating the relationship of the plant's body to the environmental elements. Developing an agricultural model requires information about the parameters of quantitative productivity indexes and their dependence on the indexes of morphology, physiology, specific adaptability, the combination ability of output lines and the application of appropriate heterosis plasms.

The task of the research was to develop morpho-physiological and heterosis models of corn hybrids and to create on their basis corn hybrids with FAO of 150-600 for the conditions of sufficient natural humidification and artificial irrigation with the yield of grain of.11,0-17.0 t/ha.

The research methods used: field, laboratory, statistical, selective genetic, retrospective.

The researches were performed during 2007-2017 in the Department of Plant Breeding of the Institute of Irrigated Agriculture of NAAS and Askanian State Research Station. The study was conducted with accordance to the relevant methodological requirements ${ }^{17,18}$.

\section{The results of the research}

The use of correlation-regression connections of quantitative productivity characteristics allowed to develop morpho-physiological and heterosis models of corn hybrids and to create on their basis corn hybrids with FAO of 150-600 for the conditions of artificial irrigation with grain yield of 11.0$17.0 \mathrm{t} / \mathrm{ha}$. The models of corn hybrids of five groups of ripeness were developed: the early ripening (FAO 150-190), the middle-early ripening (FAO 200-290), the middle ripening (FAO 300-390), the middle-late ripening (FAO 400-490), the late ripening (FAO 500-600), which corresponded to the requirements of adaptability to the conditions of irrigation (Table. 1).

The most stable in the conditions of southern region were the hybrids of the early ripening group of FAO 150-190, which are used for cultivation in post-mowing, post-harvest crops and as a fore-crop for winter crops. The potential yield of this group is considerably lower than of the late ripening one due to the reduced duration of the vegetative period. The model of the early ripening group hybrids of corn in the conditions of irrigated agriculture

17 Домашнев П. П., Дзюбецкий Б. В., Костюченко В. И. Селекция кукурузы. М.: Агропромиздат, 1992. 204 с.

${ }_{18}$ Ушкаренко В. А., Лазарев Н. Н., Голобородько С. П., Коковихин С. В. Дисперсионный и корреляционный анализ в растениеводстве и луговодстве. Москва: Изд-во РГАУ - МСХА имени К. А. Тимирязева, 2011. 336 с. 
should have genetic potential of grain yield at $10.5-11.5 \mathrm{t} / \mathrm{ha}$ under the optimal technological conditions of growing (see Table 1).

The South of Ukraine is characterized in the recent years by the fact that most of its territory is under the cultivation of the corn hybrids of the middle-early ripening group of FAO 200-290. The genotypes of this group have high potential yield, the vegetation period lasts in the South Steppe for 100-110 days, they are undemanding to agrotechnical support, resulting in a guaranteed ripening every year. Under the optimal conditions of cultivation and in compliance with the technology of cultivation corn hybrids of middleearly group of ripeness should have the yield of grain within 11.5-12.5 t/ha, grain outlet $-88-90 \%$, weight of grain per cob $-200-240 \mathrm{~g}$, weight of 1000 seeds $-270-310 \mathrm{~g}$ (see Table 1 ).

Table 1

Morpho-physiological parameters of the models of corn hybrids of FAO 150-600 for the conditions of irrigation in the South of Ukraine (2009-2015)

\begin{tabular}{|c|c|c|c|c|c|}
\hline Indicators & $\begin{array}{c}\text { FAO } \\
\mathbf{1 5 0 - 1 9 0}\end{array}$ & $\begin{array}{c}\text { FAO } \\
\mathbf{2 0 0 - 2 9 0}\end{array}$ & $\begin{array}{c}\text { FAO } \\
\mathbf{3 0 0 - 3 9 0}\end{array}$ & $\begin{array}{c}\text { FAO } \\
\mathbf{4 0 0 - 4 9 0}\end{array}$ & $\begin{array}{c}\text { FAO0-600 } \\
\mathbf{5 0 0}\end{array}$ \\
\hline Yield of grain, t/ha & $10.5-11.5$ & $11.5-12.5$ & $12.5-14.5$ & $14.5-17.0$ & $16.0-18.0$ \\
\hline $\begin{array}{c}\text { Harvesting moisture } \\
\text { of grain, \% }\end{array}$ & $12-13.0$ & $12.0-13.0$ & $13.5-14.0$ & $87-90$ & $85-88$ \\
\hline Grain yield, \% & $87-90$ & $87-90$ & $88-90$ & $240-260$ & $270-290$ \\
\hline Grain weight per cob, g & $180-200$ & $200-240$ & $220-240$ & $13.5-14.5$ & $16-18$ \\
\hline Weight of 1000 seeds, g & $250-280$ & $270-310$ & $280-320$ & $300-320$ & $300-340$ \\
\hline Length of the cob (full), cm & $16,0-18,0$ & $18-20$ & $20-21$ & $20-23$ & $20-24$ \\
\hline $\begin{array}{c}\text { Length of the cob } \\
\text { with grain, cm }\end{array}$ & $16.0-18.0$ & $18-20$ & $20-21$ & $19.5-22.0$ & $20-24$ \\
\hline Diameter of the cob, cm & $4.2-4.5$ & $4.5-4.8$ & $4.6-5.0$ & $5.0-5.2$ & $5.5-5.7$ \\
\hline Number of rows, pcs & $14-16$ & $14-16$ & $16-18$ & $18-22$ & $18-24$ \\
\hline Number of grains, pcs & $40-45$ & $42-45$ & $46-48$ & $48-50$ & $46-52$ \\
\hline Core diameter, cm & $2.0-2.3$ & $2.3-2.4$ & $2.4-2.8$ & $2.4-2.6$ & $2.6-2.8$ \\
\hline $\begin{array}{c}\text { Photosynthetic potential, } \\
\text { thousanf } \text { m }^{2 *} \text { days }\end{array}$ & 1500 & 2500 & 2950 & 3200 & 3500 \\
\hline Leaf area index (LAI) & 3.8 & 5.0 & 5.6 & 6.0 & 6.0 \\
\hline
\end{tabular}

The main element of cost-effective production of middle-ripening hybrids is the harvesting by the direct threshing, which provides saving of funds for drying, due to low harvesting moisture of grain. For this purpose, it is especially important to create a morpho-physiological model of the middle-ripening corn group of FAO 300-390 (see Table 1). Hybrids of the middle-ripening model of corn hybrids are high-yielding, this is testified by the high productivity indexes: grain yield is $12.5-14.5 \mathrm{t} / \mathrm{ha}$, grain outlet $88.0-90.0 \%$, weight of grain per cob - 220-240 g, weight of 1000 seeds 280-320 g. The corn hybrids of this group of ripeness should have the potential to form plants with two cobs. 
The development of heterosis model and the use of modern germplasm is an important factor of effective plant breeding ${ }^{19}$. The creation of fundamentally new adaptive hybrids of corn requires the use of traditional heterosis models and creation of new elite lines based on the mixed germ plasm, formed on the basis of new industrial hybrids. The analysis of usage of the basic germ plasma in recent years has shown that, along with traditional heterosis groups, the number of the lines created on the basis of new commercial hybrids, the so-called «mixed plasma», is increasing (Table. 2). It should be noted that the major germ plasma has survived today in working collections in a rather modified condition, and it is sometimes possible to obtain hybrids with a sufficiently high level of contest heterosis and within a single source plasma.

Table 2

The use of the lines of basic germ plasma in the hybrids of corn of the contest variety-testing with FAO 150-390 (2007-2015)

\begin{tabular}{|c|c|c|c|c|c|c|}
\hline \multirow{2}{*}{$\begin{array}{c}\text { Origin of the } \\
\text { input material }\end{array}$} & \multicolumn{7}{|c|}{ FAO 150-200 } & \multicolumn{2}{c|}{ FAO 200-290 } & \multicolumn{2}{c|}{ FAO 300-390 } \\
\cline { 2 - 7 } & $\begin{array}{c}\mathbf{2 0 0 7 -} \\
\mathbf{2 0 1 0}\end{array}$ & $\begin{array}{c}\mathbf{2 0 1 1 -} \\
\mathbf{2 0 1 5}\end{array}$ & $\begin{array}{c}\mathbf{2 0 0 7 -} \\
\mathbf{2 0 1 0}\end{array}$ & $\begin{array}{c}\mathbf{2 0 1 1 -} \\
\mathbf{2 0 1 5}\end{array}$ & $\begin{array}{c}\mathbf{2 0 0 7 -} \\
\mathbf{2 0 1 0}\end{array}$ & $\begin{array}{c}\mathbf{2 0 1 1 -} \\
\mathbf{2 0 1 5}\end{array}$ \\
\hline Lakaune & 22.4 & 12.7 & 4.5 & 6.3 & 0.8 & 0.5 \\
\hline S72 & 18.0 & 8.7 & 3.2 & - & - & - \\
\hline P502 & 14.3 & 9.5 & 17.6 & 8.6 & 4.3 & 2.3 \\
\hline P346 & - & - & 16.7 & 7.5 & 0.7 & - \\
\hline Lancaster (OH43) & 13.5 & 18.4 & 5.3 & 13.2 & 18.9 & 15.4 \\
\hline Lancaster (C103) & - & - & - & - & - & 2.7 \\
\hline Raid (WF9) & 24.6 & 25.3 & 23.6 & 27.8 & 8.4 & 7.4 \\
\hline Raid (SSS) & - & - & - & - & - & 2.3 \\
\hline Aiodent & - & 9.8 & 15.3 & 23.4 & 38.6 & 41.1 \\
\hline T 22 & - & - & 5.2 & 0.7 & 7.5 & - \\
\hline Other & - & - & 5.6 & 2.0 & 3.1 & 2.8 \\
\hline Mixed plasma & 7.2 & 15.6 & 3.0 & 10.5 & 17.7 & 25.5 \\
\hline
\end{tabular}

The corn hybrids of the middle-late (FAO 400-490) and late (FAO 500600 ) ripeness group have the highest productivity potential. However, this group of ripeness until now did not always meet the requirements of modern technologies of cultivation, associated with the grain harvesting by combines with direct threshing and required harvesting moisture at the level of 13$16 \%$. The models of such high-productive hybrids and self-pollinated paternal lines have been developed, meeting the requirements concerning the technological cultivation of corn in the conditions of irrigation.

19 Дзюбецький Б. В., Черчель В. Ю. Сучасна зародкова плазма в програмі з селекції кукурудзи в Інституті зернового господарства УААН. Селекція і насінництво. Харків, 2002. № 86. С. 11-19. 
In the developed model of the middle-late group (FAO 400-490) the following quantitative characteristics have been formed that formed the grain yield at the level of 14-17 t/ha. Grain weight per cob is 240-260 g, weight of 1000 seeds $-300-320 \mathrm{~g}$, grain outlet $-87-90 \%$. The cob is of medium size, the 3 full length $-20-23 \mathrm{~cm}$, length of the cob with grain $-19.5-22.0 \mathrm{~cm}$. The main structural elements of the cob had the following characteristics: the diameter of the cob $-5.0-5.2 \mathrm{~cm}$, the core diameter $-2.4-2.6 \mathrm{~cm}$, the core is red. The cob is cylindrical. Photosynthetic potential is 3200 thousand $\mathrm{m}^{2}$ *day, leaf area index -6.0 (Table 1).

The corn hybrids of the late ripening group by FAO are the most productive in the South of Ukraine under the obligatory presence of irrigation. However, it should be noted that the hybrids of corn with FAO 500-600 not every year can form a ripe grain because of the insufficient number of effective temperatures and cool wet autumn. Studies have established that in the third decade of September and October, the drying of the grain is significantly delayed and it is not $1.2-1.5 \%$ as in August - the first half of September, and decreases to $0.1-0.5 \%$ (secondary humidifying of grain in rainy weather can occur) ${ }^{20}$. Therefore, cultivation of the corn hybrids of late group of ripeness is associated with certain risk for production. The following parameters of the morpho-physiological model of the corn hybrids of late group are determined - the yield of grain of 16-18 $\mathrm{t} / \mathrm{ha}$, the grain outlet $-85-88 \%$. The average value of a grain weight per cob is $270-290 \mathrm{~g}$ (see Table 1 ).

Analysis of usage in the recent years of the basic germ plasma of FAO 400-600 has shown that the share of the lines created on the basis of new synthetic populations (mixed plasma) is increased along with traditional heterosis groups (Table 3). The line of plasma Raid (SSS) and Lancaster (C103) underwent a significant selection revision, mainly in the direction of the speeding up the loss of moisture at the ripening period.

This is especially true for the group of lines with FAO more than 500 . So, if the base lines X18, B73, X18-1, X902 (parental forms of hybrids Perekop, Borysfen 600) provided the level of grain yield up to $15 \mathrm{t} / \mathrm{ha}$, however, the harvesting moisture of the grain was at the level of $25-30 \%$ that is unacceptable for modern corn cultivation technologies. Besides, the hybrids with FAO of 500-600 are very sensitive to the technological conditions of cultivation and the slightest disruption of the technological regulations leads to drastic decrease in yield, which eliminates their potential and leads to economic losses. That is why, selection of hybrids with FAO

\footnotetext{
${ }^{20}$ Плоткін С. Я., Лазер П. Н., Йокич Д. Р. Еколого-генетична детермінація добової втрати вологи зерном при дозріванні у гібридів кукурудзи в умовах південного Степу. Таврійський науковий вісник. 2003. Вип. 26. С. 37-45.
} 
500-600 in the conditions of irrigation of the South of Ukraine today has little prospects and is held in a limited volume.

Table 3

The use of lines of basic germ plasma in the hybrids of corn of the contest variety-testing of FAO 400-600 (2007-2015)

\begin{tabular}{|c|c|c|c|c|}
\hline \multirow{2}{*}{$\begin{array}{c}\text { Origin of the input } \\
\text { material }\end{array}$} & \multicolumn{4}{|c|}{ Ripeness group by FAO } \\
\cline { 2 - 5 } & \multicolumn{2}{|c|}{ FAO 400-490 } & \multicolumn{2}{c|}{ FAO 500-600 } \\
\cline { 2 - 5 } & $\mathbf{2 0 0 7 - 2 0 1 0}$ & $\mathbf{2 0 1 1 - 2 0 1 5}$ & $\mathbf{2 0 0 7 - 2 0 1 0}$ & $\mathbf{2 0 1 1 - 2 0 1 5}$ \\
\hline Lancaster (OH43) & 11.5 & 5.6 & - & - \\
\hline Lancaster (C103) & 15.6 & 14.8 & 8.3 & 6.3 \\
\hline Raid (WF9) & 2.3 & 1.5 & - & - \\
\hline Raid (SSS) & 17.8 & 14.2 & 45.6 & 44.7 \\
\hline Aiodent & 36.9 & 33.1 & - & - \\
\hline Other & 1.2 & 1.5 & 2.3 & 1.2 \\
\hline Mixed plasma & 14.7 & 29.3 & 43.8 & 47.8 \\
\hline
\end{tabular}

The main germ plasma has survived today in working collections in a rather modified condition, and sometimes it is possible to obtain hybrids with a sufficiently high level of contest heterosis and within a single source plasma.

It is typical that among the linear material of FAO 400-490 there is a fairly large range of original elite material, which provides for hybrid combinations with a programmed level of yield, however, the elite material input material of the group of FAO 500-600 islvery Limited. This is due to the fact that the selection of hybrids with FAO more than 500 is limited in the main plant breeding institutions of Ukraine and Europe, which is primarily due to the high expenditures for grain drying.

The formation of the maximum yield of a hybrid depends on a number of factors, one of which is the cultivation zone, where the resources of the environment correspond to the biological optimum of the genotype. For each region, there are their optimum models of new corn hybrids and in accordance with this, plant breeding work is carried out. On the basis of the developed models, in the cooperation between the Institute of Irrigated Agriculture and the Institute of Cereal Crops of NAAS, new hybrids of corn having the adaptation to the conditions of irrigation, various irrigation regimes, an adequate projected response to the technological support and high productivity potential were created.

Modern hybrids of corn, created for irrigated conditions, has to be transferred to production with certain parameters of technological requirements, and especially for irrigation regimes and ways of irrigation. The studies, which were carried out on different irrigated arrays, various 
ways of irrigation and irrigation regimes, provided an opportunity to provide the production the adaptation parameters for the certain hybrids to specific agro-ecological and technological peculiarities. In the Table 4, the productivity of modern corn hybrids, created for irrigated conditions, depending on the way of irrigation and water supply regime on the main irrigated arrays of the South of Ukraine is presented.

Table 4

Grain yield (t/ha) of corn hybrids at various ways of irrigation and irrigation regimes (2016-2017)

\begin{tabular}{|c|c|c|c|c|c|}
\hline Hybrid & FAO & $\begin{array}{c}\text { Watering } \\
\text { with } \\
\text { sprinkler } \\
\text { machine } \\
\text { DDA 100 } \\
\text { MA, } \\
\text { Ingulets } \\
\text { irrigated } \\
\text { array, TAW } \\
\text { at 70\% FC } \\
\end{array}$ & $\begin{array}{c}\text { Watering } \\
\text { with drip } \\
\text { irrigation, } \\
\text { Ingulets } \\
\text { irrigated } \\
\text { array, TAW } \\
\text { at } 80 \% \text { FC }\end{array}$ & $\begin{array}{c}\text { Watering } \\
\text { with drip } \\
\text { irrigation, } \\
\text { Ingulets } \\
\text { irrigated } \\
\text { array, TAW } \\
\text { at } 85 \% \text { FC }\end{array}$ & $\begin{array}{c}\text { Watering } \\
\text { with } \\
\text { sprinkler } \\
\text { machine } \\
\text { Zimmatic, } \\
\text { Kakhovka } \\
\text { irrigated } \\
\text { array, TAW } \\
\text { at } 80 \% \text { FC }\end{array}$ \\
\hline DN Pivikha & 190 & 9.31 & 10.16 & 11.02 & 10.73 \\
\hline Tendra & 190 & 8.83 & 9.25 & 10.46 & 9.90 \\
\hline Oberig & 190 & 9.86 & 10.22 & 11.37 & 10.74 \\
\hline DN Hawtin & 250 & 10.56 & 12.44 & 13.07 & 12.83 \\
\hline DN Galateya & 250 & 10.43 & 11.90 & 13.15 & 12.36 \\
\hline $\begin{array}{c}\text { Orzhytsya } \\
237 \mathrm{MV}\end{array}$ & 250 & 9.54 & 10.73 & 10.90 & 10.54 \\
\hline Korund & 280 & 10.15 & 11.61 & 13.51 & 12.43 \\
\hline Skadovskyi & 280 & 10.82 & 11.05 & 11.94 & 11.48 \\
\hline DN Rostock & 300 & 8.96 & 12.34 & 14.64 & 12.42 \\
\hline DN Demetra & 300 & 8.77 & 12.04 & 13.33 & 12.11 \\
\hline DN Aquazor & 320 & 9.64 & 12.45 & 14.17 & 12.10 \\
\hline DN Zbruch & 350 & 9.16 & 12.36 & 14.48 & 12.59 \\
\hline DN Vizyr & 350 & 8.95 & 12.07 & 13.23 & 12.65 \\
\hline Kakhovskyi & 350 & 8.90 & 13.01 & 13.17 & 12.74 \\
\hline Azov & 380 & 8.13 & 12.18 & 13.34 & 13.16 \\
\hline DN Bereka & 390 & 9.50 & 13.63 & 15.28 & 14.17 \\
\hline DN Hetera & 420 & 8.32 & 14.48 & 17.14 & 13.77 \\
\hline DN Anshlag & 420 & 8.93 & 15.03 & 17.43 & 13.71 \\
\hline DN Rawa & 420 & 8.54 & 14.82 & 16.85 & 14.42 \\
\hline Arabat & 430 & 7.98 & 16.40 & 17.81 & 14.34 \\
\hline Prymorskyi & 420 & 8.04 & 14.35 & 15.47 & 13.17 \\
\hline Chonhar & 430 & 8.91 & 14.03 & 14.42 & 13.44 \\
\hline $\mathrm{LSD}_{05}$ & & 0.31 & 0.42 & 0.41 & 0.34 \\
\hline
\end{tabular}

To set the norm of the reaction for newly created hybrids depending on the technological conditions, we investigated the influence of such irrigation 
ways and regimes: watering with sprinkler irrigation machine DDA $100 \mathrm{MA}$ at Ingulets irrigated array with a level of soil moisture content of $70 \%$ FC (TAW at $70 \%$, water-saving mode); watering with drip irrigation, Ingulets irrigated array, TAW moisture content at $80 \%$ FC; drip irrigation, Ingulets irrigated array, TAW soil moisture at $85 \%$ FC (optimal regime); watering with irrigation machine Zimmatic, Kakhovka irrigated array, TAW soil moisture at $80 \% \mathrm{FC}$.

It is determined that the hybrids with FAO 190 have sustainable yield indexes at different regimes of irrigation. Use of these hybrids is advisable for the water-saving regimes of irrigation on the irrigated lands with a low hydro-module capacity.

The best in the indexes of yield plasticity among the hybrids of middleearly group of ripeness (FAO 190-280) was hybrid Hawtin (FAO 250), independently on the way of irrigation. Thus, watering in the area of the Ingulets irrigated array, there was the yield at the level of $10.56 \mathrm{t} / \mathrm{ha}$, and at the cultivation in the zone of the Kakhovka irrigation system $-12.83 \mathrm{t} / \mathrm{ha}$. It became the best in his group of ripeness at the cultivation under the drip irrigation with TAW soil moisture at the level of 80 and $85 \%$ FC, where the yield of hybrid Hawtin was 12.44 and 13.07 t/ha. For the use of TAW soil moisture at $85 \% \mathrm{FC}$, the best among the early ripening and middle-early hybrids of corn was the hybrid Korund $-13.51 \mathrm{t} / \mathrm{ha}$.

Among the middle-ripening hybrids (FAO 300-390) at the irrigation within the Ingulets array, the strong reaction of hybrids to the ecological gradient of cultivation was observed. Yield of the hybrids of this type drastically decreases at the use of water-saving irrigation regimes. These hybrids belong to the intensive type and dramatically reduce the yield of grain below the level of the hybrids with FAO 190-280. It is not reasonable to use them at water-saving irrigation regimes, and it can lead to the yield losses. Genotypical capacity of the productivity of these hybrids can be opened only under the conditions of intensive technologies. At the TAW at $85 \%$ FC and drip irrigation, the yield of grain of the hybrids DN Aquazor, DN Bereka, DN Zbruch, DN Rostock reached 14-15 t/ha.

In the group of middle-late hybrids there are domestic corn hybrids of the intensive type Arabat, DN Hetera, DN Anshlag, DN Rawa, which provide the yield of grain of 15-17 t/ha at drip irrigation and sprinkler irrigation in the conditions of Ingulets and Kakovka irrigated arrays independently on the water quality. It is unreasonable to use the hybrids of this at the irrigated lands with a low hydro-module capacity and water-saving regimes, as this technology leads to significant losses of yield and they become noncompetitive with modern hybrids of FAO 190-280. These hybrids are not 
worse in grain yield to the best world analogues and have a predictable reaction on the level of technological support. This allows providing the production with not only domestic selective product, but at the same time the varietal technology, which is oriented on the soil-ecological zone, hydromodule capacity, crop rotation structure, the level of financial support of the farm.

The plastic hybrids of corn of the FAO 180-290 group Pivikha, Khotyn, Skadovskyi, which provide the level of grain yield of 8-9 t/ha under the use of water-saving irrigation regime, save irrigation water volumes within 30$35 \%$, and which are good fore-crops for winter cereals, for use of the sprinkler irrigation way on the systems with limited hydro-module capacity, are determined.

Thus, the production is proposed to use modern domestic corn hybrids of the intensive type Arabat, Anshlag, Hetera, Zbruch, Azov, Rostock at drip irrigation and sprinkler irrigation using TAW level at $80-85 \%$ FC, which provides the grain yield of 15-17 t/ha.

At the use of sprinkler irrigation method in the zones with a limited hydro-module capacity, which does not allow increasing TAW level more than of 70\%, it is necessary to use plastic hybrids of the FAO groups 180290 DN Pivikha, Khotyn, Korund, Sadovskyi, Solonianskyi 298SV, which provide grain yield level of 9-10 t/ha at the use of water-saving regime of irrigation, saving irrigation water volumes within $1200-1500 \mathrm{~m}^{3} / \mathrm{ha}$, and which are good fore-crops for winter cereal crops because of the early terms of harvesting in the third decade of August.

Summarizing the results of the corn selection for the irrigated conditions, it is possible to draw conclusions that universal hybrids adapted to a wide range of environmental conditions are inferior in productivity to the genotypes of narrow adaptability on every agroecological. By the adaptive properties we have to distinguish: the hybrids of the intensive type with strongly expressed reaction to the environment; homeostatic, which provide sustainable yields under the fluctuations of cultivation conditions; plastic, which adequately react to the changes of the level of agro-background.

To select for the adaptability, an ecological gradient, objectively reflecting the spectrum of agroecological conditions in the presumed region of the distribution of the corn hybrid, should be provided.

To obtain high and sustainable grain yield in every farm of the irrigated zone of the Steppe of Ukraine, it is obliged to have a specter of hybrids that have different type of reaction to changing environment: the intensive type to obtain the maximum yields on the best irrigated fields; homeostatic - to obtain guaranteed yield on the worse and rain-fed fields; moderately plastic with wide adaptive potential - to obtain relatively sustainable yield in the 
fields with an unstable agro-background (fields with a low hydro-module capacity of irrigation system).

\section{CONCLUSIONS}

In the conditions of irrigation, it is necessary to use corn hybrids with a genetically predicted reaction to the optimal cultivation conditions (optimal regime of soil moisture and mineral nutrition). Violation of cultivation technology leads to significant losses of grain yields, especially in the hybrids of the late ripening group. With the use of the developed morphobiological and heterosis model, it was possible to create corn hybrids of the intensive type with programmed parameters, which could be used in different agro-climatic zones and to realize the programmed grain yield.

Hybrids of the intensive type have a complex of economic and valuable characteristics, can form high yields at the level of 11-17 t/ha of grain under the efficient use of irrigation water, mineral macro- and micronutrient fertilizers, rapidly get rid of moisture at the ripening stage, have high resistance against common diseases and insects.

\section{SUMMARY}

Goal. To develop morpho-physiological and heterosis model of corn hybrids with FAO 150-600 for the irrigated conditions. Methods. General scientific, special genetic, field and laboratory and comparative methods of research were used. Results. The results of perennial researches on the development of morpho-physiological and heterosis models of corn hybrids of different groups of ripeness in the conditions of irrigation are presented. The main parameters of corn hybrids models of different groups by FAO. The parameters of heterosis models and of the created lines with high combinatory ability, which are involved in the genotype of newly created hybrids of the early-ripening, middle-early, middle-ripening, middle-late and late-ripening groups of maturity are determined. The results of the reaction of new hybrids on the irrigation ways and irrigation regimes are provided. Conclusions. Morpho-physiological and heterosis models and created on their basis corn hybrids of FAO 150-600 for the irrigated conditions in the South of Ukraine with grain yield of 11-17 t/ha were developed. New innovative hybrids of corn with FAO of 150-600 for the irrigated conditions, which have a complex of economically valuable characteristics and can form high yields at irrigation (11-17 t/ha of grain) under the efficient use of irrigation water, mineral macro- and micronutrient fertilizers, rapidly getting rid of grain moisture at the stage of ripening, and highly resistant to the common diseases and insects, which is put into their genetic potential. 


\section{REFERENCES}

1. Мелик-Саркисов С. Щ. Биотехнология в аграрном секторе США: Экономика развития. М.: Всероссийский НИИ с.-х. биотехнологии PACXH, 2005. $288 \mathrm{c}$.

2. Федорук П. С., Федорук С. П., Миренков С. Н. Проблемы и перспективы производства продуктов питания для народонаселения планеты. Научные труды Краснодарского НИИСХ им. П.П. Лукьяненко. Майкоп: Адыгея, 1999. С. 3-15.

3. Nobel Lectures, Peace 1951-1970, Editor Frederick W. Haberman, Elsevier Publishing Company, Amsterdam, 1972 MLA style: «Norman Borlaug - Nobel Lecture: The Green Revolution, Peace, and Humanity». Nobelprize.org. Nobel Media AB 2013. Web. 9 Mar 2014. http://www.nobelprize.org/nobel_prizes/peace/laureates/1970/borlauglecture.html

4. Джей Форрестер. Мировая динамика / Пер. с англ. А.Ворощука, С.Пегова. М.: ООО «Издательство АСТ; СПб.: Terra Fantastica, 2003. $379 \mathrm{c}$.

5. Марфенин Н.Н. Устойчивое развитие человечества. М.: Изд-во МГУ, 2006. $612 \mathrm{c.}$

6. Капица С. П. Демографическая революция и будущее человечества. В мире науки. 2004. №4. С. 82-91.

7. United Nations Population Division, World Health Organization (WHO), Food and Agriculture Organization (FAO), International Monetary Fund (IMF), and World Bank. http://www.worldometers.info/worldpopulation/

8. Народонаселение. Организация Объединенных Наций http://www.un.org/ru/sections/issues-depth/population/ OOH

9. Food and Agriculture Organization of the United Nations http://www.fao.org/faostat/en/\#data/QC

10. United States Department of Agriculture. Foreign Agricultural Service. http://www.usda crop explorer: global crop production analysis

11. Созінов О. О. Нові рубежі в селекції рослин. Вісник аграрної науки. 2000. №12. С. 22-24.

12. Рив М. Генетика и наследственность. М.: Мир, 1987. С. 251276.

13. Munsch M. A., Stamp P., Christov N. K., Foueillassar X. M., Hüsken A., Camp K. H., Weider Ch. Grain Yield Increase and Pollen Containment by Plus-Hybrids Could Improve Acceptance of Transgenic Maize. Crop Science. 2010. Vol. 50, Iss. 3. P. 909-919. 
14. Vozhegova R. A., LavrinenkoYu. O., Hlushko T. V. Productivity of maize hybrids of different FAO groups depending on condition of irrigation and dosage of fertilizers in the southern steppe of Ukraine. Agricultural Science and Practice. 2014. Vol. 1. No. 3. P. 62-68.

15. Troyer A. F. Background of U.S. hybrid corn: II. Breeding, climate and food. Crop Science. 2004. Vol. 44, Iss. 2. P. 370-380.

16. Мустяца С. И., Мистрец С. И. Использование зародышевой плазмы гетерозисных групп БССС и Рейд Айодент в селекции скороспелой кукурузы. Кукуруза и сорго. 2007. №6. С. 8-12.

17. Домашнев П. П., Дзюбецкий Б. В., Костюченко В. И. Селекция кукурузы. М.: Агропромиздат, 1992. 204 с.

18. Ушкаренко В. А., Лазарев Н. Н., Голобородько С. П., Коковихин С. В. Дисперсионный и корреляционный анализ в растениеводстве и луговодстве. Москва: Изд-во РГАУ - МСХА имени К. А. Тимирязева, 2011. 336 с.

19. Дзюбецький Б. В., Черчель В. Ю. Сучасна зародкова плазма в програмі з селекції кукурудзи в Інституті зернового господарства УААН. Селекція і насінництво. Харків, 2002. № 86. С. 11-19.

20. Плоткін С. Я., Лазер П. Н., Йокич Д. Р. Еколого-генетична детермінація добової втрати вологи зерном при дозріванні у гібридів кукурудзи в умовах південного Степу. Таврійський науковий вісник. 2003. Вип. 26. С. 37-45.

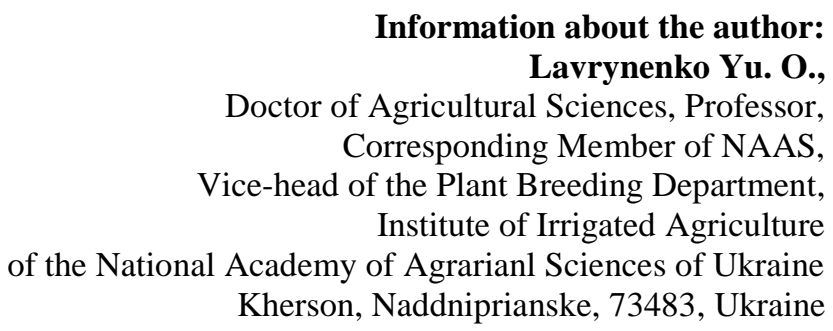


DOI https://doi.org/10.36059/978-966-397-154-4/120-134

\section{WATER AND ENERGY SAVING TECHNOLOGIES OF TILLAGE IN THE CONDITIONS OF SOUTHERN ARID AND DRY STEPPE OF UKRAINE}

\section{Maliarchuk M. P.}

\section{INTRODUCTION}

Basic tillage is one of the most important agrotechnical measures in crop cultivation technologies, which significantly affects the agrophysical properties, water and nutrient regimes of soil and forms the directions of soil-forming processes.

Tillage technologies influence differently on the individual layers of arable and sub-arable horizons. Unlike organic and mineral fertilizers, mechanic tillage does not add substance or energy to the soil, but causes significant changes in the ratio of the solid, liquid and gaseous phases of the soil system. It affects a variety of chemical, physico-chemical and biological processes, accelerating or suspending the rate of synthesis or decomposition of organic matter. Basic tillage plays role of the main factor in creating favorable physical conditions for soil fertility formation and remains one of the most important environmentally friendly measures for control of weeds, pests and diseases of crops.

Ways and depth of basic tillage for crops and crop rotation systems, which are formed in accordance with ecological and technological grouping of lands and specialization of farms, should be directed to the reduction of anthropogenic energy consumption, reduction of the tempo of mineralization of organic matter and prevention of the degradation processes.

At the present stage of development of agriculture, theoretical substantiation has been made with the subsequent practical application of two methods of basic tillage: plow and plowless, which can be deep, shallow or surface. Besides, each of the tillage methods has a significant number of techniques. So, the plowless tillage can be subsurface, chisel, disk; plow tillage - ordinary, double-layer, deep-plowing and cultural plowing. However, the whole list of techniques comes down to two fundamentally different ways of the plow and plowless, because subsurface, chisel, minimal, zero, conservation ones are varieties of plowless tillage, which is such a tillage, when the arable layer does not rotate. 
Plow tillage has got a priority in agricultural production till nowadays. It is based on modern substantiation that the fertility of arable soil profile is differentiated by the layers: the top layer is more fertile than the bottom one. Agricultural systems in their development have long been based on the use of plows with shelves of various modifications. However, the leading scientists in the field of agriculture do not consider such tillage as having no alternative. The basic requirements for plowing - to create in the soil the conditions, which are necessary for the development of crops; however, it should be carried out as rarely as possible, not more than once or twice per rotation, depending on the number of fields in rotation, since it requires significant costs, whatever perfect tools are used to perform it. Besides, plowing involves some destruction of the soil structure by the action of the plow working bodies and the pressure of the tractor's weight ${ }^{1}$. In the history of the development of views on soil tillage, the advantages of shallow and surface cultivation have occasionally been noted.

The researchers of the Odesa Scientific Station of NAAS, located in the Odesa region, consider that it is necessary to significantly increase the area of non-plowing tillage in the perspective, as it does not reduce the yield of crops, but also protects the soil from erosion and over-compaction, slows down the process of mineralization of humus, increases the productivity of labor, resolves the problem of weed control through the use of highly efficient herbicides, enhances the culture of agriculture, and saves fuel and lubricants ${ }^{2}$.

In the south of Ukraine, plowless tillage with the use of soil-cultivating tools with chisel-type working bodies, as well as the use of seeders for sowing into the non-processed soil, deserves attention. The advantage of plowless tillage for winter wheat, barley and rye is approved by the data of the Askania State Agricultural Research Station of the Institute of Irrigated Agriculture of NAAS ${ }^{3}$.

Plowless tillage is more and more widespread in production every year, and its effect is being determined, first of all, by the crop yield, increased labor productivity and reduced non-renewable energy expenditures.

During the recent years, the NAAS scientific institutions functioning in the Steppe zone have accumulated significant experimental material on the

${ }^{1}$ Гудзь В. П., Примак І. Д. та ін.Адаптивні системи землеробства: підручник. К.: Центр учбової літератури, 2007. 334 с. $125 \mathrm{c}$.

Щербак И. Е. Почвозащитная обработка полей в южных районах. М.: Колос, 1974.

${ }^{3}$ Малярчук М. П. Вплив грунтозахисних систем обробітку в сівозміні на родючість грунту, забур'яненість посівів та продуктивність сільськогосподарських культур. Зроиуване землеробство: міжвідомчий тематичний науковий збірник. 1992. Вип. 37. C. 13-19. 
use of a plowless method of basic tillage, while scientific data on its impact on the soil are contradictory and indicate not only a positive but also a negative impact on physical, chemical, biological and phytosanitary condition. On the one hand, this method of tillage slightly improves the water regime of the soil and its erosion resistance, and on the other, an increase in the weediness of crops and the number of diseases and pests is observed ${ }^{4}$.

Considering that the soil cover of the zone is represented by ordinary and southern chernozem, agrophysical properties of which are optimal for most crops even in the equilibrium, including root-crops, as well as dark-chestnut of varying degrees of alkalination, meadow-chestnut and meadowchernozem soils, which are glei, are confined to the closed wetlands, agrophysical properties of which are marginal for crops, the only approach to the choice of method and depth of basic tillage cannot be applied ${ }^{5}$.

The basic tillage of each soil in the Steppe zone should be directed to the accumulation and preservation of soil moisture, creation of favorable conditions of mineral nutrition of plants, preservation and increase of soil fertility and improvement of phytosanitary and ameliorative state in agrocenoses $^{6,7}$.

In the conditions of Southern arid and dry-steppe soil ecological zones of southern Ukraine, moisture is the main factor that limits the obtaining of high yields. Therefore, the accumulation and conservation of moisture in the soil and its economical use is a priority of modern agriculture. The main role in this belongs to the basic and pre-sowing tillage.

Tillage obtained particularly important value in the soil moisture accumulation in recent decades, due to the increasing aridity of the climate in the region. Over the last forty years, the average annual temperature in Southern Steppe has increased by $2^{\circ} \mathrm{C}$, including in March and April by 1.3 and $1.6^{\circ} \mathrm{C}$, and in September and October by $2.9,1.8^{\circ} \mathrm{C}$, respectively ${ }^{8}$.

\footnotetext{
${ }^{4}$ Меліорація грунтів (систематика, перспективи, інновації): колективна монографія; за ред. С.А. Балюка, І.М. Ромащенка, Р.С. Трускавецького. Херсон: Грінь Д.С., 2015. 668 с.

5 Малярчук М. П. Система обробітку грунту. Наукові основи охорони та раціонального використання зрошуваних земель України. Київ: Аграрна наука, 2009. C. 299-313.

${ }^{6}$ Камінський В. Ф., Сайко В. Ф. Стратегія розвитку адаптивних систем землеробства і агротехнологій в Україні. Адаптивні системи землеробства і сучасні агротехнології основа раціонального землекористування, збереження і відтворення родючості грунтів. К.: ВП «Едельвейс», 2013. С. 5-24.

7 Гордієнко В. П., Грабак Н. Х. Малієнко А. М. Прогресивні системи обробітку грунту; за ред. В.П. Гордієнка. Сімферополь, 1998. 272 с.

${ }_{8}$ Kovalenko A. Increasing aridity climate of southern steppe of Ukraine. Its effects and remedies, 3rd UNCCD Scicntific Conference, 9-12 March 2015, Cancun. Mexico: Book of Abstracts, 2015. P. 293-294.
} 
The annual rainfall during this period decreased slightly, but not as significantly as in the spring and autumn period. Thus, in March, September and October their number decreased by two times ${ }^{9}$. This complicates both basic tillage and pre-sowing tillage conduction.

In the autumn during the last years, the soil is very dry and not it is not always possible to conduct qualitative tillage. The cultivated soil under such conditions is very clayy, crumbles badly, the post-harvest residues and weeds are not incorporated qualitatively. This often causes the delay of tillage time to December and even January. Under such conditions, the period from plowing to the beginning of spring-field work is greatly reduced, which does not allow the soil to create the bumpy structure necessary for the sowing of spring crops in the short term. In addition, the soil does not have time to compact and remains loose, which leads to the formation of deep tracks on the passes of tractors and does not create sufficient contact with the seeds of spring crops during sowing.

The requirements of modern Steppe agriculture are the most fully compliant with the system of differentiated tillage methods. It should be adapted to the zonal conditions, dynamic, energy- and moisture-saving and environmental protection, to take into account the phytosanitary conditions of the fields and the genetically determined potential of crop productivity and to ensure the effective soil fertility.

Deep $(25-30 \mathrm{~cm})$ tillage is of particular importance on heavy by the mechanical composition, alkaline, structureless and compaction-prone soils. Row crops (root-crops, corn), perennial herbs and legumes respond positively to deep loosening. The need for deep tillage is also determined by the need to eliminate root weeds, incorporate organic fertilizers and residues that remain on the field. The duration of its effects in rotation increases on well-humus chernozems and decreases with the use of heavy machinery.

Shallow $(8-16 \mathrm{~cm})$ and surface $(6-8 \mathrm{~cm})$ tillage is advisable to carry out for winter wheat, spring cereals on the cultivated flat areas, as well as soils of light and medium granulometric composition that are well saturated with carbonates, chernozems with high (more than 40\%) content of waterresistant aggregates. The efficiency of minimum tillage increases with shallow groundwater layer $(1-2.5 \mathrm{~m})$ and the presence of perennial legumes in the crop rotation.

Zero tillage is promising under the sufficient humidification on fertile light soils (humus content of more than $4 \%$ ) after corn, sunflower, sorghum,

${ }^{9}$ Вожегова Р. А., Коваленко А. М., Малярчук М. П. та ін. Формування систем обробітку грунту в короткоротаційних сівозмінах: науково-методичні рекомендації. Херсон: ВЦ І33, 2015. 18 с. 
beets under early spring, at winter wheat cultivation after non-fallow forecrops, as well as post-harvest and post-mowing crops. Direct sowing drills work qualitatively on shallow and surface-tilled agricultural backgrounds.

Almost all of these systems, in addition to sowing in pre-tilled soil, must be subjected to stubbling before basic tillage.

Timely stubbling eases basic tillage and improves the quality of its conduction, prevents the growth of weeds and drying of the lower soil layers, improves the living conditions for microorganisms and accelerates the decomposition of plant residues.

Stubbling contributes to the destruction of the seeds fall, causing the death of stem pests and pathogens of plants whose life cycle is related to the topsoil or stubble (root rot, rust, powdery mildew).

In the zone of manifestation of wind and water erosion good results are provided by heavy universal cultivators manufactured by TOV Krasnyansk SP Agromash of the types KV-3.0 N, KV-4.0 N, KV-6.0 N, and disc-chisel harrows BDC-5, BDC-6, BDC-7. They provide complete cutting of perennial weeds and leave on the surface $60-70 \%$ of post-harvest residues that mulch the soil and in 3-5 times reduce the erosion action of rain and prevent crust formation. This reduces the risk of soil erosion and loss of water from runoff.

Depth and number of stubbling depends on weediness and mass of postharvest residues. In the case of weediness with mainly annual weeds, disc plowing on the depth of $6-8 \mathrm{~cm}$ is used. In the fields where there is a lot of sow thistle and other root-weeds, a two-time multi-depth stubbling is effective: first on the depth of 6-8 cm, the second on a depth of $10-12 \mathrm{~cm}$ with disk tools BDLP-8, BDLP-4. Owing to the small width of cut of working bodies, the optimum angle of breaking and equipment with rollers they provide high-quality cutting of perennials and loosening of the soil surface. After the stubble forecrops, when all the straw is left in the field, and after the tillage of coarsestem (corn, sorghum, sunflower) crops whose post-harvest residues requires long time to be mineralized in the soil, the quality of stubbling is better at the use of heavy disk harrows BDVP-4.2-0.1, BDVP-3.0-0.1 equipped with the working bodies of disk and chisel type and rollers. At the use of these combined tillage machines for one pass of the aggregate, the qualitative preparation of the soil for sowing of winter cereals is ensured.

\section{Basic tillage of plowland}

In the enterprises of the irrigated zone of Ukraine, which specialize in corn cultivation, soybean and sunflower for industrial processing in short 
crop rotations using all the by-products (leaf-stem mass) for fertilizer, plowing is currently one of the most common methods of tillage. Preference should be given to high-clearance reversible plows with variable cut widths that provide smooth plowing on a depth of 20 to $30 \mathrm{~cm}$ without primary grinding of plant residues. Owing to the smoothed surface on the background of smooth plowing, technological operations related to soil preparation and sowing in the spring are performed better than usual.

The advantage of subsurface tillage in comparison to plowing can be observed in the conservation of moisture during the years with low rainfall during autumn and winter and with an active wind regime in the spring. It is especially effective in improving the physicochemical properties of the subsurface layer of medium- and highly-washed out soils, at the cultivation of solonetz. It is suitable for the long-term use in field crop rotations.

One of the types of subsurface tillage is loosening of soil to a depth of 12 to $20 \mathrm{~cm}$ by flat-cutting tools of different types (KR-4.5; AKS-5.4; KPS-5), at the use of which more than a half of the post-harvest residues remains on the soil surface. High efficiency of plowless tillage is evident on chernozems with light and medium mechanical composition and on the fields that are exposed to wind erosion.

It is impractical to use the tools with flat-cutters after corn for grain, sorghum crops and sunflower, which are discharged under spring cereals, as well as on the compacted and dry soils. In this case, there is an unsatisfactory crumbling of the chunk, accumulation of dust on the surface of the soil, decrease in the water permeability of the soil.

The rapid development of economical agrotechnology, due to the economic and energy factors and limited labor resources, has led to widespread use in the production conditions of shallow tillage, which is proved to be the most suitable for cultivation of early cereals after row crops (corn, sunflower, sugar-beet) on the well-cultivated fields.

At the same time, as the results of scientific research and practical experience testify, its effectiveness is reduced on saline chestnut soils and heavy by the mechanical composition chernozem soils of low humus content, as well as on the slopes of more than $2^{\circ} \mathrm{C}$. The shallowly loosened eroded soil is quickly compacted and overcrusted, but at the same time it is not able to accumulate moisture from rainfall and can be washed away with water from the bottom of the furrow to the entire depth of cultivation ${ }^{10}$.

\footnotetext{
${ }^{10}$ Вожегова Р. А., Коваленко А. М. Зміни клімату в південному регіоні та напрями адаптації землеробства до них. Посібник украӥнського хлібороба "Адаптивне землеробство». Київ: ТОВ «АКАДЕМПРЕС», 2013. Том 1. С. 189-190.
} 
At the shallow tillage, the phytosanitary condition of the crops is deteriorating, the volume of pesticide use is increasing, there is a problem of economic feasibility and environmental safety of production.

Shallow tillage is often the reason for the unstable water regime of the soil. The density and hardness of the underlying surface layer significantly limits the moisture accumulation here in the autumn and winter. According to the perennial data of the Institute of Grain Farming, the use of shallow disc tillage for the row crops leads to the accumulation of less productive moisture in the deep layers of the soil and to a decrease in corn yield by 0.44 , sunflower by 0.28 tha in comparison to the chisel loosening.

A persistent tendency to the decrease of the yield of early spring cereals with shallow winter tillage is observed in the fields with a large amount (more than $5 \mathrm{t} / \mathrm{ha}$ ) of uncrispy post-harvest residues of the forecrop. On this agrophone, the quality of pre-sowing cultivation and sowing with drills SZ-3.6 A, SZ-5.4 equipped with disk coulters is significantly deteriorated. The risks associated with the wrapping of all the by-products of the crop directly into the topsoil are partially offset by the use of special shredders of the leaf-stem mass and of the Amazon-Horsch-Agro-Union type sowing and tillage complexes. According to the data of the Institute of Irrigated Agriculture of NAAS, the influence of the basic tillage system in Southern Steppe on moisture accumulation in the autumn and winter has slightly changed in recent years. It was previously recognized that the greatest amount of moisture during this period in southern region accumulates at deep plowing. But this is not always the case now. Studies of different tillage of winter wheat forecrops indicate that, as before, the advantage of moisture accumulation in the autumn period remains in deep plowing.

However, this advantage is much less than 20-25 years ago. In addition, during the autumn and winter period, productive moisture reserves are leveled for all tillage options. With regard to basic tillage under the spring crops, there were no significant changes in soil moisture accumulation detected in different ways of basic tillage under the influence of climate change. As before, the reserves of productive moisture in the meter layer of soil are almost independent on the way and depth of the basic tillage.

\section{Tillage for the spring crops}

In the Steppe zone, the restoration of moisture reserves is mainly through the fall-winter precipitation. The insufficient level of their assimilation (30$40 \%$ ) is largely caused by poor basic tillage of the soil, in particular, its excessive lumpiness, which increases the processes of evaporation, blowing out and freezing of water. The likelihood of the formation of a lumpy surface 
is significantly increased by conducting a deep winter tillage without primarily stubbling, especially in the fields with heavy machinery and in drought conditions ${ }^{11}$.

Zero tillage. For the last time, so-called zero tillage, or sowing into nontilled soil, has become widespread. It provides a radical solution to the problem of conservation of energy resources and soil protection through the introduction of zero crop cultivation technologies in agrarian production, based on the complete disawowal of mechanical tillage with the exception of the operation of seed bed preparation simultaneously with sowing by using special drills (Great Plains, Kinze, ATD-9.35, Sirius-10).

The studies of the Steppe scientific institutions testify that the efficiency of zero tillage is determined, first of all, by the soil and climatic conditions, the duration of its application and the tolerance of the crops. Its main advantages include high anti-erosion resistance and minimal fuel and labor costs, the drawbacks are significant dependence on chemicals and prices for the means of production.

On the background of the conventional tillage system, a one-time sowing in the previously untilled soil slightly changes the water-physical properties of the arable layer, however, the range of indicators is within the limits of biological optima and does not cause a negative reaction of crops. The possibility of chernozem to restore its optimal parameters is significantly diminished in cases of prolonged application of zero tillage and when rainfall does not ensure normal plant development.

In severely dry years on heavy by mechanical composition soils (physical clay content of more than $45 \%$ ), untilled soil is over-compacted in May-June to the critical level, capiillary ruture occurs later and at the smaller absolute value than on the plowland that leads to the significant increase (by $12-41 \mathrm{~mm}$ ) of unproductive losses of soil moisture, resulting in the difficulties of obtaining good seedlings of late spring crops in hot weather on zero dehydrated agrophones.

The risks associated with direct sowing of crops are increased in the presence of perennial weeds and on dark-chestnut and chestnut soils of the dry and very dry Steppe under the leaving a large number of rough plant residues in the field.

Our studies conducted at the Askania Research Station of the Institute of Irrigated Agriculture testify that the use of zero tillage for spring crops

11 Тимошенко Г. 3., Коваленко А. М., Новохижній М. В. Вплив різних способів основного обробітку грунту на урожайність ячменю ярого. Зрошуване землеробство: міжвідомчий тематичний науковий збірник. Херсон: Грінь Д.С., 2015. Вип. 64. C. 114-116. 
increases the bulk density of soil in the layer of $0-40 \mathrm{~cm}$ by $0.08-0.17 \mathrm{~g} / \mathrm{cm}^{3}$, and on winter crops by $0.04-0.11 \mathrm{~g} / \mathrm{cm}^{3}$ in comparison to deep tillage. Soil permeability is reduced by $17-23 \%$.

The yields of spring crops of the ordinary row sowing (spring wheat, peas, mustard) are reduced by $15.5-31.7 \%$ in comparison to deep tillage and by $11.1-27.7 \%$ in comparison to shallow tillage. The yield of row crops (sorghum) decreased by $51.9 \%$ in comparison to deep tillage and by $44.5 \%$ in comparison to shallow tillage.

Soil slotting. Slotting through the deep (up to $60 \mathrm{~cm}$ ) soil cutting is used mainly on slope lands to regulate the flow of meltwater and enhance the accumulation of precipitation. On dark-chestnut and chestnut soils in the area of irrigation systems of Ukraine, slotting significantly improves the use of irrigation water and moisture supply of field crops, increases the productivity of irrigated crop rotation by dry matter output by $0.5-0.7 \mathrm{t} / \mathrm{ha}$, or $17-20 \%$. Slotting is effective on crops of winter and perennial herbs, soils of heavy mechanical composition with low humus content, which are prone to fast over-compaction. It is carried out by deep-loosening machines CG 40, CG 40-01, CG 40-02, CG 5.5 produced by TOV «Krasnyansk SP» Agromash».

On the eroded lands, slotting of perennial herbs is particularly effective, where the soil is most compacted and plants often lack moisture and oxygen. The agricultural measure is carried out in the fields occupied by the herbs of the second and third years of use before freezing of the soil.

Boundary slotting in the system of early fallow has a priority after sunflower and corn that have been grown at the ridges. Here, it provides an additional accumulation of $250-300 \mathrm{~m}^{3} /$ ha of melted water, greater depth of soil wetting and, as a result, increased winter wheat yields in the area of slotting.

Soil mulching. The main task of mulching tillage is to create a soilprotective surface from the plant residues of the previous or intermediate crop to protect the soil from deflation and washing out, additional accumulation of snow, reduction of water runoff and unproductive evaporation. The protective and moisture-saving effect of the agrophone depends on the amount, physical properties, orientation, aerodynamic rigidity and height of the plant residues, as well as the power, porosity and uniformity of the mulching layer. Significantly reduces erosion and moisture loss evenly covering of $60-80 \%$ of the field area with the crop residues of the forecrop, which, in terms of grain equivalent of cereals, is about 2-4 t/ha.

Soil mulching with post-harvest residues in the Steppe plays a particularly important role in the cultivation of row crops and keeping pure 
fallow, the surface of which is the least protected from the effects of destructive factors. It is possible to halt the erosion and degradation of the chernozems on the plains and slopes by transition from the classical fallows to the early ones, since the latter are completely protected from blowing in the winter and spring, and the flow of meltwater here does not cause significant soil erosion.

The resistance of early fallow to the erosion of summer rainfall increases with the presence on the surface of more than $2.5 \mathrm{t} / \mathrm{ha}$ of plant substrate, the conservation of which is achieved by transferring the terms of basic tillage to May and carrying it with a plowless tools at a depth of loosening $12-16 \mathrm{~cm}$, reducing the number of technological operations, replacement of cultivations with harrowing, application of herbicides. For fallow mulching it is advisable to use coarse post-harvest residues of corn, sorghum, Sudanese grass, which are partially incorporated, mixed with the topsoil and have a long period of rotting. In this case, the surface becomes rough and absorbs water better, at the same time, it diminishes the processes of crust formation, siltation and blocking of pores.

At the cultivation of row crops, which in the Steppe are mainly placed in after stubble forecrops, a high degree of surface coverage with post-harvest residues in the cold season ensures winter tillage of the soil.

For the time of sowing corn and sunflower by using the elements of conventional technology (moisture covering, two pre-sowing cultivations) the number of post-harvest residues is reduced to the critical mark of 80$100 \mathrm{pcs} / \mathrm{m}^{2}$ (0.7-0.9 t/ha), and projectivity does not exceed $20-25 \%$. Such agrophone loses its anti-erosion ability even when the average intensity of the rain falls by a layer of $25-30 \mathrm{~mm}$ and the wind speed is $12-15 \mathrm{~m} / \mathrm{min}$.

The improvement of moisture-saving and soil-protective efficiency of mulching at the cultivation of row crops is mainly achieved by leaving all or part of the by-products within the field, reducing the number of mechanical tillage and using technical means that incorporate less of the crop residues in the soil: combined aggregates and drills for sowing in previously non-tilled soil.

Pre-sowing tillage. Creation of reliable anti-erosion and moisture-saving agrophone during the pre-sowing period is achieved by minimizing tillage due to the exclusion of individual operations, reducing the depth of loosening, combination of technological operations, the use of wide-cut and combined aggregates.

On the leveled fields after stubble forecrops, which were processed with heavy disk harrows in the autumn, it is not advisable to carry out early spring harrowing. In the cultivation of early spring cereals and legumes in such areas, it is desirable to use cultivators K-4.3, K-7.3 K-9.3, K-11, which 
in the one pass carries out the preparation of the seed bed, mulching, leveling and compaction of the cultivated layer of the soil.

On the cloddy plowland, where the convection-diffuse process of moisture loss prevails, it is covered in the first days of spring-field work by heavy tooth or wide-cut combined aggregates AK-6, AK-7, which in the one pass level the surface of the soil, perform loosening to $4-16 \mathrm{~cm}$ depth, and compacts the treated layer.

The studies of the Steppe scientific institutions testify that, due to the high crop cultivation and improved basic tillage on chernozem under corn and sunflower, it is possible to come to one pre-sowing cultivation of the soil. In addition to the economic cost, it allows you to retain moisture and obtain good seedlings.

Extremely deep tillage in the spring under spring crops increases the porosity of the soil, which enhances its drying, especially in hot windy weather. Therefore, the depth of pre-sowing cultivation must in all cases correspond to the depth of seed incorporation. Violation of this agrotechnical requirement leads to the placement of seeds in the semi-dry layer of soil and thinning of the seedlings.

\section{Tillage for winter crops}

Classical fallow. Фe epy proper preparation, classical fallow is equaled to irrigation, guarantees 6-8 t/ha of high-quality winter wheat grain and has a positive effect on the growth and development of subsequent crops. However, it remains the most vulnerable field of crop rotation, where it is extremely difficult to slow down soil erosion.

Among the approved tools for soil-protective basic tillage of classical fallow, the best ones are heavy chisel cultivators, which provide high antierosion efficiency and high quality of fertilizers incorporation.

The introduction of earlyfallow is a radical measure to counteract the destruction and degradation of soils. By the amount of accumulated moisture in the cold season, the untreated agrophone (early fallow) does not cede to classical fallow in autumn, but is not susceptible to erosion even at critical wind and runoff speeds. With increased buffer, holding and clogging capacity, the soil washes out here were 1.6-4.1 t/ha, which is 5-11 times less than under plowing $(18.3 \mathrm{t} / \mathrm{ha})$.

The technology of basic tillage of early fallow after sunflower, corn, Sudanese grass, sorghum is based on the complete exclusion of autumn tillage, background stubbling at the beginning of spring field work and the subsequent (3-4 weeks) loosening of the soil by heavy chisel cultivators to a depth of 16-18 cm depending on the relief, the weather comditions, the mass 
of plant residues and the weediness of the field. With a high load capacity, the early fallow preparation process scheme may include late-autumn soil slotting by the band scheme of 2x140 cm every 4-6 $\mathrm{m}^{12}$.

Care for classical fallow. It is based on the principles of agrienvironment and economic feasibility, with priority being given in the first half of the summer to the measures directed to clearing the fallow from weeds, and in the second - to focusing on the prevention of the excessive loss of soil moisture.

In all cases, the first shallow $(8-10 \mathrm{~cm})$ cultivation of the fallow field is less effective than the deep one $(12-14 \mathrm{~cm})$, at which perennial weeds are destroyed, no compacted layer is created, the soil resists erosion better and absorbs moisture well. Among the tested soil tillage tools, when performing the first deep cultivation on the plowless backgrounds, the advantageous are anti-erosion cultivators KEE-3.8, KPE-6H and combined aggregates of the type KP-4.5, equipped with flat-cutting paws and rotary disc consoles, on the plowlands - modified fallow cultivators KPS-4, the construction of which limits the vibrations of the risers in the horizontal plane and provides loosening of the soil to a predetermined depth and qualitative cutting of weeds.

For the surface tillage of fallow fields the cultivators equipped with working bodies of flat-cutting type, which prevent the excessive destruction of mulch and mixing of dry and moist soil layers, save moisture at the depth of seed wrapping, are used. Flexi-Coyle ZBR-24 spring and tooth harrows are effective on the plowless backgrounds. To avoid over-compaction of the arable layer, especially in the spring, the wide-cut aggregates with radially or twin tires with low specific pressure on the soil should be used for the care of the fallow field.

Green fallow. Taking into account the differences of the fallow crops, the specificity of the Steppe relief and climate, the system of tillage of the green fallow is subordinated to the solution of two main tasks: creation of an erosion-resistant surface of the field in the post-harvest period and prerequisites for the guaranteed obtaining of full-value seedlings of winter crops.

The main importance in the preparation of the green fallow (after winter, grain mixtures for green manure) has timeliness, consistency and regularity of technological operations: immediate stubbling of stubble with disc

\footnotetext{
${ }^{12}$ Малярчук М. П., Вожегова Р. А., Марковська О. С. Формування систем основного обробітку грунту в агробіоценозах на меліорованих землях південної посушливої та сухо степової грунтово-екологічних підзон України: навчальний посібник. Херсон: Айлант, 2012. $180 \mathrm{c}$.
} 
harrows on $8-10 \mathrm{~cm}$, tillage with combined aggregates of the type KR-4.5, KRG-5, AKS-5.4 on 10-12 cm, loosening of the soil with fallow cultivators on the depth of seed wrapping.

Perennial herbs. Preparation of the field for winter wheat after perennial herbs on the basis of moldboard plowing in dry years leads to excessive lumpiness of soil, which causes significant losses of moisture, inhibition of microbiological processes, deterioration of the quality of sowing operations.

Resource- and water-saving technology of soil tillage after perennial herbs involves loosening with heavy disc harrows on the depth of 10-12 cm followed (with a gap of 2-3 days) by shallow $(14-16 \mathrm{~cm}$ ) one. At the observation of agrotechnical standards such a scheme of tillage excludes the possibility of regrowth of perennial herbs and guarantees conservation of residual moisture and its accumulation from summer rainfall.

Pea. The bulk density of arable soil layer at the time of harvesting of the leguminous crop mostly exceeds the optimally permissible index of $1.30 \mathrm{~g} / \mathrm{cm} 3$ that leaves out the possibility of qualitative plowing of the field. Therefore, after peas, in the presence of sufficient moisture reserves, the soil is cultivated by light disc harrows of the BDLP-8 and BDLP-10 type. Subsequent formation of optimal agro-physical parameters of the sowing layer, weed and seed fall destruction is achieved by the conduction of cultivations with combined multioperative cultivators with rollers.

At the placement of winter crops after row crops of corn, sunflower, it is necessary to perform mulching tillage with heavy disj harrows on the day of harvesting, which includes grinding of the post-harvest residues and partially incorporation of them with heavy disc harrows and pre-sowing cultivation on the depth of seed wrapping.

\section{CONCLUSIONS}

In Southern arid and Dry Steppe soil-ecological zones of Ukraine on the plain-lands of first technological group it is advisable to introduce grainfallow-row systems of agriculture with corresponding structure of sown areas and crop rotations, and implement systems of differentiated soil tillage at which surface and shallow disk tillage under cereal crops during the rotation is interchanged with deep plowing, chisel loosening or slotting once per the rotation of 4-5-foeld crop rotations.

\section{SUMMARY}

Experimental materials on the determination of the use efficiency of different ways and depths of basic tillage in the arid conditions of Southern 
arid and dry Steppe soil-ecological zones of Ukraine at the cultivation of winter wheat after different forecrops are presented.

Methods: field, analytical, estimation and comparison, mathermatical statistics. Results. Experimental studies testify that for the years of the study winter wheat yields ranged from 2.70 to 4.90 t/ha depending on the studied factors. Comparing the crop yields by the ways of tillage, certain dependence was found. Thus, at plowing on the depth of $14-16 \mathrm{~cm}$ in a system of differentiated plowing tillage without fertilizer, the yield was 3.15 $\mathrm{t} / \mathrm{ha}$, and at the chisel tillage on the same depth in the system of plowless loosening $-3.01 \mathrm{t} / \mathrm{ha}$ or by $4.6 \%$ lower. Shallow disk loosening under the long-term application in the crop rotation resulted in a decrease in yields by $14.3 \%$ and $11.5 \%$, respectively, in comparison to differententiated systems. The most energy-efficient variant is an experiment with mineral fertilizers application. Conclusions. On the dark-chestnut middle-loamy soils of the South of Ukraine in the crop rotations it is advisable to apply systems of differentiated tillage when surface and shallow disk tillage for winter wheat and barley during the rotation is changed by deep plowing or chisel loosening.

\section{REFERENCES}

1. Гудзь В. П., Примак І. Д. та ін. Адаптивні системи землеробства: підручник. К.: Центр учбової літератури, 2007. 334 с.

2. Щербак И. Е. Почвозащитная обработка полей в южных районах. М.: Колос, 1974. 125 с.

3. Малярчук М. П. Вплив грунтозахисних систем обробітку в сівозміні на родючість грунту, забур'яненість посівів та продуктивність сільськогосподарських культур. Зрошуване землеробство: міжвідомчий тематичний науковий збірник. 1992. Вип. 37. С. 13-19.

4. Меліорація грунтів (систематика, перспективи, інновації): колективна монографія; за ред. С.А. Балюка, І.М. Ромащенка, Р.С. Трускавецького. Херсон: Грінь Д.С., 2015. 668 с.

5. Малярчук М. П. Система обробітку грунту. Наукові основи охорони та раціонального використання зрошуваних земель України. Київ: Аграрна наука, 2009. С. 299-313.

6. Камінський В. Ф., Сайко В. Ф. Стратегія розвитку адаптивних систем землеробства і агротехнологій в Україні. Адаптивні системи землеробства і сучасні агротехнології - основа раціонального землекористування, збереження і відтворення родючості грунтів. К.: ВП «Едельвейс», 2013. С. 5-24. 
7. Гордієнко В. П., Грабак Н. Х. Малієнко А. М. Прогресивні системи обробітку грунту; за ред. В.П. Гордієнка. Сімферополь, 1998. $272 \mathrm{c}$.

8. Kovalenko A. Increasing aridity climate of southern steppe of Ukraine. Its effects and remedies, 3rd UNCCD Scicntific Conference, 9-12 March 2015, Cancun. Mexico: Book of Abstracts, 2015. P. 293-294.

9. Вожегова Р. А., Коваленко А. М. та ін. Формування систем обробітку грунту в короткоротаційних сівозмінах: науково-методичні рекомендації. Херсон: ВЦ І33, 2015. 18 с.

10. Вожегова Р. А., Коваленко А. М. Зміни клімату в південному регіоні та напрями адаптації землеробства до них. Посібник украӥнського хлібороба «Адаптивне землеробство». Київ: ТОВ «АКАДЕМПРЕС», 2013. Том 1. С. 189-190.

11. Тимошенко Г. З., Коваленко А. М., Новохижній М. В. Вплив різних способів основного обробітку грунту на урожайність ячменю ярого. Зрошуване землеробство: міжвідомчий тематичний науковий збірник. Херсон: Грінь Д.С., 2015. Вип. 64. С. 114-116.

12. Малярчук М. П., Вожегова Р. А., Марковська О. С. Формування систем основного обробітку грунту в агробіоценозах на меліорованих землях південної посушливої та сухо степової грунтовоекологічних підзон України: навчальний посібник. Херсон: Айлант, 2012. $180 \mathrm{c}$.

Information about the author: Maliarchuk M. P., Doctor of Agricultural Science, Senior Researcher, Chief Researcher, Institute of Irrigated Agriculture of the National Academy of Agrarian Sciences of Ukraine Kherson, Naddniprianske, 73483, Ukraine 


\section{INNOVATIVE ELEMENTS OF CULTIVATION TECHNOLOGY OF CORN HYBRIDS OF DIFFERENT FAO GROUPS IN THE CONDITIONS OF IRRIGATION}

\section{Marchenko T. Yu.}

\section{INTRODUCTION}

Domestic scientific experience has shown that by potential of productivity of grain and green mass, forage and energy value corn is actually uncompetitive and irreplaceable in forage rations for cattle. But the methods of technological operations at present do not fully promote the realization of the yield potential of new morpho-biotypes of this crop, which is connected with insufficient compliance of agro-technologies to morphobiological features of a hybrid ${ }^{1}$.

The increase in yield of corn can be achieved through plant breeding and seed production and use of innovative hybrids. Herewith, according to many scientists, the use of micro-fertilizers and bio preparations remains an important component of agricultural intensification ${ }^{2,3,4}$.

At present, many chemical compounds have been synthesized, with the help of which it is possible to actively influence the biochemical processes in plants. Due to the small norms of application and biological origin, micronutrient fertilizers and plant growth regulators belong to the safest preparations. The issue of wide application of biologically active preparations in agriculture is paid considerable attention in the most economically developed countries $5,6,7,8,9,10,11$.

1 Лавриненко Ю. О., Нужна М. В., Боденко Н. А. Моделі гібридів кукурудзи FАO 150-490 для умов зрошення. Plant Varieties Studying and Protection. 2018. T. 14, № 1. C. 58-64. doi:10.21498/2518-1017.14.1.2018.126508.

2 Токмакова Л. М., Трепан А. О., Шевченко Л. А. Ефективність фосфорного живлення рослин кукурудзи за дії поліміксобактерину. Вісник Полтавської держсавної агарної академії. 2019. № 1. С. 73-80. doi:10.31210/visnyk2019.01.09

${ }^{3}$ Lavrynenko Y. O., Hozh O. A., Vozhegova R. A. Productivity of corn hybrids of different FAO groups depending on micro-fertilizers and growth stimulants under irrigation in the south of Ukraine. Agricultural Science and practice. 2016. No. 1. P. 55-60.

${ }^{4}$ Mason S., Kmail Z., Galusha T., Jukić Ž. Path analysis of drought tolerant corn hybrid yield and yield components across planting dates. Journal of Central European Agriculture. 2019. 20(1). P. 194-207. https://doi.org//10.5513/JCEA01/20.1.2106

5 Milander J., Jukić Ž., Mason S. Hybrid maturity influence on corn yield and yield component response to plant population in Croatia and Nebraska. Cereal Research Communications. 2017. Vol. 45, Iss. 2. P. 326-335. https://doi.org/10.1556/0806.45.2017.015 
The maximum yield of high quality corn grain is formed under condition of the optimal ratio of all structural elements - the weight of 1000 seeds, the number of grain rows in the cob, the number of grain in a row and the number of grain per cob, length and diameter of the cob. Under the insufficient development of one structural element, the yield can be compensated at the expense of other constituents. Since the individual elements of the structure are formed at different stages of organogenesis, unequal conditions for their successful development are required ${ }^{12}$.

The formation of corn plant productivity is a complicated process, which includes a number of decisive genetic factors, a number of abiotic, biotic and anthropogenic factors ${ }^{13}$. The introduction of high-yielding hybrids and effective cultivation technologies can provide a qualitatively new level of corn yield. In the recent years, the main task of its cultivation technologies remains in reduction of the gap between the actual and genetic productivity of plants ${ }^{14}$.

The aim of the research is to determine the manifestation of the plant structure indexes of modern corn hybrids of different FAO groups and find out their relationship with the grain yield under the cultivation at drip irrigation in the conditions of Southern Steppe of Ukraine. To establish the

${ }^{6}$ Irmak S., Djaman K. Effects of planting date and density on plant growth, yield, evapotranspiration, and water productivity of subsurface drip-irrigated and rainfed maize. Transactions of the ASABE. 2016. 59(5). P. 1235-1256. doi: 10.13031/trans. 59.11169

7 Котченко М. В., Кірсанова Г. В., Пугач А. М., Пугач А. В. Продуктивність різностиглих гібридів кукурудзи в умовах Північного Степу України. Вісник Полтавської державної аграрної академії. 2016. № 4. С. 27-30. doi.org/10.31210/visnyk2016.04.04

${ }^{8}$ Calvino P. A., Andradeb F. A., Sadrasb V. O. Maize yield as affected by water availability, soil depth, and crop managemen. Agronomy Journal. 2003. No. 95. 275-281.

${ }^{9}$ Troyer A. F., Background U. S. Hybrid Corn II. Crop Science. 2004. Vol. 44. No. 2, P. 370-380. doi:10.2135/cropsci 2004.3700

10 Лавриненко Ю. О., Михайленко І. В., Хоменко Т. М. Біометричні показники гібридів кукурудзи різних груп ФАО залежно від обробки мікродобривами за умов зрошення. Plant Varieties Studying and protection. 2019. Vol. 15, № 1. C. 71-79. doi.org/10.21498/2518-1017/15/1/2019/162486

${ }_{11}$ Лавриненко Ю. О., Вожегова Р. А., Гож О. А. Продуктивність гібридів кукурудзи різних груп ФАО залежно від стимуляторів росту та мікродобрив в умовах зрошення на півдні України. Вісник аграрної науки. 2016. № 7. С. 28-33.

${ }^{12}$ Гож А. А., Лавриненко Ю. А., Глушко Т. В., Лашина М. В. Агротехнологические аспекты формирования продуктивности гибридов кукурузы на орошаемых землях юга Украины. Современные энерго- и ресурсосберегающие, экологически устойчивые технологии и системы сельскохозяйственного производства. Рязань, 2014. № 11. С. 33-37.

${ }_{13}^{13}$ Сухому О. Г., Адаменко Д. М., Кравець І. С., Суханов С. В. Вплив застосування мікродобрив ТМ «Актив-харвест» на ріст, розвиток і врожайність рослин кукурудзи. Вісник Уманського національного університету садівництва. 2019. № 94(1). С. 156-164. doi.org/10.31395/2415-8240-2019-94-1-156-164

${ }_{14}^{14}$ Глушко Т. В., Войташенко Д. П. Урожайність та якість зерна кукурудзи під впливом біопрепаратів в умовах зрошення Південного Степу України. Зрошуване землеробство. 2013. № 59. С. 44-47. 
effect of micro-fertilizers on the figures of corn hybrids yields and to justify the agro-technical recommendations for the cultivation of high yields of the crop grain.

\section{Research materials and methods}

Field double-factor experiment was conducted during 2016 - 2018 on the basis of the Institute of Irrigated Agriculture, located in the South of the Steppe zone of Ukraine, namely on the right bank of the Dnipro River in Bilozerka District of Kherson region in the zone of Ingulets irrigation system array.

The experiment was settled down by using the method of randomized split plot design. The study was conducted in four replications. The sowing area of the plot was $30.0 \mathrm{~m}^{2}$, the estimated one $-20.0 \mathrm{~m}^{2}$. Factor A different by the groups of ripeness domestic hybrids of corn: DN Galateya (FAO 250), Skadovskyi (FAO 290), DN Demetra (FAO 300), Ingulskyi (FAO 350), DN Bereka (FAO 390), Chongar (FAO 420).

Factor B - treatment of corn plant with complex micronutrient fertilizers: Avatar-1, Nutrimix, which are included into the Register of allowed for the use in Ukraine pesticides. The application method - foliar fertilization at the stage of 3-5 and 7-8 leaves.

The agro-technology of corn hybrids cultivation in the experiments was generally accepted for the zone of Southern Steppe of Ukraine ${ }^{15}$. The forecrop was soybean. The sowing of corn was carried out in the first decade of May, when the soil temperature at the depth of seed wrapping was $12-14^{\circ} \mathrm{C}$.

The arable layer is within the range of $0-30 \mathrm{~cm}$. The field capacity of the soil layer is $22.0 \%$, the wilting point $-9.7 \%$ of the dry soil mass, the bulk density $-1.40 \mathrm{~g} / \mathrm{cm}^{3}$. The humus content in the arable layer of the soil is $2.2 \%$. The power of Hydrogen in the soil extraction of the upper horizons is close to neutral or weakly alkaline $(\mathrm{pH}=6.9-7.4)$, it increases by the profile. The soil is typical for the Steppe zone by its characteristics.

The main criterion for irrigation regime planning was the level of total available water (TAW). The vegetation period of corn was conditionally divided into three stages: the first - «germination - flowering», the second «flowering - milk ripeness», the third - «milk ripeness - full ripeness». The biologically optimal regime of corn irrigation was a mode in which at all stages of organogenesis TAW was maintained at the level of $80 \%$ FC.

15 Науково-практичні рекомендації з технології вирощування кукурудзи в умовах зрошення Південного Степу України. Херсон: Грінь Д.С., 2015. 104 с. 
The results of the yield evaluation were processed by the methods of ANOVA, correlation and statistical analysis with accordance to methodological recommendations ${ }^{16,17}$.

\section{Results and their discussion}

By the height of plants there was a clear ranking of the hybrids depending on the group of ripeness at the main stages of growth and development of the crop (Table. 1). The difference in this index between middle-early (FAO 200-290), middle (FAO 300-390), and middle-late (FAO 400-490) hybrids has already been observed at the stage of 12-13 leaves, but the most significant $(12-24 \mathrm{~cm})$ it was at the stage of cobs flowering and milk ripeness of grain. In general, the difference in the plant height between the hybrids for ripeness groups is fully anticipative and does not contradict the general biological position.

Corn plants treatment with micronutrients positively affected the height of plants of the hybrids in all the estimated stages of the growth and development of the crop. The greatest impact on the growth processes was caused by an Avatar-1 preparation, which ensured the increase in the plant height, in comparison to the untreated control, by 1-7 cm. The use of micronutrient fertilizers Nutrimix, in general by the variants of the experiment, had the minimum effect on the growth processes (increase by the growth and development stages of the crop was $1-3 \mathrm{~cm}$ ).

The analysis of the height formation of the corn plants depending on the FAO group and the effects of micronutrient fertilizers has a valuable utilitarian value in the combination with the grain yields and the determination of the optimum biometric parameters of corn hybrids by some FAO groups.

Among the studied hybrids, the largest plant height in all the stages of development was in the middle-late hybrid Chongar (FAO 420) with the maximum at the stage of milk ripeness under the treatment with Avatar-1 $267 \mathrm{~cm}$. It is determined that between the height of the plants, the height of the cob setting, the area of the assimilation surface and the grain yield of hybrids there is a close correlation at the level $r=+0.873 ;+0.745$, and +0.883 , respectively, which testifies about the possibility of preliminary visual assessment on these features of the productivity in the field conditions.

16 Вожегова Р. А., Лавриненко Ю. О., Малярчук М. П. Методика польових і лабораторних досліджень на зрошуваних землях. Херсон: Грінь Д.С., 2014. 286 с.

17 Ушкаренко В. О., Нікішенко В. Л., Голобородько С. П., Коковіхін С. В. Дисперсійний і кореляційний аналіз результатів польових дослідів Херсон: Айлант, 2009. $372 \mathrm{c}$. 
Table 1

The height of the plants and the height of the cob setting in the hybrids of corn depending on the ripeness group and treatment with micronutrients (average for 2016-2018)

\begin{tabular}{|c|c|c|c|c|c|}
\hline \multirow{2}{*}{$\begin{array}{l}\text { Hybrid - } \\
\text { factor A }\end{array}$} & \multirow{2}{*}{$\begin{array}{c}\text { Micronutrient } \\
\text { Fertilizers - factor } B\end{array}$} & \multicolumn{3}{|c|}{$\begin{array}{l}\text { Plant height }(\mathrm{cm}) \text { according to } \\
\text { the growth stages and the crop } \\
\text { development }\end{array}$} & \multirow{2}{*}{$\begin{array}{l}\text { The height } \\
\text { of the cob } \\
\text { setting, cm }\end{array}$} \\
\hline & & $\begin{array}{l}12-13 \\
\text { leaves }\end{array}$ & $\begin{array}{l}\text { Flowerin } \\
\mathrm{g} \text { of cobs }\end{array}$ & $\begin{array}{c}\text { Milk } \\
\text { ripeness }\end{array}$ & \\
\hline \multirow{3}{*}{$\begin{array}{l}\text { DN Galateya } \\
\text { (FAO 250) }\end{array}$} & $\begin{array}{c}\text { Without treatment - } \\
\text { control }\end{array}$ & 148 & 239 & 242 & 104 \\
\hline & Avatar-1 & 154 & 243 & 246 & 105 \\
\hline & Nurtrimix & 152 & 241 & 245 & 105 \\
\hline \multirow{3}{*}{$\begin{array}{l}\text { Skadovskyi } \\
\text { (FAO 290) }\end{array}$} & $\begin{array}{l}\text { Without treatment - } \\
\text { control }\end{array}$ & 144 & 232 & 237 & 101 \\
\hline & Avatar-1 & 146 & 233 & 239 & 102 \\
\hline & Nurtrimix & 145 & 232 & 238 & 102 \\
\hline \multirow{3}{*}{$\begin{array}{l}\text { DN Demetra } \\
\text { (FAO 300) }\end{array}$} & $\begin{array}{l}\text { Without treatment - } \\
\text { control }\end{array}$ & 150 & 244 & 252 & 94 \\
\hline & Avatar-1 & 158 & 248 & 254 & 98 \\
\hline & Nurtrimix & 155 & 246 & 254 & 96 \\
\hline \multirow{3}{*}{$\begin{array}{l}\text { Ingulskyi } \\
\text { (FAO 350) }\end{array}$} & $\begin{array}{l}\text { Without treatment - } \\
\text { control }\end{array}$ & 153 & 243 & 250 & 105 \\
\hline & Avatar-1 & 160 & 248 & 254 & 107 \\
\hline & Nurtrimix & 155 & 246 & 253 & 106 \\
\hline \multirow{3}{*}{$\begin{array}{l}\text { DN Bereka } \\
\text { (FAO 390) }\end{array}$} & $\begin{array}{l}\text { Without treatment - } \\
\text { control }\end{array}$ & 151 & 246 & 254 & 116 \\
\hline & Avatar-1 & 161 & 256 & 261 & 118 \\
\hline & Nurtrimix & 153 & 248 & 255 & 117 \\
\hline \multirow{3}{*}{$\begin{array}{l}\text { Chongar } \\
\text { (FAO 420) }\end{array}$} & $\begin{array}{c}\text { Without treatment - } \\
\text { control }\end{array}$ & 158 & 254 & 261 & 126 \\
\hline & Avatar-1 & 162 & 256 & 267 & 128 \\
\hline & Nurtrimix & 161 & 255 & 264 & 127 \\
\hline \multirow{3}{*}{\multicolumn{2}{|c|}{$\begin{array}{l}\mathrm{LSD}_{05} \text { Factor } \mathrm{A} \\
\text { Factor } \mathrm{B} \\
\text { Interaction of } \mathrm{AB}\end{array}$}} & 2.94 & 3.12 & 2.29 & 2.18 \\
\hline & & 3.15 & 4.12 & 3.13 & 3.12 \\
\hline & & 3.18 & 4.25 & 3.11 & 3.19 \\
\hline
\end{tabular}

The results of the ANOVA found out that the greatest influence on the plant height had a hybrid composition - the share of influence was $65.2 \%$.

This confirms the preliminary conclusion that the main factor of grain yields is a group of hybrid ripeness, and the plant height indirectly affects the grain yield of the hybrids due to the potential productivity of the genotypes with a longer FAO.

The treatment with regulating preparations had less effect on the plant height $-31.8 \%$. The interaction of the studied factors is insignificant $-2.5 \%$ and the index of the residual action were not significant. 
One of the parameters of technological appropriateness of corn hybrids is the height of the productive (upper) cob setting, because its low location leads to significant losses during harvesting. The height of the cob setting was changed in a rather wide range - from 94 to $129 \mathrm{~cm}$ (Table 1). The highest location was in the middle-late hybrid and the lowest - in the middle-ripening hybrid DN Demetra. Micro-fertilizers increased the height of the cob setting - by $1-3 \mathrm{~cm}$.

For the optimum photosynthesis process, corn crops should have a certain area of leaf surface, which serves as a means of the accumulation of plastic substances for the formation of grain yield of the hybrids. In the conditions of irrigation, the intensity of physiological processes of corn intensifies - the area and productivity of leaves and water content and dry matter in the leaves increases.

The conducted researches found out that the increase of the leaf area surface per plant of corn increased significantly with the growth and development of the plants. At the beginning of vegetation of plants, the area of leaf surface was almost the same at all the investigated variants, however, at the stage of $12-13$ it leaves was noted a significant increase of this parameter, on average, by 6.7-8 times, compared to the similar parameters at the stage of 7 leaves. The largest indexes of the leaf area, on the control variant, on average, by the Factor A (hybrids) $-0.421 \mathrm{~m}^{2}$ had the plants of middle-late corn hybrids. The ripeness group of hybrids caused fluctuations in the leaf surface area, which at the stage of 12-13 leaves was the highest on the plots with the middle-late hybrid Chongar and was, on average by the Factor A (hybrid), $0.424 \mathrm{~m}^{2}$. On the other hybrids the index decreased on average by $3.3-10.2 \%$ compared with the hybrid Chongar. The maximum value of the leaf surface area on all the variants has been observed at the cobs flowering stage. The highest this index was at the middle-late hybrid Chongar under the use of Avatar-1 and averaged to $0.668 \mathrm{~m}^{2}$ per plant. The least leaf surface area was formed on the hybrids of early-ripening group Skadovskyi $\left(0.481 \mathrm{~m}^{2}\right.$ per plant $)$ and DN Galateya $\left(0.451 \mathrm{~m}^{2}\right)$ on the variants without the use of preparations. In this period, all the hybrids of corn had the highest indexes of the leaf surface area. In the next stages of the plants of the crop slightly decreased. So, at the stage of milk grain ripeness the area of the leaf surface, on average by the hybrids, averaged to $0.441 \mathrm{~m}^{2}$ in the middleearly group, $0.537 \mathrm{~m}^{2}$ in the middle-ripening group, $0.627 \mathrm{~m}^{2}$ per plant in the middle-late group of the hybrids.

Treatment of corn with micronutrients positively affected the dynamics of the leaf surface area of the hybrids by the individual stages of development. The greatest impact on the leaf surface area was caused by the 
preparation Avatar-1, which provided the additional growth by the individual developmental stages, compared to the control, by $0.029-0.048$ $\mathrm{m}^{2}$. Micronutrient fertilizer Nutrimix, on average by the experiment, had the minimal influence on the area of leaf surface (increase of $0.018-0.029 \mathrm{~m}^{2}$ per plant by the stages of development).

The accumulation of organic matter and yield correlates with the area and the activity of the leaf apparatus, its capacity to accumulate solar energy. This is confirmed by the calculations of the polynomial dependence of the area of the leaf surface of the plants of hybrids and grain yield (Fig. 1).

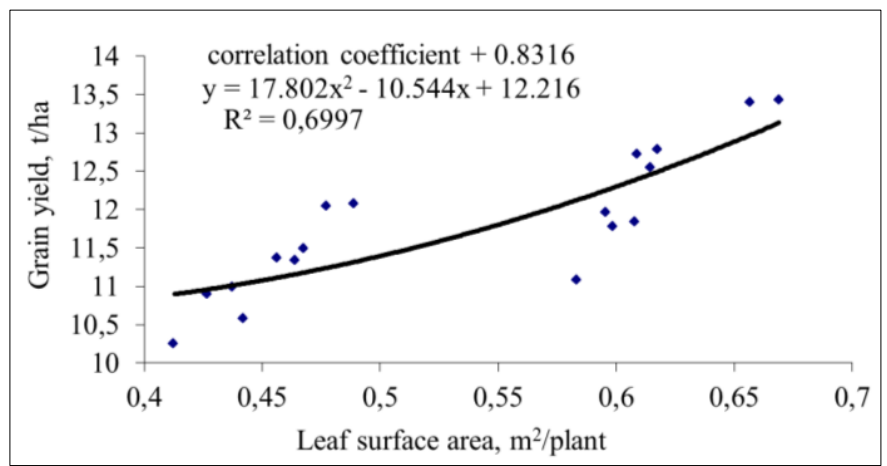

Fig. 1. Polynomial trend line of the dependence of the area of leaf surface of the plants of corn hybrids and grain yields (2016-2018)

Treatment of corn with micronutrients positively affected the dynamics of the area of leaf surface of the hybrids by individual developmental stages. The greatest influence on the leaf surface area was caused by the preparation Avatar-1, which provided the additional growth by the individual stages of development, compared to the control, by $7-11 \%$. Micronutrient fertilizer Nutrimix, on average by the study, had the minimal influence on the area of leaf surface (the increase by $4-9 \%$ ) by the individual stages of development.

Accumulation of raw and dry herbage mass of corn plants are important characteristics of corn plants, which play significant role in the process of the productivity formation of modern corn hybrids. These indexes are physiologically connected with the group of ripeness of hybrids, which indirectly affects the grain yield. At the treatment of corn crops with the preparation Avatar-1, we received the largest increase in raw herbage mass in all the studied hybrids. At this variant of treatment, the highest green mass rates in the hybrids of middle-early group averaged to $3.40-50.73 \mathrm{t} / \mathrm{ha}$, the 
middle-ripening group - 3.65-53.03, the middle-late hybrid Chongar 3.88-54.71 t/ha, depending on the stage of development.

At the stage of physiological maturity, there is a decrease of green mass yield on all the variants, which is explained by the redistribution of plastic substances from vegetative bodies to reproductive, mainly, for the formation of grain. The greatest value of the green mass outlet is $37.19 \mathrm{t} / \mathrm{ha}$ fixed in the hybrid Chongar (Fig. 2).

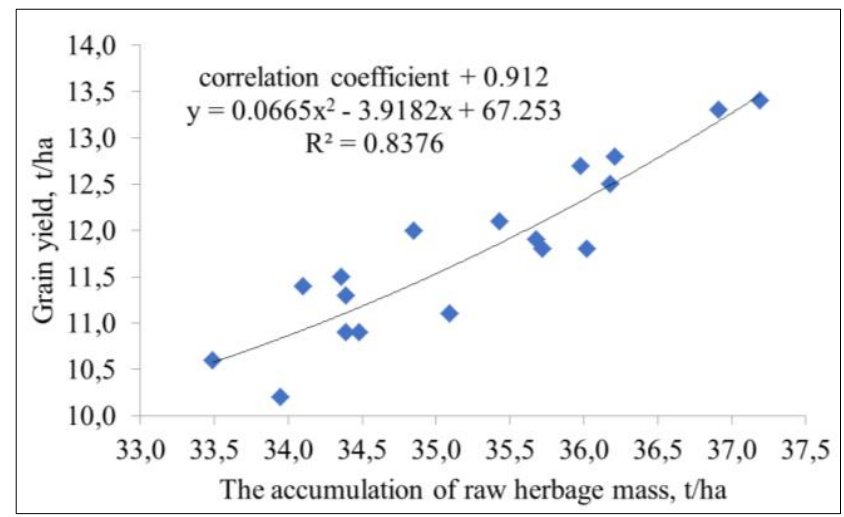

Fig. 2. Polynomial trend line of the dependence of raw herbage mass of corn hybrids at the stage of physiological ripeness and grain yield (2016-2018)

It was established that there is a high positive correlation between the accumulation of dry herbage mass and grain yield of the hybrids. Thus, at the stage of physiological ripeness, correlation coefficient between the accumulation of dry herbage mass and grain yields of the hybrids was + 0.863 .

The data concerning the accumulation of herbage mass of the corn plants testify that the hybrids with a longer period of vegetation and more productive ones form considerably more both raw and dry matter.

Determination of the influence on the indexes of the accumulation of dry mass of the hybrid composition showed that the least level of dry mass accumulation was at the cultivation of middle-early hybrids Skadovskyi and DN Galateya where dry herbage mass at the stage of physiological ripeness fluctuated within 19.25-20.81 t/ha. Application of the preparation Avatar-1 provided the gain of dry mass by $6.9-7.1 \%$ in these hybrids. The use of the preparation Nutrimix provided the gain of dry mass by $6.0-6.2 \%$. The 
maximum values of dry mass are fixed in the hybrids DN Bereka and Chongar -21.63 and $21.83 \mathrm{t} / \mathrm{ha}$. However, they had the minimum increase of the dry mass due to the action of micro-fertilizers that constituted 0.6-1.2\% (Nutrimix) and 2.0-2.1\% (Avatar-1). The growth of the group of ripeness by FAO from 290 to 420 provided the increase in the accumulation of dry mass by $10.0-11.2 \%$ (Fig. 3).

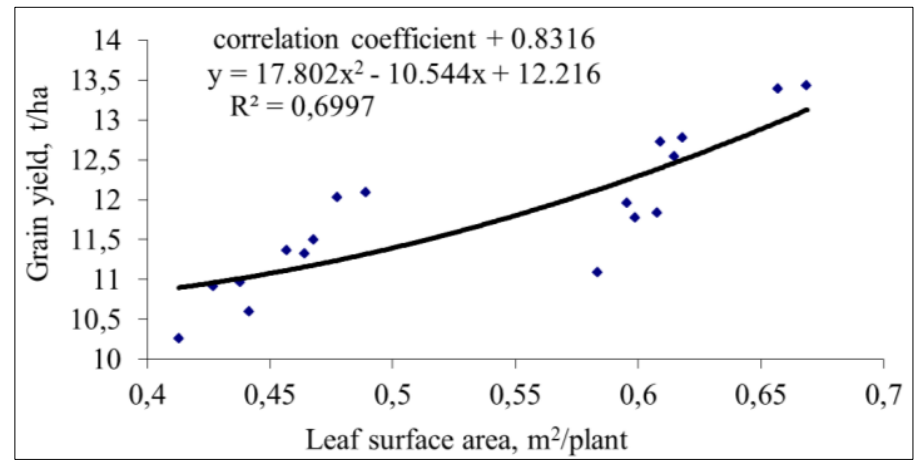

Fig. 3. Polynomial trend line of the dependence of dry herbage mass of corn hybrids and yield at the stage of physiological maturity (2016-2018)

The formation of high yield of high-quality corn grain is caused by the main structural elements, which include the weight of 1000 seeds, the number of grain rows, the number of grains in a row, the number of grains per cob, the length and diameter of the cob.

The studied hybrids revealed the peculiarities of formation of the elements of crop structure, depending on a group of ripeness and treatment with micronutrients. The size of the ears, which were formed on the corn plants, was typical for a particular type of hybrid (Table. 2).

At the determination of the length of the cobs, we took under consideration only its part with grain. By the results of biometric measurements, the least average length of the cob was determined in the middle-early hybrid DN Galateya - 16.8-17.3 cm. With the increase of the FAO group, an index of the length of the cob was increased, due to the hybrids characteristic. Thus, the value of this index for the hybrid Skadovskyi, on average for the period of observations during 2016-2018, was $17.8-18.5 \mathrm{~cm}$; for the middle-ripening hybrids DN Demetra - 18.4-19.0 cm and Ingulskyi - 17.2-17.9 cm, DN Bereka-19.4-20.1 cm. The highest value of the index was determined in the middle-late hybrid Chongar $-20.3-22.6 \mathrm{~cm}$. 
Table 2

Indexes of the yield structure of corn hybrids of different groups of ripeness depending on the treatment with micronutrients (average for 2016 - 2018)

\begin{tabular}{|c|c|c|c|c|c|c|}
\hline $\begin{array}{c}\text { Factor A, } \\
\text { Hybrid }\end{array}$ & $\begin{array}{l}\text { Factor in, } \\
\text { Treatment of } \\
\text { micronutrient } \\
\text { Fertilizerm }\end{array}$ & $\begin{array}{l}\text { The } \\
\text { length of } \\
\text { the cob, } \\
\text { CM }\end{array}$ & $\begin{array}{l}\text { Diamete } \\
\text { r of the } \\
\text { cob, } \\
\text { mm }\end{array}$ & $\begin{array}{c}\text { Number } \\
\text { of grain } \\
\text { rows }\end{array}$ & $\begin{array}{c}\text { Grain } \\
\text { weight } \\
\text { from cob, } \\
\mathrm{g}\end{array}$ & Yield, t/ha \\
\hline \multirow{3}{*}{$\begin{array}{c}\text { DN Galateya } \\
\text { (FAO 250) }\end{array}$} & Without & 16.8 & 39.9 & 15.2 & 154.6 & 10.3 \\
\hline & Avatar-1 & 17.3 & 41.4 & 15.8 & 158.3 & 10.9 \\
\hline & Nurtrimix & 17.1 & 40.7 & 15.4 & 156.9 & 10.9 \\
\hline \multirow{3}{*}{$\begin{array}{l}\text { Skadovskyi } \\
(\text { FAO 290) }\end{array}$} & Without & 17.9 & 43.8 & 14.6 & 169.4 & 10.6 \\
\hline & Avatar-1 & 18.5 & 44.6 & 15.3 & 173.2 & 11.5 \\
\hline & Nurtrimix & 18.3 & 44.1 & 15.1 & 172.0 & 11.4 \\
\hline \multirow{3}{*}{$\begin{array}{c}\text { DN Demetra } \\
\text { (FAO 300) }\end{array}$} & Without & 18.4 & 47.8 & 18.0 & 173.5 & 11.3 \\
\hline & Avatar-1 & 19.0 & 48.2 & 18.4 & 185.3 & 12.1 \\
\hline & Nurtrimix & 18.7 & 47.9 & 18.1 & 181.8 & 12.0 \\
\hline \multirow{3}{*}{$\begin{array}{l}\text { Ingulskyi } \\
\text { (FAO 350) }\end{array}$} & Without & 17.2 & 35.6 & 14.3 & 167.8 & 11.1 \\
\hline & Avatar-1 & 17.9 & 37.2 & 14.7 & 180.1 & 11.8 \\
\hline & Nurtrimix & 17.6 & 38.5 & 14.4 & 179.3 & 11.8 \\
\hline \multirow{3}{*}{$\begin{array}{l}\text { DN Bereka } \\
(\text { FAO 390) }\end{array}$} & Without & 19.4 & 41.9 & 14.9 & 276.4 & 11.9 \\
\hline & Avatar-1 & 20.1 & 44.3 & 15.8 & 282.6 & 12.8 \\
\hline & Nurtrimix & 19.7 & 43.0 & 15.2 & 280.9 & 12.7 \\
\hline \multirow{3}{*}{$\begin{array}{l}\text { Chongar } \\
(\text { FAO 420) }\end{array}$} & Without & 20.3 & 50.6 & 18.5 & 278.0 & 12.5 \\
\hline & Avatar-1 & 22.6 & 52.4 & 19.1 & 289.7 & 13.4 \\
\hline & Nurtrimix & 21.1 & 51.8 & 18.6 & 285.8 & 13.3 \\
\hline \multirow{3}{*}{$\mathrm{LSD}_{05}$} & Factor A & 0.42 & 0.85 & 0.12 & 5.21 & 0.4 \\
\hline & Factor B & 0.35 & 0.96 & 0.18 & 6.14 & 0.6 \\
\hline & Interaction of & 0.29 & 0.79 & 0.10 & 4.99 & 0.5 \\
\hline
\end{tabular}

Providing of the corn plants with microelements for growth and development has caused the increase of biometric indexes of the cobs. Larger values of the cob length were under the use of micro-fertilizers Nutrimix and Avatar-1, when the increase was, in comparison to the control, 2.5 and $4.9 \%$, respectively.

The index of the diameter of the cob has not almost changed under the influence of the studied factors, but it depended on the genotypical features of the hybrids and averaged, for the 2016-2018 period, for the hybrid DN Galateya - 39.9-41.4 mm, for the hybrid Skadovskyi - 43.8-44.6 mm, for hybrid DN Demetra - 47.8-48.2 mm, Ingulskyi - 35.6-38.5 cm, and DN Bereka - 41.9-44.3 mm. The greatest value of the index - the diameter of the cob - was observed in the middle-late hybrid Chongar - 50.6-52.4 mm.

By the results of the measurements, it was established that the use of micronutrient fertilizers Nutrimix, Avatar-1 contributed to the stable increase in the length and diameter of the cobs of the corn hybrids of different FAO groups. Thus, in the areas where micro-fertilizers were applied, in comparison to the untreated control, the increase reached the 
value for the cob length of 2.5-4.9\% $(0.45-0.9 \mathrm{~cm})$ and for the diameter of $2.3-3.2 \%(1.0-1.4 \mathrm{~mm})$.

The number of the grain rows increased mainly with the increase of the FAO group. Thus, on the control variants without treatment the number of grain rows, on average for the years of the study, reached 15.9, in the group of middle-early hybrids averaged to 14.9 in the group of middle-ripening 15.7, in the middle-late ripening hybrid Chongar the number of grain rows was 18.5 .

The same regularity was in the mass of grain per cob. On the variant without treatment with micro-fertilizers, the maximum values of the mass of grain per cob was observed in the middle-late hybrid Chongar on the control variant $-278.0 \mathrm{~g}$. By the middle-early ripening group of FAO, the mass of grain per cob was $162.0 \mathrm{~g}$, by the middle-ripening - $205.9 \mathrm{~g}$. The use of micro-fertilizers had a little less impact, compared to the group of FAO, but on average by the factor, the treatment with micronutrient fertilizers Nutrimix and Avatar-1 increased the productivity by $2.0-8.3 \mathrm{~g}$, or by $0.7-3.8 \%$. The maximum values of grain weight per cob was on the variants with the application of micro-fertilizer Avatar-1 and constituted, on average by all the FAO groups $-211.5 \mathrm{~g}$ that is more by $3.8 \%$ than the control and by $1 \%$ in comparison to the treatment with Nutrimix.

Modeling between the yields of corn and grain weight per cob allowed determining significant difference between the studied hybrids and micronutrient fertilizers treatment. The correlation coefficient in this case is +0.864 .

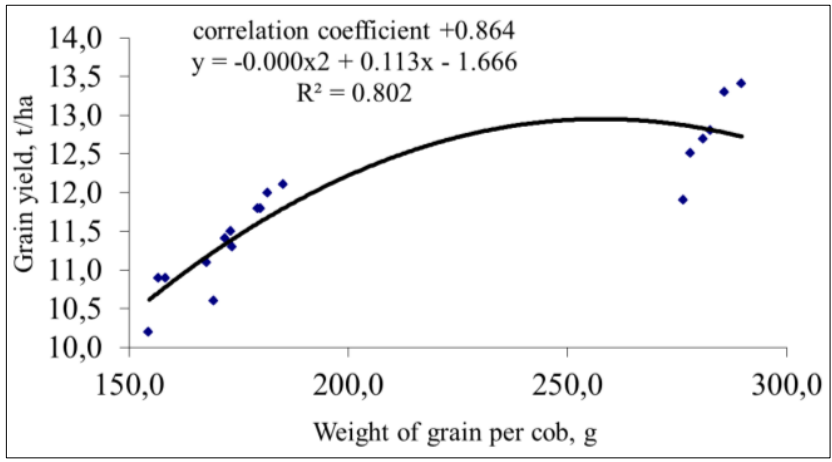

Fig. 4. Polynomial trend line of the grain weight per cob of the corn hybrids and grain yields, 2016-2018 
The study of the correlation dependence between the yields and other major economically valuable features is of practical importance for the determination of optimal parameters in the process of development of corn hybrids agricultural technology for the cultivation of them in the specific agro-climatic zones.

By the analysis of correlation dependencies between the indexes of the structure and the yield of corn grain, a high tie was established. Thus, the correlation coefficient between the grain yield and the length of the cob was $\mathrm{r}=+0.915$, the diameter of the cob $\mathrm{r}=+0.624$, the number of grain rows $r=+0.581$ and the weight of grain per cob $r=+0.864$.

According to the conducted simulation it was proved that the length of the cob of the corn hybrids is significantly affected by the yield of grain. The maximum yield of corn grain is formed in the hybrids with the length of the cob more than $22 \mathrm{~cm}$ (Fig. 4).

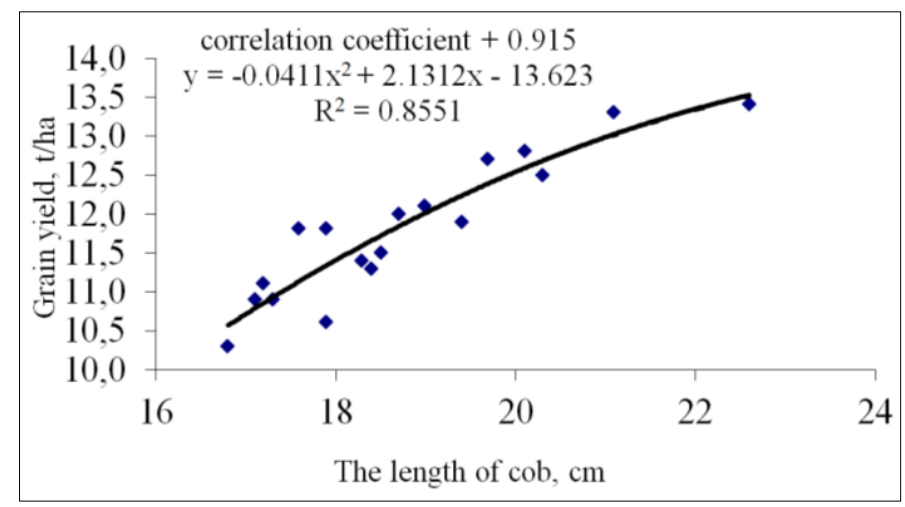

Fig. 5. Polynomial trend line of the length of the cob of the corn hybrids and the yield of grain, 2016-2018

The diameter of the cob had less effect on the grain yield of the hybrids. The maximum yield was formed at the diameter of the cob of 50-55 mm. 


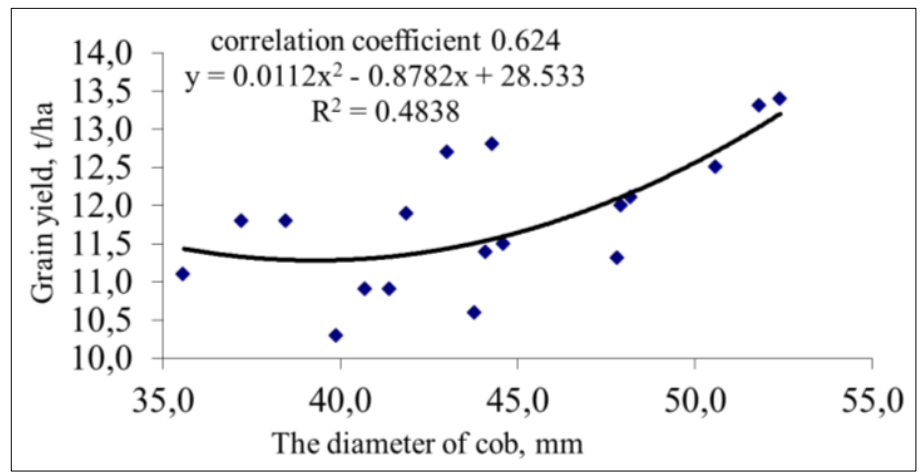

Fig. 6. Polynomial trend line of the diameter of the cob of the corn hybrids and the yield of grain, 2016-2018

The correlation between the yields of corn grain and grain mass per cob allowed determining significant difference between the studied hybrids. The correlation coefficient was +0.864 .

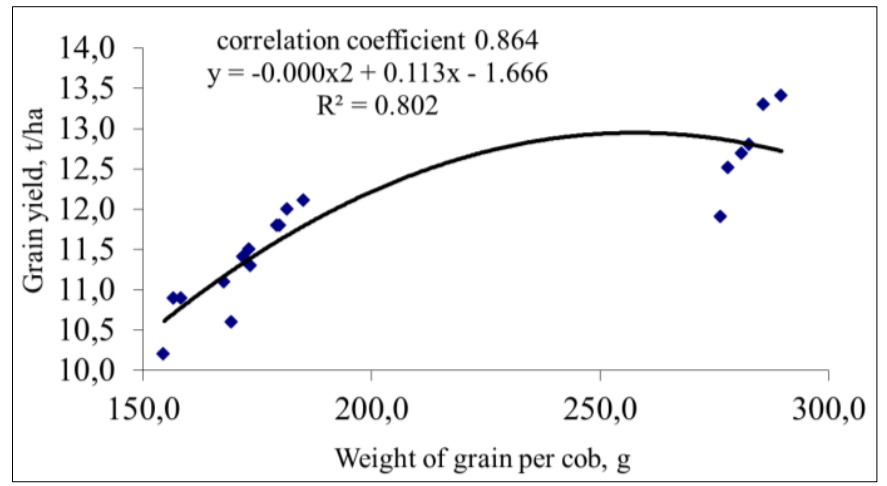

Fig. 7. Polynomial trend line of the grain weight per cob of the corn hybrids and the grain yields, 2016-2018

Weight of 1000 seeds is one of the most important indexes of the corn structure, which effects the formation of high productivity.

In our researches, this index fluctuated under the influence of the studied factors, but their influence was not equal (Table. 3). 
Table 3

Weight of 1000 seeds of the corn hybrids of different groups by FAO depending on the treatment with micronutrient fertilizers, $g$ (average for 2016-2018)

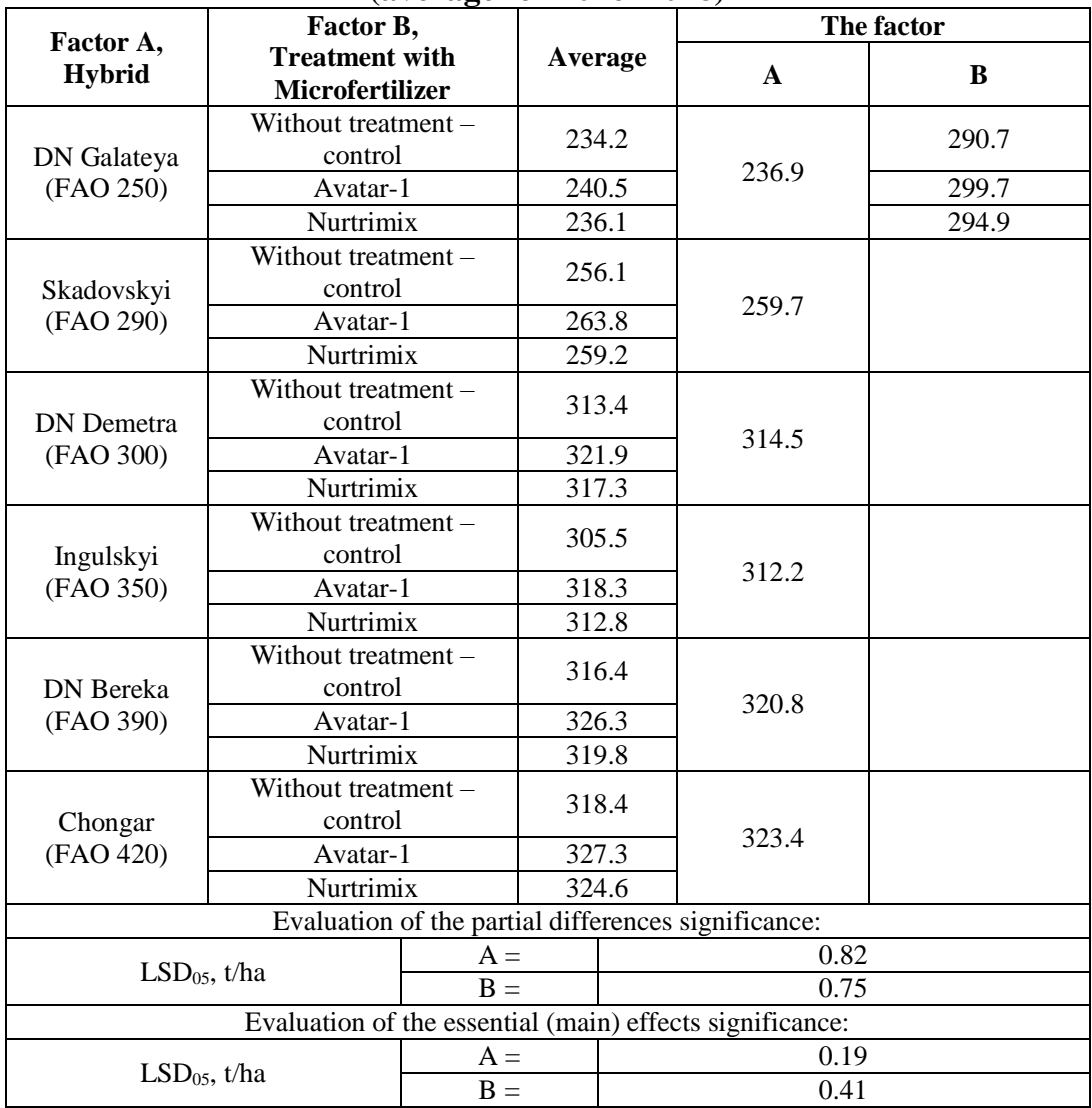

Weight of 1000 corn seeds in the studies fluctuated depending on the studied factors. The use of micro-fertilizers treatment helped to increase the weight of 1000 seeds, but the most influence on the weight of 1000 seeds had the group of ripeness of hybrid. The value of this index in the middleearly group averaged at the treatment with micro-fertilizer Avatar-1 and Nutrimix to 252.2 and $247.7 \mathrm{~g}$, respectively. At the application of microfertilizers, on average, this index was higher by $4.2-9.0 \mathrm{~g}$, compared to the untreated control. 
The performed analysis showed that the weight of 1000 corn seeds in different groups of FAO fluctuated within 234.2-327.3 g. The least weight of 1000 seeds - $234.2 \mathrm{~g}$ was formed at the sowing of the hybrid DN Galateya without the treatment with micronutrient fertilizers. The highest average weight of 1000 seeds (in the control variant) was defined in the hybrid Chongar $-318.4 \mathrm{~g}$.

Among the middle-ripening group of hybrids, the biggest weight of 1000 seeds had the hybrid DN Bereka - 316.4 g. At the treatment with the preparation Avatar-1, the weight of 1000 seeds increased by $3.1 \%$.

The maximum weight of 1000 seeds, on average for the years of the study (327.3 g), was received at the sowing of the hybrid Chongar at the treatment with micro-fertilizer Avatar-1.

The analysis of the obtained experimental data showed that there is a close tie between the indexes of yield and weight of 1000 seeds of the corn hybrids of different groups of ripeness. The correlation coefficient was 0.805 .

\section{CONCLUSIONS}

It was determined that between the height of plants, the height of the cob setting, the area of the assimilation surface and the grain yield of the hybrids there is a tight correlation at the level $r=0.873 ; 0.745$ and 0.883 , respectively, which may indicate the possibility of previous visual evaluation of these parameters on the productivity in the field.

The ratio of the plant height of the hybrids by the ripeness groups and the yield level showed that for the middle-early group (FAO 200-290) at the stage of the linear growth cessation the optimal plant height is $240-250 \mathrm{~cm}$, the grain yield in this case is $11.2-11.5 \mathrm{t} / \mathrm{ha}$; for the middle-ripening group (FAO 300-390) - $255 \mathrm{~cm}$ with the grain yield at the level of $11.8-12.1 \mathrm{t} / \mathrm{ha}$; for the middle-late hybrids (FAO 400-490) the optimum plant height to ensure the highest grain yield (more than $13 \mathrm{t} / \mathrm{ha}$ ) is in the range from 265 to $270 \mathrm{~cm}$. The optimum height of the plants and the maximum yields can be achieved in the irrigated conditions at the use of the corn hybrids of the relevant group of ripening and the use of complex micro-fertilizers.

Treatment of the corn plants with fertilizers had a positive effect on the dynamics of the assimilation surface area of the hybrids by the stages of growth and development of the plants. The greatest influence on the assimilation surface area was caused by the preparation Avatar-1, which provided the increase at certain stages of the development, compared to the untreated control, at the level of $0.029-0.048 \mathrm{~m}^{2} /$ plant. 
Treatment of the corn with micronutrients had a positive effect on the accumulation of the raw herbage mass of the hybrids, by the certain stages of development. Among the studied hybrids, the maximum indexes of the raw herbage accumulation were observed in the middle-late hybrid Chongar (FAO 420) in the case of a use of the complex micro-fertilizer Avatar-1, and by the stages of development it increased up to $54.71 \mathrm{t} / \mathrm{ha}$ in the milk ripeness stage. It was determined that between the accumulation of raw herbage mass, dry herbage mass and the grain yield of the hybrids there is a tight correlation at the level of $+0.912,+0.863$, which may indicate the possibility of a preliminary evaluation of these parameters of productivity in the field conditions.

The study showed that treatment with micronutrients affects the formation of the elements of the structure of corn grain yield. The highest indexes of all the structural elements were observed at the sowing of the hybrids of middle and middle-late FAO group under the treatment with micro-fertilizer Avatar-1. The maximum values of the indexes of the cob structure and yield were observed in the hybrid Chongar, treated with the micro-fertilizer Avatar-1.

The optimum of the cob structure indexes of the plants and the maximum yield could be achieved in the irrigated conditions at the use of the corn hybrids of the relevant groups of ripeness and complex micro-fertilizers.

\section{SUMMARY}

The article presents the results of the researches on the definition of innovative elements of cultivation technology for corn hybrids of different FAO groups in the conditions of irrigation. The manifestation of biometric characteristics of the corn hybrids of different FAO groups is studied, and their connection with the grain yield was found out when cultivating them at drip irrigation in Southern Steppe of Ukraine. The effect of micro-fertilizers on the dynamics of biometric parameters of the corn hybrids plants was determined.

The manifestation of the indexes of the plant structure of modern corn hybrids of different FAO groups was defined and their connection with the yield of grain was elucidated. The influence of micro-fertilizers on the indexes of the corn hybrids yield and reasonable agro-technical recommendations for obtaining high grain yields of the crop were determined.

The correlation dependence between the yields and other major economically valuable features, which have practical significance for the determination of the optimal parameters in the process of the cultivation 
technology development for the corn hybrids for specific agro-climatic zones, was studied.

The optimum of the structure of the cob of the crop and the maximum yield could be achieved in the irrigated conditions through the use of the corn hybrids of relevant ripeness groups and complex micro-fertilizers.

\section{REFERENCES}

1. Лавриненко Ю. О., Нужна М. В., Боденко Н. А. Моделі гібридів кукурудзи FАO 150-490 для умов зрошення. Plant Varieties Studying and

Protection. 2018. T. 14, № 1. C. 58-64. doi:10.21498/25181017.14.1.2018.126508.

2. Токмакова Л. М., Трепан А. О., Шевченко Л. А. Ефективність фосфорного живлення рослин кукурудзи за дії поліміксобактерину. Вісник Полтавської державної агарної академії. 2019. № 1. С. 73-80. doi:10.31210/visnyk2019.01.09

3. Lavrynenko Yu. O., Hozh O. A., Vozhegova R. A. Productivity of corn hybrids of different FAO groups depending on microfertilizers and growth stimulants under irrigation in the south of Ukraine. Agricultural science and practice. 2016. № 1. P. 55-60.

4. Mason S., Kmail Z., Galusha T., Jukić Ž. Path analysis of drought tolerant maize hybrid yield and yield components across planting dates. Journal of Central European Agriculture. 2019. 20(1). P. 194-207. https://doi.org//10.5513/JCEA01/20.1.2106

5. Milander J., Jukić Ž., Mason S. Hybrid maturity influence on maize yield and yield component response to plant population in Croatia and Nebraska. Cereal Research Communications. 2017. Vol. 45, Iss. 2. P. 326-335. https://doi.org/10.1556/0806.45.2017.015

6. Irmak S., Djaman K. Effects of planting date and density on plant growth, yield, evapotranspiration, and water productivity of subsurface dripirrigated and rainfed maize. Transactions of the ASABE. 2016. 59(5). P. 1235-1256. doi: 10.13031/trans.59.11169

7. Котченко М. В., Кірсанова Г. В., Пугач А. М., Пугач А. В. Продуктивність різностиглих гібридів кукурудзи в умовах Північного Степу України. Вісник Полтавської державної аграрної академії. 2016. № 4. C. 27-30. doi.org/10.31210/visnyk2016.04.04

8. Calvino P. A., Andradeb F. A., Sadrasb V. O. Maize Yield as Affected by Water Availability, Soil Depth, and Crop Managemen. Agronomy Journal. 2003. № 95. 275-281.

9. Troyer A. F., Background U. S. Hybrid Corn II. Crop Science. 2004. Vol. 44. No. 2, P. 370-380. doi:10.2135/cropsci2004.3700

10. Лавриненко Ю. О., Михайленко І. В., Хоменко Т. М. Біометричні показники гібридів кукурудзи різних груп ФАО залежно від 
обробки мікродобривами за умов зрошення. Plant Varieties Studying and protection. 2019. Vol. 15, № 1. C. 71-79. doi.org/10.21498/2518$1017 / 15 / 1 / 2019 / 162486$

11. Лавриненко Ю. О., Вожегова Р. А., Гож О. А. Продуктивність гібридів кукурудзи різних груп ФАО залежно від стимуляторів росту та мікродобрив в умовах зрошення на півдні України. Вісник аграрної науки. 2016. № 7. C. 28-33.

12. Гож А. А., Лавриненко Ю. А., Глушко Т. В., Лашина М. В. Агротехнологические аспекты формирования продуктивности гибридов кукурузы на орошаемых землях юга Украины. Современные энерго- и ресурсосберегающие, экологически устойчивые технологии и системы сельскохозяйственного производства. Рязань, 2014. № 11. С. 33-37.

13. Сухому О. Г., Адаменко Д. М., Кравець I. С., Суханов С. В. Вплив застосування мікродобрив ТМ «Актив-харвест» на ріст, розвиток i врожайність рослин кукурудзи. Вісник Уманського національного університету садівництва. 2019. № 94(1). С.156-164. doi.org/10.31395/24158240-2019-94-1-156-164

14. Глушко Т. В., Войташенко Д. П. Урожайність та якість зерна кукурудзи під впливом біопрепаратів в умовах зрошення Південного Степу України. Зрошуване землеробство. 2013. № 59. С. 44-47.

15. Науково-практичні рекомендації 3 технології вирощування кукурудзи в умовах зрошення Південного Степу України. Херсон: Грінь Д.С., 2015. 104 c.

16. Вожегова Р. А., Лавриненко Ю. О., Малярчук М. П. Методика польових і лабораторних досліджень на зрошуваних землях. Херсон: Грінь Д.С., 2014. 286 с.

17. Ушкаренко В. О., Нікішенко В. Л., Голобородько С. П., Коковіхін С. В. Дисперсійний і кореляційний аналіз результатів польових дослідів Херсон: Айлант, 2009. 372 с.

\section{Information about the author:} Marchenko T. Yu., Candidate (Ph.D.) of Agricultural Sciences, Senior Researcher, Head of the Plant Breeding Department,

Institute of Irrigated Agriculture of the National Academy of Agrarian Sciences of Ukraine Kherson, Naddniprianske, 73483, Ukraine 


\section{OPTIMIZATION OF CULTIVATION TECHNOLOGY OF SUNFLOWER HYBRIDS IN THE CONDITIONS OF THE SOUTH OF UKRAINE}

\section{Nesterchuk V. V.}

\section{INTRODUCTION}

In Ukraine, more than $90 \%$ of vegetable fats are produced from sunflower seeds. This crop is attractive to agricultural producers of the Steppe zone due to low production expenditures for the cultivation, the stability of demand for seeds and its high price in the market. A comparison of the global economic indexes of the world agriculture shows that the main oil crop in the vast majority of countries of the world is soybean. However, in Ukraine from a historical point of view and as a result of the specific regional peculiarities, particularly, favor of the soil-climatic conditions for cultivation of sunflower, the main oil crop was and is sunflower ${ }^{123}$.

The importance of this crop in food supply of the state, as well as an important export component, cannot be overestimated. Sunflower cultivation allows obtaining of two most important products, which have exceptional significance for the development of the food base of Ukraine - it is, firstly, a valuable vegetable oil, which is not inferior to animal fats by its nutritional value, and, secondly, cake (meal) that is a very valuable ingredient for balancing forage by the protein and amino acids, which is widely used in livestock, poultry farming, fish farming, etc. ${ }^{4}$. At present and on prospect, an actual problem is to increase the economic and energy efficiency of sunflower and to ensure the growing needs in high-quality seeds at the expense of selection of hybrid assortment, optimization of plants density and application of scientifically substantiated fertilization system, including the

\footnotetext{
1 Адаменко Т. Перспективи виробництва соняшнику в Україні в умовах зміни клімату. Агроном. 2005. №1. С. 12-14.

2 Ушкаренко В. О., Лазер П. Н., Шепель А. В. Економічна та біоенергетична ефективність вирощування соняшника різних груп стиглості в основних посівах при зрошенні. Таврійський науковий вісник. 1998. Вип. 8. С.10-15.

${ }^{3}$ Методика проведения полевых агротехнических опытов с масличными культурами / под общей редакцией В. М. Лукомца. Краснодар, 2007. С. 122-129.

4 Миронова Н. М. Напрямки зниження та шляхи вдосконалення структури виробничих витрат. Таврійський науковий вісник. 2006. Вип. 44. С. 326-333.
} 
application of foliar fertigation with complex fertilizers containing microelements 5 .

By commercial value, sunflower is not inferior to such important and widespread crops as wheat, corn, soybean, etc., and it is one of the most popular oilseed crops of Ukraine and other countries. The simplified cultivation technology and the high level of profitableness and profitability, increasing demand for seeds and sunflower oil in the domestic and world markets raises the need to increase acreage and increase the productivity of the crop ${ }^{6}$.

However, according to the researches and experience of producers at the production level, the genetic potential of sunflower is not opened by $50-70 \%$. It is proved that the efficiency of agricultural production belongs to complicated interrelated economic categories, which are based on the functioning of the systems of objective economic laws. It reflects one of the most important aspects of social production - effectiveness, which is reflecting the form and purpose of the process of agricultural production. Moreover, providing the characteristic of the final result, it is necessary to distinguish between the terms of the effect and the economic efficiency of the investigated elements of cultivation technologies of crops, including sunflower.

Economic and energy efficiency of production and processing of sunflower depends on the intricate complex of natural-economic, technological, scientific-technical and other factors. To optimize the cultivation technology, increase economic and energy efficiency, the following main peculiarities should be taken into account: high level of requirements to cultivation conditions; hypersensitivity to herbicides; possibility of epiphytotia of the agents of diseases, which can lead to significant loss of yield and deterioration of seed quality ${ }^{78}$.

\section{Dynamics of the product process indexes of sunflower plants depending on the hybrid assortment, plant density and microfertilizers}

The field experiments with sunflower hybrids were carried out during 2014-2016 at the research farm «Kopani» of the Institute of Irrigated Agriculture of NAAS of Ukraine according to the generally accepted

\footnotetext{
${ }^{5}$ Удова Л.О. Підвищення стійкості виробництва соняшнику. Економіка АПК. 2003. №9. C. 32-37.

6 Лукашев А. И., Тишков Н. М., Лукашев А. А. Новая система применения минеральных удобрений под подсолнечник на выщелоченных черноземах. Науч.-техн. бюлл. ВНИИ масличных культур. Краснодар, 1986. Вып. 1. С. 14-21.

7 Реймов Н. Б., Турдышев Б. Х. Технология возделывания подсолнечника. Аграрна наука. 2003. № 12. С. 10-11.

${ }^{8}$ Пабат I. А., Шевченко М. С. Індустріальна технологія вирощування соняшнику. Вісник аграрної науки. 2004. № 12. С. 16-19.
} 
methods of the experimental work ${ }^{9}$. The experiment was conducted in four replications, the sowing area of the third order plots $-101.6 \mathrm{~m}^{2}$, the accounting area $-50.96 \mathrm{~m}^{2}$. The experimental plot was rectangular, the design of the study was randomized. Complex fertilizers were applied manually using hand-syringe at the stage of 5-6 crop leaves of sunflower.

The economic efficiency of production of the studied crop was defined according to the analysis of the following indexes: yield, production expenditures per the unit of area, the cost of $1 \mathrm{c}$ of seeds, profit per 1 hectare of crops and the level of profitability ${ }^{10}$. To perform calculations on the economic efficiency of the studied elements of the cultivation technology of sunflower hybrids Megasan, Yason and Darii we have taken the stock prices for seeds and market prices for agricultural resources, which were formed during the October of 2016. In the calculation of the energy efficiency the methodology was used.

The calculations have proved that the duration of the inter-stage periods of the studied hybrids of sunflower depended significantly both on their genetic characteristics and current metrological conditions, particularly, on the amount of atmospheric precipitation during the vegetation period of the crop (Table 1).

The longest inter-stage period from the sprouting to the formation of head within 69-78 days was observed in 2015. The shortest one - of 812 days, in all the years of the study was an initial period of the development «sowing-sprouting», and also in the conditions of high temperature regime the shortest inter-stage period was «formation of head - flowering» in 2014, which lasted for 8-13 days.

The vegetation period was the maximum - at the level of 144 days, in 2015 in the hybrid of Megasan, and the shortest - 114 days in the hybrid of Darii in 2016, which is less by $26.3 \%$.

On average for the years of the study, the longest duration of the vegetation period of 134 days was in the hybrid Megasan, and in other studied hybrids this index decreased to $124-130$ days or by $3.3-8.1 \%$.

9 Ушкаренко В. О., Нікішенко В. Л, Голобородько С. П., Коковіхін С. В. Дисперсійний і кореляційний аналіз результатів польових дослідів : монографія. Херсон : Айлант, 2009. 372 с.

${ }^{10}$ Методика определения экономической эффективности использования в сельском хозяйстве результатов научно-исследовательских и опытно-конструкторских работ, новой техники, изобретений и рационализаторских предложений. К.: Урожай, 1986. $117 \mathrm{c}$. 
Table 1

Duration of the inter-stage periods of sunflower hybrids

\begin{tabular}{|c|c|c|c|c|c|c|}
\hline \multirow{2}{*}{$\begin{array}{c}\text { Year/ } \\
\text { Hybrids }\end{array}$} & $\begin{array}{c}\text { Sowing- } \\
\text { sprouting }\end{array}$ & $\begin{array}{c}\text { Sprouting- } \\
\text { formation } \\
\text { of head }\end{array}$ & $\begin{array}{c}\text { Formation } \\
\text { of head- } \\
\text { flowering }\end{array}$ & $\begin{array}{c}\text { Flowering- } \\
\text { ripening }\end{array}$ & $\begin{array}{c}\text { Sprouting- } \\
\text { ripening }\end{array}$ & $\begin{array}{c}\text { Vegetation } \\
\text { period }\end{array}$ \\
\hline \multicolumn{7}{|c|}{2014} \\
\hline Megasan & 9 & 68 & 12 & 47 & 127 & 136 \\
\hline Yason & 11 & 61 & 13 & 46 & 120 & 131 \\
\hline Darii & 11 & 59 & 8 & 47 & 114 & 125 \\
\hline \multicolumn{7}{|c|}{2015} \\
\hline Megasan & 8 & 78 & 22 & 36 & 136 & 144 \\
\hline Yason & 10 & 72 & 24 & 33 & 129 & 139 \\
\hline Darii & 11 & 69 & 21 & 32 & 122 & 133 \\
\hline \multicolumn{7}{|c|}{2016} \\
\hline Megasan & 11 & 52 & 14 & 45 & 111 & 122 \\
\hline Yason & 12 & 49 & 18 & 40 & 107 & 119 \\
\hline Darii & 9 & 51 & 15 & 39 & 105 & 114 \\
\hline \multicolumn{7}{|c|}{ The average for $2014-2016$} \\
\hline Megasan & 9 & 66 & 16 & 43 & 125 & 134 \\
\hline Yason & 11 & 61 & 18 & 40 & 119 & 130 \\
\hline Darii & 10 & 60 & 15 & 39 & 114 & 124 \\
\hline
\end{tabular}

In the variants with different degrees of thickening of the plants and application of microfertilizers, the duration of the inter-stage $\backslash$ periods and the length of the vegetation period was virtually identical, there were found weak trends (for 1-3 days) to acceleration of the ripening of the hybrids at the plants density of 50-60 thousand/ha and, on the contrary, to delaying of the inter-stage periods at the treatment of the crops with microfertilizers, especially in the variant of the treatment with the preparation Master.

On average for the years of the study, the highest level of the plant height - 194.3-199.6 cm - was observed in the variants with hybrid Megasan at the plants density of 50-60 thousand/ha and at application of Vuksal and Master preparations. The smallest $(163.3 \mathrm{~cm})$ figure was in the variant with hybrid Darii at the least plants density of 30 thousand/ha and without application of the complex microfertilizers (Table 2).

Biometric measurements have proved that on the average by the studied factors, the plant height significantly varied depending on the hybrid and to a lesser extent - on the options of plants density and application of microfertilizers. On the average, hybrid Megasan reached the height of $189.8 \mathrm{~cm}$, and hybrids Darii and Yison had the decreased height to 172.4$178.7 \mathrm{~cm}$ or by $6.2-10.1 \%$. 
Table 2

The height of the sunflower plants depending on the hybrid assortment, plants density and microfertilizers at the flowering stage, $\mathrm{cm}$

(the average for 2014-2016)

\begin{tabular}{|c|c|c|c|c|c|c|c|c|}
\hline \multirow{2}{*}{$\begin{array}{c}\text { Hybrid } \\
\text { (Factor } \\
\text { A) }\end{array}$} & \multirow{2}{*}{$\begin{array}{c}\text { Plants } \\
\text { density, } \\
\text { thousan } \\
\text { d/ha } \\
\text { (Factor } \\
\text { B) }\end{array}$} & \multicolumn{5}{|c|}{ Fertilization (Factor C) } & \multirow{2}{*}{$\begin{array}{c}\text { Avera } \\
\text { ge by } \\
\text { the } \\
\text { Factor } \\
\text { A }\end{array}$} & \multirow{2}{*}{$\begin{array}{c}\text { Avera } \\
\text { ge by } \\
\text { the } \\
\text { Facto } \\
\text { r B }\end{array}$} \\
\hline & & $\begin{array}{l}\text { Control } \\
\text { (no } \\
\text { fertilizer) }\end{array}$ & $\begin{array}{c}\text { ROST } \\
- \\
\text { conce } \\
\text { ntrate }\end{array}$ & Vuksal & Master & Average & & \\
\hline \multirow{4}{*}{$\begin{array}{c}\text { Megasa } \\
\mathrm{n}\end{array}$} & 30 & 179.5 & 185.1 & 186.5 & 188.2 & 184.8 & \multirow{4}{*}{189.8} & 176.5 \\
\hline & 40 & 181.8 & 189.9 & 191.4 & 192.7 & 188.9 & & 179.4 \\
\hline & 50 & 182.4 & 192.6 & 194.3 & 196.3 & 191.4 & & 181.6 \\
\hline & 60 & 183.5 & 195.4 & 197.5 & 199.6 & 194.0 & & 183.7 \\
\hline \multirow{4}{*}{ Yason } & 30 & 168.4 & 176.1 & 176.2 & 178.1 & 174.7 & \multirow{4}{*}{178.7} & \\
\hline & 40 & 173.5 & 178.1 & 178.9 & 182.3 & 178.2 & & \\
\hline & 50 & 174.8 & 179.9 & 181.1 & 183.7 & 179.9 & & \\
\hline & 60 & 174.9 & 182.0 & 184.3 & 187.4 & 182.2 & & \\
\hline \multirow{4}{*}{ Darii } & 30 & 163.3 & 171.3 & 171.9 & 173.3 & 169.9 & \multirow{4}{*}{172.4} & \\
\hline & 40 & 166.2 & 170.0 & 172.7 & 175.1 & 171.0 & & \\
\hline & 50 & 167.7 & 174.3 & 176.0 & 176.6 & 173.6 & & \\
\hline & 60 & 168.1 & 175.3 & 177.2 & 179.5 & 175.0 & & \\
\hline \multicolumn{2}{|c|}{$\begin{array}{c}\text { Average by the } \\
\text { Factor C }\end{array}$} & 173.7 & 180.8 & 182.3 & 184.4 & 180.3 & & \\
\hline \multicolumn{9}{|c|}{ The least significant differences $(\mathrm{cm})$ : } \\
\hline \multicolumn{9}{|c|}{ An estimation of the partial differences for the factors: $\mathrm{A}-1.22 ; \mathrm{B}-1.47 ; \mathrm{C}-0.95$} \\
\hline \multicolumn{9}{|c|}{ An estimation of the essential (main) effects: $\mathrm{A}-2.13 ; \mathrm{B}-1.70 ; \mathrm{C}-1.19$} \\
\hline
\end{tabular}

It was established that the increase of the plant density from 30 to 60 thousand/ha caused the proportional increase in the plant height on all the studied hybrids, which can be explained by the aggravation of the competition between the plants for the territory, solar energy, moisture and nutritive substances of the soil. The minimum value $-176.5 \mathrm{~cm}-$ was reached in the variant with the plant density of 30 thousand/ha. With the increase of sowing density up to 40-60 thousand/ha, the plant height in the flowering stage has slightly increased up to $179.4-183.7 \mathrm{~cm}$ or by $1.6-4.1 \%$.

Formation of the indexes of crude biomass was caused by the genetic potential of the studied hybrids, plants density and application of the microfertilizers ROST-concentrate, Vuksal and Master. The maximum value of 31.3-32.2 the studied parameter reached at the cultivation of hybrid Megasan with the plant density of 60 thousand per 1 hectare and at use of microfertilizers Vuksal and Master. The best biomass indexes of hybrids Megasan and Yason were obtained at the plant density of 50-60 thousand/ha, and of hybrid Darii - at the density of 40-60 thousand/ha. 
The analysis of the obtained results on the formation of dry matter depending on the factors and variants of the experiment indicates similar tendencies, which were found during the characteristics of the formation of crude biomass (Table 3 ).

More than 5 tons per 1 hectare of dry matter were obtained in the variant with hybrid Megasan at the plant density of 50 and 60 thousands per hectare and application of the microfertilizers ROST-concentrate, Vuksal and Master. It should be noted that hybrid Megasan was also noticeably different from the other hybrids in the formation of dry matter on the average by the Factor A. On the first of the hybrids, the index increased to $4.4 \mathrm{t} / \mathrm{ha}$, and in the variants with Darii and Yason - the yield of dry matter per the unit of sowing area decreased to $3.49-3.81 \mathrm{t} / \mathrm{ha}$ or by $15.4-26.0 \%$.

The studied range of the plant density had an unequal effect on the formation of the dry matter yield in different hybrids. In particular, at the cultivation of hybrids Megasan and Yason the best results were provided by the density of plants of 50-60 thousand/ha, and in the variant with hybrid Darii the advantageous was the plant density of 50 thousand/ha.

Table 3

The index of the dry matter yield of sunflower at the stage of seed ripening depending on the hybrid assortment, plant density and microfertilizers, $t /$ ha (the average for 2014-2016)

\begin{tabular}{|c|c|c|c|c|c|c|c|c|}
\hline \multirow{2}{*}{$\begin{array}{l}\text { Hybrid } \\
\text { (Factor } \\
\text { A) }\end{array}$} & \multirow{2}{*}{$\begin{array}{c}\text { Plant } \\
\text { density, } \\
\text { thousand/ha } \\
\text { (Factor B) }\end{array}$} & \multicolumn{5}{|c|}{ Fertilization (Factor C) } & \multirow{2}{*}{$\begin{array}{c}\text { Average } \\
\text { by the } \\
\text { Factor } \\
\text { A }\end{array}$} & \multirow{2}{*}{$\begin{array}{c}\begin{array}{c}\text { Average } \\
\text { by the } \\
\text { Factor } \\
\text { B }\end{array}\end{array}$} \\
\hline & & $\begin{array}{c}\text { Control } \\
\text { (no } \\
\text { fertilizers) }\end{array}$ & $\begin{array}{c}\text { ROST- } \\
\text { concentrate }\end{array}$ & Vuksal & Master & Average & & \\
\hline \multirow{4}{*}{ Megasan } & 30 & 3.34 & 3.65 & 3.98 & 4.26 & 3.81 & \multirow{4}{*}{4.40} & 3.53 \\
\hline & 40 & 3.54 & 4.21 & 4.55 & 4.60 & 4.23 & & 3.63 \\
\hline & 50 & 3.90 & 4.55 & 4.81 & 5.11 & 4.59 & & 4.12 \\
\hline & 60 & 4.08 & 5.01 & 5.29 & 5.45 & 4.96 & & 4.31 \\
\hline \multirow{4}{*}{ Yason } & 30 & 3.10 & 3.47 & 3.67 & 3.50 & 3.44 & \multirow{4}{*}{3.81} & \\
\hline & 40 & 3.12 & 3.53 & 3.54 & 3.87 & 3.51 & & \\
\hline & 50 & 3.62 & 3.87 & 4.01 & 4.56 & 4.01 & & \\
\hline & 60 & 3.78 & 4.19 & 4.39 & 4.72 & 4.27 & & \\
\hline \multirow{4}{*}{ Darii } & 30 & 2.87 & 3.24 & 3.34 & 3,51 & 3.22 & \multirow{4}{*}{3.49} & \\
\hline & 40 & 2.89 & 3,37 & 3.38 & 3,60 & 3.26 & & \\
\hline & 50 & 3.36 & 3.62 & 3.96 & 4.16 & 3.77 & & \\
\hline & 60 & 3.32 & 3.56 & 3.88 & 3.98 & 3.70 & & \\
\hline \multicolumn{2}{|c|}{$\begin{array}{c}\text { Average by the Factor } \\
\text { C }\end{array}$} & 3.41 & 3.84 & 4.07 & 4.28 & 3.90 & & \\
\hline \multicolumn{9}{|c|}{ The least significant difference (t/ha): } \\
\hline \multicolumn{9}{|c|}{ An estimation of the partial differences for the factors: $\mathrm{A}-0.49 ; \mathrm{B}-0.68 ; \mathrm{C}-0.55$} \\
\hline \multicolumn{9}{|c|}{ An estimation of the essential (main) effects: $\mathrm{A}-0.27 ; \mathrm{B}-0.21 ; \mathrm{C}-0.39$} \\
\hline
\end{tabular}

Application of microfertilizers significantly increased the yield of dry matter per the unit of sowing area from $3.41 \mathrm{t} / \mathrm{ha}$ in the control variant to 
3.84-4.28 t/ha. It was proved that on the plots where the studied preparations were applied by foliar spraying of the vegetating sunflower plants, the increase in the dry matter yield by $9.0-25.1 \%$ was recorded.

\section{Yield, economic and energy efficiency of the optimized cultivation technology of sunflower hybrids in the conditions of the South of Ukraine}

By the results of the study, it was established that due to the effect of natural factors and, first of all, the difference in the amount of atmospheric precipitation during the vegetation period of sunflower $(2014-174 \mathrm{~mm}$, $2015-240 ; 2016-162 \mathrm{~mm}$ ) there were significant fluctuations in the yields of all the studied hybrids in certain years. In unfavorable 2016, this index decreased to 14.4-16.6 c/ha that is explained by the decrease of water supply of the plants due to the deficit of precipitation and deterioration of growth processes, as well as adverse effect of air drought at the end of the vegetative period.

Plants density also led to significant fluctuations in the productivity of the plants. At the cultivation of the studied crop in 2014, there was an increase in the formation of the maximum level of seed yield (20.6$21.5 \mathrm{c} / \mathrm{ha}$ ) at the plant density of $40-50$ thousand/ha.

In the favorable conditions of 2015, the greatest yield - at the level of 22.1-22.7 c/ha was also obtained at the same plant density. Plant density of 50 thousand/ha was the best, on average by the Factor B, in 2016, when it was obtained $20.7 \mathrm{c} / \mathrm{ha}$. Consequently, in some years, which differed by the level of natural watert supply, the optimum plant density varied slightly by the variants of the experiment. On the contrary, different hybrids had different reaction on thickening, especially hybrid Darii in 2014.

In the years of the study, the efficiency of the complex fertilizers application under the plants of sunflower manifested unequally, however, on average, the positive effect of this agricultural measure, in comparison with the control plots (without treatments), fluctuated in wide range: in $2014-$ 11.5-23.1\%; in $2015-9.2-16.8$; in $2016-12.1-21.9 \%$, respectively. Thus, fertilization played a positive role in all the years of the study, even at worsening of environmental conditions, that is reduced rainfall, increased air temperatures and reduced relative humidity of air.

On average by the years of the study, there was an advantage of the cultivation of hybrid Megasan, which formed an average seed yield of $24.1 \mathrm{c} / \mathrm{ha}$ with the maximum increase to $26.2-27.4 \mathrm{c} / \mathrm{ha}$ at the plant density of 50 thousand/ha and treatment of the crops with the preparations Vuksal and Master (Table 4). 
Table 4

Seed yield of sunflower hybrids depending on the plant density and fertilization, $\mathrm{c} / \mathrm{ha}$ (the average for 2014-2016)

\begin{tabular}{|c|c|c|c|c|c|c|c|c|}
\hline \multirow[b]{2}{*}{$\begin{array}{c}\text { Hybrid } \\
\text { (Factor A) }\end{array}$} & \multirow{2}{*}{$\begin{array}{c}\text { Plant } \\
\text { density, } \\
\text { thousand/ha } \\
\text { (Factor B) }\end{array}$} & \multicolumn{5}{|c|}{ Fertilization (Factor C) } & \multirow[b]{2}{*}{$\begin{array}{l}\text { Average } \\
\text { by the } \\
\text { Factor A }\end{array}$} & \multirow[b]{2}{*}{$\begin{array}{c}\text { Average } \\
\text { by the } \\
\text { Factor B }\end{array}$} \\
\hline & & $\begin{array}{l}\text { Control (no } \\
\text { fertilizers) }\end{array}$ & $\begin{array}{c}\text { ROST- } \\
\text { concent } \\
\text { rate }\end{array}$ & Vuksal & Master & Average & & \\
\hline \multirow{4}{*}{ Megasan } & 30 & 16.8 & 18.1 & 19.6 & 21.4 & 19.0 & \multirow{4}{*}{21.9} & 17.7 \\
\hline & 40 & 19.6 & 22.6 & 23.8 & 25.7 & 22.9 & & 20.7 \\
\hline & 50 & 20.5 & 24.9 & 26.2 & 27.4 & 24.7 & & 21.6 \\
\hline & 60 & 17.8 & 20.9 & 22.5 & 23.1 & 21.1 & & 18.2 \\
\hline \multirow{4}{*}{ Yason } & 30 & 15.6 & 17.6 & 17.3 & 19.3 & 17.4 & \multirow{4}{*}{19.0} & \\
\hline & 40 & 18.2 & 19.3 & 20.0 & 22.9 & 20.1 & & \\
\hline & 50 & 19.0 & 20.9 & 21.9 & 23.7 & 21.4 & & \\
\hline & 60 & 15.7 & 17.3 & 18.3 & 17.6 & 17.2 & & \\
\hline \multirow{4}{*}{ Darii } & 30 & 14.4 & 16.3 & 16.8 & 18.1 & 16.4 & \multirow{4}{*}{17.5} & \\
\hline & 40 & 16.7 & 18.2 & 19.9 & 20.9 & 18.9 & & \\
\hline & 50 & 16.9 & 17.9 & 19.5 & 20.0 & 18.6 & & \\
\hline & 60 & 14.5 & 15.7 & 17.0 & 17.6 & 16.2 & & \\
\hline \multicolumn{2}{|c|}{ Average by the Factor $\mathrm{C}$} & 16.7 & 18.7 & 19.9 & 21.1 & 19.6 & & \\
\hline & $\begin{array}{l}\text { estimation } \\
\text { An estima }\end{array}$ & $\begin{array}{l}\text { The le } \\
\text { the partial } \\
\text { on of the ess }\end{array}$ & $\begin{array}{l}\text { ignific } \\
\text { rences } \\
\text { al (ma }\end{array}$ & $\begin{array}{l}\text { differ } \\
\text { the fac } \\
\text { effects: }\end{array}$ & $\begin{array}{l}\text { (c/ha) } \\
: A-0 \\
-0.27\end{array}$ & $\begin{array}{l}\text { B - } 0 \\
0.21 ;\end{array}$ & $\begin{array}{l}C-0.55 \\
0.39\end{array}$ & \\
\hline
\end{tabular}

Plant density caused significant fluctuations in the plants productivity. Thus, on average, the smallest level of seed yield of all the studied hybrids within 16.2-19.0 c/ha was recorded at the minimum and the maximum density of the plants -30 and 60 thousand/ha. On average by the factor, at the cultivation of hybrids Megasan and Yason, the optimal plant density was 50 thousand/ha, which provided the yields of 24.7 and $21.4 \mathrm{c} / \mathrm{ha}$. In the variant with hybrid Darii, the optimum plant density was 40 thousand/ha, which provided the yield of sunflower seeds $-18.9 \mathrm{c} / \mathrm{ha}$.

Application of the complex fertilizers ROST-concentrate, Vuksal and Master for the improvement of nutrition status had a positive effect on the productivity of all the studied in the experiment hybrids. The largest increase was provided by application of Master with the average yield of $21.1 \mathrm{c} / \mathrm{ha}$, while other fertilization options had the respective decrease by $5.7-11.4 \%$.

Processing of the experimental data by the means of ANOVA allowed defining significant fluctuations in the influence of the studied factors on the level of sunflower yield (Fig. 1). 


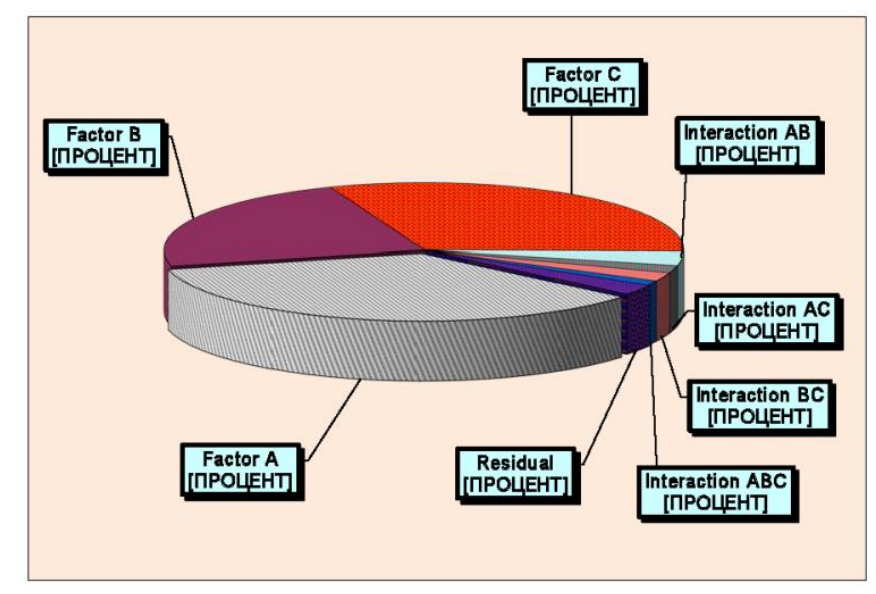

\section{Fig. 1. Share of influence of the factors on the yield of sunflower seeds depending on hybrid assortment (Factor A), plant density (Factor B) and fertilization (Factor $\mathrm{C}$ ), \%}

The greatest effect has the factor A - hybrid assortment, which ensured the formation of yield by $35.1 \%$. Fertilizers application (factor C) provided $31.2 \%$ share in the plant productivity. The share of the effect of plant density (factor B) was also high $-22.9 \%$ that is explained by the change in the reaction of sunflower hybrids on the density of crops.

The interaction of factors, as well as the residual values of the share of the impact was insignificant and fluctuated within 1.1-3.3\% with the maximum advantage of the interaction of factors A and B (hybrid assortment and plant density). During the years of the study, the share of the factors effects was subdivided as follows: Factor A (hybrids) - 35.9, 24.9, 30.8\%; Factor B (plant density) - 23.4, 20.0, 25.0\%; Factor C (fertilization) - 29.8, $40.7,26.4 \%$. Thus, the greatest fluctuations depending on the weather conditions during the vegetation period in certain years of the study from 26.4 to $40.7 \%$ have the complex fertilizers, which were applied for the improvement of nutrition conditions. The interaction of the factors and residual effect of other factors was insignificant (less than 5\%).

Laboratory analysis proved that in the years of the study the content of fat in the seeds of sunflower hybrids fluctuated to varying degrees, which was due to the influence of meteorological factors and the elements of agrotechnology. 
In the conditions of 2014, the maximum fat content in the seed of sunflower at the level of $38.5 \%$ among the studied hybrids was in the seeds of hybrid Megasan at the plant density of 30-40 thousand/ha and treatment of the crops with Vuksal and Master. This index was the minimum in the variants with hybrid Yason (29.6\%) at the plant density of 60 thousand/ha and no fertilizers applied (the control).

In the favorable 2015, the highest index (39.7\%) also was in the first hybrid, but at the plant density of 50 thousand/ha and treatment of the crops with Master.

In the conditions of drought and deficit of natural moisture in the arid 2016 year, there was the increase of the fats content in all the studied hybrids. The highest value of the investigated index within $41.5 \%$ was in hybrid Megasan at the density of the plants of 30 thousand/ha and treatment of the crops with the preparation Master.

On average by the years of the study, fat content in the seeds of sunflower depended considerably on the plant density and fertilization with micronutrient.

Among the studied hybrids, the maximum fat content was provided by hybrids Megasan - 36.9\% and Darii - 35.4\%. In the variant with hybrid Yason, the studied index decreased to 34.3 or by $4.2-7.6 \%$.

Plant density almost did not affect the content of fat, and the difference between the variants was less than the $\mathrm{LSD}_{05}$ for this factor $(0.89 \%)$ with the fluctuations of $0.8-3.8 \%$. Some tendency to the reduction of fat content in the seeds at the plan density of 60 thousand/ha could be explained by the deterioration of the nutrients and moisture supply during the growth under the increased competition in the thickened crops.

In the variant without microfertilizers application, the average fat content in the seeds of the studied crop was 33.3\%, and under the fertilization of the vegetating plants with the preparations ROST-concentrate, Vuksal and Master - increased to $34.7-37.7 \%$ or by $4.2-13.2 \%$.

The years of the study differed by natural moisture supply, which significantly affected not only the biometric parameters of the plants and yields, but also the quality indexes, particularly, the efficiency of the complex fertilizers application under the plants of sunflower. The conditional yield of oil per 1 hectare of the sowing area of sunflower in 2014 depended on the hybrid assortment, plant density and fertilization, the maximum index was $1030.9 \mathrm{~kg} / \mathrm{ha}$ in hybrid Megasan at the density of the plants of 50 thousand/ha and treatment of the crops with the preparation Master. The minimum values of the index were fixed in hybrid Darii $(437.8 \mathrm{~kg} / \mathrm{ha})$ at the maximum density -60 thousand/ha. 
Under the favorable meteorological conditions of 2015, the conditional yield of oil per one hectare of the sowing area reached the greatest values on all the hybrids, all he variants of the plants thickening and fertilization with the micronutrients. The maximum - at the level of $1118.6 \mathrm{~kg} / \mathrm{ha}$ was recorded in hybrid Megasan at the plant density of 50 thousand/ha and treatment of the crops with the preparation Master, and its lowest level $(544.1 \mathrm{~kg})$ was fixed on the untreated with the microfertilizers variants in hybrid Darii at the density of 30 thousand/ha.

Under the arid conditions of 2016 we received the lowest conditional yield values per 1 hectare of the sowing area at the level of $394.1-453.5 \mathrm{~kg}$ in the variants with hybrid Darii, the plant density of 60 thousand/ha and without application of the microfertilizers.

On average for the years of the study, a conditional yield of oil per 1 hectare of the sunflower sowing area depended on the cultivated hybrid, plant density and fertilization with the maximum index of $1077.8 \mathrm{~kg}$ in hybrid Megasan at the density of the plants of 50 thousand/ha and treatment of the crops with Master (Table 5). The lowest value of the investigated index of only $463.1 \mathrm{~kg} / \mathrm{ha}$ was fixed in hybrid Darii at the density of the plants of 60 thousand/ha and without application of the microfertilizers.

Table 5

Conditional yield of oil per 1 hectare of the sunflower sowing area depending on the hybrid assortment, plant density and fertilization,

$\mathrm{kg}$ (the average for 2014-2016 years)

\begin{tabular}{|c|c|c|c|c|c|c|c|c|}
\hline \multirow[b]{2}{*}{$\begin{array}{c}\text { Hybrid } \\
\text { (Factor } \\
\text { A) }\end{array}$} & \multirow{2}{*}{$\begin{array}{c}\text { Plant } \\
\text { density, } \\
\text { thousand/ha } \\
\text { (Factor B) }\end{array}$} & \multicolumn{5}{|c|}{ Fertilization (Factor C) } & \multirow{2}{*}{$\begin{array}{c}\begin{array}{c}\text { Average } \\
\text { by the } \\
\text { Factor } \\
\text { A }\end{array} \\
\end{array}$} & \multirow{2}{*}{$\begin{array}{c}\text { Average } \\
\text { by the } \\
\text { Factor } \\
\text { B } \\
\end{array}$} \\
\hline & & $\begin{array}{c}\text { Control } \\
\text { (no } \\
\text { fertilizers) }\end{array}$ & $\begin{array}{c}\text { ROST- } \\
\text { concentrate }\end{array}$ & Vuksal & Master & Average & & \\
\hline \multirow{4}{*}{ Megasan } & 30 & 581.7 & $\begin{array}{l}654.8 \\
\end{array}$ & 772.8 & 842.3 & 712.9 & \multirow{4}{*}{812.3} & 640.3 \\
\hline & 40 & 683.6 & 812.0 & 915.8 & 1010.6 & 855.5 & & 744.2 \\
\hline & 50 & 712.1 & 902.2 & 975.1 & 1077.8 & 916.8 & & 771.2 \\
\hline & 60 & 588.6 & 747.9 & 849.0 & 870.2 & 763.9 & & 629.6 \\
\hline \multirow{4}{*}{ Yason } & 30 & 513.1 & 600.7 & 635.3 & 711.0 & 615.0 & \multirow{4}{*}{654.8} & \\
\hline & 40 & 591.9 & 651.8 & 719.7 & 828.5 & 698.0 & & \\
\hline & 50 & 612.9 & 688.4 & 777.3 & 862.1 & 735.2 & & \\
\hline & 60 & 487.6 & 552.1 & 619.5 & 624.6 & $\begin{array}{l}571.0 \\
\end{array}$ & & \\
\hline \multirow{4}{*}{ Darii } & 30 & 487.1 & 578.3 & 621.2 & 685.8 & 593.1 & \multirow{4}{*}{622.0} & \\
\hline & 40 & 560.9 & 638.0 & 732.6 & 784.5 & 679.0 & & \\
\hline & 50 & 566.3 & 623.3 & 692.6 & 764.6 & 661.7 & & \\
\hline & 60 & 463.1 & 523.5 & 577.1 & 652.4 & 554.0 & & \\
\hline \multicolumn{2}{|c|}{$\begin{array}{c}\text { Average } \\
\text { by the Factor } \mathrm{C}\end{array}$} & 570.8 & 664.4 & 740.7 & 809.5 & 696.3 & & \\
\hline
\end{tabular}

By the first studied factor (hybrid assortment), the advantage of hybrid Megasan, which allowed obtaining in average $812.3 \mathrm{~kg} / \mathrm{ha}$ of sunflower oil, 
was proved. On hybrids Darii and Yason, these figures ranged from 622.0 to $654.8 \mathrm{~kg} / \mathrm{ha}$, which is less than the Megasan by $24.1-30,6 \%$, respectively.

Plant density to different extent affected the conditional yield of oil per the unit of sowing area. Thus, in the variant with hybrid Megasan, the greatest level of the studied index $(916.8 \mathrm{~kg} / \mathrm{ha})$ was provided by the density of the plants of 50 thousand/ha; on hybrids Yason $(698.0-735.2 \mathrm{~kg} / \mathrm{ha})$ and Darii (661.7-679.0 kg/ha) - 40-50 thousand/ha.

On average by the plant density (Factor B), the greatest yield of conditional oil $-771.2 \mathrm{~kg} / \mathrm{ha}$ was provided by the density of the plants 50 thousand/ha. At the density of the plants of 40 thousand/ha there was an insignificant decrease in the index to $744.1 \mathrm{~kg} / \mathrm{ha}$ or by $3.4 \%$. The boundary range of the crops thickening (30 and 60 thousand/ha) resulted in a significant - by $20.4-22.5 \%$ - reduction in the conditional yield of sunflower oil per the area of the research plots.

Application of the microfertilizers (ROST-concentrate, Vuksal, Master) in the recommended doses caused a significant increase in the conditional yield of oil per 1 hectare. On the untreated plots, this index was $570.8 \mathrm{~kg} / \mathrm{ha}$, and under the use of the fertilizers we recorded its rise to $664.4-809.5 \mathrm{~kg} / \mathrm{ha}$ or by $16.4-41.8 \%$.

The studied factors significantly affected on the cost of the gross product, which increased over 20 thousand/ha at the cultivation of all the studied hybrids with the density of the plants in the range of 40-60 thousand/ha and treatment with the complex fertilizers ROST-concentrate, Vuksal and Master. The lowest values of this index fluctuated from 14.0 to 17.4 thousand $\mathrm{UAH} / \mathrm{ha}$ at the minimum density of the plants (30 thousand/ha) and without application of the complex fertilizers.

Fertilization of sunflower with the complex fertilizer Master contributed to the increase of the value of the gross product per the unit of area, on average, up to 20.6 thousand/ha. In the variant with the treatment of the plants with Vuksal, this index decreased by 5.7\%, and in the areas where the ROST-concentrate was applied - by $11.4 \%$. On the whole, application of the complex fertilizers on the crops provided the increase of the gross yields by $10.7-20.9 \%$ in comparison to the control plots

By the analysis of technological maps of the cultivation of sunflower hybrids Megasan, Yason and Darii on the research plots, it was proved that the production expenditures did not change significantly depending on the change of the plant density and the use of the complex fertilizers ROSTconcentrate, Vuksal and Master.

The highest production expenditures of more than 9.6 thousand $\mathrm{UAH} / \mathrm{ha}$ were fixed in the variants with hybrid Megasan at the density of the plants of 
50-60 thousand/ha and application of the complex fertilizers Vuksal and Master, and on hybrid Yason - with the same thickening and use of Vuksal.

The calculations helped us to determine that the lowest cost of $1 \mathrm{c}$ of sunflower seeds at the level of $350.4 \mathrm{UAH}$ was in the variant with hybrid Megasan, the plant density of 50 thousand/ha and treatment of the crops with the complex fertilizer Master. The highest (at the level of $629.5 \mathrm{UAH} / \mathrm{v}$ ) figure was obtained in the variant with hybrid Darii at the density of the plant of 60 thousand/ha and without the use of the complex fertilizers.

Among the hybrids, the highest level of sunflower seeds cost had hybrids Darii and Yason, where this index increased to 532.2 and $491.9 \mathrm{UAH} / \mathrm{c}$, respectively. At the cultivation of hybrid Megasan, this index decreased by 19.5 and $12.9 \%$ - to $428.2 \mathrm{UAH} / \mathrm{c}$, which indicates the best use of monetary resources at the cultivation of this hybrid.

The maximum pure profit at the level of 17.1 thousand UAH was obtained in the variant with hybrid Megasan at the sowing with the density of 50 thousand/ha and carrying out applications with the complex fertilizer Master (Table 7).

Among the studied hybrids, Megasan also had an advantage from the point of view of the forming the largest conditional pure profit. Thus, in the variant with this hybrid, this index was, on average by the factor A, 11,975 UAH/ha, and in the variants with hybrids Darii and Yason it decreased to 7,749-9,180 UAH/ha or by 23.3-35.3\%.

Application of all the studied complex fertilizers contributed to significant (by 20.2-35.1\%) increase in the pure profit at the cultivation of hybrids Megasan, Yason and Darii. In the control variant, the minimum value of the studied index was observed - at the level of 7.2 thousand $\mathrm{UAH} / \mathrm{ha}$. The biggest pure profit was in the variant with application of the preparation Megasan, where it increased to 11.1 thousand $\mathrm{UAH} / \mathrm{ha}$, which is 1.5 times more comparing with the control variant.

The profitability level of more than $160 \%$ was observed in the variants with hybrid Megasan at the density of the plants of 40-50 thousand/ha and application of the complex fertilizers ROST-concentrate, Vuksal and Master. And the highest profitability $(178.3 \%)$ was formed at the cultivation of hybrid Megasan with the density of the plants of 50 thousand/ha and application of the complex fertilizer Master.

The gross energy income from the seed yield depended on the fluctuations in the seed yield under the influence of the studied factors - the hybrid assortment (Factor A), the plant density (Factor B), fertilization (Factor C). Among the hybrids of sunflower, the greatest energy output per the unit of area was provided at the cultivation of hybrid Megasan, where the index was $53.0 \mathrm{GJ} / \mathrm{ha}$. 
In hybrids Yason and Darii there was a decrease in the energy income with the seed yield to 45.9 and $42.3 \mathrm{GJ} / \mathrm{ha}$, or by 13.2 and $20.1 \%$.

Table 7

Pure profit received from the cultivation of sunflower depending
on the hybrid assortment, density of the plants and fertilization, UAH/ha (the average for 2014-2016)

\begin{tabular}{|c|c|c|c|c|c|c|c|c|}
\hline \multirow[b]{2}{*}{$\begin{array}{c}\text { Hybrid } \\
\text { (Factor A) }\end{array}$} & \multirow[b]{2}{*}{$\begin{array}{c}\text { Plant } \\
\text { density, } \\
\text { thousand/ha } \\
\text { (Factor B) }\end{array}$} & \multicolumn{5}{|c|}{ Fertilization (Factor C) } & \multirow[b]{2}{*}{$\begin{array}{c}\text { Average } \\
\text { by the } \\
\text { Factor A }\end{array}$} & \multirow[b]{2}{*}{$\begin{array}{c}\text { Average } \\
\text { by the } \\
\text { Factor } B\end{array}$} \\
\hline & & $\begin{array}{l}\text { Control } \\
\text { (no } \\
\text { fertilize } \\
\text { rs) }\end{array}$ & $\begin{array}{c}\text { ROST- } \\
\text { concent } \\
\text { rate }\end{array}$ & Vuksal & Master & Average & & \\
\hline \multirow{4}{*}{ Megasan } & 30 & 7,378 & 8,520 & 9,640 & 11,455 & 9,273 & \multirow{4}{*}{11,975} & 8,030 \\
\hline & 40 & 9,995 & 12,794 & 13,622 & 15,535 & 12,962 & & 10,847 \\
\hline & 50 & 10,795 & 14,959 & 15,884 & 17,114 & 14,639 & & 11,652 \\
\hline & 60 & 8,158 & 11,055 & 12,273 & 12,918 & 11,125 & & 8,335 \\
\hline \multirow{4}{*}{ Yason } & 30 & 6,233 & 8,057 & 7,423 & 9,433 & 7,738 & \multirow{4}{*}{9,180} & \\
\hline & 40 & 8,659 & 9,606 & 9,946 & 12,834 & 10,261 & & \\
\hline & 50 & 9,363 & 11,090 & 11,723 & 13,538 & 11,453 & & \\
\hline & 60 & 6,154 & 7,588 & 8,221 & 7,598 & 7,366 & & \\
\hline \multirow{4}{*}{ Darii } & 30 & 5,088 & 6,815 & 6,960 & 8,288 & 6,788 & \multirow{4}{*}{7,749} & \\
\hline & 40 & 7,228 & 8,564 & 9,880 & 10,915 & 9,122 & & \\
\hline & 50 & 7,359 & 8,208 & 9,426 & 9,973 & 8,766 & & \\
\hline & 60 & 5,010 & 6,054 & 6,979 & 7,624 & 6,417 & & \\
\hline \multicolumn{2}{|c|}{$\begin{array}{l}\text { Average by the } \\
\text { Factor C }\end{array}$} & 7,188 & 9,012 & 9,840 & 11,070 & 9,765 & & \\
\hline
\end{tabular}

According to the calculations, it was proved that the consumption of gross energy on sunflower seed production was poorly influenced by the studied factors, due to the insignificant difference between the individual technological operations and expenditure of resources on the individual variants of the cultivation technologies.

For the formation of the yield, hybrid Megasan used $18.4 \mathrm{GJ} / \mathrm{ha}$, and at the cultivation of hybrids Yason and Darii, this index decreased insignificantly (by 0.8-1.2\%) - to 18.1-18.2 GJ/ha. The maximum energy increase at the level of 34.6 GJ/ha was in the variant with hybrid Megasan, and in other hybrids this index decreased to $24.2-27.7 \mathrm{GJ} / \mathrm{ha}$, or by $19.8-30.1 \%$.

The maximum coefficient of energy efficiency (more than 3.0) in the experiment was in the variant with hybrid Megasan at the plant density of 40-60 thousand/ha and application of the complex fertilizers ROSTconcentrate, Vuksal and Master.

The analysis of the energy intensity for the production of $1 \mathrm{c}$ of sunflower seeds allowed to detremine a tendency to the reduction of this index to $0.68-0.72 \mathrm{GJ}$ at the cultivation of hybrid Megasan with the plant density of 40-50 thousand/ha and application of the complex fertilizers Vuksal and Master. 
The developed dependencies testify about the necessity for an energy substantiation of sunflower seed cultivation technologies depending on the hybrid assortment and the individual elements of cultivation technology, in particular, plant density and complex fertilizers application. Consequently, at the cultivation of hybrids with high genetic potential, it is needed to plan higher energy expenditures, which will subsequently be fully compensated by the increased yield of seeds.

\section{CONCLUSIONS}

1. By the results of the field study it was established that the highest duration of the vegetation period of 134 days was in hybrid Megasan, and in other studied hybrids, this index decreased to $124-130$ days or by $3.3-8.1 \%$. Plant height of the maximum level $-194.3-199.6 \mathrm{~cm}$ was reached on the plots with hybrid Megasan, which was cultivated with the density of 5060 thousand of the plants per 1 hectare and treatment of the crops with Vuksal and Master. The maximum output of crude biomass at the level of 31.3-32.2 t/ha was recorded at the cultivation of hybrid Megasan at the plant density of 60 thousand/ha and with application of the microfertilizers Vuksal and Master. The same hybrid provided the yield of dry matter that averaged to $4.4 \mathrm{t} / \mathrm{ha}$, and in the variants with hybrids Darii and Yason it decreased by 15.4-26.0\%.

2. The study have determined that at the cultivation of sunflower on dark-chestnut soil in the non-irrigated conditions of the South of Ukraine it is necessary to adjust the density of plants depending on the genetic potential of hybrids. To obtain the yield at the level of $23-25 \mathrm{c} / \mathrm{ha}$ it is required to sow the hybrid Megasan. The density of plants should be adjusted depending on the genetic potential of the hybrids - for hybrids Megasan and Yason the optimal density is 50 thousand/ha, and for hybrid Darii - 40 thousand/ha. Treatment of sunflower crops with the complex fertilizers provides the increase in the yield by $10.7-20.9 \%$, improves seed quality, positively reflects on the economic indicators.

3. The lowest cost of $1 \mathrm{c}$ of sunflower seed at the level of $350.4 \mathrm{UAH}$ was in the variant with hybrid Megasan, the plant density of 50 thousand/ha and treatment of the crops with the complex fertilizer Master. The level of profitability of more than $160 \%$ was fixed in the variants with hybrid Megasan at the plant density of 40-50 thousand/ha and application of the complex fertilizers ROST-concentrate, Vuksal and Master. The analysis of the energy intensity for $1 \mathrm{c}$ of sunflower seeds production allowed to determine the tendency to the reduction of this index to $0.68-0.72 \mathrm{GJ}$ at the 
cultivation of hybrid Megasan with the density of the plants of 4050 thousand/ha and application of the complex fertilizers Vuksal and Master.

\section{SUMMARY}

The article presents the results of the study on the dynamics of the indexes of production processes of sunflower hybrids depending on the differentiation of the plant density and the background of fertilization with the complex microfertilizers. It was determined that the length of the inter-stage periods of the studied sunflower hybrids significantly depended on their genetic characteristics and current metrological conditions, in particular, on the amount of atmospheric precipitation during the vegetation period of the crop. The formation of crude biomass indexes was determined by genetic potential of the studied hybrids, the density of the plants and application of microfertilizers ROST-concentrate, Vuksal and Master. The results of the field study determined that the longest duration of the vegetation period at the level of 134 days was in hybrid Megasan, and in other hybrids this index decreased to $124-130$ days or by $3.3-8.1 \%$. The maximum yield of crude biomass at the level of 31.3-32.2 t/ha was recorded at the cultivation of hybrid Megasan with the density of the plants of 60 thousand/ha and application of Vuksal and Master. The same hybrid provided the yield of dry matter at the level of 4.4 t/ha, and in the variants with hybrids Darii and Yason it decreased by 15.4$26.0 \%$. The highest yield of sunflower seeds at the level of 23-25 c/ha provided hybrid Megasan. The optimum plant density for hybrids Megasan and Yason is 50 thousand/ha, and for hybrid Darii - 40 thousand/ha. Application of the complex fertilizers on sunflower crops provides the yield increase by $10.7-20.9 \%$ and improves seed quality. Economic and energy indexes testify about high level of pure profit (10.9-17.1 thousand UAH/ha), profitability (115-178\%) and the energy coefficient (2.76-3.55) at the cultivation of the seeds of the studied crop.

\section{REFERENCES}

1. Адаменко Т. Перспективи виробництва соняшнику в Україні в умовах зміни клімату. Агроном. 2005. №1. С. 12-14.

2. Ушкаренко В. О., Лазер П. Н., Шепель А. В. Економічна та біоенергетична ефективність вирощування соняшника різних груп стиглості в основних посівах при зрошенні. Таврійський науковий вісник. 1998. Вип. 8. С. 10-15.

3. Методика проведения полевых агротехнических опытов с масличными культурами / под общей редакцией В. М. Лукомца. Краснодар, 2007. С. 122-129. 
4. Миронова Н. М. Напрямки зниження та шляхи вдосконалення структури виробничих витрат. Таврійський науковий вісник. 2006. Вип. 44. С. 326-333.

5. Удова Л.О. Підвищення стійкості виробництва соняшнику. Економіка АПК. 2003. №9. С. 32-37.

6. Лукашев А. И., Тишков Н. М., Лукашев А. А. Новая система применения минеральных удобрений под подсолнечник на выщелоченных черноземах. Науч.-техн. бюлл. ВНИИ масличных культур. Краснодар, 1986. Вып. 1. С. 14-21.

7. Реймов Н. Б., Турдышев Б. Х. Технология возделывания подсолнечника. Аграрна наука. 2003. № 12. С. 10-11.

8. Пабат I. А., Шевченко М. С. Індустріальна технологія вирощування соняшнику. Вісник аграрної науки. 2004. № 12. С. 16-19.

9. Ушкаренко В. О., Нікішенко В. Л, Голобородько С. П., Коковіхін С. В. Дисперсійний i кореляційний аналіз результатів польових дослідів : монографія. Херсон : Айлант, 2009. 372 с.

10. Методика определения экономической эффективности использования в сельском хозяйстве результатов научноисследовательских и опытно-конструкторских работ, новой техники, изобретений и рационализаторских предложений. К.: Урожай, 1986. $117 \mathrm{c}$.

\section{Information about the Author:} Nesterchuk V. V.,

Candidate (Ph.D.) of Agricultural Sciences, Director, State Enterprise Research Farm «Kopani» of the Institute of Irrigated Agriculture of the National Academy of Agrarian Sciences of Ukraine Petrivske Village, Kherson Region, 75011, Ukraine 


\section{YEARLY AND OPERATION PLANNING OF THE IRRIGATION REGIMES OF THE MAIN CROPS}

\section{Pysarenko P. V.}

\section{INTRODUCTION}

Irrigated agriculture is a complex multifunctional system in which the main role is played by soil fertility, structure of sown areas, genetic characteristics of varieties, their adaptability to the conditions of cultivation, organic and mineral fertilizers, plant protection products, modern technologies of crops cultivation, etc. ${ }^{1,2}$. The use of scientifically substantiated components of the system of agriculture on the irrigated lands ensures and optimizes the use of natural factors and, first of all, water resources $^{3}$. An important element in these interrelated factors is the irrigation regime, the main task of which is to enhance the effects of other factors in the direction of obtaining high yield and pure profit from irrigation ${ }^{4,5}$.

In the practice of irrigated agriculture, several methods are used to determine the time and norms of vegetation watering, which differ in the degree of reliability, the labor-intensiveness of gathering information, the expenses of time and cost for the obtaining of the necessary results ${ }^{6}$. However, the use of any of the methods provides more reliable data than the irregular use of irrigation according to general recommendations ${ }^{7}$.

\footnotetext{
${ }^{1}$ Авдеев Ю. И. Рекомендации по возделыванию сельскохозяйственных культур при капельном орошении. М.: Изд. МСХ РФ, 2003. 46 с.

${ }^{2}$ Балюк С. А., Ромащенко М. І. Наукові аспекти сталого розвитку зрошення земель в Україні. К. : ДІА, 2006. 32 с.

${ }^{3}$ Писаренко П. В., Вожегова Р. А., Лавриненко Ю. О., Коковіхін С. В. Вимоги сільськогосподарських культур до режиму зрошення. Посібник украӥнського хлібороба. 2011. C. 95-100.

${ }^{4}$ Жовтоног О. І., Філіпенко Л. А., Шостак І. К., Поліщук В. В. Сучасна концепція та методи управління зрошенням на рівні господарства в умовах недостатнього зволоження. Наукові основи землеробства в умовах недостатнього зволоження. К., 2001. С. 89-92.

5 Жуйков Г. Є. Економічні засади ведення землеробства на зрошуваних землях. Херсон : Айлант, 2003. 288 с.

${ }^{6}$ Кириенко Т. Н., Остапчик В. П., Жовтоног О. И. Основные принципы разработки почвозащитных режимов орошения. Орошаемые черноземы и их рациональное использование. Новочеркасск: НПО «Мелиорация», 1990. С. 85-92.

7 Латифов Н. Л., Кобозев И. В., Парахин Н. В. Оптимизация режимов орошения сельскохозяйственных культур. М. : МСХА, 1996. 94 с.
} 
The South of Ukraine has lost its status as a new irrigation area long ago, because in this region for the last half of a century a large number of special studies have been conducted to determine the actual moisture uptake by phytocenosis by the scientific institutions, and first of all, Institute of Irrigated Agriculture of NAAS ${ }^{8}$.

\section{Formation of the actual irrigation regime of crops depending on the natural and economic conditions of farms}

Irrigation regime is one of the key elements of the system of irrigated agriculture and crop cultivation technology. This is a complex indicator that consists of determination and distribution in time of the number and norms of watering for crops in dependence on their biological characteristics, the reaction to the lack of moisture at different stages of plant organogenesis, meliorative conditions of the irrigated areas, irrigation water quality, irrigation methods, climate of the zone and weather conditions of the vegetative period ${ }^{9}$. Irrigation regime should provide an optimization of the water regime of soil and phytoclimate of crops, exclusion of gravitational losses of water beyond the active soil layer, promotion of the most complete use of the bioclimatic potential of the zone and soil fertility, genetic capabilities of varieties, fertilizers, and plant protection products, etc. In modern amelioration and agricultural science and practice, several approaches are applied to the formation of irrigation regimes, which are combined into following types of irrigation regimes: optimal, water-saving and soil-protective ${ }^{10}$.

The optimal irrigation regimes are directed to the continuous supply of plants with water throughout the whole vegetation by maintaining the optimal soil moisture through irrigation and creating the conditions for realizing the potential level of water consumption of the crop $^{3}$. While observing the whole range of technological measures for cultivation of crops and environmental requirements for the volumes of irrigation norms on a specific irrigated array, optimal irrigation regimes guarantee the maximum yield addition due to the irrigation and elimination of irrigation water losses

\footnotetext{
${ }^{8}$ Льгов Г. К., Адиньяев Э. Д. Водопотребление и режим орошения кукурузы. Агробиологическое обоснование поливного режима и применение удобрений под кукурузу. Тр. Горского СХИ. 1974. С. 3-37.

${ }_{9}$ Методические указания по применению биофизического метода для определения эффективных запасов влаги в почве м сроков полмва сельскохозяйственных культур. Херсон: $1975.77 \mathrm{c}$.

${ }^{10}$ Писаренко В. А., Коковіхін С. В., Іванов І. Т., Тищенко О. П., Мішукова Л. С. та ін. Методичні рекомендації по застосуванню водозберігаючих режимів зрошення сільськогосподарських культур. Херсон : Айлант, 2002. 32 с.
} 
for infiltration beyond the root-containing soil layer ${ }^{11}$. In the recent past, these irrigation regimes have been major ones in the irrigated agriculture of Ukraine. Currently, they are mainly used in farms that are sufficiently provided with financial, water and material and technical resources and plan to receive the highest yields from the whole area or its part where the most economically profitable crops are cultivated ${ }^{8}$.

Water-saving irrigation regimes, developed at the Institute of Irrigated Agriculture under the leadership of V.A. Pysarenko, together with the specialists of the Institute of Water Problems and Land Reclamation of the NAAS, nowadays are the main type of irrigation regime that is being introduced into production ${ }^{12,13,14}$.

The theoretical concept of water-saving irrigation regimes is based on the analysis of long-term research on the questions of crop irrigation, which shows that there is a disproportionate dependence between the level of plant yield, total water consumption and irrigation rate. Increase in yield per unit of irrigation water increases with irrigation rate to a certain limit, and further decreases and even reaches zero or negative values. Thus, the share of individual irrigation in the formation of additional yield from irrigation is not equal and this must be taken into account in practical activities ${ }^{8,12}$.

The Institute of Irrigated Agriculture has conducted for many years researches on 4 irrigation systems (Ingulets, Danube-Dnistrovsk, Rozdolnenska and Frunzenska) concerning the comparison of the efficiency of the application of optimal and water-saving irrigation regimes (Table 1). These irrigation systems differ in the quality of irrigation water, the physical and chemical properties of soils and the climate, as they are located in different zones of the Steppe. Therefore, the results of the studies are representative for the entire Steppe region. They indicate that the use of water-saving irrigation regimes provides a significant reduction in irrigation water expenditures for all crops at insignificant yield losses, compared to optimal irrigation. In the conditions of Southern Steppe, cereals, soybean, alfalfa and potato, which at the decrease of the irrigation norm by

11 Писаренко В. А. Методичні підходи до формування водозберігаючих режимів зрошення культур у степовому регіоні. Наукові основи землеробства в умовах недостатнього зволоження: Матер. наук.-практ. конф. 21-23 лютого 2000 р. К.: Аграрна наука, 2001. С. 181-189.

Писаренко В. А. Особливості планування режимів зрошення сільськогосподарських культур в умовах дефіциту водно-енергетичних ресурсів. Актуальні проблеми ефективного використання зрошуваних земель. Сб. наук. праць ін-т. зрошув. землер. Херсон, 1999. № 2. С. 8-12.

${ }_{13}$ Розгон В. А. Оптимізація водного балансу зрошуваних територій. Зрошуване землеробство. 2002. №3. С. 87.

${ }_{14}$ Ромащенко М. І., Балюк С. А. Зрошення земель в Україні. Стан та шляхи поліпшення. К. : Світ, 2000. $114 \mathrm{c.}$ 
19.1-41.8\% almost do not lose their yields, react most positively to the application of water-saving regimes of irrigation.

Soil-protective regimes of irrigation are applied in case of poor meliorative, ecological and soil conditions of the irrigated array ${ }^{15,16}$.

Table 1

Comparative evaluation of different types of irrigation regimes on the studied areas (the materials of the Department of Irrigated Agriculture of the Institute of Irrigated Agriculture of NAAS)

\begin{tabular}{|c|c|c|c|c|c|}
\hline \multirow{2}{*}{$\begin{array}{c}\text { Crop and a } \\
\text { number of the } \\
\text { years of the } \\
\text { study }\end{array}$} & \multirow{2}{*}{$\begin{array}{c}\text { Irigation } \\
\text { regime model }\end{array}$} & \multirow{2}{*}{$\begin{array}{c}\text { Average } \\
\text { irrigation } \\
\text { norm, } \\
\text { m}^{3} / \mathbf{h a}\end{array}$} & \multirow{2}{*}{$\begin{array}{c}\text { Yield, } \\
\text { t/ha }\end{array}$} & \multicolumn{2}{|c|}{$\begin{array}{l}\text { The ratio of water- } \\
\text { saving irrigation indexes } \\
\text { to the optimal one, } \%\end{array}$} \\
\hline & & & & $\begin{array}{c}\text { Decrease } \\
\text { of yield }\end{array}$ & $\begin{array}{l}\text { Water } \\
\text { saving }\end{array}$ \\
\hline \multirow{2}{*}{$\begin{array}{c}\text { Winter wheat } \\
\text { (9) }\end{array}$} & Optimal & 1605 & 5.68 & & \\
\hline & Water-saving & 1317 & 5.76 & +1.4 & 19.9 \\
\hline \multirow{2}{*}{$\begin{array}{l}\text { Corn for grain } \\
\text { (16) }\end{array}$} & Optimal & 2220 & 9.46 & & \\
\hline & Water-saving & 1520 & 9.09 & 3.9 & 31.5 \\
\hline \multirow{2}{*}{ Soybean (6) } & Optimal & 2840 & 3.27 & & \\
\hline & Water-saving & 2450 & 3.25 & 0.6 & 13.7 \\
\hline \multirow{2}{*}{ Sugar-beet (9) } & Optimal & 2470 & 64.4 & & \\
\hline & Water-saving & 1930 & 61.9 & 3.9 & 22.1 \\
\hline \multirow{2}{*}{$\begin{array}{c}\text { Alfalfa for } \\
\text { green forage } \\
\text { for three years } \\
\text { of the use ( } 3 \\
\text { cycles) }\end{array}$} & Optimal & 9800 & 152.6 & & \\
\hline & Water-saving & 6860 & 145.3 & 4.8 & 30.0 \\
\hline \multirow{2}{*}{$\begin{array}{l}\text { Alfalfa for } \\
\text { green forage } \\
\text { for three years } \\
\text { of the use }(7)\end{array}$} & Optimal & 4490 & 66.2 & & \\
\hline & Water-saving & 2890 & 63.7 & 3.8 & 35.6 \\
\hline \multirow{2}{*}{ Mangel (8) } & Optimal & 3300 & 159.8 & & \\
\hline & Water-saving & 2700 & 152.9 & 4.3 & 18.2 \\
\hline \multirow{2}{*}{$\begin{array}{c}\text { Corn for silage } \\
\text { (9) }\end{array}$} & Optimal & 1990 & 74.6 & & \\
\hline & Water-saving & 1640 & 74.2 & 0.5 & 17.6 \\
\hline \multirow{2}{*}{$\begin{array}{c}\text { Early potato } \\
(6)\end{array}$} & Optimal & 1800 & 23.4 & & \\
\hline & Water-saving & 1420 & 23.3 & 0.4 & 20.6 \\
\hline
\end{tabular}

They differ in economy of irrigation and on the background of other agro-ameliorative measures for conservation and recovery of soil fertility perform soil-protective function and ensure the balance of natural processes in agro-ecological systems.

15 Ромащенко М. І., Жовтоног О. І., Філіпенко Л. А., Деменкова Т. Ф. Методика планування оптимальних екологічно безпечних режимів зрошення. К. : УкрНИИГиМ, 1997. C. 43.

${ }_{16}$ Справочная книга по орошаемому земледелию. Общая ред.: Погребняк А.П., Калашников К.Г. Кишинев: Картя Молдовеняскэ. 1990. 134 с. 
In accordance with the direction and quantitative characteristics of changes in soil and ecological conditions of land under soil-protective regimes of irrigation, it is proposed to apply limits on irrigation rates, terms of their application and quality of irrigation water. As concerning the irrigation limits, they should only humidify the soil layer in which the most quantity of roots is concentrated. The terms of irrigation, in general, should be planned for the critical periods of plant development, when the maximum yield from their use is observed. Of course, degraded soils should be discarded from the use of low quality irrigation water. Comparing the requirements for soil-protective and water-saving irrigation regimes, they are the same in many parameters they and, therefore, the latter can be applied to degraded soils, under the condition of application of some adjustments.

Thus, it is practically impossible to find an alternative to the watersaving model of the crop irrigation regime in the current economic conditions. Formation of a regime of irrigation of a specific crop is divided into two stages: norms;

- the first - preliminary planning of terms, watering and irrigation

- second - the operation management of the irrigation regime during the irrigation season, taking into account the initial moisture reserves, weather conditions of the vegetation period, the tempo of plant development and other parameters.

The first stage, which is carried out before the beginning of the irrigation season, is directed to the obtaining information on the total requirements for irrigation water during the irrigation season, as well as on its separate periods, for ordering it in water economy institutions. Mostly, calculations are made for a moderately dry year (75\% of supply) for a particular crop, and then the results are united for the crop rotation on the whole. In the modern conditions, these calculations need to be linked with the cost of electricity during the day and should be corrected to maximize the reduction in expenditures per the hectare of irrigation. Under conduction of the work concerning irrigation regime planning, it is necessary to determine the type of irrigation regime, which is meeting most closely the irrigation management strategy or the meliorative conditions of the irrigated array.

An aggregate index of irrigation regime is the irrigation norm or the total amount of irrigation water that has to be applied to the fields to overcome soil moisture deficit and to create optimal conditions for the water supply of plants. Planning irrigation regimes, it is possible to use the materials of Table 2, which contains the project parameters of irrigation norms of crops by the water-saving type of irrigation regime for the moderately dry years.

Irrigation norm consists of the norms of different types of watering (water-supplying, pre-sowing, seedling-provoking, vegetative, refreshing, 
etc.), but the most common ones are water-supplying, pre-sowing, postsowing and vegetative.

Water-supplying watering is conducted to create soil moisture reserve in the autumn period and reduce the need for vegetative watering in the spring and summer.

Pre-sowing (pre-planting) watering has a much larger range of application, they are carried out under winter crops, post-mowing and postharvest crops, under the potato of summer planting, at planting of seedlings of vegetable crops, etc. The main purpose of these watering is to obtain on time germination (seedlings striking roots) and the normal development of plants at the beginning of vegetation. In this connection, irrigation norms of pre-sowing watering are small, mostly $200-300 \mathrm{~m}^{3} /$ ha and can be applied in the areas with different groundwater level. At deep groundwater level their norm can be increased up to $500 \mathrm{~m}^{3} / \mathrm{ha}$.

Table 2

Project irrigation norms under the water-saving irrigation regimes for the areas with different groundwater levels in the moderately dry years

\begin{tabular}{|c|c|c|c|c|}
\hline \multirow{2}{*}{ Crop } & \multirow{2}{*}{$\begin{array}{c}\text { Group of } \\
\text { ripeness }\end{array}$} & $\mathbf{1 . 0 - 1 . 5}$ & $\mathbf{2 . 0 - 2 . 5}$ & $\begin{array}{c}\text { Geeper } \\
\text { than 3.0 }\end{array}$ \\
\cline { 3 - 5 } & all & $95-100$ & $120-145$ & $160-180$ \\
\hline Winter wheat & all & $75-85$ & $90-105$ & $110-130$ \\
\hline Winter barley & all & $50-60$ & $65-80$ & $80-100$ \\
\hline Spring barley & $\begin{array}{c}\text { Middle-early and } \\
\text { middle }\end{array}$ & $80-90$ & $120-135$ & $160-180$ \\
\cline { 3 - 5 } Corn for grain & middle-late & $95-110$ & $145-165$ & $190-220$ \\
\hline \multirow{2}{*}{$\begin{array}{c}\text { Alfalfa under the cover of } \\
\text { corn for green forage }\end{array}$} & all & $90-105$ & $145-175$ & $220-270$ \\
\hline \multirow{2}{*}{$\begin{array}{c}\text { Alfalfa of the past years: } \\
\text { second }\end{array}$} & all & - & $170-190$ & $280-310$ \\
\hline third & all & - & $130-150$ & $220-250$ \\
\hline Corn for silage & middle-late & $95-110$ & $145-165$ & $190-220$ \\
\hline \multirow{2}{*}{ Soybean } & early & $90-95$ & $120-130$ & $160-190$ \\
\cline { 2 - 5 } & middle & $100-110$ & $135-145$ & $200-220$ \\
\hline Sugar-beet and mangel & all & $110-125$ & $170-195$ & $240-280$ \\
\hline \multirow{2}{*}{ Potato } & early & $90-95$ & $120-130$ & $150-160$ \\
\cline { 2 - 5 } & middle & $100-110$ & $135-145$ & $170-180$ \\
\cline { 2 - 5 } & late & $120-130$ & $160-175$ & $200-220$ \\
\hline Tomato & middle & $125-145$ & $175-200$ & $220-225$ \\
\hline
\end{tabular}

Post-sowing (seedling-provoking) and after-planting watering is used to improve the striking of roots by the seedlings of vegetable crops, the potato of summer planting, on post-mowing and post-harvest crops, which are sown in dry soil. In some cases, such watering is carried out on winter crops, 
especially at late sowing periods, as well as on the crops of vegetable and late spring crops, where there is rapid drying of the sowing layer of soil and it is not possible to obtain qualitative seedlings. Post-sowing and postplanting watering humidify the soil to the depth of 15-20 centimeters with small norms (200-250 m3/ha) that makes it possible to avoid the formation of a dense soil crust, especially on heavy alkaline soils.

Vegetative watering for most crops play a major role in the formation of high yields, as well as obtaining additional products from irrigation, as they are carried out, because they are mainly conducted in the summer months during the maximum requirements of plants in easily accessible moisture. Under the planning of terms of vegetative watering, it is necessary to take into account the reaction of plants to the conditions of moisture during the vegetation. Crops have a periods of the vegetation when they are tolerant to the lack of moisture in the formation of crops and those, in which the worsening of the water regime of the soil has a negative effect on the productivity of plants. Such periods of vegetation are called critical periods and during them it is necessary to withstand intensive water supply of plants at the expense of irrigation (Table 3 ).

Intensive water supply of plants is achieved under the conditions of vegetative watering at the optimum humidity of the calculated soil layer. This index is largely determined by the physical properties of different soils and averages to: on light clays $80-85 \%$, on heavy loam $75-80 \%$, on medium loam $65-70 \%$, on light loam $60-65 \%$ of WC and on sandy loam $50-60 \%$ of the water-holding capacity (WC).

At the application of water-saving irrigation regimes in the interphase periods, which come sooner or later than the critical period, it is recommended to appoint watering at the moisture level by $5-10 \% \mathrm{WC}$ below the optimum for this type of soil. Such a decrease in pre-irrigation soil moisture, in most years (excepting the extremely dry ones), does not affect crop yields.

Perenial studies determined that the optimal pre-irrigation soil moisture is defined by the weather conditions of the vegetative period. In the years with cool weather, considerable number of days with rainfall and high humidity, vegetative watering, even during critical periods, can be appointed at the humidity by $5-10 \%$ lower than the optimum for this type of soil. In dry years, on the contrary, irrigation should be carried out at soil humidity by 5 $10 \%$ of WC higher than the optimum indexes and, first of all, during critical periods. 
Critical in water supply periods of plants development (by the materials of the Department of Irrigated Agriculture of the Institute of Irrigated Agriculture of NAAS)

\begin{tabular}{|c|c|}
\hline Crop & Critical period \\
\hline Winter and spring cereals & Stem elongation - grain formation \\
\hline Corn for grain & Before 10 days to taseling - 20 days after flowering \\
\hline Millet, sorghum, soriz & Panicle ejection - grain formation \\
\hline Soybean & Budding, flowering - grain formation \\
\hline Sunflower & Calathium formation - grain formation \\
\hline Sugar-beets & The period of intensive growth of leaves and root-crops \\
\hline Cornb for silage & 9-10 leaves - grain formation \\
\hline Alfalfa of the past years & Spring and after-mowing regrowth - budding \\
\hline Potato & Budding - beginning of leaves yellowing \\
\hline Tomato & Fruit inception and growth \\
\hline Cabbage & Formation of decumbent crown, ripening of heads \\
\hline Cucumber & Fruitage \\
\hline
\end{tabular}

At the determination of the terms and norms of vegetation watering, which are carried out by sprinkling or surface method, an important parameter is the depth of soil humidification (the estimated layer). Scientific studies show that the depth of soil humidification must be differentiated depending on the physical properties of the soil, the level of groundwater, the stages of plant development, the strength of their root systems, and so on. At a deep level of groundwater on the crops of perennial herbs, mangel and sugar-beets, cereals, corn, soybean and other crops with a well-developed root system, the estimated layer is, mostly, 0.5-0.7 m, and on annual herbs, potatoe, onions $-0.3-0.5 \mathrm{~m}$.

The irrigation norms of watering must meet the following conditions: provide humidification of the soil layer in which the main mass of the root system of plants is located, exclude gravitational losses of water outside the zone of active moisture exchange, and allow it to accumulate atmospheric precipitation, etc.

Under the water-saving regimes, special attention is paid to the terms of vegetative watering for individual crops, taking into account their biological features.

On the winter wheat, this question has been studied for a number of years at the deep groundwater level at the Ingulets irrigation system (Table 4).

The scheme of the experiment provided for the next terms of irrigation termination: 1 . autumn water-supplying; 2 . carrying out spring vegetative watering until the earing stage; 3 . carrying out spring vegetative watering 
until the stage of grain formation; 4. carrying out spring vegetative watering until the stage of milk ripeness of grain.

Table 4

Influence of the terms of vegetative watering termination on the irrigation water consumption and winter wheat productivity

\begin{tabular}{|c|c|c|c|c|c|}
\hline № & $\begin{array}{l}\text { Term of the } \\
\text { watering } \\
\text { termination }\end{array}$ & $\begin{array}{l}\text { Number of } \\
\text { watering }\end{array}$ & $\begin{array}{c}\text { Irrigation } \\
\text { norm, } \mathbf{m}^{3} / \mathbf{h a}\end{array}$ & $\begin{array}{c}\text { Grain } \\
\text { yield, t/ha }\end{array}$ & $\begin{array}{c}\text { Coefficient of } \\
\text { irrigation } \\
\text { efficiency, } \mathbf{m}^{3 / t}\end{array}$ \\
\hline 1 & No irrigation & - & - & 2.14 & - \\
\hline 2 & $\begin{array}{l}\text { Watering until } \\
\text { the earing }\end{array}$ & 1.7 & 750 & 5.84 & 1071 \\
\hline 3 & $\begin{array}{l}\text { Watering until } \\
\text { the grain } \\
\text { formation }\end{array}$ & 2 & 1000 & 6.36 & 820 \\
\hline 4 & $\begin{array}{c}\text { Watering until } \\
\text { the milk ripeness } \\
\text { of grain }\end{array}$ & 3 & 1500 & 6.80 & 904 \\
\hline \multicolumn{4}{|c|}{$\mathrm{LSD}_{05}, \mathrm{t} / \mathrm{ha}$} & 0.27 & \\
\hline
\end{tabular}

During the whole vegetation, watering was appointed by the moisture content of 0.5 meters layer of soil at $70 \%$ of the water-holding capacity. The years of the experiments conduction by temperature and rainfall were favorable for winter wheat cultivation, as it is testified by the indexes of the crop yield. For the years of the study it was found that the highest yield of the crop on the background of water-supplying watering was obtained under the conduction of it in the inter-stage period of spring regrowth - earing. Watering in the next stages significantly increases the productivity of plants, but the coefficient of irrigation efficiency is reduced. Certainly, this fact should be taken into account at planning the irrigation regime of the crop.

On drip irrigation systems, watering norms should take into account the area of humidification and the frequency of irrigation (daily, 2-3 days, a week, etc.). It is known that, depending on the physical properties of different soils, optimal conditions for the development of plants are created at the moisture content of $85-90 \%$ of the water-holding capacity in the estimated layer on heavy-loamy and middle-loamy soils. On light loamy and sandy soils such conditions are formed at the humidity of 70-80\% of WC. In this regard, in the case of drip irrigation, at these soil moisture indexes it is advisable to plan the start of vegetation watering or renew them after heavy rains, which moisten the estimated soil layer to the water-holding capacity. At the early stages of crops development, when average daily evaporation is insignificant, irrigation is usually carried out one time per week. During the critical periods of water consumption, at high temperatures and low 
humidity of air, when the average daily evaporation increases to 60-70 $\mathrm{m} 3 / \mathrm{ha}$ and the decreased water supply of plants leads to a significant crop losses, irrigation in the weather without rains should be carried out daily.

Of course, planning irrigation regimes is a painstaking work that requires time and certain knowledge. However, in the end, it has to provide the answer to the question - how much water should be ordered by the decades and for the irrigation season on the whole.

\section{Comparative characteristics of the ways and methods of the appointment of watering of the major crops}

The bioclimatic method of S.M. Alpatyev and the biophysical method of D.A. Shtoyko are the most widely spread in Ukraine. These methods worked out the regimes of irrigation under the design of construction and reconstruction of irrigation systems, drawing up plans for water use of farms, creating information and advisory systems for irrigation planning, etc.

To check the calculations of water consumption by crops by the average daily evaporation, as well as to establish with accordance to methodological recommendations by using the biophysical method of the Institute of Irrigated Agriculture and the bioclimatic method of the Institute of Water Problems and Land Reclamation of the National Academy of Agrarian Sciences of Ukraine, their comparative evaluation has been performed. By the perennial data of field experiments of the Institute of Irrigated Agriculture with many field crops beginning from the 60-ies years of the past century, actual parameters of irrigation regime at the optimum level of water supply of plants were determined.

Thus, according to the working hypothesis of the studies, a comparative evaluation of conventional and new estimation methods was carried out at the determination of the irrigation norm of alfalfa of the 2 nd year of use in separate years. The actual indexes of irrigation norms in the experiments of the Institute of Irrigated Agriculture under the regime of alfalfa irrigation in the variant with the appointment of vegetative watering according to the optimal indexes (75-80\% of WC) of soil moisture during the entire irrigation season were taken as a standard.

The calculations took into account the parameters of the beginning of spring regrowth of the plants and the date of the last watering of alfalfa in a particular year. At the spring regrowth of plants, a deficit of moisture in the estimated soil layer $(0.7 \mathrm{~m})$ was determined each year. The calculations were performed according to the well-known methodological guidelines for determination of the water consumption by alfalfa plants. 
In this, the calculated terms of vegetation watering were not taken into account - only the actual and calculated irrigation norms were compared. Rainfall, average daily temperature, relative humidity and humidity deficiency of air were determined by the materials of Kherson Agrometeorological Station, near which during all the years the field experiments with alfalfa were carried out (Table 5).

Table 5

\section{Comparative assessment of thevalues of irrigation norms of alfalfa in} the second year of its life, calculated by different methods

\begin{tabular}{|c|c|c|c|c|c|c|c|c|c|c|c|}
\hline \multirow{3}{*}{ № } & \multirow{3}{*}{ Year } & \multirow{3}{*}{ 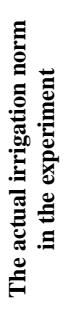 } & \multicolumn{3}{|c|}{$\begin{array}{l}\text { According to the } \\
\text { average daily } \\
\text { evaporation }\end{array}$} & \multicolumn{3}{|c|}{$\begin{array}{l}\text { Biophysical of the } \\
\text { Institute of Irrigated } \\
\text { Agriculture }\end{array}$} & \multicolumn{3}{|c|}{$\begin{array}{l}\text { Bioclimatic of the } \\
\text { Institute of Water } \\
\text { Problems and Land } \\
\text { Reclamation }\end{array}$} \\
\hline & & & \multirow{2}{*}{ हू } & \multicolumn{2}{|c|}{$\begin{array}{c}\text { deviation } \\
\text { from the } \\
\text { actual } \\
\text { irrigation } \\
\text { norm } \\
\end{array}$} & \multirow{2}{*}{ 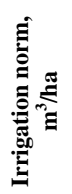 } & \multicolumn{2}{|c|}{$\begin{array}{c}\text { deviation } \\
\text { from the } \\
\text { actual } \\
\text { irrigation } \\
\text { norm }\end{array}$} & \multirow{2}{*}{ 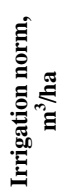 } & \multicolumn{2}{|c|}{$\begin{array}{c}\text { deviation from } \\
\text { the actual } \\
\text { irrigation } \\
\text { norm }\end{array}$} \\
\hline & & & & $\mathbf{m}^{3} / \mathbf{h a}$ & $\%$ & & $\mathrm{~m}^{3} / \mathbf{h a}$ & $\%$ & & $\mathrm{~m}^{3} / \mathbf{h a}$ & $\%$ \\
\hline \multicolumn{12}{|c|}{ Humid and moderately humid years } \\
\hline 1 & 1982 & 3550 & 3654 & +104 & 3 & 2889 & -661 & 19 & 2381 & $\begin{array}{c}- \\
1169\end{array}$ & 33 \\
\hline 2 & 1985 & 3300 & 3421 & +121 & 4 & 2596 & -704 & 21 & 2537 & -763 & 23 \\
\hline 3 & 1987 & 4900 & 4595 & -305 & 6 & 4137 & -763 & 16 & 3847 & $\begin{array}{c}- \\
1053\end{array}$ & 21 \\
\hline 4 & 1988 & 3150 & 3986 & +836 & 27 & 3563 & +413 & 13 & 3215 & +65 & 2 \\
\hline \multicolumn{2}{|c|}{$\begin{array}{l}\Sigma \text { for } 4 \\
\text { years }\end{array}$} & 3725 & 3914 & +189 & 5 & 3296 & -429 & 12 & 2995 & -730 & 20 \\
\hline \multicolumn{12}{|c|}{ Moderate years } \\
\hline 5 & 1969 & 5460 & 4422 & -1038 & 19 & 4293 & -1187 & 21 & 3831 & -1629 & 30 \\
\hline 6 & 1970 & 4952 & 4707 & -245 & 5 & 4415 & -537 & 11 & 3719 & -1233 & 25 \\
\hline 7 & 1983 & 4350 & 3896 & -454 & 10 & 3338 & -1012 & 23 & 2866 & -1484 & 33 \\
\hline 8 & 1984 & 4850 & 5365 & +515 & 11 & 5446 & +596 & 12 & 4454 & -396 & 8 \\
\hline \multicolumn{2}{|c|}{$\begin{array}{c}\Sigma \text { for } 4 \\
\text { years }\end{array}$} & 4903 & 4598 & -305 & 6 & 4373 & -530 & 11 & 3718 & -1185 & 24 \\
\hline \multicolumn{12}{|c|}{ Moderately dry and dry years } \\
\hline 9 & 1971 & 4959 & 4889 & -70 & 1 & 5612 & +663 & 13 & 4333 & -626 & 13 \\
\hline 10 & 1972 & 4842 & 5019 & +117 & 4 & 6787 & +1945 & 40 & 5368 & +526 & 11 \\
\hline 11 & 1986 & 4350 & 4729 & +379 & 9 & 5485 & +1135 & 26 & 4527 & +177 & 4 \\
\hline 12 & 1992 & 5100 & 5293 & +193 & 4 & 6064 & +964 & 19 & 4864 & -236 & 5 \\
\hline \multicolumn{2}{|c|}{$\begin{array}{c}\text { Average } \\
\text { for } 4 \text { years }\end{array}$} & 4813 & 4982 & +169 & 4 & 5987 & +1174 & 24 & 4773 & -40 & 1 \\
\hline \multicolumn{2}{|c|}{$\begin{array}{l}\text { Average } \\
\text { for } 12 \\
\text { years }\end{array}$} & 4480 & 4498 & +18 & 5 & 4552 & +72 & 2 & 3829 & -651 & 15 \\
\hline
\end{tabular}

*Note: The materials are generalized by the author with accordance to the reports, data of meteorological station. 
The analysis of the Table testifies that at the comparative evaluation of the estimation methods between themselves and with the instrumental method by soil moisture the average long-term data must not be used, as most researchers do, but we have to perform a comparison with the standard (in our case - with the actual irrigation norm) data of individual years. This approach allows obtaining reliable data on the evaluation of the efficiency of the application of one or another estimation method.

At the planning of the irrigation regime of any crop, we need to have data on moisture consumption in the average dry years (75\% of supply), and at the managing during the vegetation - to use the materials that simulate the weather conditions. Therefore, we provide comparative data on the efficiency of the estimation methods in the years of different provision with natural factors.

According to the performed studies, for an average of 12 years, all the estimation methods provided high accuracy in the determination of the irrigation norm, compared with the actual data in the field experiments. However, this is the result of smoothing the data by imposing differences with different signs $(+,-)$ over the years.

Other results were obtained at the grouping of the years with the same supply: in humid and moderately humid years, deviations in irrigation norms in the application of conventional estimation methods reached $12-20 \%$, in moderate years $-11-24 \%$, and in moderately dry and dry $-1-24 \%$.

The studies on the regime of irrigation of alfalfa in recent years show that under the optimal water supply, it provides the maximum yield. However, the reduction of irrigation norm by $10-15 \%$, nearly does not affect the yield level, especially in humid and moderate years.

For the 12 years of observations, conventional computational methods significantly cede to the new method, in which the irrigation norm error of $15 \%$ was observed twice (17\%). At the application of the bioclimatic method, this error ocurred 8 times (67\%) and at the biophysical one 6 times $(50 \%)$.

In the world practice of the determination of the moisture content of certain territories by estimation methods, the obtained figures are considered quite reliable if they have deviations from the balance-drier method indexes within $10-15 \%$ in any direction. Using this substantiation, we can conclude that fluctuations in the irrigation norm of $10-15 \%$ have virtually no effect on crop yields, which allowed us to take this indicator into account under the analysis of the obtained materials. At the same time, we consider it necessary to note that the increase of irrigation norm under the use of the estimation methods by $450-550 \mathrm{~m} 3 / \mathrm{ha}$ (on average by 1 watering) leads to 
an increase in the costs of agro- and energy resources for watering the crop with almost no increase in yield. On the contrary, reducing the irrigation norm by such a value, especially during the critical periods of plant development, can lead to a significant decrease in productivity. The analysis of the reliability of the calculated irrigation norms, compared with the actual in the experiments, gives the following results. For 18 years of the observations, well-known estimation methods within $15 \%$ of deviations provide: the biophysical method -11 years $(61 \%)$ and the bioclimatic one 12 years $(67 \%)$ of reliable results. The daily evaporation method provided 14 years $(78 \%)$ of the calculations within $\pm 15 \%$ of the deviations from the actual irrigation norms at the experimental plots. The proposed estimation method works quite clearly with sufficient accuracy in different meteorological conditions, especially in humid and moderate years.

Thus, the method we have developed to determine the moisture consumption of basic crops by the average daily evaporation provides a sufficiently high percentage of reliability of results and can be used to form the regime of irrigation of basic crops.

\section{CONCLUSIONS}

1. In the conditions of Southern Steppe, the use of water-saving regimes is most positively affected by cereals, soybean, alfalfa and potato, which under the reduction of the irrigation norm by $19.1-41.8 \%$, almost do not lose their yield.

2. The new method of the determination of the regime of irrigation of main crops with accordance to the indexes of daily evaporation is based on the requirements of plants to the water regime of soil taking into account the weather conditions of vegetation, meliorative conditions of the field, etc.

3. Comparative evaluation of the new estimation method with the most common in Ukraine for the determination of watering and irrigation norms in different weather conditions testifies about sufficiently high accuracy, and the results are close to those obtained directly in the field.

\section{SUMMARY}

The article presents the results of a study on the effects of irrigation regime types on crops productivity. Besides, a comparative evaluation of the new method of the vegetative watering assignment with others, most common in Ukraine, is provided.

It was determined that under the current conditions of economic management it is practically impossible to find an alternative to the watersaving model of the irrigation regime for crops. In the conditions of 
Southern Steppe, cereals, soybean, alfalfa and potato, which under the irrigation rate reduction by $19.1-41.8 \%$ almost do not lose their yields, reacted positively on the introduction of water-saving irrigation regimes.

Comparative evaluation of the new calculation method with the most common in Ukraine for the determination of irrigation and watering norms in different weather conditions testifies about a sufficiently high accuracy, and the obtained results are close to those got directly in the field where the balance-drier method was the standard.

\section{REFERENCES}

1. Авдеев Ю. И. Рекомендации по возделыванию сельскохозяйственных культур при капельном орошении. М.: Изд. МСХ РФ, 2003. $46 \mathrm{c}$.

2. Балюк С. А., Ромащенко М. І. Наукові аспекти сталого розвитку зрошення земель в Україні. К. : ДІА, 2006. 32 с.

3. Писаренко П. В., Вожегова Р. А., Лавриненко Ю. О., Коковіхін С. В. Вимоги сільськогосподарських культур до режиму зрошення. Посібник украӥнського хлібороба. 2011. С. 95-100.

4. Жовтоног О. І., Філіпенко Л. А., Шостак І. К., Поліщук В. В. Сучасна концепція та методи управління зрошенням на рівні господарства в умовах недостатнього зволоження. Наукові основи землеробства в умовах недостатнього зволоження. К., 2001. С. 89-92.

5. Жуйков Г. Є. Економічні засади ведення землеробства на зрошуваних землях. Херсон : Айлант, 2003. 288 с.

6. Кириенко Т. Н., Остапчик В. П., Жовтоног О. И. Основные принципы разработки почвозащитных режимов орошения. Oрошаемые черноземы и их рациональное использование. Новочеркасск: НПО «Мелиорация», 1990. С. 85-92.

7. Латифов Н. Л., Кобозев И. В., Парахин Н. В. Оптимизация режимов орошения сельскохозяйственных культур. М. : МСХА, 1996. $94 \mathrm{c}$.

8. Льгов Г. К., Адиньяев Э. Д. Водопотребление и режим орошения кукурузы. Агробиологическое обоснование поливного режима и применение удобрений под кукурузу. Тр. Горского СХИ. 1974. С. 3-37.

9. Методические указания по применению биофизического метода для определения эффективных запасов влаги в почве м сроков полмва сельскохозяйственных культур. Херсон: 1975. 77 с.

10. Писаренко В. А., Коковіхін С. В., Іванов І. Т., Тищенко О. П., Мішукова Л. С. та ін. Методичні рекомендації по застосуванню 
водозберігаючих режимів зрошення сільськогосподарських культур. Херсон : Айлант, 2002. 32 с.

11.Писаренко В. А. Методичні підходи до формування водозберігаючих режимів зрошення культур у степовому регіоні. Наукові основи землеробства в умовах недостатнього зволоження: Матер. наук.-практ. конф. 21-23 лютого 2000 р. К.: Аграрна наука, 2001. C. 181-189.

12. Писаренко В. А. Особливості планування режимів зрошення сільськогосподарських культур в умовах дефіциту водно-енергетичних ресурсів. Актуальні проблеми ефективного використання зрошуваних земель. Сб. наук. праць ін-т. зрошув. землер. Херсон, 1999. № 2. С. 8-12.

13. Розгон В. А. Оптимізація водного балансу зрошуваних територій. Зрошуване землеробство. 2002. № 3. С. 87.

14. Ромащенко М. І., Балюк С. А. Зрошення земель в Україні. Стан та шляхи поліпшення. К. : Світ, 2000. 114 с.

15. Ромащенко М. І., Жовтоног О. І., Філіпенко Л. А., Деменкова Т. Ф. Методика планування оптимальних екологічно безпечних режимів зрошення. К. : УкрНИИГиМ, 1997. С. 43.

16. Справочная книга по орошаемому земледелию. Общая ред.: Погребняк А.П., Калашников К.Г. Кишинев: Картя Молдовеняскэ. 1990. $134 \mathrm{c}$.

\section{Information about the author:} Pysarenko P. V., Doctor of Agricultural Science, Senior Researcher, Chief Researcher, Institute of Irrigated Agriculture of the National Academy of Agrarian Sciences of Ukraine Kherson, Naddniprianske, 73483, Ukraine 
DOI https://doi.org/10.36059/978-966-397-154-4/185-200

\section{PECULIARITIES OF THE IMPLEMENTATION OF THE BASIN PRINCIPLE IN THE MANAGEMENT OF WATER RESOURCES IN UKRAINE}

\section{Stashuk V. A.}

\section{INTRODUCTION}

The water resources of Ukraine are the part of natural water reserves that are directly involved or may be involved in social production under specific historical conditions with a certain development of productive forces. This definition characterizes water resources not only as a natural phenomenon, but also as a socioeconomic category that is directly connected with the level of the development of society. Owing to the specific features, which differentiate them from other natural resources (high dynamism and interconnections, which is explained by the objective processes of water circulation in nature), water resources could be used many times and for different purposes that requires optimization of water use.

The water resources of our planet are about 1.5 billion cubic $\mathrm{km}$. However, $98 \%$ of them are saline waters of the World Ocean, and only 28 million cubic $\mathrm{km}$ are fresh-waters. But owing to the technological possibilities for desalination of saline sea-waters, the waters of the oceans and saline lakes could be considered as potential water resources, the use of which is quite possible in the future.

The river runoff resources of Ukraine average to 87 billion cubic $\mathrm{m}$ per year (in low water year this index decreases to 56 billion cubic $\mathrm{m}$ ). The river network of Ukraine is more than 71,000 rivers with the total length of more than 170 thousand $\mathrm{km}$. Its average density is $0.25 \mathrm{~km} / \mathrm{km} 2$. Almost all rivers belong to the basins of the Black and Azov seas and only $4 \%$ belong to the Baltic Sea. Water resources of Ukraine are formed mainly owing to the runoff of the Dnipro, Dnister, Siverskyi Donets, Pivdennyi Buh, Tysa rivers, on which the reservoirs are built. Specific supply of the river runoff in Ukraine - about 1 thousand cubic $\mathrm{m}$ per person per year that is 2.5 times 
lower than in Germany and Sweden, 3.5 times than in France and 5 times than in England ${ }^{1}$.

Ukraine belongs to the least supplied with own water resources country of Europe. Most natural water sources are scarce, and water resources of Ukraine become a limiting factor in the development and allocation of productive forces. Water use volumes in the river basins have almost reached the upper limit, and there is a conflict between the demand for water and the capacity to meet it both in quantity and quality (especially for drinking purposes). Because of excessive anthropogenic load, disturbance of the conditions of the river runoff formation and natural balance, which led to a decrease in the quality of water resources, the threatening ecological condition has developed in almost all river basins of Ukraine, and especially in the Dnipro basin - the main source of water supply in the country. More than $70 \%$ of the state's water supply is provided by the surface runoff of the Dnipro basin ${ }^{2}$. Therefore, the question of rational use of water resources, their reproduction and protection is the main task of the state policy of Ukraine today.

\section{Assessment of anthropogenic load on the river basins of Ukraine}

The water economy system is a hydraulically and organizationally interconnected set of sources of water resources, water users, water management tools for their rational use, reproduction, storage and protection against pollution. Water economy system (WES) consists of a great number of elements aimed to satisfy economic, socioenvironmental, aesthetic and other needs of society in water of the required quantity and quality. Besides meeting the needs of production and society for water in the appropriate volume, regime and quality, it is also intended to maintain ecological balance in the basin and protect the environment from the harmful effects of water. The water economy system can be classified as a large (complex) system because it contains water resources as a basis, consists of many artificial engineering constructions and has branchy links with the natural, social and economic environment.

To provide consumers with water in the appropriate volumes and quality, different water economy constructions are used depending on the purpose of the water. The main constructions of water supply are water intakes, pump

\footnotetext{
1 Постанова Верховної Ради України «Про Концепцію розвитку водного господарства України». Прийняття від 14.01.2000. Режим доступу: https://zakon.rada.gov.ua/laws/show/1390-14

2 Данилишин Б. М., Дорогунцов С. І., Міщенко В. С., Коваль Я. В., Новоторов О. С., Паламарчук М. М. Природно-ресурсний потенціал сталого розвитку України. К.: РВПС України, 1999. 716 с.
} 
stations, regulating constructions, canals and water diversion systems, water purification stations and water distribution systems. Various protective constructions (flood dams, antislip structures, water drainage constructions, etc.) are used to prevent the harmful effects of water and to prevent accidents and catastrophes.

A distinctive feature of water economy systems is their inter-sector character. Water in Ukraine is used by about 30 thousand types of water users, among which are objects of national, regional and territorial and local importance, which extremely complicates the efficient management of them. Water resources management begins with planning of the regimes of the water economy system, which is based on the analysis of water economy balances. Therefore, water resources management is a complex technological process, which is carried out by organizing appropriate measures in such a way that the optimal use of available resources (water, energy, human) is provided to achieve the intended purpose - provision of all consumers with calculated reliability of water with the required volumes and quality.

The water economy complex of the Dnipro basin has been developed for several decades in the direction of increasing water use and runoff regulation without taking into account economic and environmental consequences for Ukraine. The largest number of industrial enterprises, the largest energy facilities and arrays of irrigated lands are concentrated in the Dnipro basin. Despite the fact that water uptake from the Dnipro River and the rivers of its basin has recently considerably decreased, the quality of the Dnipro water has not improved due to the loss of restorative capacity and the decrease in the efficiency of purification constructions. The Dnipro provides water to consumers not only within its basin, but is also the main source of water supply for industrial centers of the South and Southeast of Ukraine. The Dnipro-Donbas, the North Crimean, the Kakhovka canals annually transfer 5-6 billion $\mathrm{m}^{3}$ of water outside the basin. Water supply to Donbas, Kharkiv, Kryvbas, Crimea is solved by supplying the Dnipro water.

The ecological situation in the Dnipro basin is related to the processes of soil erosion due to the high level of plowed land (up to 70\% of the basin area) and low forest cover (twice less than optimal). Soil erosion products are carried away by the surface runoff and pollute rivers and reservoirs. Contamination of water, as well as water intake landscapes, with chemical compounds, has led to changes in the natural balance of many rivers of the basin, complicating the problem of obtaining qualitative drinking water due to the imperfect water purification technologies under the conditions of increasing anthropogenic and radiation loads on the environment. Much of 
the Dnipro basin and cascade reservoirs are contaminated with radionuclides. Surface and groundwater, soils of the Dnipro basin are very polluted. The level of this pollution has reached the levels at which it is impossible to clean them with the available technologies and purification facilities.

The water economy complex of Ukraine has developed over many decades without taking into account environmental requirements and environmental consequences. The self-healing capacity of the water resources of Ukraine is already insufficient to overcome the negative impacts and recover the disturbed ecological balance. Particularly unsettling is the fact that in recent years not only levels of pollution of wastewater effluents have increased, but also volumes of wastewater that are not treated at all. In the last decade, due to the aging and excessive wear of water purification constructions, their considerable energy intensity and technological backwardness and reduced efficiency, the environmental risk of mass technological and environmental accidents and catastrophes in water bodies has increased. The extreme technogenic load on the water resources of the country resulted in that all surface and connected with them groundwater are contaminated with a significant exceed of the maximum permissible concentration (MPC).

An increase in the discharge of contaminated wastewater without purification is observed in the Dnipro basin (by 72.3\%), the Crimean rivers (by 50\%) and the Southern Buh basin (by 21\%). The discharge of such waters in the Siverskyi Donets basin (by 22\%) and the Danube (by 30\%) has slightly decreased. According to the Institute of Geography of the National Academy of Sciences of Ukraine, the water quality according to the integrated ecological index (at an index of more than 12 it is water of «poor» quality) for the territory of Ukraine is characterized by the following: the most polluted water is in the Donbas, the Steppe zone of the Dnipro, in the Azov region (Donetsk index - 45.3, Dnipropetrovsk - 16.7, Zaporizhzhia 12.4; Mariupol - 31.0) $)^{3}$.

Considerable attention to solving the problems of drinking water supply and improving the ecological conditions of water sources is paid in the Law of Ukraine «National Target Program for the Development of Water Economy and Environmental Healing of the Dnipro River by $2021 »{ }^{4}$. Based on the analysis of ecological conditions and hydro-chemical composition of

\footnotetext{
${ }^{3}$ Дезірон О. В. Водокористування в Україні: сучасний стан та перспективи розвитку. Водне господарство України. К.: 2003, № 3-4. С. 4-8.

4 Закон України «Загальнодержавна цільова програма розвитку водного господарства та екологічного оздоровлення р. Дніпро до 2021 року». Прийняття від 24.05.2012. Режим доступу: https://zakon.rada.gov.ua/laws/show/4836-17
} 
water of the basins of the main rivers of Ukraine, we can draw the following conclusions:

1. The technogenic load on aquatic ecosystems has reached a critical limit due to the extensive way of management, which has led to a significant reduction in ecological and sanitation costs and the depletion of water resources.

2. There is a tendency for permanent pollution of surface waters due to the discharge of unpurified or insufficiently purified waste-waters into reservoirs, diversion of effluents from settlements and agricultural lands, unsatisfactory technical condition and level of exploitation of water economy systems and purification facilities.

3. The deterioration of surface waters quality, and especially of drinking water, because of the poor ecological conditions of water sources in the basins, the use of imperfect outdated water treatment technologies in existing water supply systems.

4. The main pollutants of the water of the Dnipro basin are biogenic elements (organic and nitrogen compounds, iron) and there is a gradual increase in water mineralization, content of ammonium nitrogen, nitrates, phosphates, heavy metals that testifies about an increase of anthropogenic load on the water objects, ineffective functioning of the purification constructions of cities and industrial enterprises and an increase in discharges of unpurified or insufficiently purified waste-waters.

5. The crisis of water economy and ecological situation in the basin of the main rivers of Ukraine is caused by the nature of farming and the discharge into the water bodies of a considerable amount of polluted waters of industry, agriculture and communal services. Particularly harmful are surfactants, pesticides, biogenic substances, heavy metals, petroleum products, phenols.

6. The great effect on the environmental conditions of rivers, including the volume of floods, has a negative change in the water intake areas of small rivers due to the soil erosion and low forest cover (deforestation).

7. The lack of an efficient economic mechanism of water management and implementation of environmental measures, the imperfection of the existing system of management of protection and use of water resources due to the lack of a legal framework have a negative effect on the solution of ecological water problems.

Thus, at the present level of anthropogenic load, almost most rivers of Ukraine have lost their ability to self-purification, and the condition of rivers, especially small ones, is approaching the limit of pollution, which can lead to dramatic disturbance of natural ecosystems. 


\section{Improvement of the state policy in water resources and water economy management}

Determination and scientific substantiation of strategic goals and directions of the increase of ecological sustainability and balanced development of water economy, provision of the population with qualitative drinking water, minimization of losses and social tension due to the harmful effect of water, conservation of aquatic ecosystems - this is not a complete list of priority tasks, solving of which is envisaged by the state programs.

The realization of the envisaged measures is based on a comprehensive assessment of the level of natural provision with water resources, peculiarities of their territorial distribution, which does not correspond to the location of water-intensive branches of the economic complex. Although gross domestic product has declined considerably in recent years, there is a tendency for an increase in the discharge of contaminated wastewater, $88 \%$ of which is attributed to the ferrous metallurgy, coal and chemical industries. The volume of pollution of municipal wastewater has increased 1.4 times $^{5}$. At the same time, the indexes are increasing every year, which indicates that with a significant reduction in production, the environmental situation in Ukraine is not improving, and the resource and water consumption of the products is increasing.

The crisis of water resources, apart from technogenic load, is caused by the fact that Ukraine is one of the least water-supplied countries in Europe. According to UNESCO, Ukraine ranks 95th among 122 countries in terms of rational use of water resources and water quality, including the availability of purification facilities.

The cause of the crisis in the water economy is primarily the extensive development of the economy of the country, which lasted for many years. In order to stabilize and improve the ecological conditions of the water sector and to develop the directions of crisis management, it is necessary to understand the reasons that has led to it. They are, first of all, the following: high resource and energy consumption of old technologies, which are 2-3 times higher than in the developed countries; high concentration of outdated industrial objects; the lack or insufficient power of purification facilities and the imperfection of purification technologies; lack of legal and economic mechanisms to stimulate the development of environmentally friendly technologies and environmental-protective systems.

\footnotetext{
5 Водний менеджмент в Україні: проблеми та інновації розвитку: [колективна монографія] /за ред. Л. Ф. Кожушко, В. А. Сташука, М. А. Хвесика, А. М. Рокочинського. Рівне, 2018. 638 с.
} 
The transition of Ukraine to sustainable development has to be preceded by the reform of economic policies and branches of the economy that have an environmental focus. The system of water economy complex and water resources management also needs to be reformed and switched into an integrated approach and basin principle, creation of institutions for collective management of water use, introduction of new economic instruments and levers through decentralization of management.

In the nearest perspective, the efficiency of the state's environmental policy should be based on the following basic principles: minimization of anthropogenic load and liquidation of its negative consequences, introduction of environmental protection, in particular water conservation, measures in the system of water use and diversion.

One of the priorities of the environmental policy of Ukraine is the harmonization of Ukrainian legislation with the EU one. For the realization of the Decree of the President of Ukraine «About the Program of Integration of Ukraine into the European Union», the Cabinet of Ministers adopted a number of measures directed at the gradual harmonization of Ukrainian legislation in the field of environment, natural and water resources and environmental safety with the EU directives ${ }^{6}$. The realization of the state policy of sustainable development of the water economy is based on the achievement of strategic goals, which include the reproduction and protection of water objects, the improvement of the technical and sanitary reliability of water economy systems, rational water use. The Law of Ukraine «On the National Program for the Development of Water Management» (dated 17.01.2002 No. 2988-III) provides for the following prospective priority measures: the realization of measures concerning the improvement of the ecological conditions of meliorative systems and bring the ecological and resource conditions of water objects to the requirements of basic standards that would guarantee the safety of life of the population and the achievement of the balance between the levels of anthropogenic influence on water objects and their recovery capacity. The achievement of these goals implies a targeted policy towards the main water users. In housing, the most important task is to take steps to achieve the efficient functioning of purification constructions. For that, it is necessary to limit the reception without local purification of industrial effluents, to build the constructions of additional purification of waste-waters, not to allow the overload in the work of purification constructions.

\footnotetext{
6 Указу Президента України «Про програму інтеграції України в Європейський Союз». Прийняття від 10.07.2015. Режим доступу: https://zakon.rada.gov.ua/laws/show/ n0001100-00.
} 
In agriculture, it is necessary to introduce a complex of agrotechnical measures and engineering technologies to reduce the income of pollutants, the water consumption of irrigated agriculture.

Realization of the planned measures requires improvement of the normative base of water use, increase of the quality of observations on the conditions of water objects (monitoring, state control in the field of water use, improvement of state water cadastre), implementation of flexible economic methods of water use regulation. Water economy problems, which have a complex character and which are impossible to be solved without state support and coordination of inter-sector communications, are solved through the development and implementation of state target programs. These include problems that are typical for the whole territory of Ukraine provision of the population with qualitative drinking water, prevention of the harmful effects of water, recovery of water quality in water objects and other regional water economy environmental problems.

Much attention should be paid to solving the problem of village water supply. The main task is to provide at least $50 \%$ of the villages with centralized water supply in combination with water diversion systems, and especially where the population uses imported water.

Due to the increasing of crisis water-ecological phenomena and the introduction of limits on energy consumption in agriculture, there is a need to improve and optimize irrigation regimes and norms. A method of saving water and reducing irrigation rates at the expense of the reduction of water losses for evaporation that is achieved by nocturnal irrigation, subsoil and drip irrigation, reduction of the total hydro module of irrigation crop rotation through the formation of rotations is prospective. The defining principles of water supply and water use in the transition to sustainable socioeconomic development of the state are:

- priority of the social sphere of water use, provision of the population with qualitative drinking water and in sufficient quantity;

- management of water economy and water protection activities by the basin principle;

- ecologically adapted, by the water factor, development of the economic potential of the regions on the basis of the assessment of the conditions of water resources and forecasting their changes;

- introduction of water-saving technologies in economic sectors;

- optimization of national and regional interests on the basis of greening of technologies of water uptake from water-resource sources;

- compliance with international law, cooperation in the field of use and protection of trans-boundary aquatic ecosystems; 
- reconstruction and maintenance of ecological safety of renewal and modernization of water economy and meliorative systems;

- formation of legal, economic and organizational principles of rational water use.

Considering that the water economy complex of Ukraine is characterized by the formed productive potential and limited capacities, the main role in the further development of water economy should belong to the processes of reconstruction, modernization of water economy systems, replacement of outdated technologies and systems of water supply and water purification with innovative technologies.

\section{Peculiarities of implementation of integrated approach and basin principle in water resources management of Ukraine}

For the last 25 years, the population of Ukraine and the production of goods and services have declined significantly, leading to a significant reduction in both water consumption (from $30 \mathrm{~km} 3$ in 1990 to $<9.7 \mathrm{~km} 3$ in 2015) and wastewater discharges by various sectors of the economy (from $18 \mathrm{~km} 3$ in the 1990 s to $5.3 \mathrm{~km} 3$ in 2015) ${ }^{7}$. However, a corresponding improvement in the quality of water resources is not observed, on the contrary, there are negative trends of increasing water scarcity due to the pollution and depletion of water resources, degradation of aquatic ecosystems and on the background of a negative effect of climate change. Problems with public access to water objects and safe drinking water are increasing. One of the key reasons of the current situation is the inefficient management system in the field of protection and recovery of water, rational use of water resources and development of water economy and land reclamation.

Despite the creation of basin administrations within the territorial structure of the State Agency for the past decade, the management is carried out at the level of administrative units: regions, districts or inter-regional or inter-district interaction of the objects of the water economy complex, without taking into account the basic natural factors of formation and interconnection of water (surface and underground) resources within the river basin - the water intake territory.

Agriculture of Ukraine directly generates 17\% of GDP, $20 \%$ of exports and more than $14 \%$ of work positions and is one of the most important points of growth of the national economy. The inefficient management of the state water economy complex and its under-funding for the purposes of tending, maintenance and re-equipment hinder the full utilization of

\footnotetext{
${ }^{7}$ Яцик А.В. Водогосподарська екологія: у 4 т., т.3. К.: Генеза, 2004. Кн. 5.496 с.
} 
agricultural potential of Ukraine. As of 2018, just about 510 thousand ha of agricultural lands are irrigated, which is $84 \%$ less than in 1990.

Much of the territory of Ukraine is located in the area of insufficient moisture. Global climate changes has led to a significant expansion of the territory with a lack of natural humidification. From 1990 to 2018, the area of arid and very arid zones in Ukraine increased by 8 million ha in comparison to the period of 1960-1990. Under these conditions, sustainable agriculture is impossible without irrigation.

The typical for the State Agency and its territorial bodies combination of functions in implementation of the state policy in the sphere of management, use, recovery of water resources and economic functions, such as meeting the needs of the population and sectors of the economy in water resources, conduction of the management of the objects of state property, ensuring the exploitation of state water economy objects and provision of the design, construction and reconstruction of the systems for protection against harmful effects of water, creates a base for the occurrence of conflicts of interests.

The parallel existence of two organizational structures (basin and administrative-territorial) increases the inefficiency of management and causes duplication and improper functioning, dispersion of limited resources (personnel, financial, material and technical and others), untimely response to the emergence of new management problems.

The structure and system of water management within river basins require the continuation of appropriate and proper organizational reform according to the basin principle, the introduction of the European governance model and the best world practices, and the system of management of the state water economy complex besides, in the part of providing with corresponding services, requires the introduction of marketbased foundations of the economic activity conduction.

The EU Water Framework Directive proposes a fundamentally new approach to the basin water management system ${ }^{8}$. The principle is that the main management unit is the water object pool. An integrated approach to water management enables balanced management and recovery of water resources, taking into account social, economic and environmental requirements and needs. The integrated approach coordinates the management of water resources in different sectors of the economy from local to international level. This approach involves incorporating more sophisticated water management system and more efficient institutional structure into the balanced water management process and legislative

\footnotetext{
${ }^{8}$ Директива 2000/60/СС Свропейського Парламенту і Ради «Про встановлення рамок діяльності Співтовариства в галузі водної політики» від 23 жовтня 2000 р. Режим доступу: http://zakon2.rada.gov.ua/laws/show/994_962
} 
framework, which is necessary for balanced management decisions. It is well known that the key principle of integrated water management is the basin principle. The National Target Program for the Development of Water Management and Environmental Improvement of the Dnipro River by 2021 in Ukraine provides for the implementation of a complex of measures concerning the introduction of the integrated water resources management system by the basin principle. Also, the Law of Ukraine «On the Fundamental Principles (Strategy) of the State Environmental Policy until 2020 », adopted in 2010, stipulates that the state administration system in the field of water protection needs urgent reform in the direction of transition to integrated water resources management by the basin principle 9 . The basin principle is defined as the complex integrated management of water resources within the river basin territory. The territory of the water basin may be the basin of one large river or, otherwise, include several basins of small rivers. Besides, the river basin territory can be located within one country as well as within several countries.

As the state of water resources depends directly on the quality of their management, environmental and water policy of the state, in 2016 the Law of Ukraine "On the Introduction into Some Legislative Acts of Ukraine on the Implementation of Integrated Approaches in Water Resources Management by the Basin Principle" was adopted ${ }^{10}$. This law has introduced into the existing legislation relevant concepts related to the basin principle of water resources management and additions, namely:

- the basin management principle - complex (integrated) water resources management;

- the river basin management plan - a document containing an analysis of the conditions and a complex of measures to achieve the objectives, set for each river basin district within the established time frame;

- the river basin district - the main unit of management for water use and protection and recovery of water resources, consisting of the river basin (adjacent river basins) and associated coastal and groundwater;

- the river basin (water intake) - a part of the earth's surface and a layer of soil, the runoff of water from which successively through connected reservoirs and streams is carried out into the sea, estuary or lake;

- the sub-basin - a part of the river basin, the runoff of water from which through the associated reservoirs and streams flows to the main river of the basin or water section downstream.

9 Закон України «Про основні засади (стратегію) державної екологічної політики до 2020 року». Прийняття від 21.12.2010. Режим доступу: https://zakon.rada.gov.ua/laws/show/ 2818-17.

10 Закон України «Про внесення до деяких законодавчих актів України щодо впровадження інтегрованих підходів в управлінні водними ресурсами за басейновим принципом» Прийняття від 04.10.2016 https://zakon.rada.gov.ua/laws/show/1641-19 
There are 9 river basin districts in Ukraine: the Dnipro River basin districts; the Dniester River Basin; the Danube River Basin; the Southern Buh River Basin; the Don River Basin; the Vistula River Basin; the river basin of Crimea; the Black Sea River Basin and the Azov River Basin District. Within the established river basin districts, the central executive body, which ensures the formation of state policy in the field of environmental protection, may allocate sub-basins. The boundaries of river basin districts, sub-basins and water economy plots are approved by the body of the central executive power, which ensures the formation of state policy in the field of environmental protection.

Water economy plots within river basin districts are allocated by taking into account the basin principle of management, administrative-territorial structure, physical and geographical conditions and economic activity, which ensures the formation of state policy in the field of environmental protection. The structure that manages the river basin is the Basin Council.

The Basin Council is a consulting and advisory body within the river basin territory, established under a body of the central executive power, which implements state policy in the field of water management, with the aim of ensuring the rational use and protection of waters and the recovery of water resources, integrated management of them ${ }^{11}$.

The planned basis of the basin management principle is a target program for the use, protection and recovery of water resources in the water intake basin, based on the normalization of anthropogenic load on them, requirements for water quality for the provision of the conservation of selfhealing ability and water regulation functions of rivers.

Interstate consulting bodies for integrated management of trans-boundary river basins are being formed to implement state-of-the-art computer systems for the support of management decisions under an integrated approach.

The guideline principles of the implementation of the basin management system in Ukraine should be:

- priority of ecological safety of water use and water consumption or priority of ecological policies of subjects of basin water use as the highest sector, corporate, local priorities and decisive factor of ecological improvement of the river basin, improvement of drinking water quality and sustainable development;

- basin co-ordination of environmental policies of basin management subjects and balance of their policies in the system of water use and water economy activity;

\footnotetext{
${ }^{11}$ Наказ Міністерства екології та природних ресурсів України від 26.01.2017 № 23 «Про затвердження Типового положення про басейнові ради». Режим доступу: https://zakon.rada.gov.ua/laws/show/z0231-17
} 
- self-sufficiency and self-compensation of the basin system of water use, water protection and recovery of water resources

- ecological and economic integrity of the system of water use, water protection and recovery of water resources;

- ensuring the interaction of basin management subjects on the basis of the program-based management method, integrated systematic approach and availability of the Main Basin Ecological and Economic Coordinator (Basin Council);

- standardization of the procedures and processes of basin management and normalization of the hierarchy of responsibility as guarantees of the efficiency of basin management and strengthening of responsibility for the quality of water resources and the conditions of water bodies of the basin;

- flexibility of organizational and legal structures and mechanisms in the basin management system, which can adequately adapt to the changing conditions of development (political, economic, legislative, productive and others);

- multivariant mechanisms of investment activity and financing of basin measures;

- the capability of the mechanism of stimulation of the efficiency and rational use of water and recovery of water resources;

- scientific substantiation of the management decisions and educational readiness for their implementation;

- complexity of the basin database and feedback efficiency (monitoring of the sustainable development of the basin).

The reform of the sphere of protection and recovery of water, rational use of water resources and development of water economy and land reclamation is being carried out, including reforming both the State Agency and enterprises, institutions and organizations belonging to the sphere of its management. The reform process will promote the coordinated development and management of water, land and other related resources within river basins, as well as achieving maximum social and environmental well-being on a fair basis, taking into account the interests of all water users in any part of the basin.

After the development and adoption of the new Law of Ukraine «About Water Users Consolidation», they will be created as non-profit public-law bodies and will be managed by their members to provide specialized irrigation and drainage services. A permanent consulting and advisory body of the Cabinet of Ministers of Ukraine - the National Council for the Protection, Recovery and Sustainable Management of Water Resources will be established to develop proposals and ensure coordination of actions of relevant associations of water users, bodies of local powers, enterprises, institutions and organizations involved in the use of natural resources in the river basins of Ukraine. 
In order to provide proper coordination of the activity of the bodies of state authorities in certain regions of the river basins of Ukraine, it is provided for the amendments to the current legislation of Ukraine to resubordinate the Basin Councils to the National Water Council. The main task of the National Water Council should be to implement integrated water basin management in accordance with the provisions of the EU Water Framework Directive and to implement methodological support for the creation of Basin Councils in the river basins and sub-basins.

With the financial support of the European Community, water management and flood protection projects are being developed and improved in the Dnipro, Tisza, Western Buh and Siverskyi Donets basins. In this regard, the State Agency of Ukraine actively cooperates with the Swedish Agency for International Development, within the framework of the TACIS program, NATO, the Danish Agency for Cooperation with Eastern Europe (DANCEE), the Swiss Confederation, Hungary, the USA, Poland and other countries. Further development of international cooperation will help to solve important problems directed to the improvement of the management, use and protection of water resources, as well as the approaching of the policies of Ukraine and the European Union in this field.

\section{CONCLUSIONS}

The existent nowadays system of water economy zoning and water resources management of Ukraine is based on two principles - hydrographic and administrative. The latter is even given the preference (many boundaries of water management plots are tied to the boundaries of administrative areas), because this principle was used to conduct public administration in the field of water use and protection and water resources recovery. The implementation of the basin management principle and the need to meet modern European requirements require the harmonization of the boundaries of water management areas with the boundaries of basins and sub-basins, which will be allocated within the territory of the country in accordance with the requirements of the EU Water Framework Directive.

\section{SUMMARY}

The article determines that Ukraine is one of the least well-supplied with water resources country among the European countries. Most natural water sources are scarce, and water resources of Ukraine are becoming a limiting factor in the development and distribution of productive forces. Due to the excessive anthropogenic load, disturbance of the conditions of river runoff formation and natural balance, which led to a decrease in the quality of water resources, the threatening ecological condition occurred in almost all river basins of Ukraine, and especially in the Dnipro basin - the main source of water supply in the country. More than $70 \%$ of the state's water supply is 
provided by the surface runoff of the Dnipro basin. Therefore, the issues of rational use of water resources, their recovery and protection are one of the main tasks of the state policy of Ukraine. Based on the analysis of the ecological conditions and hydro-chemical composition of the water of the basins of the major rivers of Ukraine, it was concluded that anthropogenic and technogenic load on aquatic ecosystems reached a critical limit due to extensive management and led to a significant reduction of ecological and sanitary expenditures and the depletion of water resources. As the state of water resources depends directly on the quality of their management, the environmental and water policy of the state, the article analyzes the existing legislative framework of Ukraine concerning the implementation of integrated approaches to water basin management. Principles that we consider to be the main guideline ones for the implementation of the basin management system in Ukraine are the following: priority of ecological safety, co-ordination of ecological policies of subjects of basin management, self-sufficiency and self-compensation of the basin system, ecological and economic integrity of the water system within the basin and process of standardization, scientific substantiation of management decisions, complexity of the basin database. It is proved that the implementation of the basin management principle requires taking into account the modern European requirements for harmonization of the boundaries of water areas with the borders of basins and sub-basins, which will be allocated in the territory of the country in accordance with the requirements of the EU Water Framework Directive.

\section{REFERENCES}

1. Постанова Верховної Ради України «Про Концепцію розвитку водного господарства України». Прийняття від 14.01.2000. Режим доступу: https://zakon.rada.gov.ua/laws/show/1390-14

2. Данилишин Б. М., Дорогунцов С. І., Міщенко В. С., Коваль Я. В., Новоторов О. С., Паламарчук М. М. Природно-ресурсний потенціал сталого розвитку України. К.: РВПС України, 1999. 716 с.

3. Дезірон О. В. Водокористування в Україні: сучасний стан та перспективи розвитку. Водне господарство Украӥни. К.: 2003, № 3-4. C. $4-8$.

4. Закон України «Загальнодержавна цільова програма розвитку водного господарства та екологічного оздоровлення p. Дніпро до 2021 року». Прийняття від 24.05.2012. Режим доступу: https://zakon.rada.gov.ua/laws/show/4836-17

5. Водний менеджмент в Україні: проблеми та інновації розвитку: [колективна монографія] /за ред. Л. Ф. Кожушко, В. А. Сташука, М. А. Хвесика, А. М. Рокочинського. Рівне, 2018. 638 с. 
6. Указу Президента України «Про програму інтеграції України в Європейський Союз». Прийняття від 10.07.2015. Режим доступу: https://zakon.rada.gov.ua/laws/show/n0001100-00.

7. Яцик А.В. Водогосподарська екологія: у 4 т., т.3. К.: Генеза, 2004. Кн. 5. 496 с.

8. Директива 2000/60/ЄС Європейського Парламенту і Ради «Про встановлення рамок діяльності Співтовариства в галузі водної політики» від 23 жовтня 2000 p. Режим доступу: http://zakon2.rada.gov.ua/laws/show/994_962

9. Закон України «Про основні засади (стратегію) державної екологічної політики до 2020 року». Прийняття від 21.12.2010. Режим доступу: https://zakon.rada.gov.ua/laws/show/2818-17.

10. Закон України «Про внесення до деяких законодавчих актів України щодо впровадження інтегрованих підходів в управлінні водними ресурсами за басейновим принципом» Прийняття від 04.10.2016 https://zakon.rada.gov.ua/laws/show/1641-19

11. Наказ Міністерства екології та природних ресурсів України від 26.01.2017 № 23 «Про затвердження Типового положення про басейнові ради». Режим доступу: https://zakon.rada.gov.ua/laws/show/ z0231-17

\section{Information about the author:} Stashuk V. A., Doctor of Engineering, Professor, Corresponding Member of NAAS, Institute of Irrigated Agriculture of the National Academy of Agrarian Sciences of Ukraine Kherson, Naddniprianske, 73483, Ukraine 


\section{SCIENTIFIC AND PRACTICAL ASPECTS \\ OF THE FORMATION OF ECOLOGICALLY SAFE SYSTEMS \\ OF IRRIGATED AGRICULTURE IN THE CONDITIONS OF THE SOUTH OF UKRAINE}

Vozhegova R. A.

\section{INTRODUCTION}

On the basis of the modeling of climate changes processes, conducted by the international team of the scientists of the Cambridge group under the aegis of the FAO UNO, further rise in the air temperature in the range from 2 to $6^{\circ} \mathrm{C}$ in the period until 2100 is predicted ${ }^{1}$. This increase in the temperature and $\mathrm{CO}_{2}$ concentration in the air will have a direct impact on the biosphere of the Earth, including the productivity of the agro-industrial complex, the yield and quality of products of crops. Negative climate changes in the nearest future include the rise in the air temperature, strengthening of the drought effects, reduction of snow cover, disturbance of the uniformity of precipitation distribution, which in complex will lead to the intensification of erosion processes and soils degradation.

Increasing drought of the climate has caused the need to change approaches to the formation of agricultural systems, especially in Southern Steppe of Ukraine. For the last 45 years, the amount of effective and positive temperatures during the vegetation period in this region has increased almost to $700^{\circ} \mathrm{C}$ that has prolonged its duration by 12-14 days ${ }^{2}$. At the same time, it should be noted that the productivity of the plant sector, as well as of the agriculture on the whole, strongly depends on the impact of climatic factors ${ }^{3}$.

Irrigation in the conditions of a severe deficit of natural moisture is one of the main factors of countering the negative effects of global warming and improving the productivity of the crop industry. Optimum interaction with other constituents of agriculture and complex mechanization favors to the intensive

\footnotetext{
${ }^{1}$ Наукові основи охорони та раціонального використання зрошуваних земель / за наук. ред. С. А. Балюка, М. І. Ромащенка, В. А. Сташука. Київ: Аграрна наук, 2009. 624 с.

2 Сніговий В. С. Проблеми землеробства й ефективність сучасного виробництва. Таврійський науковий вісник. 2003. Вип. 27. С. 29-33.

${ }_{3}^{3}$ Бабич А. О. Світові земельні, продовольчі і кормові ресурси. Київ: Аграрна наука, 1996. $133 \mathrm{c}$.
} 
use of heat, light, nutrients, moisture by plants that in the complex provides an effective use of land resources, promotes obtaining of high and sustainable yields of different by biological features and genetic potential crops ${ }^{4}$.

The use of irrigation causes fundamental changes in the natural ecosystems of the Steppe region - changes in soil moisture, decrease of the temperature and increase of the humidity of surface air, etc. Besides, there are a number of less noticeable, but no less important consequences - the change of mineral composition of soil, physical, physical-chemical and biological properties of different soil horizons. Experiments, conducted in recent times, show that because of the lack of sufficient environmental literacy of agricultural producers, proper control by the state bodies for the conditions of the environment, the lack of environmentally friendly equipment and agricultural technologies, the desire of getting the maximum number of agricultural products, even at the expense of the increase in the degree of intensity of the load on agricenoses, a threat of further critical deterioration of the ecological conditions of the irrigated ecosystems occurred ${ }^{5}$.

To prevent the undesirable consequences of agricultural activity, it is necessary to develop and apply a number of agro-technological measures: maintenance of crop rotations, cultivation of perennial forage herbs, differentiated methods of soil tillage, use of the varieties and hybrids with a resistance to the insects and diseases, use of biological methods for combating harmful organisms, etc. In the historical aspect, the attempts of farmers to overcome the negative impact on the environment through the application of fertilizers, lime, gypsum, irrigation or drainage, and other agricultural measures has been started at the BC times. However, their explanation, reasonable and rational use remain problematic even at the present time. Particularly noticeable impact on the environment is observed in the conditions of irrigation, when due to the receipt of a large amount of water at the application of artificial humidification, there is a significant transformation of almost all abiotic and biological components of agrocenosis that requires the use of absolutely different methodological approaches to the crop science.

In the countries of the European Union in recent years, certain attention is paid to the study of the impact of agromeliorative measures, including the simultaneous use of irrigation and fertilizers, considering the changes in environmental conditions, because in the modern conditions intensification of agricultural production needs the increase in the efficiency of agriculture,

\footnotetext{
${ }^{4}$ Силва Ж. Г., Нвазе К. Ф., Казин Э. Достижение нулевого голода. Критическая роль инвестиций в социальную защиту и сельское хозяйство. ФАО ООН. Рим, 2016. С. 12-14.

${ }^{5}$ Gathala M. K., Timsina J., Islam Md. S. Et cetera Conservation agriculture based tillage and crop establishment options can maintain farmers' yields and increase profits in South Asia's rice-maize systems. Evidence from Bangladesh. Field Crops Research. 2014 P. 85-98.
} 
rational use of water resources, optimization of the fertilizers use with a decrease in their negative impact on the environment and scientifically substantiated accounting of the needs in agricultural resources. These developments require a comprehensive approach with the development of the predictive models to assess the effect of water use on hydrological and hydrochemical conditions, the model of forecasting the balance of nitrogen, phosphorus, etc. Intensification of agricultural production on the meliorated lands leads to a decrease in the natural soil fertility due to the uptake by crops of nutrient and biologically active elements. Another problem is connected with soil salinity increase under the use of irrigation that could result in salinization and alkalination ${ }^{2}$.

The management of nutrition and salt regimes is an important task of agriculture and implies the use of technologies based on the modern achievements of science and technology for these purposes. Fertilizers and ameliorants in irrigated agriculture should be applied simultaneously with irrigation water, using the flow energy and the ability of water to dissolve them. In this case, their application could be subdivided and performed in the required quantities and in the necessary periods of vegetation that would provide the optimization of plants productive processes, prevent surface runoff and untimely decomposition of fertilizers and ameliorants substances.

During the twentieth century, irrigation has become widespread in the world, currently more than 345 million hectares are irrigated on the planet, which is $21 \%$ of the total arable land, on which it is produced more than $40 \%$ of all agricultural products, that is because the productivity of one irrigated hectare more than twice exceeds the yield of plant products of non-irrigated area. High efficiency of artificial humidification led to the solving the food security of mankind, as the rapid growth of irrigated lands has led to a significant reduction in the global food prices index from $2.2 \%$ in 1971-1980 years to $0.8 \%$ - in 20002005.

At the moment, due to the global climate change, which manifests itself in the increase of air temperatures, reduction of its relative humidity, reduction of the amount and disturbance of the uniformity of precipitation distribution, increase in the deficit of qualitative irrigation water makes for the necessity to use new methodological approaches to the organization of artificial humidification at both regional and micro-local levels ${ }^{6}$.

In many countries in the world, small farms do not have enough money, time, energy or water, because existing irrigation technologies are extremely resource consumptive. Soil tillage, fertilization, sowing, plant care, harvesting

\footnotetext{
${ }^{6}$ Asfaw S., Maggio G. Gender integration into climate-smart agriculture. Tools for data collection and analysis for policy and research. Food and Agriculture Organization of the United Nations. Rome 2016. 20 pp.
} 
requires large labor costs and time, diesel pumps need fuel, electric - connection to the networks and electricity, but sometimes water does not come to the root zone of plants, and, for example, evaporates into the air (at watering by sprinkler irrigation), runs off the fields (at surface way of watering), moves into deep layers of soil and becomes inaccessible (watering by flooding) ${ }^{7}$.

Intensive cultivation technologies make for the need to use large amounts of resources to obtain optimum levels of yields. Therefore, important scientific and practical significance has the application of innovative approaches to the formation of systems of agriculture on irrigated lands, which are based on the principles of water-and resource-saving, development of the norms for consumption of irrigation water, fertilizers, pesticides and biopreparations, considering the location of the root system of crops, the use of alternative energy sources, etc ${ }^{8}$.

Worldwide, agricultural water consumption is about $70 \%$ and energy consumption is about $30 \%$. Therefore, the questions of the reduction of costs of both irrigation water and energy during watering are strategic ones. Realizing that many agricultural producers are limited by resource supply, the scientists of agrarian science should offer a set of measures to save and minimize water consumption, energy, labor and resources through the development and testing of the latest technologies, existing on the considering the costs of these four resources, which may have an important value and increase the economic efficiency of irrigated agriculture ${ }^{9}$.

The world energy crisis, which has started in the second half of the twentieth century, resulted in the necessity of development and implementation of resource-saving, low-waste and zero-waste technologies in all sectors of the national economy, including crop production. Moreover, the questions of resource- and energy saving in the conditions of irrigation are particularly critical. Existing cultivation technologies no longer met the requirements of time, so the production required innovative resource-saving concepts, which would form the highest level of plant productivity, and also simultaneously in full volume would contribute to the saving water and other resources, would provide complete use of irrigation water and fertilizers by crops, etc. ${ }^{5}$.

Many studies have proved that the neglection of the elements of crop cultivation technologies and violation of the ecological balance in

\footnotetext{
${ }^{7}$ McCarthy N. Understanding agricultural households ' adaptation to climate change and implications for mitigation: land Management and investment options. Integrated Surveys on Agriculture. Washington D.C., USA: LEAD Analytics Inc. 2011 P. 42 - 47.

${ }^{8}$ Снеговой В. С., Гаврилица А. О. Орошение: от древнего искусства до современной науки. Кишинев: Штипнца, 1989. 135 с.

${ }^{9}$ Нетіс І. Т. Зміна клімату в зоні зрошення. Зроиуване землеробство. 1994. Вип. 39. C. $7-12$.
} 
agrolandscapes due to the neglection of all causative relations that ensure the functioning of ecosystems, causes the disruption of closed bicycles, destruction of the natural ability of main components to self-healing and in general to the reduction of the efficiency of irrigated agriculture. At the same time, at the expense of the positive influence of irrigation on the productive processes of plants in agrophytocenosis at high technological level of agriculture it is possible to increase yields 2-3 times, and in dry years - 4-5 times. Therefore, in our opinion, in order to obtain high and sustainable yields on irrigated lands, it is necessary to optimize the productive processes, to reduce expenditures of irrigation water per unit of plant products, to develop and apply modern cultivation technologies that comprehensively consider biological features of crops, the nature of their water consumption, have increased adaptability to weather conditions, and are characterized by high economic, energy and ecological parameters .

\section{The directions of the reduction of resource expenditures at artificial humidification in the South Steppe of Ukraine}

Mainly two methods of vegetation irrigation are used in the South of Ukraine - sprinkler over-head irrigation and irrigation by furrows. Sprinkler irrigation - by the means of machines DDA-100 MA, Fregat, DDN-45, Kuban, Valmont et al. In the future, combined methods of vegetation watering (for example, drip and aerosol - at the combination of the most economical benefits and ecological safety) will be used. Furrow irrigation is a simple and mostly cheap way, but it is more laborious and requires a particularly well-planned surface of the field. It can be used only if groundwater lays deep (not less than $2.0 \mathrm{~m}$ ). The watering furrows are made at the last row tillage, temporary canals and the output furrows - by the means of the canal-diggers KZU-0.3, KOR-500, etc. The better the field surface is planned (aligned), the greater the length of the watering furrows may be and the higher labor productivity of watering will be. If the field has the optimal slope (0.004-0.012) and is well-planned, the length of the irrigation furrows can be up to $200 \mathrm{~m}$ or more, and in the fields with a lower slope the furrows with the length of 50-100 m should be used.

The works of domestic and foreign scientists have found that in the conditions of irrigation, each crop, as well as some varieties and hybrids, have a biological reaction on a separate technological element, in particular, irrigation, mineral nutrition background, plants density, soil tillage system, etc. Therefore, there is a need to use high-productive varieties and hybrids of the intensive type, which are able to provide maximum manifestation and disclosure of potential genetically determined characteristics of plant productivity in the conditions of irrigation, in particular, at drip and micro-sprinkler irrigation, increased mineral 
nutrition, application of the systems of integrated plant protection and differentiated soil tillage.

Drip irrigation in 2-3 times decreases the cost of irrigation water per unit of sowing area, increases yields and improves the quality of plant products. However, the main advantage of this method of artificial humidification is saving resources and increasing their payback by the unit of additional yield. Drip irrigation due to its numerous advantages has been used for the first time over 100 years, but until nowadays it requires improvement and increase of its resource-saving direction. The system of precise agriculture, which includes the use of micro-irrigation (including drip irrigation), is an innovative technology that differs significantly from other irrigation technologies of crops. Its use provides the possibility to obtain the maximum yield of onion at the minimum expenditures. It is advisable at irrigation, along with the use of fertilizers, to use biopreparations for the optimization of the growth and development of plants, increase of their resistance to environmental conditions. Therefore, resourcesaving technologies of artificial humidification should be adapted to the unique features of each enterprise and region ${ }^{10}$.

Drip irrigation allows obtaining friendly sprouts and distribute the mineral fertilizers evenly in the root-zone layer. Distribution of watering norms by the days of cultivation of onions at drip irrigation is as follows: 1-30 day - 20$25 \mathrm{~m}^{3} / \mathrm{ha}$; $31-50$ day $-25-30 \mathrm{~m}^{3} / \mathrm{ha} ; 51-100$ day $-35-45 \mathrm{~m}^{3} / \mathrm{ha}$.

Unlike sprinkling, drip irrigation is based on the flow of water into the root zone of plants. The number and frequency of water supply is regulated according to the needs of plants. The water comes to every plant evenly. Unirrigated strips of the rows allow performing tillage, harvesting. At drip irrigation, the root system develops better than at any other type of irrigation, with a circle of the roots humidification is thicker. Drip irrigation is the most effective system for plants nutrition. The intensive absorption of nutrients is due to the greater development of the root system, complete humidification and at the expense of good soil aeration and the formation of new roots.

The use of drip irrigation systems simultaneously with the application of fertilizers in solution (so-called «fertigation»), allows you to constantly maintain the soil moisture in the optimum ratio in the system «water - air» in the soil that favors to a higher coefficient of fertilizers absorption by plants. At drip irrigation systems, precise dosing of all elements that are in the solution, including the control of nutrition soil regime, the simulation of fertilizer consumption and to setting their quantity for the planned yield level could be performed. Besides,

\footnotetext{
${ }^{10}$ Сніговий В. С., Жуйков Г. Є., Димов О. М. Економічні важелі еколого-безпечного ведення землеробства на зрошуваних землях Південного Степу. Агроекологічний журнал. Київ, 2003. С. 32-37.
} 
such a system allows to apply a balanced amount of nitrogen, phosphorus, potassium and other nutrients considering the growth stages. and the seasonal requirements of plants. Fertilization through drip systems increases the coefficient of their use by an average of $25-30 \%$, reduces the total use of fertilizers by $15-35 \%$. Fertigation, unlike a conventional drip irrigation, not only provides an efficient use of fertilizers, but helps to prevent contamination of groundwater, does not create conditions for secondary soil salinization and has valuable ecological and economic advantages.

Prospective ways for solving the problems of irrigated agriculture concerning resource conservation and increase of economic efficiency are the use of microirrigation and pumps working on solar power, which has significant agricultural, economic and environmental benefits (Fig. 1).

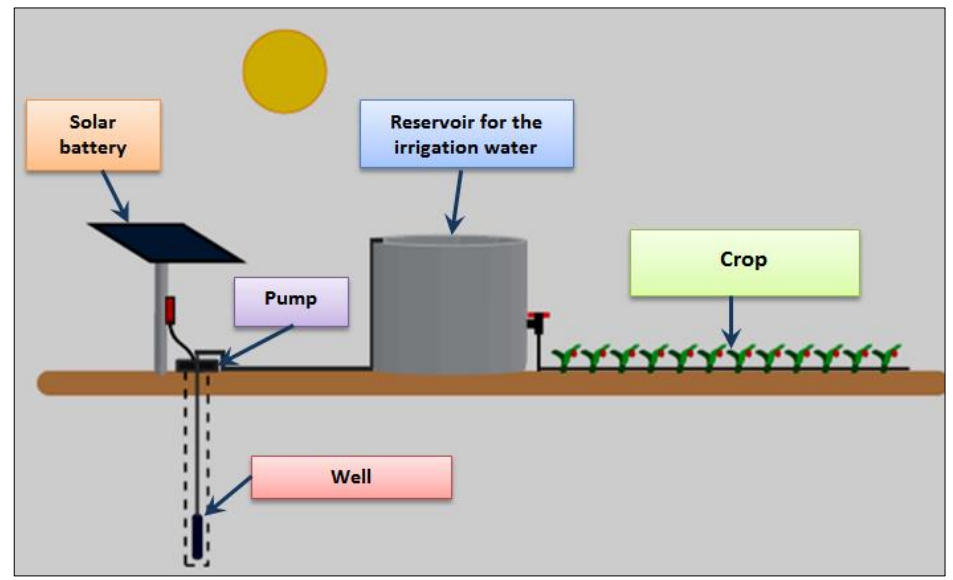

Fig. 1. The scheme of resource-saving irrigation system using solar energy ${ }^{11}$

To optimize irrigation and to reduce the expenditures of irrigation water and energy resources, it is necessary to develop and apply innovative systems of artificial humidification with the maximum simplification and low cost. Thus, the important value has the consideration of local irrigation conditions and irrigation area for the manufacturing of pumps.

In recent years, wide distribution was obtained by the pumps with a power of 40-200 Watts, which are used for the irrigation of small fields with

${ }^{11}$ Fischer R. A., Byerlee D., Edmeades G. O. Crop yields and Global Food Security: Will yield increase continue to feed the world? Australian Centre for International Agricultural Research. 2014. No. 158. P. 52 - 59. 
an area of 1000 to $5000 \mathrm{~m}^{2}$. In such conditions, it is possible to use solar batteries for power supply of such pumps and to compensate the expenditures for irrigation during one or two seasons of crops cultivation ${ }^{12}$.

\section{Scientific substantiation of crops cultivation technologies on the irrigated lands of the South of Ukraine}

Crops cultivation is connected with the action and interaction of many factors, that is testified by the influence of natural and anthropogenic conditions. At the level of each farm to improve the environmental friendliness of agrotechnical and melioration measures and agricultural methods, it is necessary to assess their impact on the soils and agroecosystems. In the South of Ukraine, the most effective measure of soil water regime improvement is artificial humidification, which allows to significantly increase the productivity of agriculture. Perennial field researches of the Institute of Irrigated Agriculture of the National Academy of Agrarian Sciences of Ukraine and other scientific institutions have proved that due to the artificial humidification it is possible to create favourable conditions for realization of potential possibilities of varieties and hybrids, and provide a substantial increase in gross production volumes per the unit of sowing area.

Increasing the efficiency of scientific research and competitiveness of scientific developments in the field of irrigated agriculture in southern region of Ukraine is a significant lever of stabilization of agricultural production in the arid climate and one of the priority directions of the state policy. The Institute of Irrigated Agriculture of NAAS has been developing and constantly improving the systems of irrigated agriculture in the areas of the Steppe zone, which allow to receive the 3-5 times higher yields in comparison to non-irrigated conditions, and irrigation regimes are oriented to the biological and genetic features of modern varieties and hybrids saving $15-40 \%$ of irrigation water actually without the loss of yields.

Theoretical developments on the optimization of soil processes on the irrigated lands substantiate the scientific bases of rational and environmentally-safe application of fertilizers and ameliorants. Wide distribution obtained the use of new resource-saving systems of crops fertilization, which every year are introduced in the areas of Kherson, Mykolaiv, Dnipropetrovsk regions on the area of 50 thousand ha and provided the reduction of expenditures for mineral fertilizers by $24-72 \%$, compared to the accepted norms. The developments of the Institute were included as a constituent part in the «Prospective plan for preservation and increase of fertility of soils in Kherson region».

12 Resource-Smart technology. Bridging the design gap between the developed and developing worlds. Url: https://www.ideglobal.org/story/resource-smart-technology (date of access 12.01.2019). 
Introduction of the developed by the Institute of Irrigated Agriculture of NAAS «Methods for determination of the payback of irrigation water and reimbursement for its supply» will increase the efficiency of the water supply complex and irrigated agriculture in southern region on the whole, providing the possibility of more rational allocation of funds.

The development of the Institute consists of scientific and technical base of agriculture conduction on the irrigated lands in southern region. In short crop rotations a system of soil-protective energy-saving soil tillage, which provides saving of fuel-lubricants materials (by 20\%) under a decrease in the energy intensity of the process (by 40\%), became widespread in the region.

The improved at the Institute crop cultivation technologies is being implemented on the irrigated lands in Kherson, Mykolaiv, Odesa and Dnipropetrovsk regions on the area (thousand hectares): winter wheat -150 , soybean - 35, vegetable crops - 25. Water-saving regimes of crops irrigation, which ensure saving of irrigation water and energy resources and obtaining 4.5-5.5 million UAH of pure profit, are used in the farms of Kherson, Mykolaiv, Dnipropetrovsk, Zaporizhzhya regions on the area of 300 thousand ha.

In the field experiments of the Institute of Irrigated Agriculture it was established that due to the best indexes of the bulk density, porosity and water permeability, the content of moisture at the time of the spring regrowth of winter crops and at the appearance of spring crops sprouts at different-depth systems of plowing and plowless tillage were 3.5-7\% higher than at the shallow single-depth system. Water consumption for the formation of one ton of products in all crop rotations was the lowest at the different-depth plowing and ranged from $723 \mathrm{~m}^{3} / \mathrm{t}$ in crop rotation with $75 \%$ share of cereals up to $973 \mathrm{~m}^{3} / \mathrm{t}$ under the reduction of the cereals share to $50 \%$ and up to $1100 \mathrm{~m}^{3} / \mathrm{t}$ - under the reduction to $25 \%$. This pattern is also observed at the systems of the different-depth and single-depth shallow plowless tillage with the decrease, respectively, by $5-10 \%$ and $50-60 \%$.

More favorable conditions for the accumulation of nutrients in the soil layer of $0-40 \mathrm{~cm}$ were created at the beginning of the spring vegetation of crops in the crop rotation with $75 \%$ share of cereals and on the background of the different-depth plowing basic tillage.

Replacement of plowing with the plowless deep basic tillage led to the decrease of the content of nitrates, mobile phosphorus and exchangeable potassium, respectively, by 10,17 and $8 \%$, and at the use of shallow plowless loosening these indexes were lower, respectively, by 27, 23 and $13 \%$. This pattern was observed in the crop rotation No. 1 with 25 and No. 2 with $50 \%$ share of cereals, at the same time, the indexes of the nutrients content were significantly lower.

The highest yield of crops and crop rotation productivity was provided by the crop rotation No. 3 with $75 \%$ share of cereals and $25 \%$ share of industrial crops at the different-depth plowing tillage, where its indexes 
averaged to $10.3 \mathrm{t} / \mathrm{ha}$, with a profit of 37.9 thousand $\mathrm{UAH}$ and profitability level of $187 \%$ (Fig. 2).

At the same time, a single-depth shallow one provided the level of profitability, which decreased to $103 \%$. In the first and second crop rotations, the profit and profitability level were significantly lower, at the same time, the regularity in regard to the methods and depths of the basic tillage saved.

In the field researches in the direction of the optimization of cultivation technology of new corn hybrids of different FAO groups at different ways of irrigation and quality of irrigation water, the level of mineralization, ion-salt composition of irrigation water and its irrigational assessment according to the DSTU-2730-2015 were made. Basic information on the economic efficiency of the complex action of new hybrids of corn, different ways of irrigation in the conditions of the Ingulets and Kakhovka irrigation systems was obtained.

It was found that under the watering with water of the Class II from the Ingulets irrigation system, the yield of corn hybrids decreased by $5-10 \%$, compared to the results of the studies obtained in the Kakhovka irrigated array (Table 1).

The highest grain yield of 14.1-18.8 t/ha was formed by the hybrids with FAO 380-430 Azov and Ararat, and at drip irrigation the absolute advantage was of the hybrid Aral, the grain yield of which increased to 18.7-19.0 t/ha.

One of the main factors of the intensification of production in irrigated agriculture is plant breeding developments. The Institute of Irrigated Agriculture creates the newest varieties and hybrids with genetically predetermined adaptability to the conditions of irrigation. Over 70 varieties and hybrids of winter wheat, soybean, corn, alfalfa, tomato and other crops have been created.

Winter wheat varieties have a potential yield of 8-11 t/ha of grain, and high adaptive ability. New alfalfa varieties combine high potentials of forage, seed and nitrogen-fixing productivity with wide adaptive abilities to the biotic and abiotic conditions of the environment, which can accumulate in the soil up to $0.27 \mathrm{t} / \mathrm{ha}$ of biological nitrogen. High-productive soybean varieties of different ripeness groups are created, with a yield level of 3.7-5.6 $\mathrm{t} / \mathrm{ha}$ of seeds, high protein content of $39-42 \%$ and fat content of $20-23 \%$. Besides, new varieties and hybrids have the advantage of resistance to diseases and lodging.

The work on the breeding of the main crops - winter wheat, corn, soybean, tomato, alfalfa, etc. is carried out at the high level at the Institute. The GMO-free varieties and hybrids are created, which is a significant competitive advantage for Ukraine, the EU countries and for other countries in the world, and it allows to obtain plant products, which are qualified as 
ecologically safe, has an increased demand on the domestic and foreign markets.

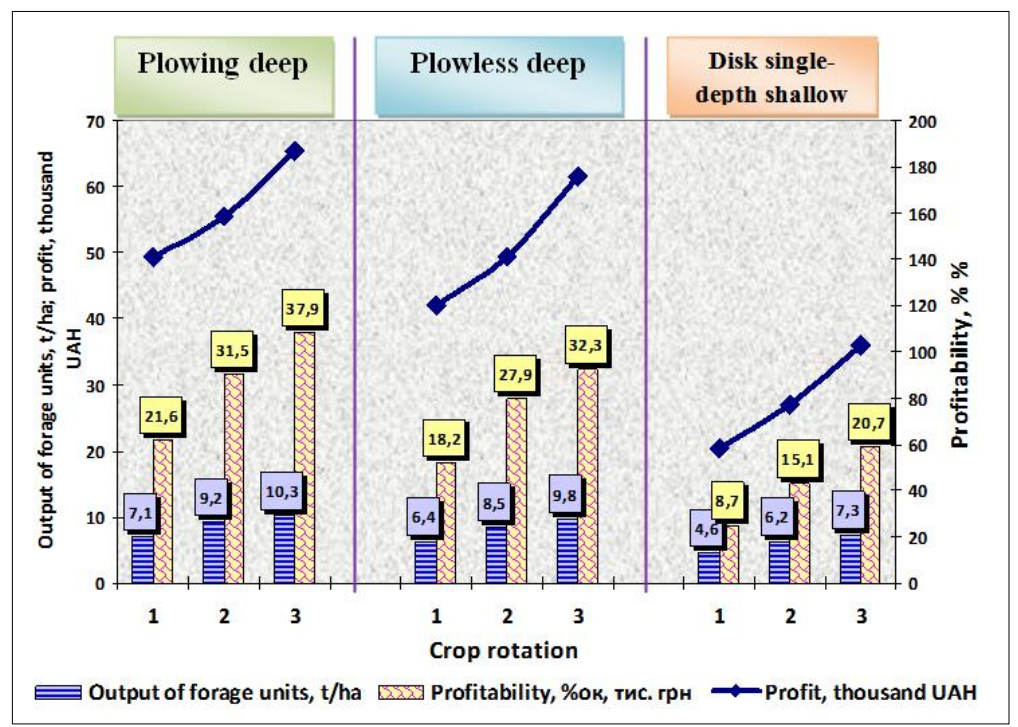

Fig. 2. Productivity and cost-effectiveness indexes of the crop rotation functioning under different soil tillage systems

The development of seed-breeding systems at the Institute is the result of a long-term work in the field of biotechnology with the development of the principles of a potato seed system creation for the irrigated conditions of the South of Ukraine through the obtaining original material by the combination of new scientific approaches.

New directions of agricultural development are the introduction of organic farming systems, the cultivation technologies of unconventional (socalled «niche») and drought-resistant crops, adapted to the regional climatic conditions. The new crop, which is examined by the scientists of the Institute, is a perennial vegetable plant - asparagus. This vegetable, especially its young shoots, has a great value by the gourmets throughout the world, and is one of the most delicious vegetable crops. The Institute created a unique and only in Ukraine variety of sweet white clover, which has a high forage and seed productivity, increased drought resistance, high capacities of phytoremediation, resistance to pests and pathogens infestation. There also 
are the field experiments on the cultivation of saffron seed, which has great prospects for the introduction on the irrigated lands of the South of Ukraine.

Table 1

The grain yield of corn hybrids at different ways of irrigation and irrigation regimes, $t /$ ha (average for 2016-2018)

\begin{tabular}{|c|c|c|c|c|c|c|}
\hline № & Hybrid & FAO & $\begin{array}{c}\text { Irrigation } \\
\text { with DDA } \\
\mathbf{1 0 0 M A ,} \\
\text { Ingulets } \\
\text { irrigation } \\
\text { array, TAW } \\
\text { at 80\% FC }\end{array}$ & $\begin{array}{c}\text { Drip } \\
\text { irrigation, } \\
\text { Ingulets } \\
\text { irrigation } \\
\text { array, TAW } \\
\text { at 85\% FC }\end{array}$ & $\begin{array}{c}\text { Drip } \\
\text { irrigation, } \\
\text { Kakhovka } \\
\text { irrigation } \\
\text { array, TAW } \\
\text { at 85\% FC }\end{array}$ & $\begin{array}{c}\text { Irrigation } \\
\text { with } \\
\text { Zimmatic, } \\
\text { Kakhovka } \\
\text { irrigation } \\
\text { array, TAW } \\
\text { at 80\% FC }\end{array}$ \\
\hline 1 & DN Pivikha & 190 & 9.75 & 10.10 & 10.76 & 10.57 \\
\hline 2 & Oberih & 190 & 10.61 & 11.00 & 12.10 & 11.54 \\
\hline 3 & Hawtyn & 250 & 12.61 & 12.29 & 13.41 & 13.97 \\
\hline 4 & Galateya & 250 & 12.21 & 11.91 & 13.46 & 12.71 \\
\hline 5 & Korund & 280 & 12.38 & 12.64 & 12.54 & 12.42 \\
\hline 6 & Rostok & 300 & 12.93 & 14.81 & 15.65 & 12.85 \\
\hline 7 & Zbruch & 350 & 12.77 & 14.87 & 15.20 & 12.81 \\
\hline 8 & Vizyr & 350 & 10.61 & 11.43 & 11.72 & 11.48 \\
\hline 9 & Kakhovskyi & 350 & 11.23 & 13.72 & 13.28 & 11.37 \\
\hline 10 & Azov & 380 & 14.09 & 14.25 & 15.34 & 14.57 \\
\hline 11 & Rava & 420 & 14.65 & 15.81 & 16.27 & 14.38 \\
\hline 12 & Arabat & 430 & 14.30 & 18.71 & 18.95 & 14.83 \\
\hline & LSD & & 0.37 & 0.56 & 0.42 & 0.44 \\
\hline
\end{tabular}

The efficiency of agricultural technologies on the irrigated lands is confirmed by their large-scale introduction. In the South of Ukraine, the developed soil tillage system is applied on the area of 200-215 thousand ha. Resource-saving system of fertilization of crops using optimal parameters of the content of nutrients in the soil is implemented on the area of 57.5 thousand ha. At the same time, resource saving on average amounted to $150 \mathrm{UAH} / \mathrm{ha}$. In Kherson region, the cultivation technology of tomato with application in the technological process of own varieties is introduced. It has provided the maximum fruit yield of $115 \mathrm{t} / \mathrm{ha}$, with the dry matter content in fruit up to $7 \%$. The volume of introduction - 1600-2500 ha with the prospects of further its expansion to 10 thousand hectares.

In Ukraine as in other countries of the world there is a critical issue of adaptation of agriculture to the climate change, which manifests itself in drought, increase in temperature and disturbance of uniformity of precipitation distribution. On the basis of the above-mentioned facts, it should be noted that in the context of regional climate change in the South of Ukraine, it is necessary to perform a continuous monitoring of the main agrometeorological indexes, analyze and forecast their changes according to 
the data of the meteorological stations of the region, determine the directions of climate change and make forecasts of changes for 5, 10, 20-year periods.

Considering previous indicators of the climate change, the agrarian scientists should expand directions, program of scientific researches on adaptation of agricultural system to new agroecological situation, which envisages the following:

- Conducting of deep researches on the issues of zoning of territories for crops cultivation on the basis of estimation of natural agroclimatic resources;

- To create new varieties and hybrids of crops with the optimum adaptability to arid conditions and regional climate changes;

- Reduction of share of plow-land and increase of the areas using agromeliorative measures;

- To continue research on the soil formation processes, development of soil fertility preservation measures and prevention of soil degradation;

- Reconstruction and building of new irrigation systems and development of irrigated agriculture, as a guarantor of sustainable yields, effective development of the agrarian sector and rural areas in the zone of irrigation.

\section{CONCLUSIONS}

1. In the conditions of climate change in the irrigated agriculture of Ukraine it is necessary to use intensive technologies of crops cultivation, which are based on the use of innovative principles with the optimization of different methods of irrigation and irrigation regimes, fertilization systems, tillage and plant protection. The structure of acreage and crop rotations on the irrigated lands of Ukraine for rational use of the irrigated lands and prevention of the negative influence of external factors of natural and anthropogenic nature are proposed.

2. The methodological and methodical approaches to the integrated estimation of the irrigated lands for their rational use, prevention of development of the degradation processes, protection and recovery of soil fertility are developed. The resource-saving cultivation technologies of different by the biological characteristics in accordance with the project normative expenses, which are specified by the scientists of the Institute of Irrigated Agriculture and other scientific institutions of NAAS, are improved, scientific approaches to the state-private partnership in the system and management of water resources are proposed, the instruments of the state support and regulation of entrepreneurial activity in the field of irrigated agriculture are determined.

3. For the scientific substantiation for the nearest prospects, the issues of the reduction of all types of resource losses at irrigation and other elements of agrotechnologies in the conditions of global climate change will be of a particular importance. It is required to work out new scientific approaches regarding the application of innovative technologies of drip irrigation on the 
basis of minimization of water, energy, labor and money expenditures, regulation of irrigation water, fertilizers, pesticides and biopreparations, considering the location of the root system of crops to determine the optimal irrigation norms, use of solar energy as an alternative energy source, etc.

4. In the conditions of regional climate change, a great scientific and practical significance will have the research on the zoning of the territories for crops cultivation on the basis of the assessment of natural agroclimatic resources, creation of crops varieties with the optimum adaptability to arid conditions and regional climate changes, reduction of the share plow-land and increase in the areas using agro-meliorative measures, optimization of nutrition regime of soil. Besides, the development and introduction of a system of measures, also at the level of the state, which are directed to the reconstruction of the existing and building of new irrigation systems, development of irrigated agriculture with the aim of the development of the agrarian sector and rural areas in the zone of irrigation.

\section{SUMMARY}

In the conditions of climate change in the irrigated agriculture of Ukraine, it is required to use intensive crops cultivation technologies, which are based on the use of innovative approaches with the optimization of different methods of irrigation and irrigation regimes, fertilization systems, soil tillage and plant protection. The structure of acreage and crop rotations on the irrigated lands of Ukraine for the rational use of irrigated lands and prevention of the negative influence of external factors of natural and anthropogenic nature are suggested. The methodological and methodical approaches to the integrated assessment of the irrigated lands for their rational use, prevention of the development of degradation processes, protection and recovery of soil fertility are developed. The improved resource-saving cultivation technologies of different by the biological properties crops in accordance with the project normative expenses defined by the scientists of the Institute of Irrigated Agriculture and other scientific institutions of NAAS, are proposed, the scientific approaches to the stateprivate partnership in the system and management of water resources are determined, the instruments of the state support and regulation of entrepreneurial activity in the field of irrigated agriculture are suggested.

\section{REFERENCES}

1. Наукові основи охорони та раціонального використання зрошуваних земель / за наук. ред. С. А. Балюка, М. І. Ромащенка, В. А. Сташука. Київ: Аграрна наук, 2009. 624 с.

2. Сніговий В. С. Проблеми землеробства й ефективність сучасного виробництва. Таврійський науковий вісник. 2003. Вип. 27. С. 29-33.

3. Бабич А. О. Світові земельні, продовольчі і кормові ресурси. Київ: Аграрна наука, 1996. 133 с. 
4. Силва Ж. Г., Нвазе К. Ф., Казин Э. Достижение нулевого голода. Критическая роль инвестиций в социальную защиту и сельское хозяйство. ФАО ООН. Рим, 2016. С. 12-14.

5. Gathala M. K., Timsina J., Islam Md. S. et cetera Conservation agriculture based tillage and crop establishment options can maintain farmers' yields and increase profits in South Asia's rice-maize systems. Evidence from Bangladesh. Field Crops Research. 2014. P. 85-98.

6. Asfaw S., Maggio G. Gender integration into climate-smart agriculture. Tools for data collection and analysis for policy and research. Food and Agriculture Organization of the United Nations. Rome, 2016. $20 \mathrm{p}$.

7. McCarthy N. Understanding agricultural households' adaptation to climate change and implications for mitigation: land management and investment options. Integrated Surveys on Agriculture. Washington D.C., USA: LEAD Analytics Inc. 2011. P. 42-47.

8. Снеговой В. С., Гаврилица А. О. Орошение: от древнего искусства до современной науки. Кишинев: Штипнца, 1989. 135 с.

9. Нетіс I. T. Зміна клімату в зоні зрошення. Зрошуване землеробство. 1994. Вип. 39. С. 7-12.

10. Сніговий В. С., Жуйков Г. С., Димов О. М. Економічні важелі еколого-безпечного ведення землеробства на зрошуваних землях Південного Степу. Агроекологічний журнал. Київ, 2003. С. 32-37.

11. Fischer R. A., Byerlee D., Edmeades G. O. Crop yields and global food security: Will yield increase continue to feed the world? Australian Centre for International Agricultural Research. 2014. No. 158. P. 52-59.

12. Resource-smart technology. Bridging the design gap between the developed and developing worlds. URL: https://www.ideglobal.org/story/ resource-smart-technology\# (дата звернення 12.01.2019).

\section{Information about the author:} Vozhegova R. A., Doctor of Agricultural Sciences, Professor,

Corresponding Member of NAAS, Vice-head of the Plant Breeding Department, Institute of Irrigated Agriculture of the National Academy of Agrarian Sciences of Ukraine Kherson, Naddniprianske, 73483, Ukraine 
DOI https://doi.org/10.36059/978-966-397-154-4/216-231

\section{PHYTOSANITARY CONDITIONS OF WINTER CEREAL CROPS ON THE IRRIGATED LANDS OF THE SOUTH OF UKRAINE DEPENDING ON THE AGROMETEOROLOGICAL CONDITIONS OF THE YEAR}

\section{Zaiets S. O.}

\section{INTRODUCTION}

One of the most significant reasons, which destabilize the production of grain and worsen its quality both on irrigated and non-irrigated lands of the South of Ukraine is a significant infestation of plants by fungal diseases, the losses of yield from them reach $20-30 \%$, and in the years of epiphytoties they are even higher ${ }^{1,2,3,4}$.

In recent years, phytopathological situation with crops in the South of Ukraine has slightly changed. In most cases, this is due to the climate change. Firstly, there are quite extreme-arid weather conditions observed before and after the sowing period of winter cereal crops. Secondly, the late cessation of the autumn vegetation of plants (this period is prolonged by 12 - 15 days) and early regrowth (in the third decade of February - early March), accompanied by sharp fluctuations in the night (minus) and daytime (plus) air temperatures. Under such conditions, additional tillering occurs on the winter crops, plants weaken, and extreme (dry) conditions in the spring period of vegetation lead to a change in the phytopathologic condition of the crops.

If in the South of Ukraine in the 80-90s of the last century winter cereal crops were mainly infested by smut diseases, brown rust and powdery mildew, then in the last decade - the agents of the leaf spotting: winter

\footnotetext{
1 Коваленков В.Г. Усложняющаяся фитосанитарная ситуация требует новых решений. Защита и карантин растений. 2010. 7. С.4-7.

${ }_{2}^{2}$ Ретьман С. В. Плямистості пшениці в Лісостепу України й концептуальні основи захисту: автореф. дис. на здобуття наук. ст. доктора с.-г. наук: спец. 06.01.11 «Фітопатологія». К., 2009. 43 с.

3 Судникова В. П. Создание исходного материала для селекции пшеницы на устойчивость к Septoria tritici Rob. et Desm. Пути решения проблем повышения адаптивности, продуктивности и качества зерновых и кормовых культур: Материалы междунар. практич. конф. Самара, 2003. С. 103.

${ }_{4}^{4}$ Samobor V. Effect of powdery mildew attack on guality parameters and experimental bread baking of wheat. Acta agriculturae Slovenica. 2006. B. 87, № 2. P. 381-391.
} 
wheat by Septoria spot (Septoria tritici Desm.), and winter barley by net blotch (Drechslera teres lto) ${ }^{5}$.

Therefore, researches on the monitoring of the main phytopathogens of winter cereal crops on the irrigated lands of the South of Ukraine, as well as identification of the most plastic varieties to them, are very relevant.

\section{Agrometeorological conditions of the spring-summer period of winter crops vegetation in 2016, 2017 and 2018}

Field experiments were conducted in 2016 - 2018 on the irrigated lands of the Institute of Irrigated Agriculture of NAAS. The soils are darkchestnut, slightly alkaline, middle-loamy, with humus content of $2.3 \%$. The bulk density of a meter layer of the soil is $1.37 \mathrm{~g} / \mathrm{cm}^{3}$. The field capacity (FC) is $20.3 \%$ of the weight of the completely dry soil, and the wilting point (WP) is $9.1 \%$. Meteorological parameters that determined the weather conditions of the spring-summer period of winter cereal crops in 2016, 2017 and 2018 were taken from the observations of the Regional Center of Hydrometeorology in Kherson ${ }^{6,7}$. Distinctive feature of the vegetative period of cereal crops in 2016 was sufficiently high amount of precipitation: in March - $19.5 \mathrm{~mm}$, April - $56.8 \mathrm{~mm}$; May - $71.7 \mathrm{~mm}$ and June - $43.0 \mathrm{~mm}$ (Table 1). During the vegetative period (from April to June) was $171.5 \mathrm{~mm}$ of precipitation, which is by $52.9 \mathrm{~mm}$ more than the norm. A slightly different situation was observed in 2017 and 2018 years. Only in April of 2017 and March of 2018 there were more precipitation than the norm: 60.4 and $35.2 \mathrm{~mm}$, respectively. In the other months, there was a significant shortage of precipitation and high temperatures, especially in 2018. For April - June 2018, there was $60.4 \mathrm{~mm}$ of precipitation, which is $58.2 \mathrm{~mm}$ less than the norm.

The level of the provision with water of winter cereal crops during the vegetative period was determined by the humidity coefficient. Its indexes in moderately humid $(25 \%)$ by precipitation 2016 year was 0.70 , while the perennial norm is 0.40 . In 2017, the humidity coefficient during the vegetation period was 0.59 , which is more than by 0.19 over the norm. And in 2018 , the humidity coefficient was the least and averaged to 0.12 . Therefore, to maintain moisture in the soil layer of $0-50 \mathrm{~cm}$ at the level of $70 \% \mathrm{FC}$, it was enough to

\footnotetext{
${ }^{5}$ Бублик Л.І., Васечко Г.І., Васильєв В.П. та ін. Довідник із захисту рослин. За ред. М.П. Лісового. Київ: Урожай, 1999. 744 с.

${ }_{6}^{6}$ Агрометеорологічний бюлетень по території Херсонської області за першу, другу і третю декади вересня, жовтня і листопада 2015 p. № № 25-33. URL: http://khersonpogoda.ks.ua.

7 Агрометеорологічний бюлетень по території Херсонської області за 2016, 2017 і 2018 pp. № №1-33. Режим доступ URL: http://khersonpogoda.ks.ua.
} 
carry out only water-charging irrigation with the norm of $500 \mathrm{~m}^{3} /$ ha in 2016 , and there was a need in two and three vegetation watering irrigation with the norm of 800 and $1350 \mathrm{~m}^{3} /$ ha in 2017 and 2018 , respectively.

Table 1

Meteorological conditions of the vegetative period of 2016, 2017 and 2018 in comparison to the average perennial indexes for 1945-2010

\begin{tabular}{|c|c|c|c|c|c|c|}
\hline \multirow[b]{2}{*}{ Month } & \multicolumn{6}{|c|}{ Indexes } \\
\hline & $\begin{array}{c}\text { Average air } \\
\text { temperature, } \\
{ }^{\circ} \mathrm{C}\end{array}$ & $\begin{array}{l}\text { Relative air } \\
\text { humidity,\% }\end{array}$ & $\begin{array}{c}\text { Amount of } \\
\text { precipitation, } \\
\text { mm }\end{array}$ & $\begin{array}{c}\text { Evaporation, } \\
\text { Mm }\end{array}$ & $\begin{array}{c}\text { Water } \\
\text { deficiency, } \\
\text { Mm }\end{array}$ & $\begin{array}{l}\text { Humidity } \\
\text { coefficient }\end{array}$ \\
\hline \multicolumn{7}{|c|}{ Moderately humid by precipitation 2016 year } \\
\hline March & 6.3 & 78 & 19.5 & 38.7 & 19.2 & 0.50 \\
\hline April & 12.6 & 71 & 56.8 & 73.8 & 17.0 & 0.77 \\
\hline May & 16.1 & 76 & 71.7 & 73.3 & 1.6 & 0.98 \\
\hline June & 22.1 & 68 & 43.0 & 127.8 & 84.8 & 0.34 \\
\hline $\begin{array}{c}\text { For IV - } \\
\text { VI }\end{array}$ & 16.9 & 71.7 & 171.5 & 274.9 & 103.4 & 0.70 \\
\hline \multicolumn{7}{|c|}{ Moderate by precipitation 2017 year } \\
\hline March & 7.0 & 73 & 5.1 & 49.8 & 44.7 & 0.10 \\
\hline April & 9.3 & 72 & 87.9 & 59.3 & -28.6 & 1.48 \\
\hline May & 16.3 & 64 & 25.6 & 110.5 & 84.9 & 0.23 \\
\hline June & 22.0 & 61 & 10.3 & 147.1 & 136.8 & 0.07 \\
\hline $\begin{array}{c}\text { For IV - } \\
\text { VI }\end{array}$ & 15.9 & 65.7 & 123.8 & 316.9 & 193.1 & 0.59 \\
\hline \multicolumn{7}{|c|}{ Moderately dry by precipitation 2018 year } \\
\hline March & 1.5 & 75 & 61.2 & 31.6 & -29.6 & 1.94 \\
\hline April & 14.1 & 58 & 1.6 & 115.6 & 114.0 & 0.01 \\
\hline May & 19.5 & 59 & 35.7 & 146.1 & 110.4 & 0.24 \\
\hline June & 22.9 & 51 & 23.1 & 202.4 & 179.3 & 0.11 \\
\hline $\begin{array}{c}\text { For IV - } \\
\text { VI } \\
\end{array}$ & 18.8 & 56.0 & 60.4 & 464.1 & 403.7 & 0.12 \\
\hline $\begin{array}{c}\text { Perennial } \\
\text { norm } \\
(1945- \\
2010) \\
\end{array}$ & 15.5 & 66.7 & 118.6 & 299.7 & 181.1 & 0.40 \\
\hline
\end{tabular}

\section{Phytosanitary conditions of new winter wheat varieties} on the irrigated lands depending on the meteorological conditions

Winter wheat is one of the main food crops in the structure of the croplands of private and collective farms of Southern Steppe of Ukraine. Its yield and grain quality depends on many factors, among which one of the most important is the phytosanitary condition of crops $^{8}$. Our researches are dedicated to the

8 Заєць С.О., Коваленко О.А., Василенко Р.М. та ін. Ресурсозберігаючі екологічно безпечні технології вирощування озимих зернових культур, сої i кукурудзи на зрошуваних землях півдня України. Наукові основи адаптації систем землеробства до змін клімату в Південному Степу України: монографія; за наук. ред. чл.-кор. НААН Р. А. Вожегової. Херсон: ОЛДІ-ПЛЮС, 2018. С. 500-574. 
investigation of the phytosanitary condition of new and modern varieties of winter wheat when it is cultivated after soybean in the conditions of irrigation and to the detection of the most tolerant (resistant) to common fungal diseases among them. The varieties of winter wheat Ovidii, Ledia, Maria, Konka, Burgunka and Anatoliya, which are included in the State Register of plant varieties, suitable for distribution in Ukraine since 2009, 2016, 2013, 2014, 2015 and 2015, respectively, were sown. All the varieties of winter wheat were created at the Institute of Irrigated Agriculture of NAAS. The varieties of Ovidii and Ledia have a spine-free type of ear, and other varieties are spiny ones. It was established that in the conditions of 2016, 2017 and 2018 at irrigation the greatest harm for the wheat was caused by fungal diseases of leaves and stems, among the most widespread and harmful diseases were causative agents of septoriosis (Septoria tritici Desm.), pyrenophorosis (Drechslera tritici-repentis Died.), powdery mildew (Blumeria graminis (DC) Speer.) and yellow rust (Puccinia striiformis) (photo 1).

However, the monitoring of phytosanitary condition showed that in all the years of the research, the plants of winter wheat were infested by septoriosis (S. Tritici Desm.), while other diseases appeared only in certain years.

In agrometeorological conditions of 2016, the plants of winter wheat varieties were infested by the pathogens of septoriosis ( $S$. Tritici Desm.) and pyrenophorosis (D. Tritici-repentis Died.). Depending on the variety, spreading of these diseases at the earing stage, respectively, was 51.5-72.5 and $61.0-65.5 \%$, and the development -24.0-44,0 and 26.0-34.0\% (Table. 2). The greatest manifestation of septoriosis on the leaves was on the variety Ovidii, where the spreading rate reached $72.5 \%$, and the development $44.0 \%$. Tolerance (resistance) to damage of the leaves by septoriosis was on the varieties of Konka and Anatoliya, in which the development of this disease was 24 and $26 \%$, respectively.

Maria and Burgunka were the most resistant varieties to the damage of the leaves by pyrenophorosis, on which the prevalence of disease, respectively, was 62.0 and $61.0 \%$, and the development -26.0 and $28.0 \%$. The most affected by this disease were plant varieties of spine-free type Ovidii and Ledia, on which the development of this disease was 32 and 34\%, and the prevalence -65.5 and $64.0 \%$.

In the conditions of irrigation in 2017, the plants of winter wheat were affected by the leave form of septoriosis ( $S$. Tritici) and powdery mildew (B. Graminis), but to a lesser extent than in 2016. Therefore, the spreading and development of these diseases in 2017 was not significant and, correspondingly, it was $19.1-39.7$ and $0.9-2.0 \%$. 
Table 2

Spreading and development of fungal diseases on the leaves of winter wheat plants depending on the variety and agrometeorological conditions of the year

\begin{tabular}{|c|c|c|c|c|c|c|c|c|c|c|c|c|}
\hline \multirow{4}{*}{ Variety } & \multicolumn{12}{|c|}{ During the earing-milk ripeness of grain } \\
\hline & \multicolumn{4}{|c|}{2016} & \multicolumn{4}{|c|}{2017} & \multicolumn{4}{|c|}{2018} \\
\hline & \multicolumn{2}{|c|}{ I* } & \multicolumn{2}{|c|}{ II* } & \multicolumn{2}{|c|}{$I^{*}$} & \multicolumn{2}{|c|}{ III* } & \multicolumn{2}{|c|}{ I* } & \multicolumn{2}{|c|}{ IV* } \\
\hline & $\mathbf{R} * *$ & $\mathbf{R} * *$ & $\mathbf{P} * *$ & $\mathbf{R} * *$ & $\mathbf{R} * *$ & $\mathbf{R} * *$ & $\mathbf{P} * *$ & $\mathbf{R} * *$ & $\mathbf{R}_{*}^{*}$ & $\mathbf{R} *$ & $\mathbf{P} * *$ & $\mathbf{R} * *$ \\
\hline Ovidii & 72.5 & 44.0 & 65.5 & 32.0 & 39.7 & 1.9 & 0 & 0 & 100 & 6.3 & 5.0 & 1.0 \\
\hline Ledia & 64.0 & 30.0 & 64.0 & 34.0 & 30.8 & 1.1 & 0 & 0 & 100 & 2.8 & 2.0 & 0.05 \\
\hline Mar & & & 2.0 & 20 & 39. & 2. & 3.0 & 1.8 & 100 & 5.9 & 2.0 & 0.04 \\
\hline Konka & 1.5 & 24. & 3.0 & 30.0 & 19. & 0.9 & 2.2 & 1.6 & 100 & 4.3 & 0 & 0 \\
\hline Burgunk: & 5.0 & 32.0 & 1.0 & 28.0 & 33. & 1.5 & 2.7 & 1.6 & 100 & 2.3 & 100 & 2.0 \\
\hline Anatoliya & 52.5 & 26.0 & 62.5 & 30.0 & 25.7 & 1.9 & 0.6 & 1.1 & 100 & 3.8 & \begin{tabular}{|l|}
100 \\
\end{tabular} & 3.2 \\
\hline $\begin{array}{c}\bar{X} \bar{X} \mathrm{~S}_{\mathrm{X}}^{-} \\
\mathrm{S}_{\mathrm{X}}^{-} S_{\bar{X}}^{-}\end{array}$ & $\begin{array}{c}60.7 \\
\pm 3.7\end{array}$ & $\begin{array}{r}32.3 \\
\pm 3.1\end{array}$ & $\begin{array}{c}63.0 \\
\pm 0 \\
6\end{array}$ & $\begin{array}{c}30.0 \\
\pm 1 \\
2\end{array}$ & $\begin{array}{c}31.9 \\
\pm 8.4\end{array}$ & $\begin{array}{c}1.6 \pm \\
0.5\end{array}$ & $\begin{array}{c}1.4 \pm \\
1.4\end{array}$ & $\begin{array}{c}30.0 \\
\pm 1 \\
2\end{array}$ & $\begin{array}{l}100 \\
\pm 0\end{array}$ & $\begin{array}{c}4.2 \pm \\
1.7\end{array}$ & $\begin{array}{l}34.8 \\
\pm 75\end{array}$ & $\begin{array}{c}1.0 \pm \\
2.0\end{array}$ \\
\hline $\mathrm{V}, \%$ & 14.8 & 23.3 & 2.51 & 9.43 & 25.7 & 29.9 & 2.51 & 96.5 & 0 & 38.1 & 145 & 125 \\
\hline
\end{tabular}

Note: * I-Septoria tritici Desm.), II-Pyrenophorosis (Drechslera tritici-repentis Died.), III-Powdery mildew (Blumeria graminis (DC) Speer.); IV - Yellow rust (Puccinia striiformis Wesst).

$* * P$-prevalence of disease, $\% ; R$-disease development, $\%$.

The most distribution of septoriosis disease has reached 39.7 and $39.6 \%$ on the varieties of Ovidii and Maria with the development of the disease of 1.9 and $2.0 \%$, respectively. On the varieties of Konka, Ledia and Burgunka, the development of this disease was the least and at the earing stage, respectively, it was $0.9,1.1$ and $1.5 \%$.

The causative agent of mildew (B. Graminis) affected the plants of the spiny varieties of winter wheat Maria, Konka, Anatoliya and Burgunka, where the spreading and the development of this disease, respectively, was $3.0 ; 2.2 ; 2.7$ and $0.6 \%$ and $1.8 ; 1.6 ; 1.6$ and $1.1 \%$. The spine-free plant varieties Ovidii and Ledia were not affected by powdery mildew.

In 2018, the plants of winter wheat were also affected by septoriosis (S. Tritici), the distribution of which in all the varieties reached $100 \%$ at the stage of grain ripeness. But the development of this disease was insignificant, and fluctuated from 2.3 to $6.3 \%$ in dependence on the variety. This year, the infestation of winter wheat plants by the causative agent of yellow rust (Puccinia striiformis) was fixed, which development on the varieties Burgunka and Anatoliya was 2.0 and $3.2 \%$. On the variety of Konka, the disease of yellow rust was not found, and on all the other varieties there was an insignificant its manifestation.

On average for three years of the research on the plants of winter wheat, the development and spreading of septoriosis disease (S. Tritici) depended on the biological properties of the variety and averaged to $56.9-70.7 \%$ and $9.7-17.4 \%$ (Fig. 1). 


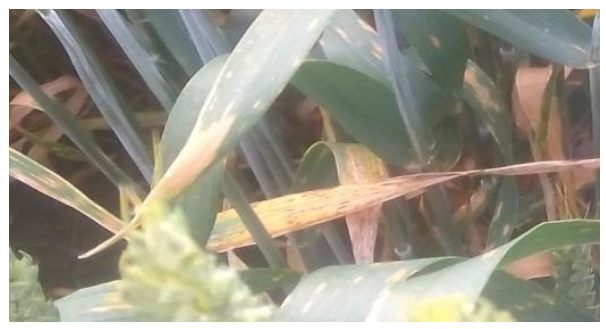

Septoriosis of leaves (Septoria tritici Desm.)

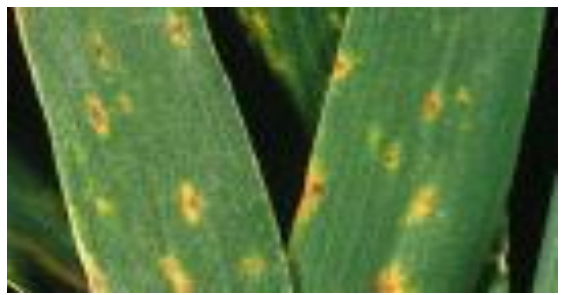

Pyrenophorosis of leaves (Drechslera tritici-repentis Died.)

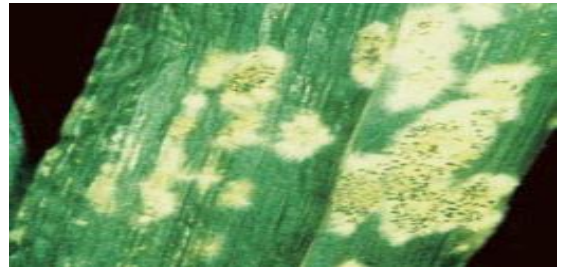

Powdery Mildew (Blumeria graminis (DC) Speer.)

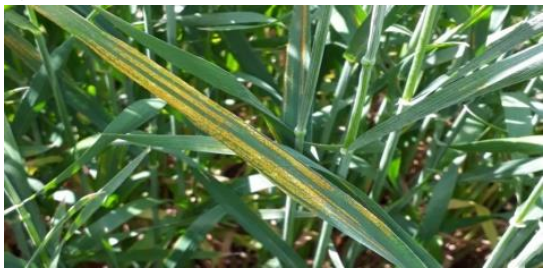

Yellow Rust (Puccinia striiformis Wesst)

Photo 1. Diseases of winter wheat at irrigation in the conditions of 2016-2018 


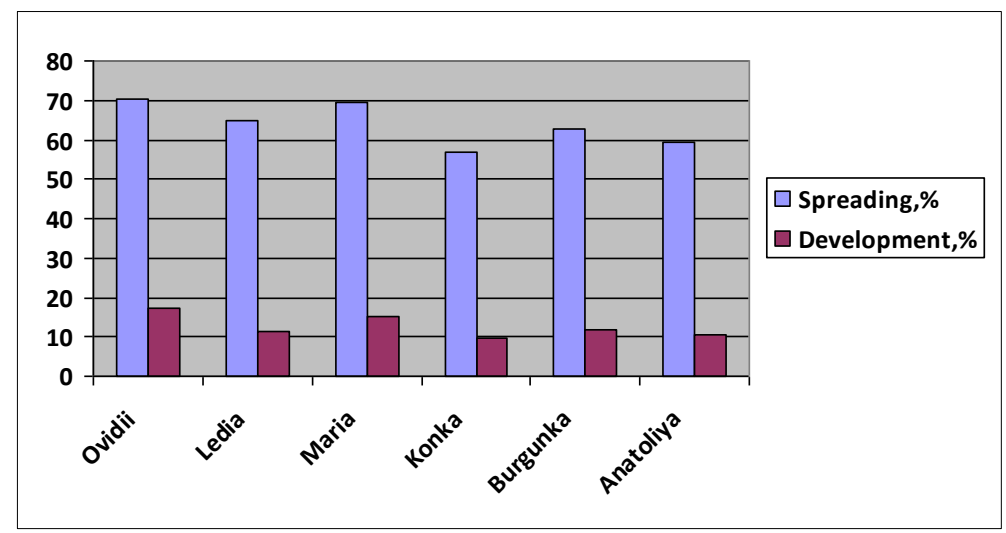

Fig. 1. The spreading and development of septoriosis ( $S$. Tritici Desm.) on the leaves of the winter wheat plants depending on the variety, (average for 2016-2018)

The least infestation with the disease was on the plant varieties Konka and Anatoliya, and the most - on Ovidii. The results of the grain yield evaluation showed that its level was influenced by the degree of propagation and development of the diseases. Taking into account that in 2016 winter wheat varieties Konka and Anatoliya were more resistant to septoriosis, and the variety Maria to pyrenophorosis, they provided the higher yields of 7.43, 7.38 and $7.50 \mathrm{t} / \mathrm{ha}$ (Table. 3 ).

Table 3

Yields of new and modern winter wheat varieties depending on the development of fungal diseases, $t / \mathrm{ha}$

\begin{tabular}{|c|c|c|c|c|c|}
\hline No. & Variety & $\mathbf{2 0 1 6}$ & $\mathbf{2 0 1 7}$ & $\mathbf{2 0 1 8}$ & $\begin{array}{c}\text { Average for 2016- } \\
\mathbf{2 0 1 8}\end{array}$ \\
\hline 1 & Ovidii & 6.88 & 6.41 & 7.41 & 6.90 \\
\hline 2 & Ledia & 7.24 & 6.74 & 6.92 & 6.97 \\
\hline 3 & Maria & 7.50 & 7.06 & 7.83 & 7.46 \\
\hline 4 & Konka & 7.43 & 7.16 & 7.56 & 7.38 \\
\hline 5 & Burgunka & 7.29 & 7.20 & 7.87 & 7.45 \\
\hline 6 & Anatoliya & 7.38 & 7.07 & 7.04 & 7.16 \\
\hline
\end{tabular}

$L S D_{05}$, t/ha $0.37 ; 0.26 ; 0.36 ; 0.14$.

While the less resistant to the diseases variety Ovidii formed by 0.50 $0.62 \mathrm{t} / \mathrm{ha}$ lower yield, which was $6.88 \mathrm{t} / \mathrm{ha}$, on the other investigated varieties Burgunka and Ledia, which were more resistant to spotting than Ovidii, 
grain yield, respectively, reached 7.29 and $7.24 \mathrm{t} / \mathrm{ha}$, which is 0.41 and $0.36 \mathrm{t} / \mathrm{ha}$ higher.

A similar situation on the formation of grain yield of the varieties of winter wheat was observed under the phytosanitary conditions of 2017. That is, varieties Konka and Burgunka, which are more resistant to fungal diseases, provided a higher yield of 7.16 and 7.20 t/ha, respectively. Less resistant to these diseases variety Ovidii formed 0.75 and 0.79 t/ha lower yield, which averaged to $6.41 \mathrm{t} / \mathrm{ha}$.

On the other investigated varieties Anatoliya and Maria, which were more resistant to the disease than Ovidii, 7.07 and $7.06 \mathrm{t} / \mathrm{ha}$ of grain yield was obtained, which is 0.66 and $0.65 \mathrm{t} / \mathrm{ha}$ higher. The variety of spine-free type Ledia, although more resistant to septoriosis and powdery mildew, but formed the yield of $6.74 \mathrm{t} / \mathrm{ha}$, which is $0.32-0.42 \mathrm{t} / \mathrm{ha}$ less than of the spiny varieties. This can be explained by the fact that this variety is ripening later, and it is falling under the «fire» of high air temperatures.

Taking into account that in 2018 the plants of Burgunka variety were not considerably affected by septoriosis and yellow rust, it provided the highest yield of $7.87 \mathrm{t} / \mathrm{ha}$. The lowest yield of grain of $6.92 / \mathrm{ha}$ was formed by the variety Ledia, due to its later ripening and getting under the «fire» of high air temperatures, because the percentage of disease infestation was not high.

On the other studied varieties Maria, Konka, Ovidii and Anatoliya, due to the more infestation by the causative agent of septoriosis, in comparison to the variety Burgunka, we obtained by $0.04,0.31,0.46$ and $0.83 \mathrm{t} / \mathrm{ha}$ lower yield of grain, respectively, which was 7.83, 7.56, 7.41, and 7.04 t/ha. However, the significant grain losses were provided by the varieties Ovidii, Ledia and Anatoliya. Almost the same yield in this year was by the formed varieties Maria, Burgunka and Konka. These varieties on average of three years of the research provided the highest yield levels - 7.46, 7.45 and $7.38 \mathrm{t} / \mathrm{ha}$. The lowest yield of grain of $6.90 \mathrm{t} / \mathrm{ha}$ was collected on the variety Ovidii, which was the most susceptible to infestation with fungal diseases of leaves among all the varieties.

\section{The phytosanitary condition of new varieties of winter barley on the irrigated lands depending on the meteorological conditions}

Barley is one of the most valuable fodder cereal crops. Ukraine entered into the four largest producers of this crop. It should be noted that over the past 15 years, the sown area of barley in Ukraine decreased by 2.3 times: from 5.8 million hectares (2003) to 2.5 million hectares (2018). However, the proportion of winter barley among cereal crops increased, while the share of spring barley was considerably reduced. Significant areas of sowing 
are concentrated in the South of Ukraine in Odesa, Mykolaiv and Kherson regions, where almost every year over 400 thousand ha are sown. According to the state Statistics Service of Ukraine, in 2018 the sowing area of winter barley was 872.6 thousand hectares, and yields were $3.35 \mathrm{t} / \mathrm{ha}$. Although the yield of barley increased by $68 \%$, it is almost two times lower than the yield in the EU countries.

One of the reasons leading to the loss of grain yield is the infestation and damage of the plants by harmful organisms ${ }^{9}$. Variety breeding, which are resistant against the defeat of fungal diseases, is of a great importance in the protection of winter barley ${ }^{10,11}$. In recent years, breeders of scientific institutions of the National Academy of Agrarian Sciences of Ukraine have created a number of varieties of typical winter and alternate types, which are distinguished not only by the increased frost-, or heat resistance, but also are more resistant to common diseases.

Therefore, the purpose of the research was to determine the phytosanitary condition of modern and new varieties of winter barley during the cultivation after soybean in the conditions of irrigation and the establishment among them the most resistant to common fungal diseases. Monitoring of phytosanitary conditions was conducted on the varieties of winter barley Aivengo, Akademichnyi, Burevii, Deviatyi Val, Dostoinyi and Snigova Koroleva, which are included into the State Register of plant varieties, suitable for distribution in Ukraine, respectively, in 2011, 2011, 2013, 2014, 2006 and 2014.

All of the studied winter barley varieties were created at the Selective Genetic Institute - The National Center for Seed and Varietal Studies of NAANS. The varieties Akademichnyi and Burevii are typical winter, and Aivengo, Deviatyi Val, Snigova Koroleva, and Dostoinyi are of alternate type.

It should be noted that in all the years of the research plants of winter barley varieties were infested by net blotch (Drechslera teres lto), and in the certain years - rhynchosporosis (Rhynchosporium graminicola Heinsen), powdery mildew (Blumeria graminis Speer) and yellow rust (Puccinia striiformis West) (Photo 2).

${ }^{9}$ Біловус Г.Я. Плямистості ячменю та заходи 3 обмеження їх розвитку в умовах Лісостепу України: автореф. дис. на здобуття наук ступеня канд. с.-г. наук: спец. 06.01.11 «Фітопатологія». К., 2006. 19 с.

10 Ковальский И.Д., Унтила И.П., Рожкован В.В., Караджова Л.В. Доноры устойчивости ярового ячменя к болезням в условиях Молдавской ССР. Съезд генетиков и селекционеров Молдавии. Кишинев: Штиинца, 1981. С. 81-82.

${ }^{11}$ Кузнецова Т.Е. Селекция ячменя на устойчивость к болезням. Краснодар, 2006. 288 с. 
The most spreading and development among the spot disease of leaves was in 2016, under the agrometeorological conditions in which the plants of winter barley were infested by net blotch (Drechslera teres 1to) and stripe (Drechslera graminea lto) helmintosporosis. Dostoinyi was not resistant to net blotch among the varieties of barley, on which the development of the disease reached $50 \%$ (Table 4). Slightly fewer were infestations by stripe helmintosporosis (D. teres lto) on the varieties Akademichnyi and Aivengo, on which the development of the disease was 46 and 44\%, respectively. The best resistance to net blotch was marked on the variety Deviatyi Val, where the development of the disease was $20 \%$ with the spreading of $58 \%$.

Barley stripe (D.Graminea lto) infested the plants of varieties Burevii, Aivengo, Akademichnyi and Dostoinyi, on which the development of the disease was 34, 32, 30 and 30\%, and the spreading - 67, 64, 69 and 63.5\%, respectively. Higher resistance to stripe had the varieties Deviatyi Val and Snigova Koroleva, on which the disease development was 26 and 28\%, respectively.

In the agrometeorological conditions of 2017 under the conduction of vegetative watering of the plants of winter barley, the plants were infested by net blotch (D. teres 1to) and rhynchosporosis (Rhynchosporium graminicola Heinsen), the distribution and development of which was 50.6-76.6\% and 2.0-10.6\%, respectively. The variety Dostoinyi was less resistant to net blotch, on which the spreading of the disease $76.6 \%$, and the development of the disease was $10.6 \%$. The varieties Deviatyi Val and Aivengo were tolerant to the causative agent of this disease - at the distribution of 50.6 and $54.0 \%$ the development averaged to 8.2 and $2.0 \%$, respectively.

The variety Dostoinyi was also less resistant to rhynchosporosis ( $R$. graminicola Heinsen), on which the maximum prevalence and development of this disease was observed, that is, respectively, 81.4 and $16.1 \%$. In agrometeorological conditions of 2018 , there was a need of three vegetation watering, which contributed to the spreading of such pathogens of fungal diseases: net helmintosporosis (Drechslera teres lto), powdery mildew (Blumeria Graminis Speer) and yellow rust (Puccinia striiformis West).

Manifestation of the pathogens of net helmintosporosis (D. teres LTO) and powdery mildew (B. Graminis Speer) on the plants of all winter barley varieties in the conditions of 2018 reached $100 \%$. As in the previous years, the maximum development of this disease was on the plants of the variety Dostoinyi, on which it averaged to $45.8 \%$. The varieties Aivengo and Burevii were resistant to net helmintosporosis (D. teres lto), on which the least development of this disease was fixed -3.4 and $6.0 \%$. 


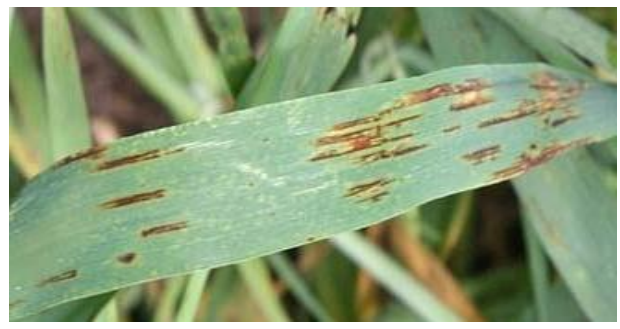

Net blotch (Drechslera teres Ito)

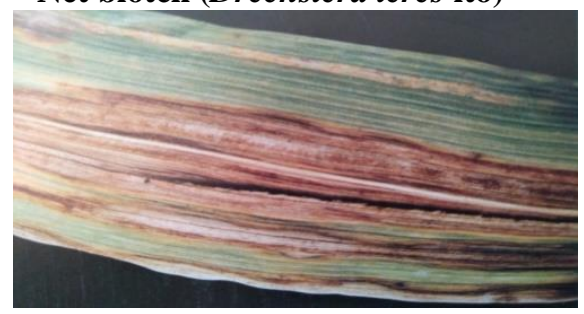

Barley stripe (Drechslera graminea lto),

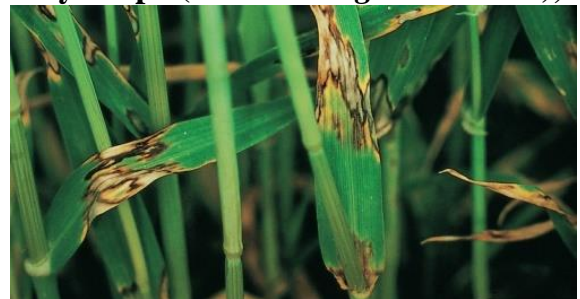

Rhynchosporosis blight (Rhynchosporium graminicola Heinsen)

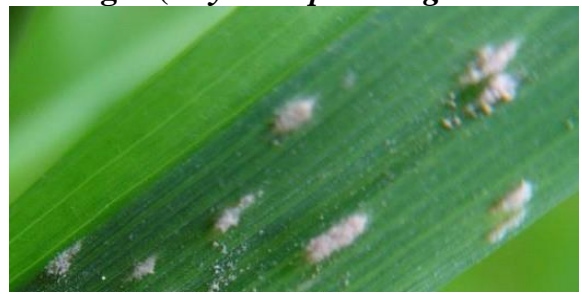

Powdery Mildew (Blumeria graminis Speer)

Photo 2. Diseases of winter barley at irrigation in the conditions of 2016-2018 
Table 4

The spreading and development of fungal diseases on the leaves of the winter barley varieties in 2016, 2017 and 2018

\begin{tabular}{|c|c|c|c|c|c|c|c|c|c|c|c|c|c|c|}
\hline \multirow{4}{*}{ Variety } & \multicolumn{14}{|c|}{ At the earing stage } \\
\hline & \multicolumn{4}{|c|}{2016} & \multicolumn{4}{|c|}{2017} & \multicolumn{6}{|c|}{2018} \\
\hline & \multicolumn{2}{|c|}{$\mathrm{I}$} & \multicolumn{2}{|c|}{ II } & \multicolumn{2}{|c|}{ I } & \multicolumn{2}{|c|}{ III } & \multicolumn{2}{|r|}{ I } & \multicolumn{2}{|c|}{ IV } & \multicolumn{2}{|c|}{$\mathrm{V}$} \\
\hline & $\mathrm{R} * *$ & $\mathrm{R} * *$ & $\mathrm{R} * *$ & $\mathrm{R} * *$ & $\mathrm{R} * *$ & $\mathrm{R} * *$ & $\mathrm{P} * *$ & $\mathrm{R} * *$ & $\begin{array}{c}\mathrm{P} * \\
*\end{array}$ & $\begin{array}{c}\mathrm{R} * \\
*\end{array}$ & $\begin{array}{c}\mathrm{P} * \\
*\end{array}$ & $\begin{array}{c}\mathrm{R} * \\
*\end{array}$ & $\mathrm{P} * *$ & $\begin{array}{c}\mathrm{R} * \\
*\end{array}$ \\
\hline Aivengo & 73.5 & 44 & 64.0 & 32 & 54.0 & 2.0 & 63 & 10.7 & 100 & 3.4 & 100 & 2.4 & 13.2 & 0.13 \\
\hline Akademichnyi & 76.5 & 46 & 69.0 & 30 & 59.7 & 8.6 & 63.6 & 4.8 & 100 & 14.4 & 100 & 1.8 & 5.1 & 0.19 \\
\hline Burevii & 63.0 & 28 & 67.0 & 34 & 56.6 & 3.5 & 67.6 & 6.6 & 100 & 6.0 & 100 & 2.8 & 10.3 & 0.14 \\
\hline Deviatyi Val & 58.0 & 20 & 59.5 & 26 & 50.6 & 8.5 & 68.3 & 15.2 & 100 & 7.4 & 100 & 2.9 & 100 & 5.0 \\
\hline Dostoinyi & 79.0 & 50 & 63.5 & 30 & 76.6 & 10.6 & 81.4 & 16.1 & 100 & 45.8 & 100 & 3.0 & 15.4 & 0.26 \\
\hline $\begin{array}{c}\text { Snigova } \\
\text { Koroleva }\end{array}$ & 73.0 & 42 & 67.5 & 28 & 60.0 & 5.6 & 65 & 10.1 & 100 & 4.2 & 100 & 2.5 & 100 & 6.9 \\
\hline $\begin{array}{c}\bar{X} \bar{X}_{ \pm} \mathrm{S}_{\mathrm{X}}^{-} \mathrm{S}_{\mathrm{X}}^{-} \\
S_{\bar{X}}^{-}\end{array}$ & $\begin{array}{c}70.5 \\
\pm \\
3.3\end{array}$ & $\begin{array}{c}38.3 \\
\pm \\
4.8 \\
\end{array}$ & $\begin{array}{c}65.0 \\
\pm \\
1.4 \\
\end{array}$ & $\begin{array}{c}30.0 \\
\pm 1 \\
2 \\
\end{array}$ & $\begin{array}{c}59.6 \\
\pm \\
8.8 \\
\end{array}$ & $\begin{array}{c}6.4 \\
\pm \\
3.2 \\
\end{array}$ & $\begin{array}{c}68.2 \\
\pm \\
6.6 \\
\end{array}$ & $\begin{array}{r}10.6 \\
\pm 4.4\end{array}$ & $\begin{array}{l}100 \\
\pm 0\end{array}$ & $\begin{array}{l}13.5 \\
\pm 15\end{array}$ & $\begin{array}{l}100 \\
\pm 0\end{array}$ & $\begin{array}{c}2.6 \pm \\
0.4\end{array}$ & $=\begin{array}{l}40,7 \\
\pm 48\end{array}$ & $\begin{array}{l}2.1 \pm \\
3.2\end{array}$ \\
\hline $\mathrm{V}, \%$ & 11.6 & 30.5 & 5.3 & 9.4 & 15.2 & 51.4 & 10.0 & 42.5 & 0 & 120 & 0 & 17.2 & 113 & 144 \\
\hline
\end{tabular}

Note: *I-net blotch (Drechslera teres lto), II - barley stripe (Drechslera graminea lto), III - rhynchosporosis (Rhynchosporium graminicola Heinsen); IV-powdery mildew (Blumeria graminis Speer); $V$-yellow rust (Puccinia striiformis West) $* * P$ - prevalence of disease, \%; $R$-disease spreading, $\%$.

The development of powdery mildew (B. Graminis Speer) on the plants of winter barley varieties was insignificant. But the maximum of its development the disease also gained on the variety Dostoinyi $-3.0 \%$. Less infested by mildew among all the varieties was Akademichnyi, on which the development averaged to $1.8 \%$.

Also, in 2018 on the winter barley crops we observed slight manifestation of the disease caused by the causative agent of yellow rust (Puccinia striiformis Wesst).

On average for the years of the research, on the plants of winter barley the development of the pathogen of net helmintosporosis (D. teres 1to) depended on the characteristics of the variety and was $69.5-85.2 \%$ and $12.0-35.5 \%$, respectively (Fig. 2).

The varieties Deviatyi Val and Burevii were more resistant to this disease, the spreading of the disease on which, respectively, averaged to 69.5 and $73.2 \%$, and the development -12.0 and $12.5 \%$. The plants of the variety Dostoinyi were non-resistant to the pathogen of net helmintosporosis (D. teres lto).

It was established that the level of grain yield depended on the spreading and development of the fungal diseases.

Taking into account that in the agrometeorological conditions of 2016 the variety of winter barley Deviatyi Val was more resistant to net blotch, 
and Snigova Koroleva - to barley stripe, they provided the highest yield of 6.97 and $7.27 \mathrm{t} / \mathrm{ha}$, respectively (Table. 5).

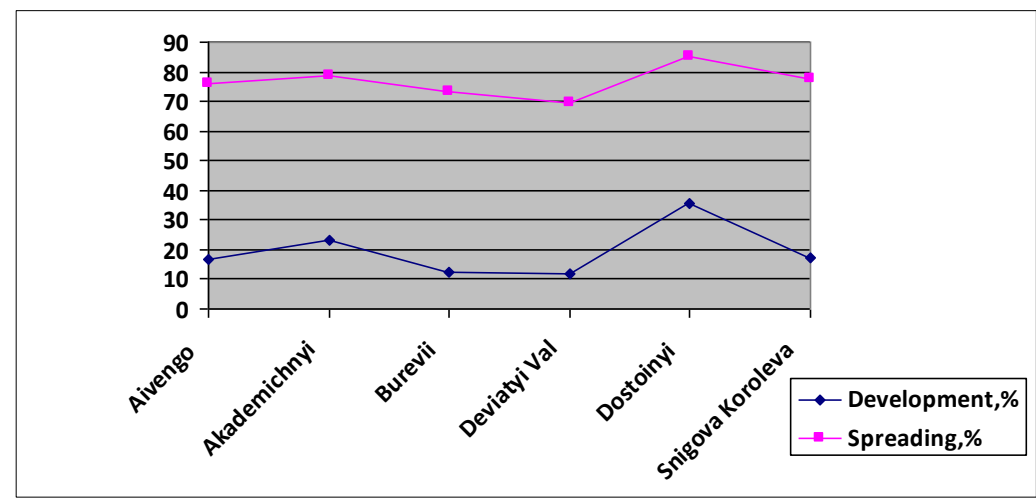

Fig. 2. The spreading and development of net blotch (Drechslera teres lto) on the leaves of the plants of winter barley depending on the variety, (average for 2016-2018)

Table 5

Yield of new and modern varieties of winter barley depending on the development of fungal diseases, $\mathrm{t} / \mathrm{ha}$

\begin{tabular}{|c|c|c|c|c|c|}
\hline No. & Variety & 2016 & 2017 & 2018 & $\begin{array}{c}\text { Average for 2016- } \\
2018\end{array}$ \\
\hline 1 & Aivengo & 6.39 & 6.80 & 7.82 & 7.00 \\
\hline 2 & Akademichnyi & 6.67 & 6.46 & 7.53 & 6.89 \\
\hline 3 & Burevii & 6.02 & 6.41 & 7.36 & 6.60 \\
\hline 4 & Deviatyi Val & 6.97 & 6.58 & 7.17 & 6.91 \\
\hline 5 & Dostoinyi & 5.69 & 6.18 & 6.62 & 6.16 \\
\hline 6 & $\begin{array}{c}\text { Snigova } \\
\text { Koroleva }\end{array}$ & 7.27 & 6.31 & 7.17 & 6.92 \\
\hline
\end{tabular}

$L S D_{05}$, t/ha $0.97 ; 0.24 ; 0.43 ; 0.34$.

While less resistant to these diseases variety Dostoinyi formed significantly lower yield, which was $5.69 \mathrm{t} / \mathrm{ha}$, that is 1.58 and $1.28 \mathrm{t} / \mathrm{ha}$ less than of the varieties snigova Koroleva and Deviatyi Val.

On the varieties Akademichnyi, Aivengo and Burevii we harvested, respectively, 6.67, 6.39 and $6.02 \mathrm{t} / \mathrm{ha}$ of grain, which is by $0.98,0.70$ and $0.33 \mathrm{t} / \mathrm{ha}$ higher than on the variety Dostoinyi. But the additional yield of 
0.70 and $0.33 \mathrm{t} / \mathrm{ha}$, received on the varieties of Aivengo and Burevii, was mathematically not significant $\left(\mathrm{LSD}_{05}\right.$ is $0.97 \mathrm{t} / \mathrm{ha}$ ).

The similar influence of the pathogens of fungal diseases on the formation of winter barley yield was observed in 2017. That is, the varieties Aivengo, Deviatyi Val and Akademichnyi, which are more resistant to net helmintosporasis and rhynchosporosis, provided higher yields of $6.80,6.58$ and $5.46 \mathrm{t} / \mathrm{ha}$, respectively. While less resistant to these diseases variety Dostoinyi formed significantly lower yield, which was $6.18 \mathrm{t} / \mathrm{ha}$, that is by $0.62,0.40$ and $0.28 \mathrm{t} / \mathrm{ha}$ less than of the varieties Aivengo, Deviatyi Val and Akademichnyi ( $\mathrm{LSD}_{05}$ is equal to $0.24 \mathrm{t} / \mathrm{ha}$ ).

The analysis of the results of the grain yield in 2018 showed that on the varieties of winter barley Aivengo, Akademichnyi and Burevii, the development of the disease of net helmintosporosis, powdery mildew and yellow rust was much lower than their harmful threshold. Therefore, compared to other varieties, they provided higher yield, which was 7.82, 7.53 and $7.36 \mathrm{t} / \mathrm{ha}$, respectively.

While less resistant to these diseases variety Dostoinyi formed significantly lower yield, which was $6.62 \mathrm{t} / \mathrm{ha}$, that is by $1.2,0.91,0.74,0.55$ and $0.55 \mathrm{t} / \mathrm{ha}$ less than of the varieties Aivengo, Akademichnyi, Burevii, Deviatyi Val and Snigova Koroleva, respectively ( $\operatorname{LSD}_{05}$ is $0.43 \mathrm{t} / \mathrm{ha}$ ).

On average for three years of the research, the highest levels of yield 7.00, 6.92, 6.91 and $6.89 \mathrm{t} / \mathrm{ha}$ were provided by the varieties Aivengo, Snigova Koroleva, Deviatyi Val and Akademichnyi. The lowest yield of grain of $6.16 \mathrm{t} / \mathrm{ha}$ was harvested on the variety Dostoinyi, which was mostly infested by the pathogens of fungal leave diseases among all the studied varieties.

\section{CONCLUSIONS}

1. It was determined that in the conditions of irrigation the greatest infestation of winter wheat is caused by such fungal diseases of leaves and stems as: septoriosis (Septoria tritici Desm.), pyrenophorosis (Drechslera tritici-repentis Died.), powdery mildew (Blumeria graminis (DC) Speer.) and yellow rust (Puccinia striiformis). However, in all the years of the research, the plants of winter wheat were infested by septoriosis ( $S$. Tritici Desm.), while other diseases were only in certain years.

2. It was determined that on the natural background of infection all the studied in the conditions of irrigation varieties of winter wheat were infested with fungal diseases in different degrees. The varieties Konka and Anatoliya were the most resistant to the causative agent of septoriosis (S. Tritici Desm.), Maria and Burgunka - to pyrenophorosis (D. Tritici-repentis Died), 
Ovidii, Ledia and Anatoliya - to powdery mildew (B. Graminis), Konka, Maria and Ledia - to yellow rust ( $P$. Striiformis).

3. It was established that in all the years of the research the plants of winter barley varieties were infested with net blotch (Drechslera teres 1to), while the other fungal diseases (Rhynchosporium graminicola Heinsen), powdery mildew (Blumeria graminis Speer) and yellow rust (Puccinia striiformis West) manifested only in certain years.

4. In the conditions of irrigation the varieties Deviatyi Val and Burevii are the most resistant to net blotch (Drechslera teres 1to); Deviatyi Val - to barley stripe (Drechslera graminea lto); Akademichnyi and Burevii - to rhynchosporosis (Rhynchosporium graminicola Heinsen); Akademichnyi to powdery mildew (Blumeria graminis Speer); Aivengo and Burevii - to yellow rust (Puccinia striiformis West). The variety of alternate type Dostoinyo was not resistant to the above-mentioned pathogens.

\section{SUMMARY}

Taking into account that one of the essential reasons that destabilize the production of grain and deteriorates its quality is a significant infestation of plants by fungal diseases, the determination of the phytosanitary condition of new varieties of winter cereal crops in the conditions of irrigation is especially relevant. It is established that on the plants of winter wheat the largest distribution and development had septoriosis disease (S. Tritici) and it was dependent on the biological characteristics of the variety - 56.9 $70.7 \%$ and $9.7-17.4 \%$, respectively. The least disease infested were the plants of the varieties Konka and Anatoliya, and the most infested one was Ovidii. In the plants of winter barley the manifestation and development of the most widespread pathogens of fungal diseases such as net helmintosporosis ( $D$. teres lto) was also dependent significantly on the characteristics of the variety $-69.5-85.2 \%$ and $12.0-35.5 \%$, respectively. More resistant to this disease were the varieties Deviatyi Val and Burevii, and non-resistant one was Dostoinyi.

\section{REFERENCES}

1. Коваленков В.Г. Усложняющаяся фитосанитарная ситуация требует новых решений. Защита и карантин растений. 2010. 7. С.4-7.

2. Ретьман С. В. Плямистості пшениці в Лісостепу України й концептуальні основи захисту: автореф. дис. на здобуття наук. ст. доктора с.-г. наук: спец. 06.01.11 - «Фітопатологія». К., 2009. 43 с.

3. Судникова В. П. Создание исходного материала для селекции пшеницы на устойчивость к Septoria tritici Rob. et Desm. Пути решения 
проблем повышения адаптивности, продуктивности и качества зерновых и кормовых культур: Материалы междунар. практич. конф. Самара, 2003. С. 103.

4. Samobor V. Effect of powdery mildew attack on guality parameters and experimental bread baking of wheat. Acta agriculturae Slovenica. 2006. B. 87, № 2. P. 381-391.

5. Бублик Л.І., Васечко Г.І., Васильєв В.П. та ін. Довідник із захисту рослин. За ред. М.П. Лісового. Київ: Урожай, 1999. 744 с.

6. Агрометеорологічний бюлетень по території Херсонської області за першу, другу і третю декади вересня, жовтня і листопада 2015 p. № №25-33. URL: http://khersonpogoda.ks.ua.

7. Агрометеорологічний бюлетень по території Херсонської області за 2016, 2017 i 2018 pp. № № 1-33. Режим доступ URL: http://khersonpogoda.ks.ua.

8. Заєць С.О., Коваленко О.А., Василенко Р.М. та ін. Ресурсозберігаючі екологічно безпечні технології вирощування озимих зернових культур, сої і кукурудзи на зрошуваних землях півдня України. Наукові основи адаптації систем землеробства до змін клімату в Південному Степу України: монографія; за наук. ред. чл.-кор. НААН Р. А. Вожегової. Херсон: ОЛДІ-ПЛЮС, 2018. С. 500-574.

9. Біловус Г.Я. Плямистості ячменю та заходи 3 обмеження їх розвитку в умовах Лісостепу України: автореф. дис. на здобуття наук ступеня канд. с.-г. наук: спец. 06.01.11 «Фітопатологія». К., 2006. 19 с.

10. Ковальский И.Д., Унтила И.П., Рожкован В.В., Караджова Л.В. Доноры устойчивости ярового ячменя к болезням в условиях Молдавской ССР. Съезд генетиков и селекционеров Молдавии. Кишинев: Штиинца, 1981. С. 81-82.

11. Кузнецова Т.Е. Селекция ячменя на устойчивость к болезням. Краснодар, 2006. 288 с.

\section{Information about the author: \\ Zaiets S. O.,}

Candidate (Ph.D.) of Agricultural Sciences, Senior Researcher, Head of the Department of Agrotechnologies,

Institute of Irrigated Agriculture of the National Academy of Agrarian Sciences of Ukraine Kherson, Naddnipryanske, 73483, Ukraine 
Publishing house "Liha-Pres"

9 Kastelivka str., Lviv, 79012, Ukraine

44 Lubicka str., Toruń, 87-100, Poland

Printed by the publishing house "Liha-Pres"

Passed for printing: September 17, 2019.

A run of 150 copies. 